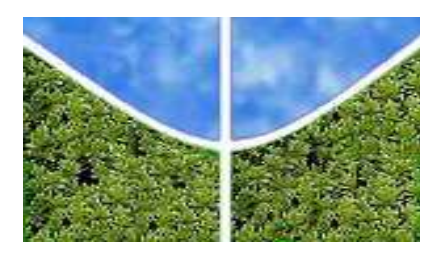

Universidade de Brasília - UNB

Instituto de Ciências Humanas - IH

Departamento de Geografia - GEA

Centro de Cartografia Aplicada e Informação Geográfica - CIGA Programa de Pós-Graduação em Geografia

\author{
UNIVERSIDADE DE BRASÍLIA \\ PÓS-GRADUAÇÃO EM GEOGRAFIA
}

\title{
CONFLITOS SOCIOAMBIENTAIS NA DINÂMICA DO USO DO TERRITÓRIO NA SUB-BACIA DO CÓRREGO CHAPADINHA/BRAZLÂNDIA/DF.
}


UNIVERSIDADE DE BRASÍLIA

CENTRO DE CARTOGRAFIA APLICADA E INFORMAÇÃO GEOGRÁFICA - CIGA PÓS-GRADUAÇÃO EM GEOGRAFIA

\title{
CONFLITOS SOCIOAMBIENTAIS NA DINÂMICA DO USO DO TERRITÓRIO NA SUB-BACIA DO CÓRREGO CHAPADINHA/BRAZLÂNDIA/DF.
}

\author{
Gilney de Araújo Costa
}

Dissertação de Mestrado apresentada ao Departamento de Geografia, Universidade de Brasília, como requisito necessário à obtenção do Título de Mestre em Gestão Ambiental e Territorial.

Orientador: Prof. Dr. Rafael Sanzio Araújo dos Anjos

Dissertação de Mestrado

Brasília-DF, maio de 2015. 


\title{
CONFLITOS SOCIOAMBIENTAIS NA DINÂMICA DO USO DO TERRITÓRIO NA SUB-BACIA DO CÓRREGO CHAPADINHA/BRAZLÂNDIA/DF.
}

\author{
Gilney de Araújo Costa
}

Dissertação de Mestrado submetida ao Departamento de Geografia da Universidade de Brasília como parte dos requisitos necessários à obtenção do Grau de Mestre em Geografia, área de concentração Gestão Ambiental e Territorial, opção Acadêmica.

Aprovado por:

Rafael Sanzio Araújo dos Anjos, Doutor (GEA/UNB).

(Orientador)

Cristina Maria Costa Leite, Doutora (FE/UNB).

(Examinadora Interna)

Patrícia Lustosa Brito, Doutora (POLI/UFBA).

(Examinadora Externa)

Brasília-DF, maio 2015. 
COSTA, GILNEY DE ARAÚJO.

Conflitos Socioambientais na Dinâmica do Uso do Território na Sub-Bacia do Córrego Chapadinha/Brazlândia/DF, 159 p., 297 mm, (UNB-POSGEA, Mestre, Gestão Ambiental e Territorial, 2015).

Dissertação de Mestrado - Universidade de Brasília. Departamento de Geografia.

1. Conflitos Socioambientais $\quad$ 2. Dinâmica do Uso do Território

3. Unidade de Conservação 4. Território da Sub-Bacia do Córrego Chapadinha

É concedida à Universidade de Brasília permissão para reproduzir cópias desta dissertação e emprestar ou vender tais cópias somente para propósitos acadêmicos e científicos. Ao autor reservam-se outros direitos de publicação. Nenhuma parte desta dissertação pode ser reproduzida sem a autorização por escrito do autor.

Gilney de Araújo Costa 
"O que importa na vida não é o simples fato de ter vivido. A diferença que fizemos na vida dos outros que vai determinar a importância da vida que conduzimos".

Nelson Mandela

Dedico a todos os Madibas que lutaram e aos que lutam por uma humanidade justa com igualdade de oportunidade. 


\section{AGRADECIMENTOS}

Agradeço a todos que contribuíram de maneira efetiva para a realização deste trabalho, especialmente, a minha esposa, Andréia Maria dos Santos; e a minha princesa, Ingrid Naielly dos Santos Costa, companheiras de todas as horas.

A minha mãe, Margarida Joaquim de Araújo Costa $\uparrow$.

Ao meu pai, João Pereira da Costa, meu grande amigo e eterno parceiro, sempre presente em todos os momentos de minha vida.

Aos meus irmãos, Gilda de Araújo Costa, Odete de Araújo Costa, Giselle Rodrigues da Costa e Renan Rodrigues da Costa; e aos meus poucos e fiéis amigos, Maria Aparecida de Jesus, Maria de Fátima Rodrigues da Costa, Maria José da Silva, Maurício José da Silva, José Geraldo Neto, Carlos Alberto dos Santos, Paulo César da Silva, Mábia Sousa de Jesus, Daniela de Abreu Reis e Nelson Araújo pelo companheirismo e incentivo para superar meus limites.

A Vânia Lúcia Costa Alves Souza, doutoranda em Geografia na UNB, por esses dois anos de convivência, em que me ajudou a superar as dificuldades com incentivo.

Ao camarada Gilvan Gomes da Silva, doutorando em Sociologia na UNB, por me fazer acreditar que era possível ingressar no mestrado, mesmo diante das adversidades.

Ao Marcus Fábio Ribeiro Farias, doutorando em Geografia na UNB, pelo auxílio na composição dos mapas temáticos.

Especial agradecimento ao meu orientador, Professor Doutor Rafael Sanzio Araújo dos Anjos, pela sua atenção, paciência e, principalmente, pelo suporte teórico e metodológico.

Agradeço, também, aos meus colegas de curso.

A todos o meu muito obrigado. 


\section{RESUMO}

A ocupação do território no Distrito Federal se intensificou a partir da década de 1980, por meio de invasões para habitação e para a produção agrícola. Esse processo desencadeou inúmeros conflitos socioambientais, ocasionando problemas de gestão e na dinâmica territorial. Nesse contexto, a presente pesquisa objetiva analisar os conflitos socioambientais e as suas influências na dinâmica do uso do território na Sub-bacia do Córrego Chapadinha em Brazlândia no DF. Para tanto, realizou-se a pesquisa de campo para a verificação e a análise da estruturação dos conflitos. Na sequência, para demonstrar as influências dos conflitos na dinâmica do uso do território, realizou-se o mapeamento nos seguintes momentos históricos: 1984, 1994, 2004 e 2011, com utilização de imagens de satélite e Sistema de Informação Geográfica. A análise dos conflitos foi realizada com base nas propostas de Little (2001) e Nascimento (2001); considerando a contextualização geográfica, ambiental e histórica com identificação dos atores, dos interesses e da natureza. Dessa forma, o estudo identificou quatro conflitos: três em áreas rurais e um em área urbana. Os conflitos das áreas rurais situam-se em unidades de conservação de uso sustentável, onde o embate maior em dois deles - Floresta Nacional de Brasília e Parque Ecológico Veredinha - é a desapropriação dos imóveis. O terceiro está relacionado ao contrato de uso e concessão de imóvel rural entre os moradores do Assentamento Bela Vista e a Agência de Desenvolvimento do DF. O conflito na área urbana está associado à regularização fundiária. Quanto ao mapeamento, observou-se o aumento das classes antropizadas em detrimento das classes de vegetação. Em 1984, a Área Urbana com Alta Densidade e a Cultura ocupavam 423,11 hectares, enquanto que as classes Mata de Galeria, Reflorestamento, Pastagem, Cerrado e Campo limpo representavam 1890,45 hectares. Em 2011, as classes antropizadas possuíam a extensão de 1434,65 hectares, por sua vez as classes com vegetação ocupavam 880,32 hectares. Conclui-se que os conflitos estruturaram-se por meio de invasões, às margens das legislações urbanísticas e ambientais, de terras públicas, sem qualquer controle inicial do Poder Público. Por fim, a pesquisa conduziu às seguintes recomendações: nas áreas rurais os moradores devem articular com o Poder Público, a partir do diálogo e da cooperação, a formulação de mecanismos legítimos para resolução dos conflitos; e, nas áreas urbanas, o Governo do DF deve promover a regularização fundiária com base nas Áreas de Regularização de Interesse Social.

Palavras-Chave: Conflitos Socioambientais; Território da Sub-bacia do Córrego Chapadinha; Dinâmica do Uso do Território; Unidade de Conservação. 


\begin{abstract}
The occupation of the territory of the Federal District has intensified from the 1980s though land invasions for housing and agricultural production. This process has triggered countless socio-environmental conflicts, leading to management and territorial dynamics problems. Within this context, this study aims to analyze the socio-environmental conflicts and their influence on the land use of the Córrego Chapadinha sub-basin in Brazlandia, DF. To this end, a field study was carried out to investigate and analyze the structure of the conflicts. Next, in order to demonstrate the influence of the conflicts on land use dynamics, a mapping of the following historical moments was made using satellite imaging and GIS: 1984, 1994, 2004, and 2011. The conflict analysis was based on the proposals of Little (2001) e Nascimento (2001), considering the geographical, environmental and historical context with the identification of the actors, the strategies and the nature of the conflicts. The study identified four conflicts: three in rural areas and one in an urban area. The conflicts in the rural areas took place in sustainable use conservation units, where the greatest dispute in two of them - Brasília National Forest and the Veredinha Ecological Park - is the expropriation of the properties. The third is related to the concession and land use contract of rural properties between the residents of the Bela Vista Settlement and the Development Agency of the Federal District. The conflict in the urban area is associated with land tenure. With regard to the mapping, an increase was observed in the anthropic classes at the expense of vegetation classes. In 1984 high density urban areas and crops occupied 423.11 hectares, while the gallery forest, reforestation, pasture, Cerrado and clean field classes represented 1,890.45 hectares. In 2011 the anthropic classes extended over 1,434.65 hectares, while classes with vegetation covered 880.32 hectares. One can conclude that the conflicts were structured through invasions of public land, outside the urban and environmental laws, with no initial control of public authorities. Finally, the study led to the following recommendations: in the rural area inhabitants should seek public authorities for the formulation, through dialogue and cooperation, of legitimate mechanisms for conflict resolution; in urban areas, the government of the Distrito Federal should promote tenure regularization based on the Social Interest Regularization Areas.
\end{abstract}

Keywords: Socio-environmental Conflicts; Córrego Chapadinha sub-basin Territory; Land Use Dynamics; Conservation Unit. 


\section{LISTA DE FIGURAS}

FIGURA 01 Estrutura Metodológica da Pesquisa no Território da Sub-Bacia do Córrego Chapadinha.

FIGURA 02

Plano Piloto de Brasília.

FIGURA 03

Uso do Território e Área com Restrições Físico-Ambientais no DF.

Mapa de Localização da Sub-Bacia do Córrego Chapadinha/Brazlândia/DF.

FIGURA 05

Localização da Região Administrativa de Brazlândia - RA IV e do Sítio Urbano de Brazlândia.

FIGURA 06

Imagem de Localização da APA da Bacia do Rio Descoberto.

FIGURA 07

Localização do Parque Ecológico Veredinha/Brazlândia/DF.

FIGURA 08

Moradia no Início do Assentamento Bela Vista em 1996, com Lona e Madeirites.

FIGURA 09

Cristovam Buarque e o Presidente da Cooperativa, Construção de Residência em um Beco de Brazlândia.

FIGURA 10

Imagem de Localização da Floresta Nacional de Brasília.

FIGURA 11

Invasão na Quadra 55 no Novo Assentamento, Antes do Incêndio, e depois do Incêndio, e Estruturação das Quadras 33 e 34 da Vila São José Brazlândia/DF.

FIGURA 12 Imagem dos Principais Conflitos Socioambientais no Território da Sub-Bacia do Córrego Chapadinha/Brazlândia/DF.

FIGURA 13 Mapas do Uso do Território da Sub-Bacia do Córrego Chapadinha DF -1984, 1994,2004 e 2011.

FIGURA 14 Mapa de Uso do Território do Parque Ecológico Veredinha.

FIGURA 15

Localização do Assentamento Maranata e do Setor Capãozinho.

Construção de Madeirite e Via sem Iluminação Pública no Assentamento Maranata.

FIGURA 17

Mapa do Zoneamento da APA da Bacia do Rio Descoberto.

FIGURA 18 Construção de Alvenaria e Via com Iluminação Pública no Assentamento Bela Vista.

FIGURA 19

Local de Depósito de Lixo no Assentamento Bela Vista.

FIGURA 20

Mapa de Estratégias de Regularização Fundiária e de Ofertas de Habitacionais

FIGURA 21 Parque Ecológico Veredinha, Quadras 33 e 34 e Bacias de Contenção. 


\section{LISTA DE GRÁFICOS}

GRÁFICO 01 Evolução da Área Urbana Total do Distrito Federal (hectares): 19642010 .

GRÁFICO 02 Variação da Mata de Galeria no Território da Sub-Bacia do Córrego Chapadinha (hectares). 1984-2011.

GRÁFICO 03 Variação do Reflorestamento no Território da Sub-Bacia do Córrego Chapadinha (hectares). 1984-2011

GRÁFICO 04 Variação da Área Urbana com Alta Densidade no Território da SubBacia do Córrego Chapadinha (hectares). 1984-2011.

GRÁFICO 05 Variação da Pastagem no Território da Sub-Bacia do Córrego Chapadinha (hectares) 1984-2011

GRÁFICO 06 Variação do Cerrado no Território da Sub-Bacia do Córrego Chapadinha (hectares). 1984-2011.

GRÁFICO 07 Variação do Campo Limpo no Território da Sub-Bacia do Córrego Chapadinha (hectares). 1984-2011

GRÁFICO 08 Variação da Cultura no Território da Sub-Bacia do Córrego Chapadinha (hectares). 1984-2011....

GRÁFICO 09 Variação dos Lagos no Território da Sub-Bacia do Córrego Chapadinha (hectares). 1984-2011.

GRÁFICO 10 Valor Relativo Potencial de Algumas Categorias de Unidades de Conservação Brasileiras com a Finalidade de Preservar a Biodiversidade. 


\section{LISTA DE QUADROS}

QUADRO 01 Categorias de Unidades de Conservação do Brasil................................. 31

QUADRO 02 Categorias de Unidades de Conservação do Distrito Federal.................. 31

QUADRO 03 Características das Imagens Selecionadas.......................................... 45

QUADRO 04 Lei e Data de Criação das Regiões Administrativas do Distrito

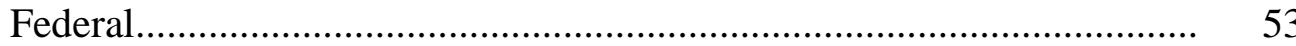

QUADRO 05 Operações do Comitê de Combate ao Uso Irregular do Solo do DF em Áreas Públicas Rurais, em 2013............................................................. 66

QUADRO 06 Crescimento das Ocupações Irregulares no DF....................................... 67

QUADRO 07 Matriz Síntese de Caracterização dos Atores dos Principais Conflitos Socioambientais Identificados............................................................. 98

QUADRO 08 Moradores do Parque, Organizados segundo os Locais e o Tempo de Ocupação.

QUADRO 09 Recomendações (Parque EcológicoVeredinha)...................................... 131

QUADRO 10 Recomendações (APA da Bacia do Rio Descoberto)............................. 132

QUADRO 11 Recomendações (Floresta Nacional de Brasília).................................... 133 


\section{LISTA DE TABELAS}

TABELA 01 Evolução da População do Distrito Federal, Taxa Média Geométrica de Crescimento Anual e Densidade Demográfica (1957/2010).

TABELA 02 Quantificação das Classes do Uso do Território na Sub-Bacia do Córrego Chapadinha (hectares) e (\%). 1984-2011................................................. 84 


\section{LISTA DE ABREVIATURAS E SIGLAS}

APAs

ARIS

CAESB

CEB

CODHAB

CODEPLAN

DF

EMBRAPA

EUA

FUNATURA

GDF

IBAMA

IBRAM

ICMBio

INPE

$\mathbf{K m}^{2}$

MMA

MPDFT

NOVACAP

PDOT

PEOT

POT

POUSO
Áreas de Proteção Ambiental

Áreas de Regularização de Interesse Social

Companhia de Saneamento Ambiental

Companhia Energética de Brasília

Companhia de Desenvolvimento Habitacional do Distrito Federal

Companhia de Planejamento do Distrito Federal

Distrito Federal

Empresa Brasileira de Pesquisa Agropecuária

Estados Unidos da América

Fundação Pró-Natureza

Governo do Distrito Federal

Instituto Brasileiro do Meio Ambiente e Recursos Naturais Renováveis

Instituto Brasília Ambiental

Instituto Chico Mendes de Conservação da Biodiversidade

Instituto Nacional de Pesquisa Espacial

Quilômetro Quadrado

Ministério do Meio Ambiente

Ministério Público do Distrito Federal e Territórios

Companhia Urbanizadora da Nova Capital

Plano Diretor de Ordenamento Territorial

Plano Estrutural de Ordenamento Territorial

Plano de Ocupação Territorial

Plano de Ocupação e Uso do Solo 


$\begin{array}{ll}\text { RA } & \text { Região Administrativa } \\ \text { SDUC } & \text { Sistema Distrital de Unidade de Conservação da Natureza } \\ \text { SEDUMA } & \text { Secretaria de Estado e Desenvolvimento Urbano e Meio Ambiente } \\ \text { SIG } & \text { Sistema de Informação Geográfica } \\ \text { SNUC } & \text { Sistema Nacional de Unidades de Conservação da Natureza } \\ \text { SR } & \text { Sensoriamento Remoto } \\ \text { TAC } & \text { Termo de Ajustamento de Conduta } \\ \text { TERRACAP } & \text { Agência de Desenvolvimento do Distrito Federal } \\ \text { UICN } & \text { União Internacional para Conservação da Natureza } \\ \text { UIPN } & \text { União Internacional para Proteção da Natureza } \\ \text { UNESCO } & \text { United Nations Educational, Scientific and Cultural Organization } \\ \text { ZEIS } & \text { Zonas Especiais de Interesse Social }\end{array}$




\section{SUMÁRIO}

LISTA DE FIGURAS

LISTA DE GRÁFICOS

LISTA DE QUADROS

LISTA DE TABELAS

LISTA DE ABREVIATURAS E SIGLAS

\section{INTRODUÇÃO}

\section{FUNDAMENTAÇÃO TEÓRICA E PROCEDIMENTOS METODOLÓGICOS}

1.1 ÁREAS PROTEGIDAS: IDEIAS E EVOLUÇÕES........................................................22

1.2 CONCEITO DE UNIDADE DE CONSERVAÇÃO.........................................................27

1.2.1 UNIDADES DE CONSERVAÇÃO NO BRASIL E NO DISTRITO FEDERAL..........28

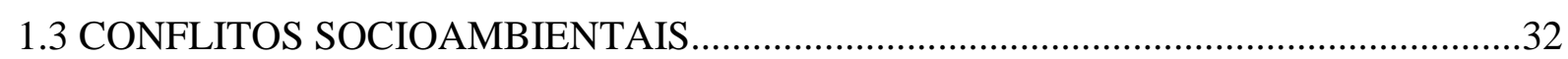

1.4 USO DO TERRITÓRIO: CONCEITO E MAPEAMENTO_..............................................39

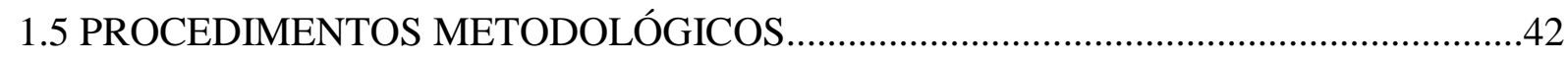

1.5.1 CARACTERIZAÇÃO DA PESQUISA...................................................................42

1.5.2 PROCEDIMENTOS DE COLETA E DE ANÁLISE DOS DADOS..............................43

2 USO E OCUPAÇÃO DO TERRITÓRIO NO DISTRITO FEDERAL - SÍNTESE

2.1 USO E OCUPAÇÃO DO TERRITÓRIO DO DISTRITO FEDERAL...............................49

2.2 PLANOS DE OCUPAÇÃO E ORDENAMENTO TERRITORIAL ....................................58

3 SUB-BACIA DO CÓRREGO CHAPADINHA: OS CONFLITOS SOCIOAMBIENTAIS E A DINÂMICA DO USO DO TERRITÓRIO

3.1 CARACTERIZAÇÃO DO TERRITÓRIO_.................................................................69

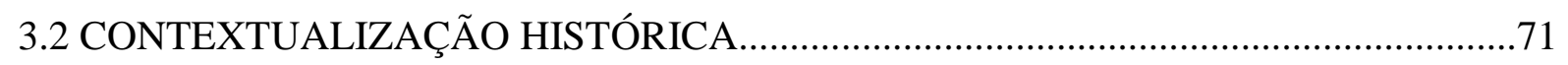

3.3 MAPEAMENTO DA DINÂMICA DO USO DO TERRITÓRIO......................................82

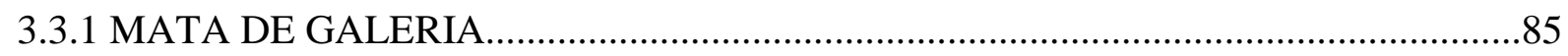

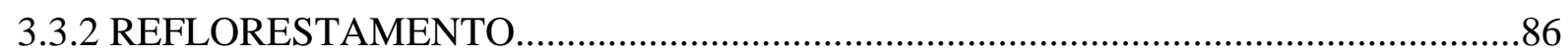

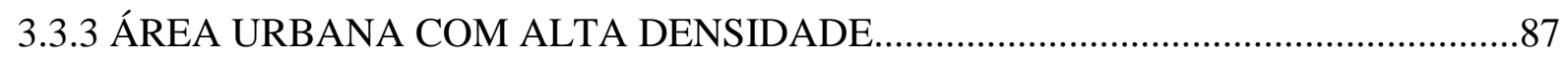

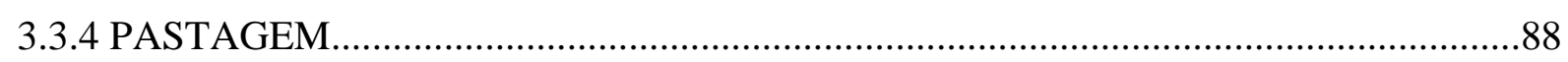

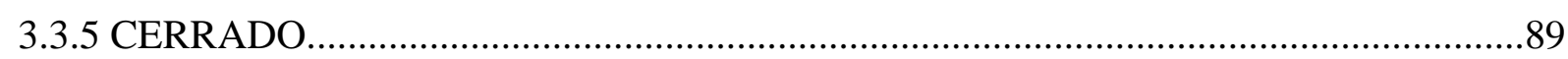

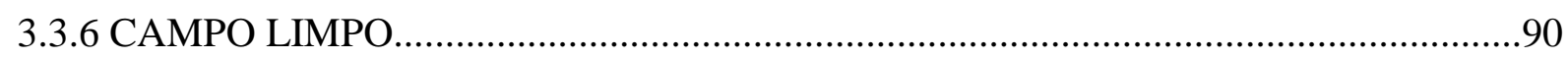

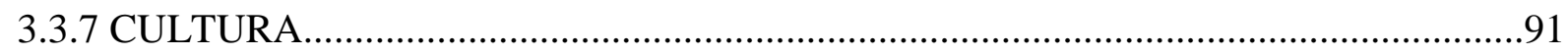

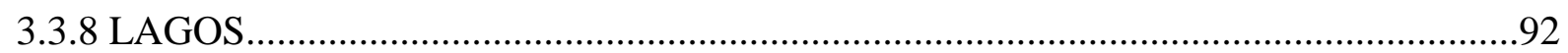

3.4 CARACTERIZAÇÃO DOS ATORES E DE SEUS INTERESSES..................................93 


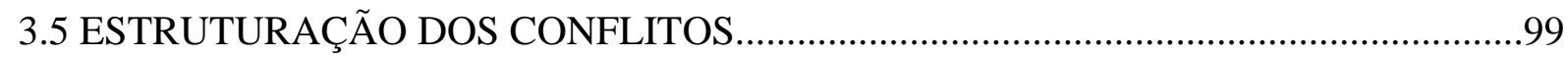

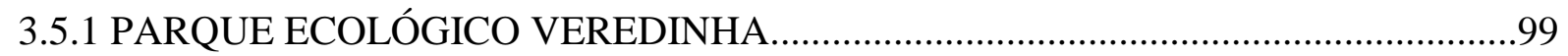

3.5.2 ASSENTAMENTO MARANATA E SETOR CAPÃOZINHO...................................105

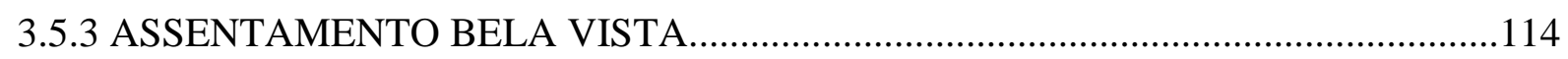

3.5.4 NOVO ASSENTAMENTO, QUADRAS 33 E 34 E LOTES NOS ANTIGOS BECOS.

4 CONCLUSÕES E RECOMENDAÇÕES

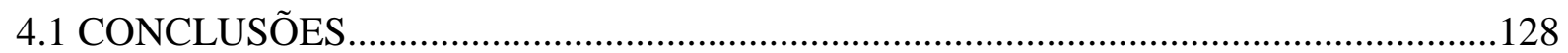

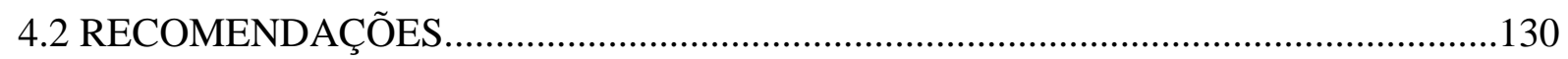

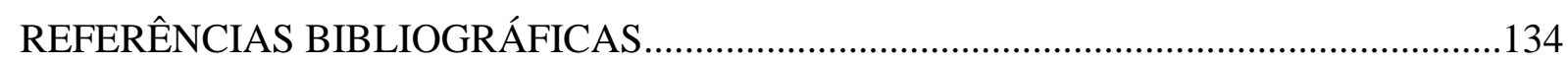

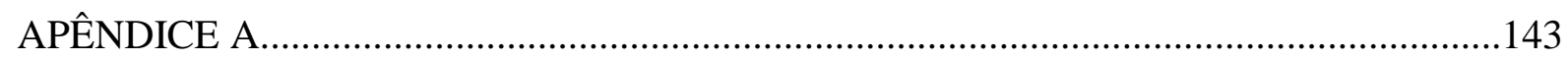

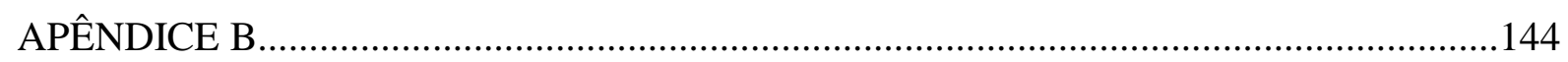

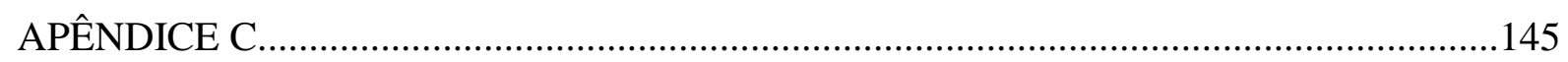

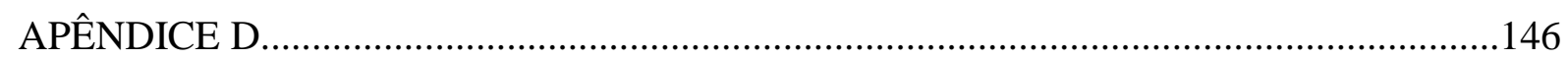

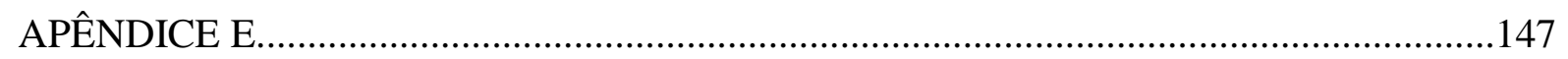

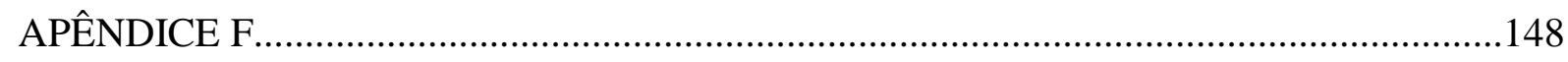

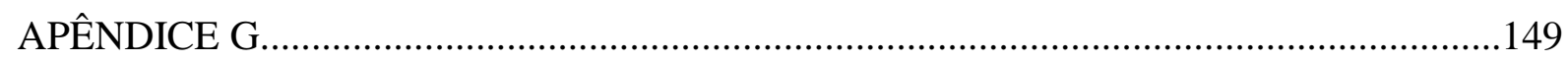

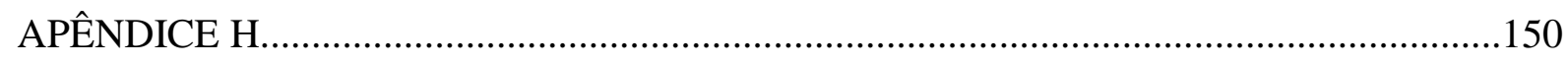

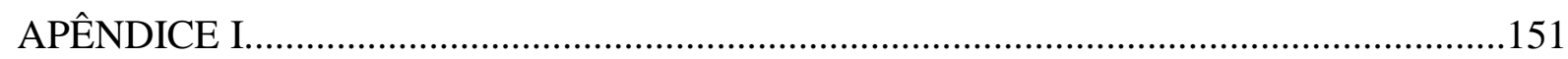

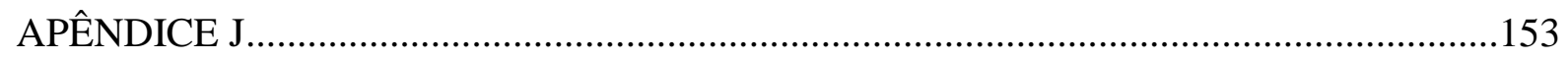

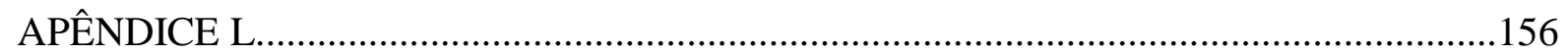




\section{INTRODUÇÃO}

O cerrado brasileiro ocupa uma porção de aproximadamente 1,55 milhões de quilômetros quadrados $\left(\mathrm{Km}^{2}\right)$ do Planalto Central, estendendo-se pelos estados da Bahia, Goiás, Mato Grosso, Mato Grosso do Sul, Maranhão, Minas Gerais, Piauí, Tocantins e Distrito Federal (DUARTE; LEONARDO e THEODORO, 2002).

O Distrito Federal (DF) abrange uma área de mais de 5 mil $\mathrm{Km}^{2}$, tem como vegetação predominante fitofisionomias características do Cerrado brasileiro. Embora rica em biodiversidade, a região é alvo de problemas ambientais relacionados à intensa apropriação do solo (BRAGA; PIRES, 2002). Conforme a pesquisa desenvolvida pela Organização das Nações Unidas para a Educação, a Ciência e a Cultura (UNESCO), de 1954 até 1998 as perdas da vegetação do Cerrado no DF foram de 73,80\%.

É importante mencionar que a degradação da vegetação compromete as bacias hidrográficas. Nesse sentido, além de constituírem-se como unidades de informações hidrológicas, as bacias hidrográficas têm o seu território utilizado para manejo, pois nela se observa a dependência de todos os componentes do crescimento e desenvolvimento da sociedade (ISAÍAS, 2008).

De acordo com Isaías (idem), o DF é rico em nascentes, contudo, possui cursos de água pouco extensos e com vazões modestas. Dessa forma, apesar do grande número de nascentes, os cursos d'água apresentam limitações quanto à quantidade de água disponível para abastecimento.

Nesse sentido, a dinâmica de formação do território no DF está intimamente relacionada aos intensos processos de adensamento da malha urbana e do crescimento da agricultura que, em conjunto, podem ser considerados os principais componentes das modificações territoriais da redução da área de cerrado e pelo comprometimento dos recursos hídricos.

Gonzales (2010) enfatiza que a desordem na forma de expansão urbana e a tendência à deterioração ambiental estão presentes no quadro atual do território do DF. O maior problema é o fato de que, em sua grande maioria, estão localizadas em áreas cujo meio natural tem características mais sensíveis e que ainda desenvolvem atividades de sua vocação original. De acordo com a autora, o meio ambiente natural já apresenta comprometimentos irreversíveis, é grave a expansão irregular e progressiva de áreas residenciais sobre as zonas rurais, principalmente sobre as zonas rurais constituintes de unidades de conservação da natureza. 
Entre as unidades localizadas no DF, estão os Parques Ecológicos, a Floresta Nacional de Brasília e as Áreas de Proteção Ambiental (APAs). As APAs perfazem um total de seis áreas: três federais - APA do Planalto Central, APA da Bacia do Rio Descoberto e APA da Bacia do Rio São Bartolomeu -; e três distritais - APA do Lago Paranoá, APA da Cafuringa e APA Gama e Cabeça de Veado.

Salienta-se que essas unidades nem sempre estão dotadas de infraestruturas e Planos de Manejos adequados para o seu funcionamento. Assim, elas recebem, constantemente, intervenções humanas, por exemplo, as invasões e o parcelamento irregular. Tal fato tem causado inúmeros conflitos socioambientais: conservação versus desenvolvimento socioeconômico.

Segundo Little (2001), o aspecto mais novo da temática - conflitos socioambientais está no retorno do mundo natural como elemento importante nos conflitos atuais, pois, durante séculos, os seres humanos acreditaram na infinidade dos recursos naturais. Contudo o surgimento dos inúmeros problemas ambientais, nas últimas décadas, tais como diminuição da vegetação natural, contaminação das águas e perda de qualidade dos solos entre outros, fez despertar a sensibilidade do ser humano, retirar-lhe a arrogância de se considerar o suprassumo diante da natureza, levando-o a aceitar que os seres humanos são animais com necessidades relativas ao meio ambiente e que são dependentes dele.

Nesse contexto, o retorno da problemática ambiental ressuscitou os velhos temas da sobrevivência humana e das formas de adaptação e os colocou no centro do cenário econômico e político. Dessa forma, a temática dos conflitos socioambientais representa um campo de estudo e, ao mesmo tempo, um campo de ação política (LITTLE, 2001).

Nesse sentido, a pesquisa tem como foco o território da Sub-bacia do Córrego Chapadinha situada na APA da Bacia do Rio Descoberto, em Brazlândia, no DF. Entende-se que, atualmente, o território da Sub-bacia configura uma arena de conflitos socioambientais com o envolvimento de diversos atores com posicionamentos divergentes em torno do seu uso, pois, no final da década de 1980 e início da década de 1990, se tornou objeto de intensa apropriação. Frisa-se que esses embates constituem a tensão entre o desenvolvimento social, econômico e a sustentabilidade ambiental. Diante do exposto, fica evidente a seguinte questão: como se estruturam os conflitos socioambientais e suas influências na dinâmica do uso do território na Sub-bacia do Córrego Chapadinha?

Em consonância com a questão apresentada, o objetivo principal da pesquisa é analisar os conflitos socioambientais e suas influências na dinâmica do uso do território na Sub-bacia 
do Córrego Chapadinha, em Brazlândia, no Distrito Federal. No sentido de atingir o objetivo principal da pesquisa com plenitude, realizam-se outras ações equivalentemente importantes, quais sejam: identificar os principais conflitos socioambientais existentes na área pesquisada; confeccionar mapas temáticos do uso do território em quatro momentos históricos: 1984, 1994, 2004 e 2011; e mensurar as classes temáticas do uso do território.

Assim, à luz das interpretações que revestem o tema, a pesquisa parte da hipótese de que a estruturação dos conflitos socioambientais ocorreu em momento oportuno, às margens das legislações - ambiental e urbanística - com a conivência do Poder Público.

Para atingir o objetivo proposto, esta dissertação está estruturada em quatro capítulos. Os capítulos 1 e 2 dizem respeito ao referencial teórico, essencial para o desenvolvimento da pesquisa. O capítulo 3 revela e analisa os conflitos socioambientais e a influência deles na dinâmica do uso do território. O capítulo 4 traz as conclusões e as recomendações sugeridas, conforme a descrição a seguir:

No capítulo 1 - FUNDAMENTAÇÃO TEÓRICA E PROCEDIMENTOS METODOLÓGICOS - estão abordados os seguintes temas: unidades de conservação, conflitos socioambientais, território e uso do território, temáticas em que se insere a pesquisa. Inicialmente, realiza-se um resgate teórico das discussões que envolvem o modelo que norteou a criação das áreas protegidas no mundo e no Brasil. A seguir, trata sumariamente do processo de formulação do SNUC brasileiro: tema importante para compreensão das unidades de conservação que engloba o território da Sub-bacia do Córrego Chapadinha. Na sequência, discorre-se acerca dos conflitos socioambientais, de forma, a entender os embates que os envolvem. Também, neste capítulo, citam-se diversas pesquisas e os métodos utilizados para o mapeamento da dinâmica do uso do território. Estas pesquisas contribuíram metodologicamente para a elaboração dos mapas temáticos empregados na análise da dinâmica territorial. Enfatiza-se que, no estudo, recorreram-se aos conceitos de unidade de conservação, conflitos socioambientais, território e uso do território para o seu pleno desenvolvimento. Por fim, apresentam-se os procedimentos metodológicos adotados para a produção da pesquisa.

\section{O capítulo 2 - USO E OCUPAÇÃO DO TERRITÓRIO NO DISTRITO FEDERAL -} SÍNTESE - contribui para a compreensão da estruturação dos conflitos socioambientais no território da Sub-bacia do Córrego Chapadinha. Primeiramente, apresentou-se, de maneira sucinta, a quantidade de Regiões Administrativas existentes no DF. Para tal, realizou-se um breve histórico, que começa com o Plano Piloto do arquiteto Lúcio Costa, concretização da 
cidade de Brasília, primeira RA do DF. Na complementação, usam-se informações da Companhia de Desenvolvimento do DF organizadas em um quadro que retrata as trinta e uma regiões do DF. Em seguida, é realizada uma descrição do zoneamento proposto para o DF, nos diversos documentos de ordenamentos. Inicia-se com o primeiro documento de zoneamento do DF, Decreto Federal $\mathrm{n}^{\circ}$ 163/1962, seguido do Plano Estrutural de Ordenamento Territorial (1978), Plano de Ocupação Territorial (1985), Plano de Ocupação e Uso do Solo (1990) e dos Planos Diretores de Ordenamento Territorial de 1992, 1997, 2009 e 2012.

Já no capítulo 3 - SUB-BACIA DO CÓRREGO CHAPADINHA: CONFLITOS SOCIOAMBIENTAIS E A DINÂMICA DO USO DO TERRITÓRIO - apresenta-se a finalidade, de forma sistemática, de descrever a contextualização geográfica, ambiental e histórica do território da Sub-bacia do Córrego Chapadinha. Com isso, revelam-se os conflitos socioambientais mais emblemáticos. Na sequência, no intuito de responder a questão de pesquisa, são analisadas as influências dos conflitos na dinâmica do uso do território em quatro momentos históricos: 1984, 1994, 2004 e 2011. A seguir, identificam-se e caracterizam-se os atores principais envolvidos. Na continuidade, discorre-se acerca da estruturação dos conflitos.

No capítulo 4 - CONCLUSÕES E RECOMENDAÇÕES - retomam-se aspectos relevantes dos capítulos anteriores e apresentam-se as conclusões obtidas por meio da análise dos dados. Durante o processo da pesquisa, verificou-se que a falta de diálogo entre as partes e a falta de comprometimento do Poder Público dificultam a resolução dos conflitos socioambientais. Nesse sentido, como produto final, apresentam-se algumas recomendações, descritas em três quadros, dedicadas a alguns atores identificados nos conflitos socioambientais nas unidades de conservação Parque Ecológico Veredinha, Floresta Nacional de Brasília e APA da Bacia do Rio Descoberto. Salienta-se que, para os conflitos socioambientais localizados no Parque Ecológico Veredinha e na Floresta Nacional de Brasília, as recomendações apontam para a importância de se formularem, a partir do princípio do diálogo e da cooperação, instrumentos e mecanismos legítimos para resolução dos conflitos. Nos conflitos situados na APA da Bacia do Rio Descoberto, as recomendações foram formuladas com ênfase na regularização fundiária nas áreas urbanas conflituosas e na firmação do Contrato de Concessão de Uso Oneroso de Imóvel entre os moradores e a TERRACAP nas áreas rurais pesquisadas. 


\section{CAPÍTULO 1}

FUNDAMENTAÇÃO TEÓRICA E PROCEDIMENTOS METODOLÓGICOS 


\section{FUNDAMENTAÇÃO TEÓRICA E PROCEDIMENTOS METODOLÓGICOS}

Neste capítulo são apresentados os seguintes temas: conservação dos recursos naturais, conflitos socioambientais, território e uso do território, os quais são fundamentais para o desenvolvimento da pesquisa. No decorrer do capítulo, buscam-se sempre os conceitos pertinentes a cada tema. Por fim, apresentam-se os procedimentos metodológicos utilizados no trabalho.

\section{1 ÁREAS PROTEGIDAS: IDEIAS E EVOLUÇÕES}

Como o objeto de pesquisa está situado em unidades de conservação da natureza, procura-se fazer um resgate teórico dessa temática, com exposição dos eventos ocorridos internacionalmente e que influenciaram o desdobramento das ideias de proteção iniciadas no final do século XIX.

A partir do instante em que o homem passou a utilizar os recursos naturais como insumo para a produção de seus bens, a natureza sofre intensa degradação ambiental (COSTA, 2009). A espécie humana está consumindo a natureza de maneira voraz, e essa espécie precisa desesperadamente da natureza que está destruindo (DOUROJEANNI; PÁDUA, 2007). Como consequência da perda dos recursos naturais surgiram ideias para sua proteção.

A necessidade de medidas para preservar uma porção territorial é registrada em muitas culturas em todo o mundo há vários séculos. A ideia de preservação de parcelas da natureza como a fauna e a flora é remota (DORST, 1973).

Davenport e Rao (2002) citam que datam, do século VII A.C., as evidências mais antigas de proteção de recursos naturais. Os autores descrevem que nobres assírios reservavam áreas para a prática de caça e nessas áreas aperfeiçoavam suas técnicas de combate e corridas. Além de reservas criadas para prática de caça, algumas civilizações as criavam com base em concepções religiosas.

Contudo, o marco moderno da proteção de áreas naturais contra os processos destrutivos da ação humana aconteceu nos Estados Unidos (EUA), em meados do século XIX, com a criação de Yellowstone National Park, em 1872 (DORST, 1973). O modelo tem como pressuposto proteger integralmente a natureza ameaçada pelo avanço das novas tecnologias 
urbano industrial. Assim, o ser humano torna-se apenas um contemplador das áreas selvagens (Wilderness). De acordo com Diegues (2000), Wilderness são aquelas áreas que não sofreram a ação humana, ou seja, áreas virgens e de grande beleza cênica, onde o ser humano é visitante e nunca morador e as quais ele deve proteger.

Concomitantemente ao surgimento dos parques, havia nos EUA dois tipos de motivações para atribuir valor e importância à natureza: os preservacionistas e os conservacionistas (FRANCO; SCHITTINI, 2010). As duas visões teóricas do mundo natural foram sistematizadas nas propostas de John Muir (1838-1914), considerado o maior expoente do preservacionismo; e de Gifford Pinchot (1865-1946), o mais reconhecido e bem sucedido conservacionista (DIEGUES, 2000). Muir e Pinchot influenciaram diretamente na instituição das primeiras áreas protegidas, com destaque para as concepções defendidas por John Muir.

Segundo Diegues (2000), Gifford Pinchot age dentro de um contexto de transformação da natureza em mercadoria; cria, dessa forma, um movimento de conservação dos recursos, apregoando o uso racional deles. Na concepção de Pinchot, a natureza é frequentemente lenta e os processos de manejo podem torná-la eficiente. Na visão desse teórico, a conservação deve se basear em três princípios: o uso dos recursos naturais pela geração presente; a prevenção do desperdício; e o uso dos recursos naturais para benefício da maioria dos cidadãos.

Opondo-se aos conservacionistas, estão as concepções preservacionistas, representados por John Muir. Segundo Franco e Schittini (2010), esse movimento defende a proteção da natureza pela criação de áreas nas quais não é permitido nenhum uso humano diferente da simples visitação temporária, são áreas virgens onde se congregam os animais, as plantas, as águas e as rochas.

Todavia a criação desse modelo de proteção provoca conflitos entre os mais variados atores. Como destaca Schaik e Terborgh (2002), por trás de praticamente todos os parques dos EUA, existe uma história de oposição, de protestos, de menosprezo e de pressões políticas. Para ilustrar esse problema, tomemos como exemplo o parque nacional de Yellowstone. Morsello (2001) frisa que, em 1877, cinco anos após a criação do parque, cerca de trezentas pessoas morreram em combates entre tribos locais e a superintendência civil da área. Davenport e Rao (2002) relatam que, vinte anos após a implantação de Yellowstone, deputados de Montana apresentaram projetos junto ao congresso americano para retirar a proteção concedida a esse parque, mas nenhum projeto foi aprovado. 
Por oportuno, frisa-se que a criação de parques exige a remoção dos habitantes a partir de sua instituição legal. Brito (2008) cita, como exemplo, parques fundados no Canadá, Uganda e no Quênia, onde ocorreu a remoção de pescadores artesanais no Canadá, os IK em Uganda e os Maasai no Quênia.

Essas ideias foram disseminadas através dos inúmeros acordos, convenções, congressos e encontros realizados internacionalmente. Os debates contemporâneos acerca da proteção da natureza, desde cedo, ganharam a arena internacional. Isso ocorreu porque havia desafios semelhantes em diferentes países. A pouca experiência sobre o assunto tornava o intercâmbio de conhecimentos importantes. Além disso, os problemas que afetavam o ambiente natural se mostravam cada vez mais globais ou, ao menos, transfronteiriços e não podiam ser enfrentados e resolvidos de maneira fragmentada, como se estivessem limitados unicamente às fronteiras nacionais (FRANCO; SCHITTINI, 2010).

Um exemplo é a Convenção para a Preservação da Fauna e da Flora em Estado Natural, assinada em Londres em 1933. Essa convenção foi ratificada pela maioria dos países do Velho Mundo, que visava restringir as ameaças à vida selvagem africana por meio da criação de parques nacionais (BRITO, 2008). Observa-se que, apesar de tratar da proteção à natureza na África, a convenção foi assinada apenas pelas potências europeias. Por isso, a visão de natureza embutida no texto da convenção reflete principalmente preocupações das pessoas das metrópoles, o que gerou, muitas vezes, a antipatia das populações colonizadas africanas (FRANCO; SCHITTINI, 2010).

Outros encontros ocorreram, nos quais a concepção de proteção total dos recursos naturais sem a presença dos seres humanos firmou-se ainda mais, por exemplo, a Convenção para a Proteção da Flora, da Fauna e das Belezas Cênicas Naturais dos Países da América “Convenção Panamericana", ocorrida em Washington, em 1940. Ela buscou o comprometimento dos países sul-americanos a demarcarem áreas naturais protegidas em seus territórios.

Em 1948 foi criada a União Internacional para Proteção da Natureza (UIPN), cuja missão era garantir que qualquer uso de recursos naturais fosse feito de maneira justa. Salienta-se que, em razão de extinção de várias espécies de plantas, nasce a preocupação com a necessidade de manutenção de habitats em vez de espécies específicas. Isso influenciou até mesmo na mudança de nome de UIPN para União Internacional para Conservação da Natureza (UICN), a partir de 1956. 
No interior da UICN, foi criada, em 1960, a Comissão de Parques Nacionais e Áreas Protegidas, cujo objetivo era a promoção e o monitoramento dos parques nacionais e outras áreas protegidas. A partir dessa comissão vários eventos foram realizados internacionalmente, no sentido de atenuar os conflitos gerados no contexto destas áreas. Como é o caso, por exemplo, dos Congressos Mundiais sobre Parques Nacionais, iniciados em 1962, em Seattle, nos EUA (BRITO, 2008).

Milano et al. (2004) estabelecem uma compreensão a respeito da evolução das preocupações discutidas em diversos Congressos Mundiais sobre Parques. No I Congresso Mundial, discutiu-se o efeito das ações do ser humano sobre a vida silvestre. No II Congresso, realizado em 1972, em Yellowstone, entre os temas tratados, destacaram-se os problemas sociais, científicos e ambientais. Em 1982, no III Congresso, cuja realização deu-se em Bali, tratou-se de temas acerca do papel de áreas protegidas na sustentabilidade da sociedade e acerca da necessidade de um sistema de áreas protegidas para balancear a conservação e o desenvolvimento. Em 1992, o IV Congresso ocorreu em Caracas e discutiu-se a relação entre pessoas e áreas protegidas. Além disso, visou-se o estabelecimento de um plano de ação de Caracas, sintetizando as estratégias de ação para as áreas protegidas na próxima década. A temática do $\mathrm{V}$ Congresso foi a questão dos benefícios dos parques nacionais além das fronteiras, cujos objetivos foram explorar e propor novas estratégias para adaptar as áreas protegidas a um mundo sujeito a rápidas mudanças.

Para os autores, a temática discutida nos congressos teve pesos diferentes ao longo das últimas décadas. Percebe-se, claramente, uma priorização das ações para solucionar os conflitos envolvendo as pessoas que vivem no entorno ou dentro das unidades de proteção da biodiversidade.

Assim, nas décadas de 1960 e 1970, a comunidade internacional começou a voltar os olhos para o crescimento de conflitos que envolviam populações e áreas naturais protegidas, especialmente na África, onde grupos étnicos haviam sido removidos para a implantação de áreas naturais protegidas.

Nesse contexto, Brito et al. (2011) relatam que, em 1972, na capital da Suécia (Estocolmo), realizou-se a Conferência da Organização das Nações Unidas sobre Meio Ambiente e Direitos Humanos. A conferência teve como objetivo avaliar os problemas do meio ambiente global e sugerir ações corretivas, não só do ponto de vista científico, mas, principalmente, do ponto de vista social, político e econômico. Conforme os autores, em Estocolmo, o delineamento teórico dos conflitos ambientais começou a ser vislumbrado de 
forma mais efetiva e, após o evento, a análise dos conflitos ambientais foi fixada, definitivamente, na agenda mundial.

De acordo com Ganem e Viana (2005), a partir da década de 1970, passaram a existir tanto a idealização, quanto a implantação de novas áreas de proteção da natureza visando não só à manutenção da biodiversidade, mas também ao desenvolvimento socioeconômico, com o uso racional dos recursos naturais pelo ser humano. Estas áreas passaram a ser um instrumento de planejamento territorial conciliando a presença humana e a conservação da natureza, assim devem combater os efeitos da degradação ambiental e desempenhar importante papel no desenvolvimento social e econômico, bem como a busca permanente de soluções para os conflitos.

Buscando cumprir o Plano de Caracas 1992, foram pactuadas seis categorias básicas de áreas protegidas que servem como modelo mundial, a saber: Reserva Natural, Parque Nacional, Monumento Natural, Área de Manejo de Habitats/Espécies, Paisagem Terrestre/Marítima e Área Protegida de Recursos Manejados (FRANCO; SCHITTINI, 2010).

Ressalta-se que a Convenção de Caracas recomendou a rejeição do reassentamento das populações tradicionais em outras localidades fora das áreas criadas, os quais eram habitantes e, também, ratificou o direito dos povos indígenas sobre as suas terras. Essas decisões foram tomadas devido ao entendimento de que a eficácia das áreas protegidas depende do apoio dos povos que as habitavam antes de sua instituição como áreas protegidas (ARAÚJO, 2007). Naquela convenção, os países também estabeleceram planos de ação para a criação e gestão de áreas protegidas, contendo objetivos, cronogramas e orçamentos claros. Esses planos foram incorporados à discussão de outra importante Conferência: a Conferência das Nações Unidas para o Meio Ambiente e o Desenvolvimento, denominada Eco 92, que foi realizada no Rio de Janeiro.

Conforme Franco e Schittini (2010), na Eco 92, foi lançada a Convenção sobre Diversidade Biológica, que orienta até hoje as principais políticas de conservação da biodiversidade no mundo. O Art. $8^{\circ}$ reforçou a importância das populações locais e dos povos indígenas para a conservação da natureza, inclusive, a promoção do desenvolvimento sustentável em áreas adjacentes às áreas protegidas.

O desenvolvimento sustentável foi, sem dúvida, um avanço de imensa importância. Pode-se dizer que a noção do termo já é um valor positivo, mesmo que utópico, assim como justiça social, democracia e tantos outros (VEIGA; ZATZ, 2008). 
Para Dourojeanni e Pádua (2007), não existem dúvidas de que a promoção do desenvolvimento sustentável é responsável pela tendência socioambiental de manter ou introduzir habitantes nas unidades de conservação. Ainda de acordo com os autores, o principal problema gerado pelo termo para as unidades de conservação é a possibilidade de se confundi-lo com uma panaceia, acreditando que a sua aplicação resolverá simultaneamente, como uma vareta mágica, os problemas sociais e ambientais.

Para Franco e Schittini (2010), as abordagens que envolvem preservacionistas e conservacionistas focalizam aspectos importantes para a promoção da conservação da biodiversidade e para o uso sustentável dos recursos naturais. Na visão dos autores, as áreas protegidas devem contribuir para a promoção do desenvolvimento sustentável e da inclusão social. Entretanto elas têm um papel urgentíssimo a desempenhar na luta contra a extinção de espécies, a função exercida pelas Wilderness. Trata-se, portanto, de integrá-las em políticas públicas mais amplas, valorizando o conhecimento científico necessário para o processo de criação e manejo dessas áreas.

Conforme visto, o modelo desenvolvido nos EUA virou tendência mundial. No Brasil não foi diferente, em meados do século $\mathrm{XX}$ várias áreas foram criadas e exigiam a desapropriação. Entretanto, a partir da década de 1970 o país discutiu a formulação de um sistema que viabilizasse categorias que atendesse a diversos objetivos. Nesse sentido, nos dois tópicos que se seguem (1.2 e 1.2.1), buscam-se descrever o conceito e o histórico de formação do Sistema de Unidade Nacional de Unidade de Conservação da Natureza, respectivamente.

\subsection{CONCEITO DE UNIDADE DE CONSERVAÇÃO}

Segundo Dourojeanni e Pádua (2007), o Brasil é o único país no mundo que utiliza o termo unidade de conservação para se referir à área protegida. Para os autores, essa exclusividade brasileira não é boa nem ruim, é simplesmente uma mostra da magnitude do problema de nomenclatura.

Constata-se, internacionalmente, que unidade de conservação é sinônimo de área protegida. Conforme o nome indica, uma unidade de conservação é uma área dedicada a conservar a natureza. A expressão equivalente área protegida reflete com a mesma força e clareza que o seu objetivo é a proteção da natureza (DOUROJEANNI; PÁDUA, 2007).

Nesse sentido, Machado (2009) esclarece que as unidades de conservação inserem-se no conceito de área protegida, levando-se em conta a definição de área protegida estabelecida 
no Art. $2^{\circ}$ da Convenção sobre Diversidade Biológica (CDB): "área definida geograficamente, que é destinada, ou regulamentada, e administrada para alcançar objetivos específicos de conservação” (CDB apud MACHADO, 2009).

No Brasil, o conceito utilizado é mais abrangente e é estabelecido pelo Sistema Nacional de Unidade de Conservação (SNUC), em seu Art. $2^{\circ}$, inciso I preconiza que:

\footnotetext{
"Unidade de Conservação é o espaço territorial e seus recursos ambientais, incluindo as águas jurisdicionais, com características naturais relevantes, legalmente instituído pelo Poder Público, com objetivos de conservação e limites definidos, sob regime especial de administração, ao qual se aplicam garantias adequadas de proteção".
}

Dourojeanni e Pádua (2007) explicam que o Brasil adotou a palavra conservação em vez de proteção em razão da introdução de novas concepções quanto à proteção. Na primeira metade do século passado, praticamente as únicas áreas eram parques nacionais e reservas de faunas, que refletiam o preservacionismo do século XIX. Essas ideias permearam o globo. Contudo, a partir da década de 1960, as discussões em torno da presença humana fizeram emergir novos ideais, principalmente os conceitos baseados no desenvolvimento sustentável e no socioambientalismo emergente (DOUROJEANNI; PÁDUA, 2007).

Destarte o conceito de unidades de conservação descrito no SNUC engloba as áreas destinadas à conservação tanto públicas quanto privadas e se dividem em dois grupos, com características específicas: Unidades de Proteção Integral e Unidades de Uso Sustentável.

Para maiores esclarecimentos, no tópico que se segue, é apresentado um breve histórico que retrata os caminhos trilhados até a sanção presidencial, em 2000, que instituiu definitivamente o SNUC.

\subsubsection{UNIDADES DE CONSERVAÇÃO NO BRASIL E NO DISTRITO FEDERAL}

No Brasil, as concepções do preservacionismo de John Muir influenciaram diretamente as criações das primeiras áreas protegidas, que foram os parques nacionais. Franco e Schittini (2010) relatam que, quatro anos após a criação do Yellowstone National Park, em 1872, surgiu a primeira proposta para instituição de parques nacionais no Brasil. O Engenheiro e político André Rebouças propôs a criação de um parque na Ilha do Bananal e outro em Sete Quedas. Porém nenhum desses parques foi criado. Os autores enfatizam que a 
justificativa de André Rebouças não era o papel inspirador, baseava-se numa potencialidade econômica orientada ao desenvolvimento do turismo, atividade bastante recente à época, que aparecia como motivação principal.

Na década de 1930, houve avanços em relação à institucionalização de algumas propostas referentes à proteção da natureza e, neste contexto, surgiu o primeiro Código Florestal, instituído pelo Decreto Federal no 23.793/1934. O código definiu que florestas nativas eram consideradas de interesse comum a todos os habitantes do Brasil e, sobre elas, deve haver limitações aos direitos de propriedade. Naquele mesmo ano, foi formulada a nova Constituição, que estabeleceu, como competência da União e dos Estados, a proteção das belezas naturais. Paralelo a esses eventos, foram criados os primeiros parques nacionais brasileiros (FRANCO; SCHITTINI, 2010).

O primeiro parque nacional brasileiro, Itatiaia, foi instituído em 1937, no Rio de Janeiro. Conforme Pádua (1997), a partir da criação do parque Itatiaia até meados da década de 1970, foram estabelecidos vários parques nacionais, tais como o de Iguaçu, no Paraná e o de Serra dos Órgãos, no Rio de Janeiro, ambos em 1939; o de Paulo Afonso, em 1948, na Bahia; o de Aparados da Serra, no Rio Grande do Sul; o do Araguaia, em Goiás; e o de Ubajara, no Ceará, todos em 1959; o das Emas e o de Chapada dos Veadeiros, em Goiás; o de Brasília, no DF e o de Sete Quedas, no Paraná, em 1961; o da Serra da Bocaina, em 1971, no Rio de Janeiro; o da Serra da Canastra, em 1972, em Minas Gerais; e, em 1974, instituiu-se o primeiro parque nacional na Amazônia brasileira, o Parque Nacional da Amazônia.

A implantação efetiva dessa política e a ampliação das áreas protegidas foram, inicialmente, lentas atingindo na década de 1980 um pico com a inclusão de mais de 20 milhões de hectares de novas áreas. Segundo Franco e Schittini (2010), na década de 1990, a taxa de ampliação caiu, contudo, entre os anos 2000 e 2005, outros novos 20 milhões de hectares surgiram como unidades de conservação.

Ressalta-se que a instituição dos primeiros parques nacionais brasileiros visava à conservação da paisagem, pois recepcionava a Constituição Federal de 1937, que orientava resguardar porções do território nacional que tivessem valor estético. Conforme Mercadante (2001), a criação das primeiras áreas protegidas no Brasil não obedeceu a planejamento. Muitas vezes, o estabelecimento foi por motivo político ou por razões estéticas. Não existia uma política com finalidade específica para assegurar a representatividade dos ecossistemas e nem promover um sistema composto por diferentes tipos de categorias com manejo e gestão 
de forma integrada. Contudo, na década de 1970, amadurece-se a ideia de tornar o processo de criação de áreas protegidas mais eficaz, sob a obediência de critérios técnicos.

No intuito de promover um sistema de conservação, em 1976, surgiu o documento que orientou a elaboração do Plano do Sistema de Unidades de Conservação do Brasil. A primeira e a segunda etapas foram publicadas em 1979 e 1982, respectivamente. Pádua (1997) salienta que, em 1976, foi elaborado o documento "Uma Análise de Prioridades em Conservação da natureza na Amazônia”, que norteou a preparação da primeira e da segunda etapa do Plano do Sistema de Unidades de Conservação do Brasil. Esse plano resultou em um expressivo aumento do número de unidades de conservação e da área coberta por elas. Além do conhecimento científico aplicado, o sucesso do plano pode ser atribuído à capacidade de seus proponentes de associar astutamente a conservação aos discursos de desenvolvimento e de progresso vigentes na época.

Conforme Diegues (2000), em 1989, o governo propôs a reavaliação do plano de 1976 e foi encarregada à Fundação Pró-Natureza (FUNATURA) a responsabilidade de organizar as diferentes categorias de unidades de conservação existentes na legislação brasileira em um sistema o SNUC. O SNUC foi concebido para definir critérios mais objetivos para o processo de criação e gestão de diversas categorias de áreas protegidas, de forma a torná-lo mais abrangente e eficaz (FRANCO; SCHITTINI, 2010).

Finalmente, em julho de 2000, com a sanção do presidente da República, foi instituída a Lei $n^{\circ}$ 9.985, que cria o Sistema Nacional de Unidades de Conservação da Natureza. O Art. $3^{\circ}$ reza que o SNUC "é constituído pelo conjunto das unidades de conservação federais, estaduais e municipais (...)”. O Art. $4^{\circ}$ apresenta os objetivos. Entre eles destacam-se os incisos I, II, IV e VI, que correspondem a manter a diversidade biológica; proteger as espécies ameaçadas de extinção; promover o desenvolvimento sustentável, a partir dos recursos naturais; e proteger paisagens naturais e pouco alteradas de notável beleza cênica, respectivamente. $\mathrm{O}$ Art. $7^{\circ}$ descreve que as unidades de conservação dividem-se em dois grupos: proteção integral e uso sustentável. Nota-se no Quadro 01, que o SNUC ratificou duas categorias propostas pela UICN citadas anteriormente (Monumento Natural e Parque Nacional). 
Quadro 01 - Categorias de Unidades de Conservação do Brasil.

\begin{tabular}{l|l}
\hline UNIDADES DE PROTEÇÃO INTEGRAL & UNIDADES DE USO SUSTENTÁVEL \\
\hline Estação Ecológica & Área de Proteção Ambiental \\
\hline Reserva Biológica & Área de Relevante Interesse Ecológico \\
\hline Parque Nacional & Floresta Nacional \\
\hline Monumento Natural & Reserva Extrativista \\
\hline Refúgio de Vida Silvestre & Reserva de Fauna \\
\hline \multirow{2}{*}{} & Reserva de Desenvolvimento Sustentável \\
\cline { 2 - 2 } & Reserva Particular do Patrimônio Natural \\
\cline { 2 - 2 } &
\end{tabular}

Fonte: Art. $7^{\circ}$ e $8^{\circ}$ da Lei Federal no $9.985 / 2000-$ SNUC

No DF, a preocupação com a temática ambiental resultou, numa primeira instância, após o planejamento de Brasília, na criação, em 1961, do Parque Nacional de Brasília, dando partida ao processo de criação de uma série de unidades de conservação (BARRETO; GIUSTINA, 2008).

De acordo com Cavalcante et al. (2008), dos $5.783 \mathrm{Km}^{2}$ da superfície do DF, cerca de 93\% está coberto por unidades de conservação. São unidades federais e distritais, englobando várias categorias com diferentes usos - APAs, Parque Nacional, Floresta Nacional, Parques Ecológicos etc.

Em 2010, no dia 22 de julho é sancionada a Lei Complementar $n^{\circ} 827$, que institui o Sistema Distrital de Unidade de Conservação da Natureza (SDUC). A lei estabelece os critérios e normas para criação, implantação, alteração e gestão das unidades de conservação no território do DF. O Art. $7^{\circ}$ descreve que as unidades de conservação dividem-se em dois grupos: proteção integral e uso sustentável (Quadro 02).

\section{Quadro 02 - Categorias de Unidades de Conservação do Distrito Federal.}

\begin{tabular}{l|l}
\hline UNIDADES DE PROTEÇÃO INTEGRAL & UNIDADES DE USO SUSTENTÁ VEL \\
\hline Estação Ecológica & Área de Proteção Ambiental \\
\hline Reserva Biológica & Área de Relevante Interesse Ecológico \\
\hline Parque Distrital & Floresta Distrital \\
\hline Monumento Natural & Parque Ecológico \\
\hline Refúgio de Vida Silvestre & Reserva de Fauna \\
\hline & Reserva Particular do Patrimônio Natural \\
\cline { 2 - 2 } &
\end{tabular}

Fonte: Art. $8^{\circ}$ e $14^{\circ}$ da Lei Complementar n ${ }^{\circ} 827 / 2010$ - SDUC. 
Nota-se, no Quadro 02, que o SDUC incorporou, praticamente, todas as categorias propostas pelo SNUC, mas sofreu alterações nas categorias de uso sustentável, pois não foram incluídas a Reserva de Desenvolvimento Sustentável e a Reserva Extrativista. Contudo foi acrescida uma nova categoria, o Parque Ecológico.

É importante lembrar que o estudo acerca das unidades de conservação revelou que a criação dessas áreas impõe a institucionalização de restrições legais ao uso dos recursos naturais e, em grande maioria das categorias - Estação Ecológica, Reserva Biológica, Parque Nacional, Floresta Nacional, Reserva Extrativista, Reserva de Fauna - demanda desapropriação dos imóveis. Verifica-se que a criação das unidades, ao restringir o uso dos recursos naturais, atinge desfavoravelmente as atividades socioeconômicas desenvolvidas em seu interior. Dessa forma, há um choque, ou seja, conservação versus desenvolvimento socioeconômico, que estabelece os conflitos socioambientais. Nesse sentido, no tópico que se segue, o objetivo é estudar o tema conflitos socioambientais.

\subsection{CONFLITOS SOCIOAMBIENTAIS}

Um dos pontos do objetivo principal desta pesquisa é analisar os conflitos socioambientais no território da Sub-bacia do Córrego Chapadinha. Dessa forma, procura-se neste tópico fazer um resgate teórico e conceitual acerca dessa temática, ou seja, conflitos socioambientais. Na oportunidade são estudados os trabalhos de Little (2001) e Nascimento (2001) que serviram como referencial para o delineamento e análise dos conflitos identificados.

Os conflitos são objeto de estudo em diversos campos da ciência, entre elas, a Sociologia. Um dos mais importantes estudiosos foi o sociólogo alemão George Simmel. Para Simmel (apud Nascimento, 2001), os conflitos são formas de interação social, constituintes das relações sociais na modernidade e têm o importante papel de solucionar dualismos divergentes. Entende-se, portanto, que os conflitos são essenciais na existência humana, devido à sua capacidade de possibilitar o alcance a uma unidade, seja em favor de uma ou de outra parte, ou talvez em benefícios das duas partes. De acordo com o autor, os conflitos são parte integrante das sociedades e estas se constroem por meio deles.

Conforme Little (2001), os conflitos sempre existiram no seio da sociedade e estão presentes em todas as esferas da vida humana - psicológica, política, econômica, religiosa, social, cultural -, bem como em suas relações - conjugais, trabalhistas, étnicas, 
internacionais. Contudo, nos últimos anos, um tipo de conflito vem ganhando força tanto em importância quanto em número, os conflitos socioambientais.

Para Little os conflitos socioambientais são formas de disputas entre grupos sociais devido aos tipos de relação que eles mantêm com seu meio natural. Conforme o autor, o termo engloba três dimensões básicas: 1) o mundo biofísico e seus múltiplos ciclos naturais; 2) o mundo humano e suas estruturas sociais; e 3) o relacionamento dinâmico e interdependente entre esses dois mundos. Nesse sentido, agregados a essas dimensões estão três tipos de conflitos socioambientais descritos pelo autor: 1) os conflitos em torno do controle sobre os recursos naturais; 2) os conflitos em torno dos impactos gerados pela ação humana e da natureza; e 3) os conflitos em torno do uso dos conhecimentos ambientais.

Nesse contexto, podemos sublinhar dois conflitos socioambientais que são bastante recorrentes na história ambiental no mundo e no Brasil e que estão relacionados aos conflitos em torno do controle sobre os recursos naturais. $\mathrm{O}$ primeiro diz respeito à qualidade de vida, que envolve o meio ambiente e a saúde humana. O segundo refere-se aos conflitos em unidades de conservação da natureza.

Com relação ao primeiro, Little (2001) relata que a intervenção humana nos ciclos naturais nos processos para ganhar sustentação e desenvolvimento econômico gera muitos impactos, que são nefastos tanto para o funcionamento da natureza em si quanto para os seres humanos. Além do mais, muitas vezes, os grupos sociais, que fazem as intervenções e recebem benefícios diretos delas, não sofrem dos impactos negativos disso, enquanto outros grupos que não recebem nenhum benefício sofrem diretamente os impactos com o processo. Esses conflitos estão ligados ao meio ambiente e à saúde humana.

Nesse contexto, Bursztyn (2001) explana que, no século XX, a degradação das condições ambientais que afetam a qualidade de vida provocou a reação social. Assim, uma série de manifestações de grupos sociais passou a fazer parte do dia a dia das nações democráticas. O autor frisa que são inúmeros os exemplos, no entanto, o efeito do derramamento de mercúrio na Baía de Minamata, no Japão, em 1956, foi um dos marcos mais relevantes. À época, diagnosticaram ocorrências de disfunções neurológicas em seres humanos e animais que se alimentaram de peixes da baía, contaminada por mercúrio, lançado por uma indústria chamada Chisso em um rio que deságua no mar (BATISTA, 2008).

"Acidentes e conflitos sociais em torno das causas ambientais foram se tornando fatos corriqueiros da vida, no mundo industrializado e globalizado" (Bursztyn, 2001, p. 7). Os casos foram se multiplicando, por exemplo, a luta de ecologistas contra a ampliação dos 
aeroportos de Frankfurt (Alemanha) e de Narita (Japão); contra os derramamentos de óleo nos oceanos, como o naufrágio do petroleiro Torrey Canion, em 1967 e contra o vazamento do Exxon Valdez, em 1989, na costa do Alasca. No caso do Exxon Valdez, por pressão da sociedade, o custo da correção dos efeitos do acidente foi imputado a seus responsáveis.

No Brasil, a história dos conflitos dispõe de vários exemplos. Contudo a luta da população de Porto Alegre, no Rio Grande do Sul, em 1970, contra a indústria de celulose Boregaard, pode ser considerada o marco político das questões ambientais. Dali surgiu um importante movimento de defesa da qualidade do meio ambiente, reunido em torno da Associação Gaúcha de Defesa do Meio Ambiente (BURSZTYN, 2001). Outros exemplos podem ser citados, tais como a poluição em Cubatão e os efeitos dramáticos sobre a saúde das populações locais; a proliferação de garimpos na Amazônia; a instalação de grandes projetos hidrelétricos pelo país.

Como bem destaca Bursztyn (2001), no caso dos empreendimentos hidrelétricos, há um choque entre os interesses desenvolvimentistas e a populações atingidas. Esses empreendimentos são mais complexos, pois a cadeia de desenvolvimento causa conflitos com atores tanto das áreas rurais quanto das áreas urbanas.

Nesse sentido, há de se observar dois pontos fundamentais: o primeiro está nos conflitos que derivam da inundação de determinadas áreas, dependendo da escala do projeto, pode abarcar vários municípios e cidades que os compõem; o segundo ponto está nos conflitos gerados com a transmissão da energia por meio das linhas, que têm algumas características, como extensão e forma de traçado linear.

Dois casos podem ilustrar, perfeitamente, essas situações. Segundo Cabral (2001), na década de 1990, a construção da usina hidrelétrica de Itá, entre os Estados de Santa Catarina e Rio Grande do Sul, alagou mais de 10 mil hectares e atingiu parcialmente onze municípios, sete em Santa Catarina e quatro no Rio Grande do Sul. No total, 34 núcleos rurais e três áreas urbanas foram inundados. Nesse caso, além do estabelecimento da usina, o conflito se configurou em torno de outros fatores, como valor da indenização, a transformação na paisagem e os vínculos culturais.

Quanto às linhas de transmissão de energia, Mélo (2001) estudou os conflitos causados pela construção da linha Itumbiara/Brasília. Constatou-se que foram atingidos dezesseis municípios. Em sua análise, a autora inferiu várias observações, entre elas o desprezo das autorizados sobre a possibilidade do ruído produzir câncer em quem reside próximo a linhas de transmissão; as fontes de poder, que foram essencialmente política, 
econômica e tecnológica detidas por Furnas e Eletrobrás; e o baixo poder de articulação das comunidades atingidas que se resumiu em poucas ações judiciais. Dessa forma, o conflito se mostrou assimétrico: de um lado a base legal da construção, decreto de utilidade pública, editado pelo poder público federal; do outro lado, dos 403 imóveis atingidos, dezenove foram contestados judicialmente e apenas três decisões favoráveis aos proprietários (MÉLO, 2001).

Como destacado anteriormente, o segundo conflito socioambiental que envolve o controle sobre os recursos naturais ocorre em unidades de conservação. Como observado no tópico 1.1 desta dissertação, historicamente, a criação das unidades de conservação tem dado margem a um longo processo de conflitos, seja pela exclusão do acesso aos bens e serviços ambientais nelas contidos, seja pela desapropriação dos imóveis após a instituição efetiva das unidades. A análise de alguns casos permite associar o problema, principalmente, ao modelo preservacionista derivado dos Estados Unidos para o contexto mundial.

O caso do Parque Estadual de Monte Alegre no Pará é exemplar. Segundo Ibiapina (2012), a implantação do parque, ao restringir o uso dos recursos naturais, atingiu desfavoravelmente as atividades desenvolvidas pelas comunidades que residiam no parque. Este fato desencadeou conflitos entre o órgão gestor e os moradores. Conforme Ibiapina o choque entre os atores está associado à política de conservação marcada pela oposição entre seres humanos/natureza, pela noção do belo, do selvagem e do intocável e pela percepção das pessoas da comunidade, que veem o lugar onde vivem como espaço construído material e simbolicamente.

Outro caso ilustrativo é o da Reserva Biológica Marinha do Arvoredo. Vivacqua (apud Vieira e Vivacqua, 2005) pesquisou a Reserva Biológica Marinha do Arvoredo criada em 1990, localizada na porção central do litoral de Santa Catarina. O estudo indicou vários tipos de conflitos de natureza social, política e cultural. A criação gerou imediatamente desentendimentos entre pescadores artesanais, amadores e industriais, operadoras de mergulho, empreendedores do turismo e o órgão gestor da unidade de conservação. A área, antes de sua formulação como unidade, tinha a sua região usufruída por atividades pesqueiras, turismo e mergulho esportivo. A análise indicou que os conflitos socioambientais na Reserva Biológica têm assumido contornos extremamente assimétricos. Por um lado, percebe-se a influência que a indústria do turismo subaquático tem exercido nas negociações sobre o uso dos recursos ambientais e, por outro, o setor pesqueiro artesanal, que apresenta reivindicações imbuídas de pouca legitimidade perante os olhos dos tomadores de decisão. 
A pesquisa apontou que o processo de criação e implantação da Reserva Biológica Marinha do Arvoredo expressa, de maneira exemplar, os obstáculos que cercam a maturação dos sistemas de gestão de recursos naturais de uso comum num país onde ainda prevalece o modelo preservacionista. Neste modelo, as variáveis sociais e culturais têm sido sistematicamente colocadas em segundo plano.

Outros casos de conflitos que mantêm uma relação íntima e afetam, contundentemente, o meio ambiente e que não podem passar despercebidos são as ocorrências conflituosas no meio urbano, como o avanço das áreas urbanas sobre as áreas rurais e os embates do urbano versus urbano.

Sousa (2009) pesquisou o papel dos conflitos socioambientais na construção de territórios urbanos, a partir de um estudo de caso que procurou reconstituir os processos e conflitos que resultam da forma de ocupação do território do DF. Tal estudo abarcou as décadas de 1980 e 1990, esclarecendo dos conflitos ocorridos por meio de invasões e ausência do Poder Público. A área selecionada foi o território da Micro Bacia do Córrego Samambaia no DF.

Com a pesquisa, percebeu-se que a formação do território urbano - processo de transformação de área rural remanescente para área urbana - habitado por classes populares, resulta da interação da espacialização urbana das desigualdades geradas pela economia de mercado - especulação imobiliária; por omissões e ações seletivas do Estado; e pelas lutas e práticas coletivas organizadas pela população. Sousa (2009) revelou, por meio de mapeamento histórico dos anos de 1964, 1976, 1989, 1998 e 2007, que a ocupação territorial reduziu as Áreas de Proteção Permanente em 50\% de sua extensão original.

O embate urbano versus urbano pode ser retratado por casos bastante recorrentes na capital do Brasil: os famosos puxadinhos. Essas extensões territoriais urbanas, além de burlar as características urbanísticas propostas para o Plano Piloto, cujas projeções no território são de propriedade pública e acesso livre, têm provocado, também, a impermeabilização dos solos. Cidade e Peluso (2012), no artigo intitulado "Sociedade Contemporânea e Conflitos Urbanos em Brasília", citam o exemplo dos moradores da Super Quadra Sul 208 que recorreram à Justiça para manter as grades e estruturas de alvenaria que supostamente os protegem da violência externa. A Agência de Fiscalização do Distrito Federal havia determinado a derrubada dos elementos estranhos ao planejamento de Brasília e o estabelecimento de multas pela falta de cumprimento. 
Todos os exemplos citados neste tópico se enquadram na temática dos conflitos socioambientais. Para Little, essa temática representa um campo vasto de estudo. Nesse contexto, constitui uma realidade e, cada vez mais, o estudo deles representa uma necessidade urgente para definir novas pautas de ação e intervenção nas decisões que determinam como a sociedade satisfaz suas necessidades e como o governo atua para atendê-las. Assim, compreender os conflitos na construção social da realidade é importante para o conjunto da sociedade acadêmica, da comunidade política, ambiental e demais atores envolvidos, na formulação de políticas públicas que reflitam o estágio histórico das lutas sociais de vários segmentos.

Dentro dessa ideia, Little (2001) afirma que a análise dos conflitos socioambientais deve partir de uma contextualização geográfica, ambiental e histórica. Conforme o autor, geograficamente os conflitos socioambientais precisam ser compreendidos dentro de distintas escalas. Logo, o passo importante para contextualização é determinar a escala básica em que funciona. Historicamente, as mudanças políticas, sociais e culturais têm de ser levadas em conta para que se possa entender a conjuntura em que os conflitos se desenvolvem. A contextualização ambiental é de suma importância, pois o setor ambiental governamental cresceu com a criação de diversos órgãos, por exemplo, o Instituto Brasileiro do Meio Ambiente e dos Recursos Naturais Renováveis (IBAMA). Paralelamente, houve a formulação de novas leis e códigos ambientais, entre as mais importantes cita-se a lei de crimes ambientais, em 1998 e o SNUC/2000.

Para Nascimento (2001), todo conflito tem um conjunto de elementos que o caracterizam e regem sua evolução e intensidade. Entre eles estão o objeto em disputa, os atores e a natureza. Portanto esses elementos devem ser considerados para efeito de análise. A seguir é apresentado o resumo de cada elemento:

1) Objeto em Disputa: não há conflito sem um objeto em disputa, podendo ser material ou simbólico, laico ou profano, real ou irreal. Os objetos são sempre bens ou recursos escassos, ou vistos como tais.

2) Os atores: indivíduos, grupos, organizações ou Estados que têm identidade própria, reconhecimento social e capacidade de modificar seu contexto, movidos por interesses, valores e percepções que são próprias a cada um. Por isso, é fundamental compreender quais são os atores envolvidos em cada conflito.

3) A natureza: os conflitos têm natureza diferente, por isso eles podem ser de natureza econômica, política, ambiental, doméstica, internacional ou psíquica, entre outras. 
Quanto à resolução, Little a trata como um campo de ação política, pois é centrada na problemática da resolução de ditos conflitos por meio da implementação de políticas públicas e diversas estratégias e táticas políticas. Frisa-se que os conflitos socioambientais se diferenciam de outras formas de conflito por envolverem os recursos naturais, que geralmente são enquadrados com bens difusos, que afetam a coletividade. Nesse sentido, exigem-se mecanismos e instituições capazes de dirimir as divergências entre os atores que compõem os grupos sociais.

Para Little (2001), devido à complexidade e à profundidade de divergências dos conflitos socioambientais, torna-se mais fácil o tratamento do que a resolução, pois, para se resolver um conflito de forma definitiva, as múltiplas causas que deram origem a ele teriam de ser eliminadas e as divergências entre as partes solucionadas de forma pacífica, voluntária e consensualmente. Assim, é mais fácil falar em tratamento do que a resolução.

Neste sentido, Little (idem) descreve cinco tipos básicos de tratamento: 1) Confrontação, que visa aos conflitos socioambientais que estão causando danos muito fortes a um ou mais dos grupos sociais; 2) Repressão, por ser impositiva, há o risco de abusos ou ações arbitrárias por parte do Estado; 3) Manipulação Política, para os grupos sociais com pouco poder político ou econômico dentro de um conflito determinado, esse tratamento pode representar melhor opção; 4) Negociação/Mediação, que instala meios formais para seu tratamento e geralmente acontece depois da utilização de outras formas; e 5) Diálogo/Cooperação, ações que procuram eliminar as causas básicas do conflito e tentam substituir as relações de desconfiança por ações colaborativas, com participação dos atores envolvidos.

Em síntese, os conflitos socioambientais passaram a ser ponderados como uma questão importante e se configuraram como fatos sociais que promovem disputas, permitindo argumentações e negociações entre os grupos neles envolvidos. Salienta-se que os conflitos socioambientais envolvem grupos sociais distintos, com diferentes modos de apropriação e de significação do território, bem como de seu uso. Nesse sentido, no tópico que se segue, são estudados os temas território e uso do território, pois eles compõem os eixos que envolvem os embates no território da Sub-bacia do Córrego Chapadinha. 


\subsection{USO DO TERRITÓRIO: CONCEITO E MAPEAMENTO}

Outro ponto importante do objetivo principal da pesquisa é analisar as influências dos conflitos socioambientais na dinâmica do uso do território da Sub-bacia do Córrego Chapadinha. Então, neste tópico, trabalham-se os conceitos inerentes ao território e ao seu uso e, posteriormente, citam pesquisas que tratam do mapeamento da dinâmica territorial, que contribuíram para a elaboração da representação temática do território da Sub-bacia.

O território está entre as categorias fundamentais do conhecimento geográfico e é composto pelos entes da natureza - solo, vegetação, água - e a sua interação com a população. Para Santos (2008), há uma identidade e uma relação de pertencimento - pertencer àquilo que nos pertence. Assim, o território é a base do trabalho, da residência, das trocas materiais e espirituais, da vida, sobre os quais ele - o território - influi.

Para Albagli (2004), cada território é produto da intervenção e do trabalho de um ou mais atores sobre determinado espaço. Dessa forma, o território não se reduz somente ao concreto é, também, um campo de forças e relações sociais que se projetam no espaço. Para a autora, a gênese, a dinâmica e a diferenciação dos territórios são vinculados à dimensão física - naturais e artificiais; à dimensão econômica - o que, como e quem nele produz; à dimensão simbólica - relações culturais e constitutiva da identidade; e à dimensão sociopolítica interações sociais e relações de dominação e poder.

Quanto ao uso do território, Anjos (2008) o entende como o resultado dos tipos diferenciados de apropriações do espaço, se caracterizando como um fato físico e social, político e econômico, categorizável e possível de dimensionamento. Segundo o autor, o conhecimento do uso do território é de suma importância, principalmente quando se trabalha com dois ou mais momentos históricos, com espaços de tempo significativos e informações necessárias à interpretação da dinâmica territorial.

Nesse sentido, a pesquisa com espaços de tempo definidos possibilita questionamentos importantes, por exemplo, que tipo de habitação havia em tal lugar? Onde estão as áreas mais transformadas territorialmente? Que forma de uso antecedia a expansão urbana? Quais as ocupações que comprometem os mananciais? Enfim, tais questionamentos podem fornecer diversos elementos necessários referentes à dinâmica territorial (ANJOS, 2008).

Diante da necessidade de se obter informações confiáveis acerca da dinâmica do uso do território nas bacias hidrográficas brasileiras, torna-se imprescindível a utilização de ferramentas que sirvam como perspectiva de fontes de informações e manipulações de dados 
geográficos. Nesse contexto, o sensoriamento remoto (SR) e o sistema de informação geográfica (SIG) são ferramentas bastante úteis. Nas décadas de 1980 e 1990, os produtos de SR e as tecnologias computacionais para manipulação e referenciamento da informação territorial tiveram avanços, significativos, como fontes geradoras de informações de dados geográficos (ANJOS et al., 2002).

De acordo com Florenzano (2007), para se obterem informações de maneira relativamente rápida e segura, o SR é uma importante ferramenta no mapeamento e na identificação de feições terrestres, com possibilidades de uso de imagens multitemporais. Nesse sentido, os produtos de SR, como ferramenta para mapeamento do uso do território, mostram-se como uma alternativa viável e de custo relativamente baixo, às vezes, gratuito, por exemplo, os produtos dos sensores orbitais disponibilizados abordo dos satélites americano Landsat. Os sensores desses satélites são capazes de captar as imagens da terra, abrangendo extensas áreas e fornecendo informações atualizadas, que são extraídas por intermédio de interpretação visual ou processamento computacional.

Quanto ao uso do SIG, Câmara et al. (1997) destacam que é uma ferramenta com características para armazenar, analisar e manipular os dados geográficos, representativos dos objetos e fenômenos, em que a localização geográfica é necessária para tratá-los. Já Fitz (2008), define SIG como um sistema constituído por um conjunto de programas computacionais, o qual integra dados, equipamentos e pessoas com o objetivo de coletar, armazenar, recuperar, manipular, visualizar e analisar dados espacialmente referenciados a um sistema de coordenadas conhecido. As definições de SIG refletem, cada uma à sua maneira, a multiplicidade de usos e visões possíveis desta tecnologia e apontam para uma perspectiva interdisciplinar de sua utilização. Neste trabalho, SIG é entendido como uma ferramenta com as características associadas, pois a finalidade é o processamento de imagens orbitais para confecção de mapas temáticos do uso do território da Sub-bacia do Córrego Chapadinha.

Câmara et al. (1997) ressaltam que o SIG tem várias aplicações, inclusive, sobre o uso do território; a partir dele é possível visualizar de diferentes formas os limites, com mapas temáticos e descrições associadas. Por exemplo, Anjos et. al (2002) realizaram o mapeamento do uso do território no DF, relativo ao ano de 1964, na escala de 1:100.000. Os autores definiram as categorias de uso em dois blocos. No primeiro, há as formas constituintes do espaço natural: mata, cerrado, campo cerrado, mata de galeria e lago/lagoa e, no segundo, há os aspectos dos espaços artificializados: área urbana consolidada, área urbana em formação, 
espaço agrícola, represa/barragem e solo exposto. O mapeamento revelou a conformação do DF, em 1964.

No sentido de conhecer e de buscar explicações aos fenômenos relacionados ao uso do território, várias pesquisas científicas têm sido elaboradas. Essas descrevem e classificam o seu uso, por meio de mapeamento e de quantificação. Anjos (2008) ressalta que o mapa do uso do território é uma ferramenta importante para o processo de conhecimento, planejamento e gestão territorial.

Para Flores et al. (2012), o mapeamento do uso do território é um requisito indispensável para alcançar um planejamento social e ambiental nas zonas rurais, bem como para mapear a dinâmica da paisagem. Os autores analisaram o uso da terra no município de Barreiras - BA, no período entre 1988 a 2008, com imagens do satélite Landsat. A classificação foi feita manualmente por interpretação visual em tela na escala 1:10.000, considerando as propriedades básicas da imagem de satélite, tais como cor, textura, forma, estrutura e relações de contexto. No intervalo de tempo pesquisado, a agricultura teve um crescimento enquanto a vegetação natural diminuiu. A produção agrícola irrigada por pivô cresceu de nove pivôs em 1988 para 302 em 2008, constataram os autores.

Anjos (2008) mapeou o crescimento urbano do DF de maneira cronológica nos anos de 1958, 1964, 1977, 1990, 2000 e 2007. Segundo o autor, o espaço nunca é estático e se modifica permanentemente. O mapeamento partiu dos canteiros de obras, em 1958, até a concretização da mancha urbana, em 2007 e revelou que o DF é uma síntese do Brasil: riqueza e a pobreza, o planejado e o não planejado, resultando num território de contradições. Os produtos desse tipo de mapeamento, além de poder expor o crescimento acelerado e a degradação ambiental, podem apresentar, de forma clara, a segregação sócio espacial.

Observa-se que os mapas do uso do território constituem-se em mecanismos bastante adequados para apoiar o desenvolvimento sustentável do ponto de vista ambiental e são imprescindíveis para o planejamento regional ou local do território. Assim, no processo de elaboração dos mapas de uso do território, deve-se dispor de um sistema de classificação que atenda a três principais atributos: (1) identificar as categorias utilizando terminologia existente e aceita; (2) permitir que a informação seja transmitida; e (3) permitir que se façam generalizações indutivas (FILHO; MENESES E SANO, 2007).

Nesse sentido, Filho, Meneses e Sano (2007) propuseram um sistema de classificação de uso e cobertura da terra, para o Bioma Cerrado, baseado em imagens multiespectrais do satélite Landsat. A proposta visou a mostrar aos usuários de sensoriamento remoto a 
necessidade de se organizar a legenda de mapas de uma maneira mais sistematizada, a fim de aumentar o grau de eficiência na comunicação de seus resultados. Os autores escolheram a área do DF para o estudo, pois representa uma boa amostra do Bioma Cerrado. Como resultado, foram definidos quatro níveis fundamentais: o primeiro nível na escala 1:1.000.000; o segundo nível na escala 1:500.000; o terceiro nível na escala 1:250.000; e o quarto nível na escala 1:100.000. Salienta-se que todos os níveis têm um fim específico, por exemplo, o primeiro nível trata do estudo de objetos que mostram uma elevada dinâmica, como queimadas ou culturas em grandes áreas e, dessa forma, demanda a utilização de pequenas escalas. Já o quarto nível é utilizado para mapeamentos municipais, intermunicipais e de microbacias hidrográficas, tendo, em mãos, dados de sensoriamento remoto com resolução espacial moderada que permitem representação de objetos de tamanhos menores. Nesta pesquisa, para efeito de organização da legenda foi utilizado o nível quatro, pois a unidade de estudo é uma Sub-bacia hidrográfica.

Destarte o SR e o SIG possibilitam analisar os espaços ocupados, com geração de produtos cartográficos de diferentes datas por meio do aspecto temporal das imagens de satélites.

\subsection{PROCEDIMENTOS METODOLÓGICOS}

Nesta parte são apresentados os procedimentos metodológicos adotados para a análise dos conflitos socioambientais e da dinâmica do uso do território na área reservada à pesquisa.

\subsubsection{CARACTERIZAÇÃO DA PESQUISA}

O território da Sub-bacia do Córrego Chapadinha é analisado como uma arena de manifestações, local em que os mais variados atores ocupam posições e travam embates em torno de seu uso. Dessa forma, necessitou-se de meios eficientes para subsidiar o desenvolvimento e a análise da pesquisa.

Nesse sentido, a pesquisa apresenta abordagem quantitativa e qualitativa. Conforme sugere Matias-Pereira (2010), na pesquisa quantitativa os dados são traduzidos em números para classificação e análise. Richardson (2011) realça que a quantificação possibilita a precisão dos resultados e evita distorções de análise. Portanto, o trabalho é quantitativo por 
apoiar-se em dados primários - tabela e gráficos - que mensuram as classes representativas da dinâmica do uso do território.

No que tange à pesquisa qualitativa, Matias-Pereira (2010) frisa que, nesse tipo de abordagem, existe uma relação dinâmica entre o mundo real e o sujeito, um vínculo indissociável. Desse modo, a pesquisa, também, é qualitativa, pois analisa, como objetivo principal, os conflitos socioambientais e suas influências na dinâmica do uso do território na Sub-bacia do Córrego Chapadinha em Brazlândia no Distrito Federal, assim se apodera de dados primários e secundários para análise dos conflitos socioambientais.

Salienta-se que, na pesquisa qualitativa, os dados secundários foram coletados por meio de pesquisa bibliográfica - revista, artigos, teses, dissertações, jornais e livros - e pesquisa documental - leis, decretos, resoluções, mapas, ações civis públicas, contrato de concessão de uso oneroso de imóvel rural e atas de audiências públicas. Já os dados primários foram produzidos por intermédio de pesquisa de campo, cujos instrumentos de coletas foram observações não participantes e entrevistas não estruturadas.

\subsection{2 - PROCEDIMENTOS DE COLETA E DE ANÁLISE DOS DADOS}

Neste tópico são detalhados os procedimentos de coleta e de análise dos dados na pesquisa. Ressalta-se que o estudo foi dividido em cinco etapas e os procedimentos foram definidos segundo temas para caracterizar contextos específicos, procurando sempre relacioná-los ao objeto de pesquisa. Conforme a seguir:

Etapa 1 - Estudo teórico sobre as unidades de conservação, conflitos socioambientais, uso do território e dos conceitos utilizados na pesquisa expressos no capítulo 1.

Nesta etapa, os dados foram coletados por meio de pesquisa bibliográfica - artigos e livros - e pesquisa documental (SNUC/2000 e SDUC/2010). Foram aplicados, na contextualização do processo evolutivo, os modelos de criação das áreas protegidas no mundo, no Brasil. O estudo auxiliou na compreensão de três unidades de conservação (APA da Bacia do Rio Descoberto, Floresta Nacional de Brasília e Parque Ecológico Veredinha), que englobam o território em questão.

No estudo teórico envolvendo os conflitos socioambientais, trabalhou-se com dados secundários procedentes de artigos. Entre as obras pesquisadas estão as de Little (2001) e Nascimento (2001), que nortearam o delineamento e a análise dos conflitos identificados. No estudo dos temas, recorreu-se sempre aos conceitos necessários ao pleno desenvolvimento da 
pesquisa - unidades de conservação, conflitos socioambientais, território e uso do território -, assim valeu-se do SNUC/2000 e Machado (2009) para conceituar as unidades de conservação, Little (2001) para os conflitos socioambientais, das obras de Albagli (2004) e Santos (2008) para o território e Anjos (2008) para o uso do território. Por último, por intermédio de dados secundários, fez-se referência a pesquisas que tratam do mapeamento do uso do território, sempre frisando os métodos e os resultados.

Etapa 2 - Pesquisa sobre a ocupação do território do Distrito Federal sobre a qual versa o capítulo 2:

No desenvolvimento do capítulo 2, valeu-se de diversas fontes de dados como artigos, livros, tese, jornais, revista e documentos oficiais. Os documentos oficiais utilizados - Lei $n^{\circ}$ 353/1992 e Leis Complementares $\mathrm{n}^{\mathrm{o}}$ 17/1997, 803/2009 e 854/2012 - rezam sobre os PDOT/DF de 1992, 1997, 2009 e 2012, respectivamente. Nessa etapa, fez-se uso de mapas dos planos, que subsidiaram no entendimento do zoneamento do território do DF de 1978 a 2012.

Etapa 3 - Pesquisa sobre os conflitos socioambientais no território da Sub-bacia do Córrego Chapadinha (Capítulo 3):

Esta etapa, inicialmente, contou com a caracterização do território da Sub-bacia do Córrego Chapadinha. Para tanto, foi elaborado o mapa de localização do território da Subbacia e fez-se uso de dados secundários adquiridos junto a diversas fontes (artigo e sites oficiais do GDF).

Posteriormente, precederam-se a contextualização histórica, a identificação dos principais casos conflituosos e a caracterização dos atores chaves. Neste procedimento, além de fontes de dados secundários como livro, site oficial da Administração Regional de Brazlândia e documentos oficiais, o estudo contou com pesquisa de campo, para produção de dados primários.

Salienta-se que os atores não foram eleitos no início da pesquisa e, sim, paulatinamente durante todo o processo. Assim, os atores identificados foram associações, cooperativa, moradores, mediador, políticos, ICMBio, IBRAM, TERRACAP, CODHAB e MPDFT.

Observa-se que as entrevistas seguiram um roteiro. Como ponto de partida, foram entrevistados os presidentes das entidades que representam os moradores, quatro no total (Associação dos Produtores Rurais do Projeto Maranata, Associação dos Pequenos Produtores Rurais do Capãozinho, Associação dos Produtores Rurais do Assentamento Bela Vista e 
Cooperativa Habitacional dos Servidores de Segurança Pública de Brazlândia). Na sequência, entrevistaram-se os moradores, sessenta no total (Novo Assentamento, quadras 33 e 34 da Vila São José, lotes nos antigos becos, Parque Ecológico Veredinha, Assentamento Bela Vista, Assentamento Maranata e setor Capãozinho). Depois, foi entrevistado o mediador que representa o Assentamento Maranata e o setor Capãozinho. Posteriormente, o político, exDeputado Distrital (Assentamento Bela Vista). Em seguida, os representantes do IBRAM (Parque Ecológico Veredinha), dois atores foram entrevistados. Os atores ICMBio, TERRACAP, CODHAB e MPDFT foram apontados pelos acima entrevistados, porém, devido a dificuldades burocráticas não foi possível a aplicação direta das entrevistas. Os dados sobre esses atores foram colhidos por meio de pesquisa documental.

Durante a pesquisa de campo foram utilizados, para registro das entrevistas, cadernetas, canetas, lápis, gravador de áudio digital e máquina fotográfica.

Etapa 4 - Mapeamento da dinâmica do uso do território sobre o qual versa o capítulo 3:

Esta etapa foi realizada em três fases: $1^{\mathrm{a}}$ fase, obtenção das imagens; $2^{\mathrm{a}}$ fase, processamento das imagens; e $3^{\text {a }}$ fase, elaboração dos mapas temáticos, da tabela de quantificação e dos gráficos de variação das classes do uso do território. Primeiramente, foram obtidas quatro imagens do sensor Thematic Mapper do satélite americano Landsat 5, em quatro momentos: 1984, 1994, 2004 e 2011, perfazendo 27 anos de recorte temporal (Quadro 03). A obtenção das imagens ocorreu por meio de download no catálogo da Divisão de Geração de Imagens do Instituto Nacional de Pesquisa Espacial (INPE).

Quadro 03 - Características das Imagens Obtidas.

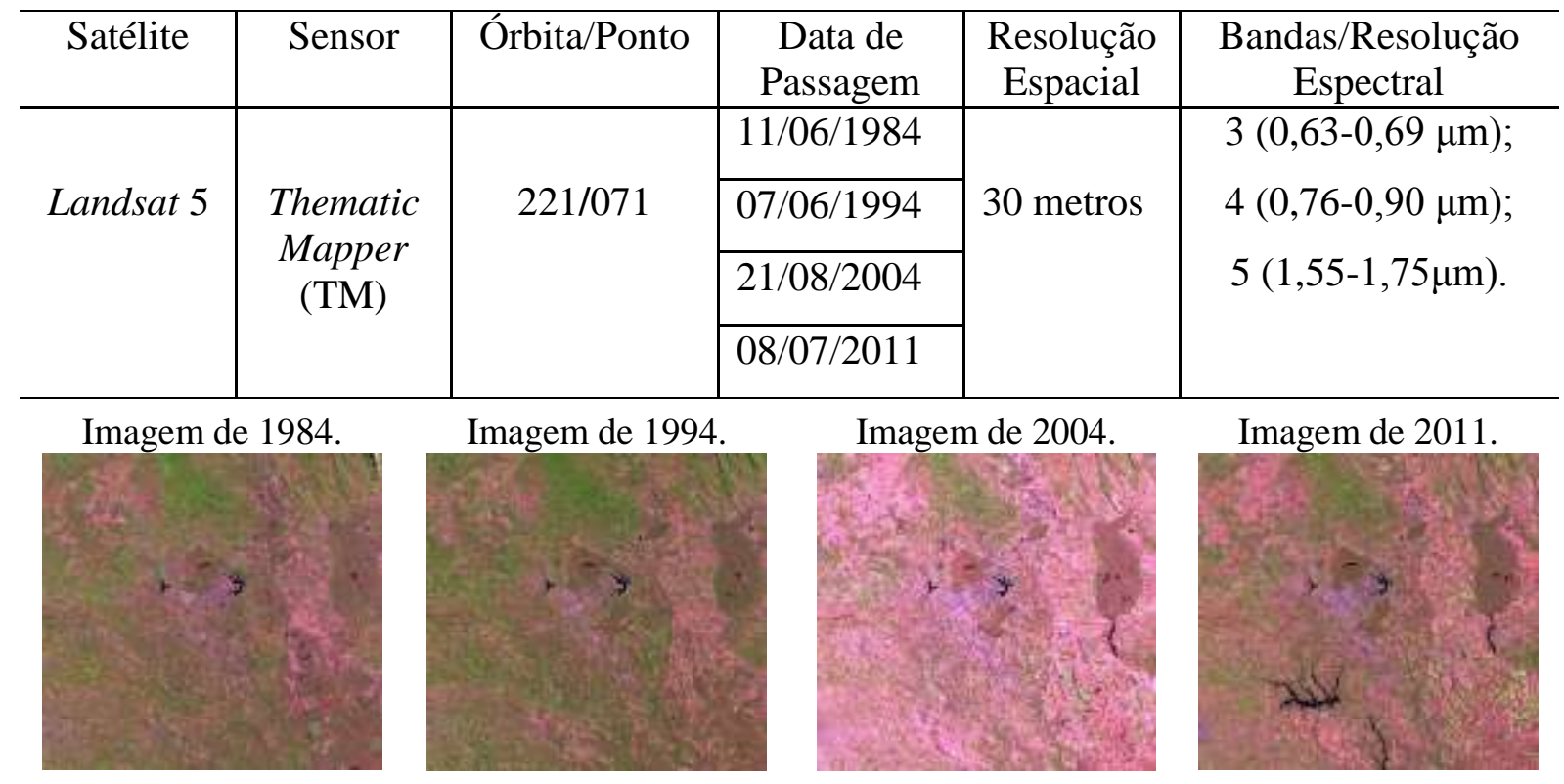


A segunda fase consiste no processamento das imagens. O processamento foi realizado com o suporte do SIG Quantum GIS, que envolveu o georreferenciamento, a delimitação do território da Sub-bacia e a classificação do uso do território. As curvas de nível e também a base acessória de vias é oriunda da base cartográfica do Distrito Federal do ano de 2010, disponibilizada pela Agência de Desenvolvimento do DF (TERRACAP). Já a base hidrográfica do DF foi disponibilizada pelo Instituto Brasília Ambiental (IBRAM). Salientase, que o georreferenciamento das imagens aconteceu com base no sistema de coordenadas UTM, sendo o território da Sub-bacia do Córrego Chapadinha localizado na zona 23 sul. O Datum utilizado foi o WGS 84; a delimitação do território da Sub-bacia adveio com base na vetorização dos divisores topográficos das curvas de nível com equidistância de 5 cinco metros. A vetorização das classes do uso do território foi efetuada manualmente por interpretação visual, considerando as propriedades básicas da imagem de satélite, tais como cor, textura, forma, estrutura e relações de contexto. A composição da legenda corresponde ao quarto nível proposto por (FILHO; MENESES E SANO, 2007) e foram identificadas oito classes, conforme relação: 1) Mata de Galeria, 2) Reflorestamento, 3) Área Urbana com Alta Densidade, 4) Pastagem, 5) Cerrado, 6) Campo limpo, 7) Cultura e 8) Lagos. Por fim, na terceira e última fase, foram elaborados quatro mapas temáticos que subsidiaram a construção da tabela de quantificação e de oito gráficos de variação das classes do uso do território. Para a construção dos gráficos, valeu-se do software Excel 2010.

A análise desta Dissertação se deu com base nas informações produzidas em cada uma das etapas da pesquisa, as quais seguiram uma sequência lógica de forma a conduzir as novas informações focadas sempre no objetivo principal da pesquisa.

Ademais, é importante salientar que a análise das influências dos conflitos socioambientais na dinâmica do uso do território ocorreu com base na comparação dos dados qualitativos contidos na imagem de localização de cada conflito, com os dados qualitativos compreendidos nos mapas temáticos e com a quantificação de cada classe, tópicos 3.2 e 3.3 desta pesquisa, respectivamente. Após a comparação, foi traçada a dinâmica completa do território pesquisado.

Etapa 5 - Conclusões e recomendações sobre as quais versam o capítulo 4.

Por fim, na figura que se segue, apresenta-se a estrutura metodológica da pesquisa no território da Sub-bacia do Córrego Chapadinha. 
Figura 01 - Estrutura Metodológica da Pesquisa no Território da Sub-Bacia do Córrego Chapadinha.

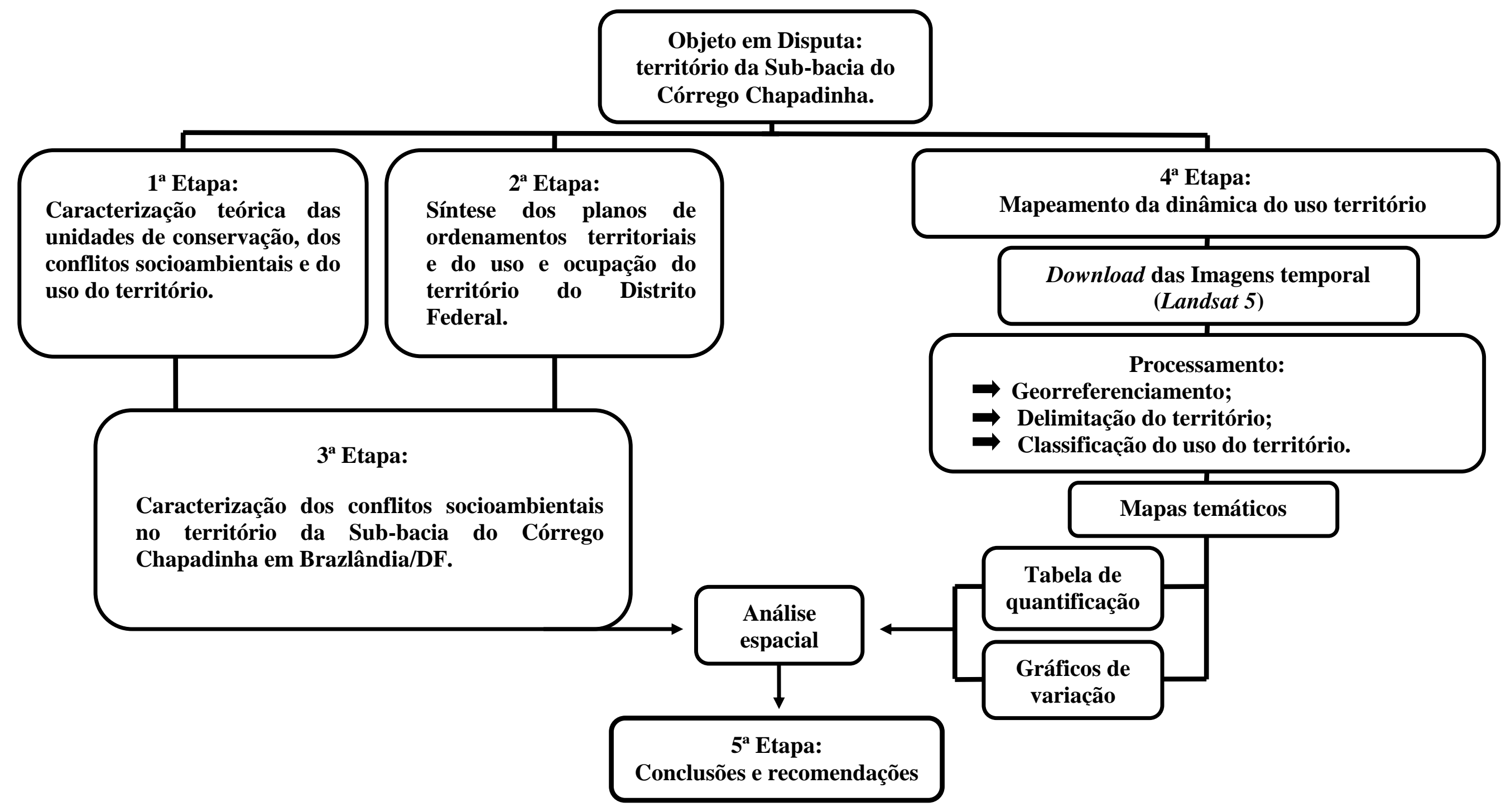


CAPÍTULO 2

USO E OCUPAÇÃO DO TERRITÓRIO NO DISTRITO FEDERAL SÍNTESE 


\section{USO E OCUPAÇÃO DO TERRITÓRIO NO DISTRITO FEDERAL - SÍNTESE}

Este é o mais curto dos capítulos do desenvolvimento, porém não menos importante que os demais; aborda, brevemente, o processo de ocupação do DF. Em seguida, descrevemse os planos de ordenamento territoriais propostos para o DF, de 1978 até 2012. Salienta-se que o objetivo do capítulo é subsidiar o entendimento dos conflitos socioambientais apresentados no capítulo 3.

\subsection{USO E OCUPAÇÃO DO TERRITÓRIO DO DISTRITO FEDERAL}

Pode-se afirmar que, mesmo antes de sua criação, o DF contou com diversos estudos técnicos destinados ao planejamento de sua ocupação. Entretanto os mais relevantes e que se apossaram de estudos de campo são a Comissão Exploradora do Planalto Central, conhecida como Missão Cruls, em 1892 e a Comissão de Estudos para Localização da Nova Capital, em 1946 (CAVALCANTE et al, 2008).

A Missão Cruls foi a primeira expedição científica organizada para identificar o local de implantação da futura capital e seu relatório ainda hoje constitui importante fonte de dados sobre a região. A Comissão de Estudos para Localização da Nova Capital contratou o levantamento aerofotogramétrico de uma área de $50 \mathrm{mil} \mathrm{km} 2$, executado pela empresa norte americana Donald J. Belcher. O levantamento contemplou cinco sítios, dos quais um foi escolhido pela comissão para implantação de Brasília.

Em 1956, o projeto foi assumido por Juscelino Kubitschek, que, logo depois de tomar posse, lançou o Concurso Nacional do Plano Piloto da Nova Capital do Brasil, vencido por Lúcio Costa. O projeto vencedor foi elaborado conforme os princípios da Carta de Atenas 2, inspirada no modelo modernista, cuja característica principal é a setorização urbana, segregando os espaços conforme seus usos: residencial, institucional, comercial e de circulação.

O Plano Piloto (Figura 02) proposto por Lúcio Costa, além de promover uma expressão urbanística própria para Brasília, tinha também o aspecto relevante de expressar a principal característica, que é ser sede do governo federal (ANJOS, 2008). 


\section{Figura 02 - Plano Piloto de Brasília}

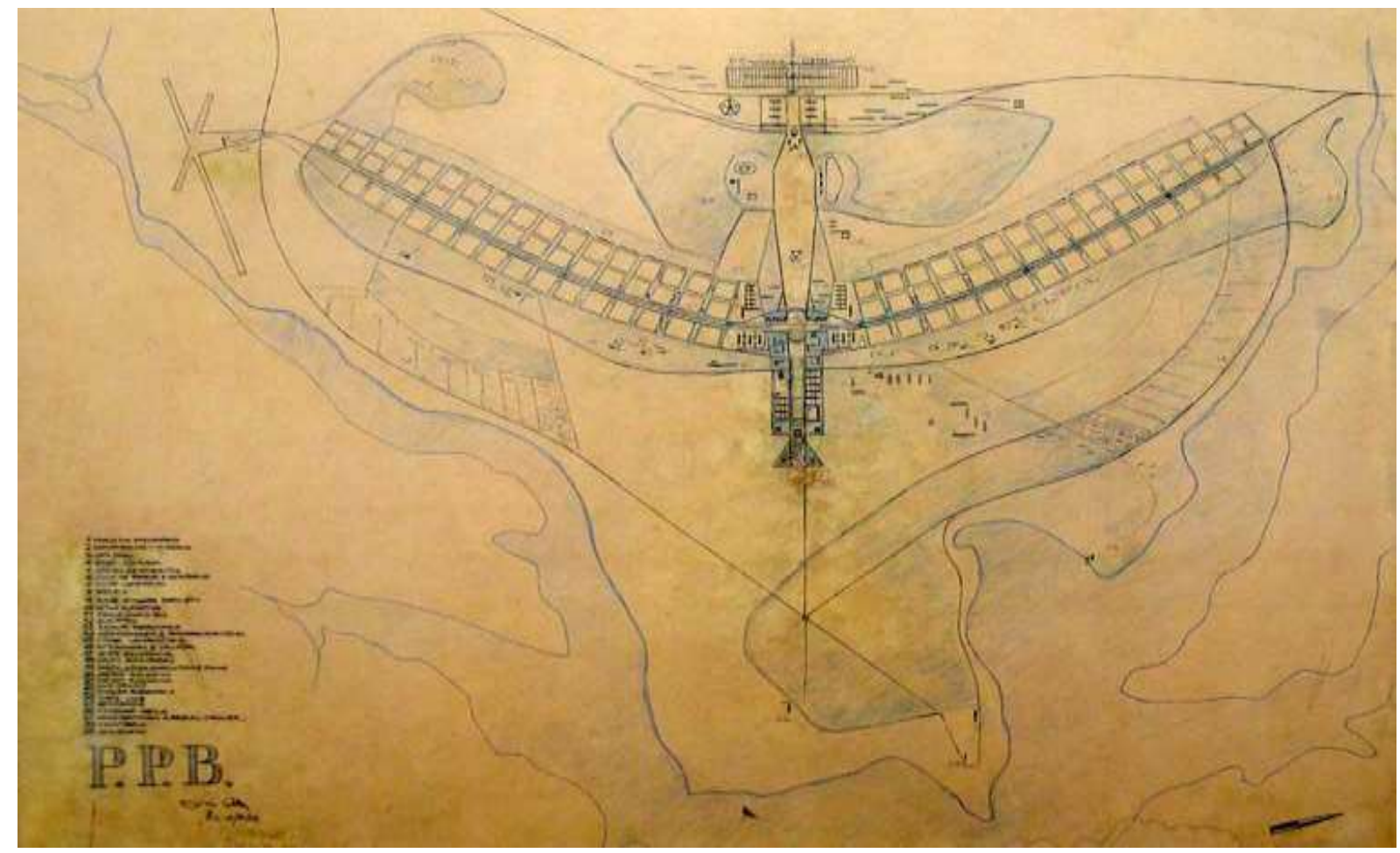

Fonte: COSTA, Graciete Guerra. As regiões Administrativas do Distrito Federal de 1960 a 2011.

Nesse sentido, buscando cumprir o objetivo estabelecido no Plano Piloto, o presidente instituiu, por meio da Lei $\mathrm{n}^{\mathrm{o}}$ 2.874/1956, a Companhia Urbanizadora da Nova Capital (NOVACAP), para a qual foi dada a responsabilidade das obras públicas e urbanização, de fornecimento de água, de energia bem como a administração das terras públicas do DF, ou seja, a finalidade de gerenciar e coordenar a construção da nova capital (NOVACAP, 2014).

Com o início da construção de Brasília, deflagrou-se um processo migratório de pessoas para trabalhar nas obras. Milhares de pessoas se deslocaram das regiões Sudeste, Sul, Centro-Oeste e principalmente da região Nordeste, aumentando substancialmente o número de habitantes do DF.

Enfatiza-se que os primeiros habitantes do DF foram os moradores das cidades de Planaltina (1859) e Brazlândia (1933). Em 1957, a população era de 12.283 pessoas que moravam em Planaltina, Brazlândia e fazendas próximas a essas comunidades (CODEPLAN, 2012).

Durante as primeiras décadas de existência da nova capital, o índice de crescimento populacional no DF era bastante expressivo. Verifica-se, na Tabela 01, que essa situação determinou, até 1970, a predominância da contribuição migratória sobre a vegetativa na composição da taxa de crescimento, motivadas pela política governamental de incentivo à 
atração de mão de obra para a capital levando a uma taxa média geométrica de crescimento anual de $14,39 \%$ para o período de 1960/1970 e 8,15\% para 1970/1980. Dessa forma, no período mais intenso da construção de Brasília, as correntes migratórias constituíam o principal fator da formação populacional do DF.

Tabela 01 - Evolução da População do Distrito Federal, Taxa Média Geométrica de Crescimento Anual e Densidade Demográfica - 1957- 2010

\begin{tabular}{l|r|r|r}
\hline Anos & População & TMGCA (1) (\%) & Densidade Demográfica Hab/Km ${ }^{2}$ \\
\hline 1957 & 12.283 & - & 2,12 \\
\hline 1959 & 64.314 & 128,82 & 11,11 \\
\hline 1960 & 140.164 & 117,94 & 24,21 \\
\hline 1970 & 537.492 & 14,39 & 92,84 \\
\hline 1980 & 1.176 .935 & 8,15 & 203,30 \\
\hline 1991 & 1.601 .094 & 2,84 & 276,57 \\
\hline 2000 & 2.051 .146 & 2,79 & 354,31 \\
\hline 2010 & 2.570 .160 & 2,28 & 444,07 \\
\hline
\end{tabular}

Fonte: Censo Experimental e Censos Demográficos - IBGE apud (Codeplan, Distrito federal em Síntese - Informações Socioeconômicas e Geográficas).

(1) TMGCA - Taxa Média Geométrica de Crescimento Anual entre períodos.

Frisa-se que o Plano Piloto contemplava apenas a nova capital - Brasília. Os milhares de trabalhadores ficaram excluídos, dando início ao favelamento do perímetro urbano de Brasília. A partir daí, houve a intenção de conter o crescimento da cidade e estabelecer uma política de criação sistemática de núcleos urbanos periféricos.

De acordo com Setti et al (2005), em 1960, foi elaborada a primeira referência legal quanto à criação das cidades satélites, que seriam núcleos autônomos periféricos a Brasília. A formação das cidades satélites, que foram previstas, mas não planejadas, não possuía os mesmos cuidados e a mesma preocupação em relação à ocupação quando comparadas a Brasília. Historicamente, o poder público sempre se preocupou em acabar com as favelas próximas a nova capital, não para resolver o problema, mas para afastá-las (DOYLE, 1996).

Desde a construção de Brasília, as invasões passaram a justificar a criação de assentamentos populacionais oficiais e, posteriormente, foram transformados em regiões administrativas, institucionalmente. O problema é que a formação de assentamentos muitas vezes se transformava em conflitos latentes.

Nesse sentido, destacam-se três conflitos ligados ao uso e a ocupação do território. O primeiro conflito que merece atenção foi a pressão exercida pelos moradores da então Cidade 
Livre, para a aceitação desse assentamento pioneiro, pois a cidade seria erradicada depois da inauguração da nova capital. $\mathrm{O}$ assentamento exercia um papel fundamental para os trabalhadores e demais moradores que vieram desde a construção da cidade, pois era o único local que oferecia meio de atendimento básico para a população, diferentemente de outras localidades mais distantes como Brazlândia e Planaltina. Como resultado bem-sucedido do Movimento Pró-fixação e Urbanização do Núcleo Bandeirante, que congregou moradores de várias origens e status social, o núcleo urbano foi fixado, definidamente, em 1961 (CAMPOS, 2010).

O segundo conflito começou na década 1970, no regime militar, e terminou na década 1980, especificamente no início do ano de 1988, com a criação da comunidade de Ceilândia. A cidade de Ceilândia foi fruto da remoção dos moradores da Vila do IAPI. Os lotes foram entregues em regime de concessão de uso e seriam legalizados posteriormente. Entretanto, no processo de legalização, as condições de compra se revelaram acima do poder aquisitivo dos moradores, o que originou o movimento denominado "Incansáveis Moradores de Ceilândia". Com o fim do regime militar, estabeleceu-se pela primeira vez uma representação legislativa eleita pela população no DF. A partir daí, os líderes do movimento se engajaram na política formal e, por meio dela, na regularização dos lotes (CIDADE E PELUSO, 2012).

O terceiro envolve a atual cidade Estrutural, que é fruto de uma invasão ocorrida na década de 1990, em que intensas manifestações se fizeram presente na história. No dia 31 de maio de 1995, a tentativa de retirada dos ocupantes por parte dos fiscais do Serviço de Vigilância do Solo acabou se transformando em uma "batalha campal". Pessoas armadas com paus e pedras resistiram à demolição de parte das casas. No dia 12 de dezembro de 2001, a Câmara Legislativa do DF aprovou o projeto de lei que autorizou a regularização da invasão da Estrutural. Atualmente, a cidade compõe a Região Administrativa do Setor Complementar de Indústria e Abastecimento - RA XXV (REVISTA CORREIO BRAZILIENSE, 2005).

Como se pode observar, o crescimento populacional vertiginoso e a demanda por moradias têm estimulado a ocupação irregular no território do DF e, por consequência, a divisão do território em regiões administrativas. De acordo com o Quadro 04, na década de 1970, havia, apenas, sete regiões administrativas oficialmente reconhecidas (Região Administrativa de Brasília - RA I, RA do Gama - RA II, RA de Taguatinga - RA III, RA de Brazlândia - RA IV, RA de Sobradinho - RA V, RA de Planaltina - RA VI e RA do Paranoá - RA VII). Entretanto, a partir da década de 1980 até os dias atuais, o número mais que triplicou. Em 2012, a região do DF perfaz trinta e uma regiões administrativas. 
Quadro 04 - Lei e Data de Criação das Regiões Administrativas do Distrito Federal

\begin{tabular}{|c|c|c|}
\hline Regiões Administrativas & Lei de Criação & Data \\
\hline RA I - Brasília & 4.545 & $10 / 12 / 1964$ \\
\hline RA II - Gama & 4.545 & $10 / 12 / 1964$ \\
\hline RA III - Taguatinga & 4.545 & $10 / 12 / 1964$ \\
\hline RA IV - Brazlândia & 4.545 & $10 / 12 / 1964$ \\
\hline RA V - Sobradinho & 4.545 & $10 / 12 / 1964$ \\
\hline RA VI - Planaltina & 4.545 & $10 / 12 / 1964$ \\
\hline RA VII - Paranoá & 4.545 & $10 / 12 / 1964$ \\
\hline RA VIII - Núcleo Bandeirante & 049 & $25 / 10 / 1989$ \\
\hline RA IX - Ceilândia & 049 & $25 / 10 / 1989$ \\
\hline RA X - Guará & 049 & $25 / 10 / 1989$ \\
\hline RA XI - Cruzeiro & 049 & $25 / 10 / 1989$ \\
\hline RA XII - Samambaia & 049 & $25 / 10 / 1989$ \\
\hline RA XIII - Santa Maria & 348 & $04 / 11 / 1992$ \\
\hline RA XIV - São Sebastião & 467 & $25 / 06 / 1993$ \\
\hline RA XV - Recanto das Emas & 510 & $28 / 07 / 1993$ \\
\hline RA XVI - Lago Sul & 643 & $10 / 01 / 1994$ \\
\hline RA XVII - Riacho Fundo & 620 & $15 / 12 / 1993$ \\
\hline RA XVIII - Lago Norte & 641 & $10 / 01 / 1994$ \\
\hline RA XIX - Candangolândia & 658 & $27 / 01 / 1994$ \\
\hline RA XX - Águas Claras & 3.153 & $06 / 05 / 2003$ \\
\hline RA XXI - Riacho Fundo II & 3.153 & $06 / 05 / 2003$ \\
\hline RA XXII - Sudoeste/Octogonal & 3.153 & $06 / 05 / 2003$ \\
\hline RA XXIII - Varjão & 3.153 & $06 / 05 / 2003$ \\
\hline RA XXIV - Park Way & 3.255 & $29 / 12 / 2003$ \\
\hline RA XXV - SCIA (Estrutural)(1) & 3.315 & $27 / 01 / 2004$ \\
\hline RA XXVI - Sobradinho II & 3.314 & $27 / 01 / 2004$ \\
\hline RA XXVII - Jardim Botânico & 3.435 & $31 / 08 / 2004$ \\
\hline RA XXVIII - Itapoã & 3.527 & $03 / 01 / 2005$ \\
\hline RA XXIX - SIA(2) & 3.618 & $14 / 07 / 2005$ \\
\hline RA XXX - Vicente Pires & 4.327 & $26 / 05 / 2009$ \\
\hline RA XXXI - Fercal & 4.745 & $29 / 01 / 2012$ \\
\hline
\end{tabular}

Fonte: Codeplan, Distrito federal em Síntese (Informações Socioeconômicas e Geográficas).

Nota: (1) SCIA - Setor Complementar de Indústria e Abastecimento - inclui a Vila Estrutural

(2) SIA - Setor de Indústria e Abastecimento. 
O crescimento urbano do DF é objeto de estudo em vários campos da ciência com diversos posicionamentos, que consideram o social, o político, o econômico e o ambiental. Contudo a pesquisa geográfica pode agregar todos esses posicionamentos de maneira a revelar a ocupação do território ao longo do tempo. Nesse sentido, Anjos (2010) mapeou o crescimento urbano do DF de 1964 a 2010, bem como identificou os vetores desse crescimento. O trabalho resultou em uma sequência de mapas temáticos, os quais mostraram a incorporação sucessiva de novas áreas no conjunto da cidade, fruto de uma criação coletiva, registrando feições momentâneas do espaço urbano, com formas e ritmos diferenciados.

De acordo com o Gráfico 01, em 1964, o DF contava com uma mancha urbana de 4.588 hectares; em 1977, revela um conjunto urbano expandido representando o primeiro boom do processo de crescimento, com um incremento na mancha de 11.526 hectares; em 1990, o DF contava com um conjunto urbano de 30.962 hectares; em 2000, a superfície era de 64.690 hectares, portanto, mais que o dobro da área urbana de 1990; em 2010, último ano do mapeamento, a mancha urbana representou um ritmo acelerado de transformação territorial e uma ampliação significativa no conjunto representando 90 mil hectares.

\section{Gráfico 01 - Evolução da Área Urbana Total do DF (hectares): 1964-2010.}

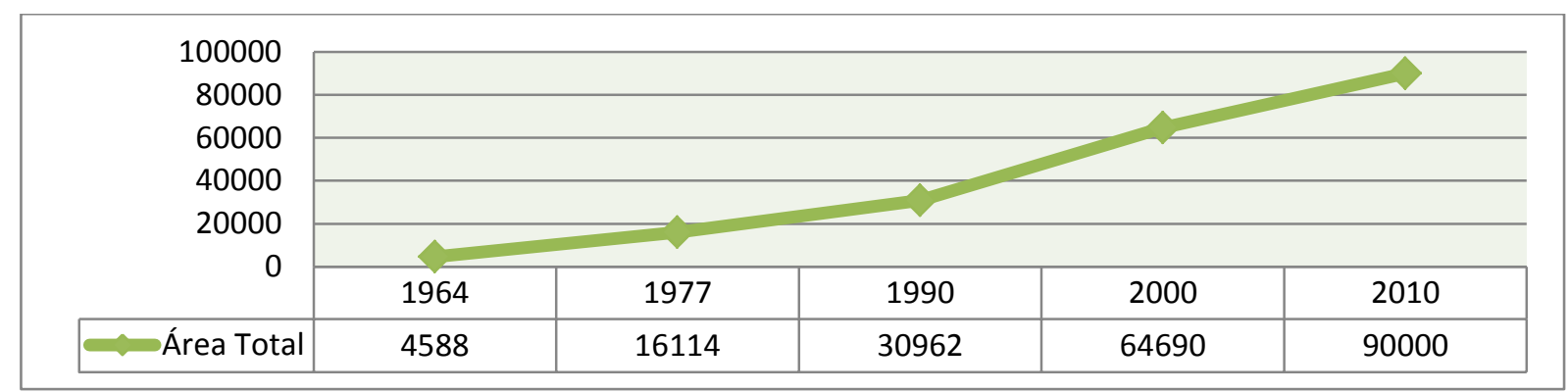

Fonte: ANJOS, Rafael Sanzio Araújo. Monitoramento do Crescimento e Vetores de Expansão de Brasília. PAVIANI, Aldo et al (orgs). Brasília 50 Anos da Capital a Metrópole. Brasília: Editora Universidade de Brasília, 2010. p. 369 - 395.

Para Anjos (2010), o crescimento do DF reflete a sua estrutura urbana polinucleada, com uma forte segregação sócio espacial. Na visão do autor, o governo não se preocupou em tratar os problemas habitacionais existentes; mas, sim, em criar novos assentamentos, principalmente na década de 1990. Por fim, o DF se apresenta como uma síntese do Brasil: o planejado e o não planejado, a riqueza e a pobreza, resultando num território de extremos e contradições territoriais.

O desenvolvimento de um mapeamento espacial permite rever a história de fatos geográficos, reconhecer o que acontece na atualidade e capturar os deslocamentos dos fluxos espaciais. Assim, com base nas linhas de força do processo de formação e crescimento das 
manchas urbanas, verificadas a partir do mapeamento realizado no espaço do DF de 1964 até 2010, foi possível descrever o movimento dos vetores de expansão em desenvolvimento ao longo do tempo e do espaço (ANJOS, 2010).

Nesse sentido, o vetor de crescimento principal é entendido com uma extensão territorial com progressivo crescimento urbano e com tendências marcantes de continuação num futuro próximo. O condutor principal desse vetor é o sistema viário, também o fator condutor estimulador do processo de transformação espacial. O autor esclarece que, além do vetor principal, há também os vetores de expansão secundários, que são entendidos como áreas com tendência a ter seu espaço urbano acrescido, quase todos associados a um eixo rodoviário. De acordo com Anjos (2010), as tendências mais significativas são as seguintes:

1) Eixo Sobradinho, Planaltina, Fercal e Lago Oeste: nesse eixo a questão estrutural é o comprometimento ambiental causado pela alta densidade habitacional, por exemplo, as nascentes na área da Fercal e a pressão sobre o Parque Nacional de Brasília provocado pelo Lago Oeste;

2) Eixo Taguatinga, Ceilândia e Brazlândia: a questão é o uso das áreas próximas ao lago Descoberto e a consolidação dos grandes loteamentos periféricos em Águas Lindas de Goiás que constituem os fatores fundamentais da desfiguração territorial operante nessa parte do $\mathrm{DF}$;

3) Eixo Taguatinga, Samambaia e Santo Antônio do Descoberto: os elementos estimuladores básicos deste vetor de expressão na porção oeste do território do DF são a consolidação urbana de Samambaia, o fluxo em direção a Goiânia e a configuração de Santo Antônio do Descoberto;

4) Eixo Gama Entorno Sul Luziânia: com fluxo de cenário regional, interligando o centro do país à Região Sul-Sudeste, este vetor expressa o dinamismo na direção sul do DF. Agrega cidades do DF e do Estado de Goiás, sendo o mais importante vetor de expansão da dinâmica territorial;

5) Eixo Leste Vale do São Bartolomeu: nesse eixo estão definidas três linhas de crescimento, que têm como consequência fundamental o comprometimento ambiental, sobretudo, dos mananciais e da cobertura vegetal.

Com base na linha de crescimento no vetor secundário e associado ao eixo rodoviário está a previsão de crescimento da área urbana da Região Administrativa de Brazlândia, especificamente, a área situada na Sub-bacia do Córrego Chapadinha, cujo território é pesquisado nesta dissertação. No território da Sub-bacia, foi previsto um aumento 
considerável da mancha urbana de 2007 a 2015, associado a dois vetores. O primeiro é a consolidação da área rural do setor Chapadinha, às margens da via DF 430 em área urbana; e o segundo é a consolidação do Assentamento Bela Vista, às margens da via BR 080 no sentido Brazlândia/Taguatinga em área urbana. Contudo, Anjos (idem) esclarece que nem todas as manchas urbanas no DF se consolidam, seja em função de ações do Estado, por uma estabilização real do déficit habitacional, seja por estarem localizadas em áreas com restrições ambientais.

Quanto às áreas com restrições ambientais, alguns indicadores constituídos por elementos fisiográficos - solo, declividade, vegetação etc - são referências importantes na caracterização dos espaços restritivos à ocupação urbana. A observação da Figura 03, que representa a cartografia temática com as extensões dos espaços restritivos à urbanização, indica o seguinte:

1) O vale do rio São Bartolomeu, pelas manchas de espaço restritivo, constitui uma extensão que requer uma atenção particular, seja na margem direita (leste) com o avanço das grandes culturas, seja na lateral esquerda (oeste) com os distintos registros de crescimento urbano.

2) O norte-noroeste do DF apresenta vulnerabilidade dos espaços de topografia movimentada, concentração de nascentes, densidade de drenagem e vários registros de grutas e cachoeiras.

3) A área sul-sudoeste é onde se encontra o eixo principal da dinâmica territorial do DF pelos registros de espaços ambientalmente restritivos.

É importante destacar que o objeto de pesquisa desta dissertação está situado a noroeste do DF, num espaço ambientalmente restritivo com concentração de nascentes. Dessa forma, configura-se em uma área estratégica para o abastecimento público, pois a Sub-bacia do Córrego Chapadinha é um dos canais d'água que abastecem o lago Descoberto, principal manancial para consumo humano no DF.

Em sua conclusão, Anjos (2010) destaca que urbanização da região do DF deve continuar se ampliando, porém, em um ritmo lento. Nesse sentido, deve-se priorizar o entendimento holístico para a criação das alternativas de ocupação territorial, que orientem as tendências atuais não desejadas a fim de não comprometer mais o desenvolvimento e a qualidade de vida da população. Dessa forma, sugere-se a retomada das reflexões sobre os novos elementos espaciais atuantes na trama urbana do território do DF, partindo de pressupostos realistas, tanto do ponto de vista do processo de produção do conjunto urbano, com suas especificidades, quanto dos seus próprios limites. 


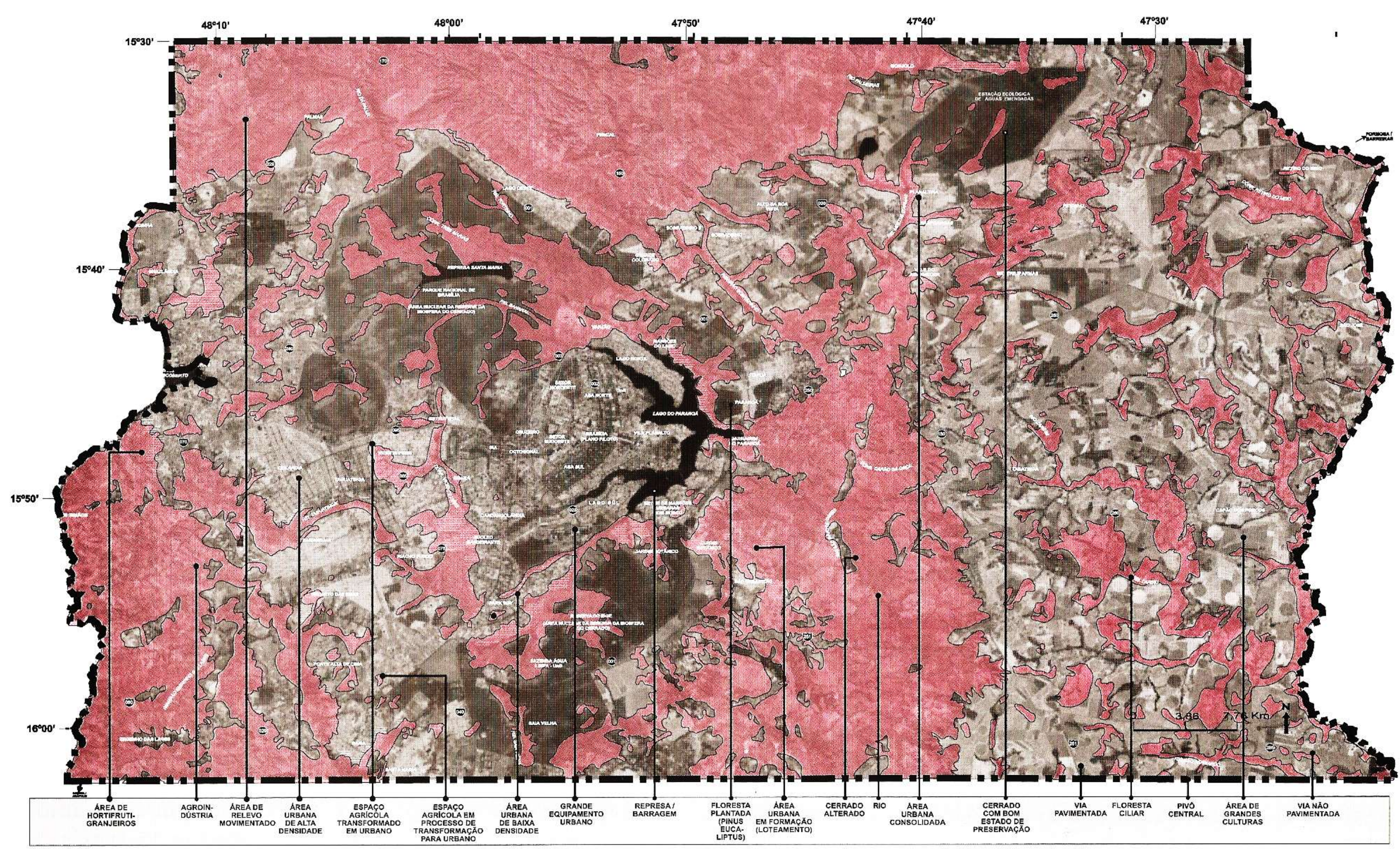

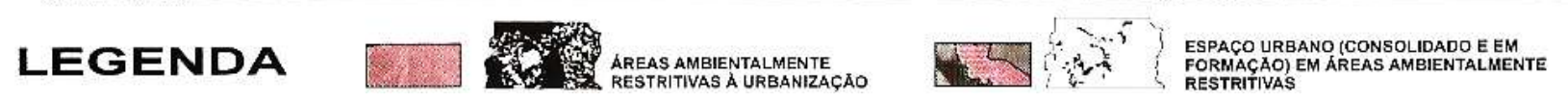


Reconhecem-se, dessa forma, que as manifestações públicas e as disputas territoriais iniciaram-se enquanto a cidade era construída. No DF, essas manifestações deflagraram-se a partir da separação entre o espaço idealizado e o planejado, além de uma gestão do território profundamente desigual. Percebe-se também que, à medida que as contradições entre o discurso do planejamento e as práticas de gestão do território se generalizavam, os conflitos se aprofundavam. De um modo geral, pode-se considerar que os conflitos ocorreram, e ainda ocorrem, pela apropriação e uso do território, local onde ocorre a reprodução social. É a luta pela moradia. Nesse sentido, no tópico que se segue, é descrito que concomitantemente as ocupações irregulares no DF, o governo local estabeleceu diversos planos de ordenamentos, numa tentativa de organizar e controlar essas ocupações.

\subsection{PLANOS DE OCUPAÇÃO E ORDENAMENTO TERRITORIAL}

Conforme já foi visto, a dinâmica da ocupação do DF surge com a implantação do Plano Piloto de Lucio Costa, início do processo de consolidação de Brasília como a nova Capital do Brasil. Foi a partir dessa consolidação que se desencadeou a implantação das cidades satélites. O plano inicial era o de implantá-las somente quando Brasília atingisse 500 mil habitantes (CAVALCANTE et al, 2008). Entretanto, já durante a construção de Brasília, a necessidade de abrigar o contingente de operários e demais imigrantes levou ao surgimento precoce das cidades satélites. Assim surgiram Taguatinga (1958), Gama (1960) e o Núcleo Bandeirante (1961).

Segundo Cavalcante et al. (idem), após a inauguração de Brasília, numa tentativa de controlar o processo de urbanização do DF, foi aprovado o primeiro documento de zoneamento, Decreto Federal no 163/1962, que dividiu seu território em área metropolitana, área das cidades satélites e área rural. Em 1966, foi aprovado o Código Sanitário do DF, e, em 1970, foi elaborado o Plano Diretor de Água, Esgoto e Controle da Poluição. Este plano propôs a restrição da ocupação na bacia do Paranoá (SEDUMA apud CAVALCANTE et al, 2008).

Nas décadas subsequentes ao decreto $n^{\circ}$ 163/1962, o DF contou com a formulação de oito planos. Sete deles tinham a pretensão de ordenar o território do DF, Plano Estrutural de Ordenamento Territorial (PEOT), Plano de Ocupação Territorial (POT), Plano de Ocupação e Uso do Solo (POUSO) e os Planos Diretores de Ordenamento Territorial de 1992, 1997, 2009 
e 2012 e um dedicado exclusivamente à área tombada de Brasília, Proposta Brasília Revisitada - 1985/1987.

O primeiro dos planos foi o Plano Estrutural de Ordenamento Territorial (PEOT), em 1977, aprovado pelo Decreto $\mathrm{n}^{\circ} 4.049 / 1978$. O plano foi o primeiro cenário em longo prazo no DF (CAVALCANTE et al, 2008). Dessa forma, procurou-se evitar que Brasília assumisse o modelo de urbanização das grandes cidades brasileiras e não comprometesse o seu objetivo primordial: ser a capital da República. O plano já previa o reforço à preservação da área da bacia do Paranoá e definia o quadrante sudoeste como eixo da expansão urbana (GONZALES, 2010).

O PEOT identificou áreas mais propícias à urbanização, tentando conciliar o uso do território com as melhores condições para os serviços de infraestrutura urbana. Além disso, estabeleceu áreas mais adequadas à expansão urbana direcionando atividades habitacionais e institucionais para áreas adjacentes à Taguatinga, onde hoje se localiza Águas Claras. Outras foram indicadas entre Taguatinga e Ceilândia (Apêndice A).

Segundo Setti et al (2005), o referido plano deliberava basicamente acerca da área de expansão do DF, tendo como princípio os estudos do espaço físico - tipo de solo, áreas comprometidas, usos efetivos, hidrologia, topografia e demais componentes -, o estudo da população no que diz respeito aos aspectos socioeconômicos e também a pesquisa relacionada aos condicionantes ambientais fundamentais - áreas de preservação de recursos hídricos.

Como fruto do plano na área do meio ambiente natural, está a criação das APAs da Bacia do Rio Descoberto e da Bacia do Rio São Bartolomeu, em 1983. Na área urbana, surgiu a cidade de Samambaia. Um estudo preliminar do Conselho de Arquitetura, Urbanismo e Meio Ambiente, homologado pelo Decreto $\mathrm{n}^{\mathrm{o}}$ 6.349/1981, aprovou o projeto denominado “Samambaia Estudo Preliminar 1981”, decretado pelo então governador Aimé Alcibíades Silveira Lamaison. Era o começo do primeiro assentamento previsto pelo PEOT (REVISTA CORREIO BRAZILIENSE, 2005).

Em 1985, foi elaborado o segundo plano de ocupação para o DF, o Plano de Ocupação Territorial (POT), que consolidou as propostas de expansão urbana contidas no PEOT e serviu de subsídio para todos os demais planos, subsequentes, de ordenamento. O objetivo do plano era dotar o GDF de um instrumento normativo de ocupação do território, definindo as grandes áreas ambientais, naturais, rurais e urbanas, com usos predominantes e exclusivos. Contudo o quadrante sudoeste como eixo de expansão urbana do DF e a preservação da bacia do Paranoá preconizados no PEOT se mantiveram. (CAVALCANTE et al, 2008). 
Anjos (2008) esclarece que o plano buscou efetuar um zoneamento completo do território, além de garantir as áreas necessárias aos diversos setores da economia e assegurar a preservação dos mananciais d'água. Dessa forma, o DF foi divido em seis zonas: 1) Zonas de Destinação Mista; 2) Zonas de Expansão Urbana; 3) Zonas de Interesse Ambiental; 4) Zonas de Ocupação Restrita; 5) Zonas Rurais; e 6) Zonas Urbanas (Apêndice B).

Em 1987, o Conselho de Arquitetura e Urbanismo aprovou o novo projeto de Lúcio Costa, Proposta Brasília Revisitada - 1985/1987, que passou a ter efeitos jurídicos concretos por meio do Decreto n. ${ }^{\circ}$ 10.829/1987. De acordo com a planta do Brasília Revisitada (Apêndice C), contrariamente às diretrizes vigentes até então, as novas propostas visavam o adensamento da bacia do Paranoá, com a criação de seis novas áreas habitacionais na região. Entre as novas áreas propostas, figuram os atuais setores: Sudoeste e Noroeste (GONZALES, 2010).

Para Setti et al (2005), o cerne da proposta é essencialmente a preservação do Plano Piloto, a manutenção das quatro escalas previstas originalmente (monumental, residencial, gregária e bucólica); revela, também, o adensamento e expansão ao longo das vias de ligação de Brasília às cidades satélites dentro da bacia do Paranoá.

O terceiro plano direcionado ao território do DF foi o Plano de Ocupação e Uso do Solo (POUSO), elaborado em 1990, pela Secretaria de Estado de Desenvolvimento Urbano e Habitação. O plano tinha sido aprovado pelo Conselho de Arquitetura e Urbanismo e Meio Ambiente, em 1986, no entanto só foi homologado em 1990, pelo Decreto $\mathrm{n}^{\circ}$ 12.987/1990, adquirindo, então, personalidade jurídica (COSTA, 2011).

O POUSO foi estabelecido como instrumento normativo do macrozoneamento, visando ao controle do uso e da ocupação do solo. Assim, o plano tenta dar respostas às ocupações irregulares, confirma o não adensamento de Brasília e preocupa-se com a bacia do Paranoá.

De acordo com Anjos (2008), o POUSO foi o precursor das exigências ambientais no DF. A partir desse documento, exigiu-se a solicitação do Relatório de Impacto Ambiental, antes de qualquer intervenção urbanística ou parcelamento rural no solo do DF, submetendo as intervenções aos órgãos ambientais. Conforme o macrozoneamento do POUSO (Apêndice D), o território foi categorizado em seis zonas: 1) Zonas de Destinação Mista; 2) Zonas de Expansão Urbana; 3) Zonas de Interesse Ambiental; 4) Zonas de Ocupação Restrita; 5) Zonas Rurais; e 6) Zonas Urbanas. 
Com relação aos recursos hídricos, o POUSO confirma o Decreto Federal $\mathrm{n}^{\mathrm{o}}$ 88.940/1983, que cria as APAs da Bacia do Rio Descoberto e da Bacia do Rio São Bartolomeu, implantando nelas zonas de categoria urbana e rural (SETTI et al, 2005).

Em 1988, foi promulgada a nova Constituição Federal e tornou-se obrigatório o Plano Diretor de Ordenamento Territorial (PDOT). O Art. 182 preceitua que o plano diretor é instrumento obrigatório da política de desenvolvimento e de expansão urbana de cidades com mais de 20 mil habitantes. Salienta-se que as disposições constitucionais foram regulamentadas pela Lei ${ }^{\circ} 10.257 / 2001$, que institui o Estatuto da Cidade (CAVALCANTE et al, 2008).

Nesse sentido, o plano diretor delimita as áreas urbana e rural e as zonas onde se pretende incentivar, coibir ou qualificar o uso e a ocupação, com base nas condições de infraestrutura e do meio físico, nas necessidades de proteção ambiental e nas características da ocupação existente. Na visão de Gonzales (2010), o plano diretor territorial é um instrumento do processo de evolução - expansão periférica e às transformações internas -, cuja função é dirigir, orientar e dispor normas e procedimentos para a obtenção de resultados de qualificação e de manutenção dos ambientes sócio espaciais.

Nesse contexto, com a instituição da autonomia política do $\mathrm{DF}$, com a posse do primeiro governador eleito e com a criação da Câmara Legislativa em 1991, formularam-se condições para a realização do PDOT do DF. Conforme informa Cavalcante et al. (2008), na década de 1990, foi elaborado o primeiro plano nos termos da nova Constituição Federal/1988, o PDOT/DF, aprovado pela Lei Distrital nº 353/1992.

O PDOT/1992 reforçou duas áreas de concentração urbana: a primeira concentra Brasília, Guará, Taguatinga, Ceilândia, Samambaia e Águas Claras; e a segunda, em direção a Samambaia, Recanto das Emas, Gama e Santa Maria. Desse modo, compatibilizam-se as áreas definidas para expansão urbana pelos planos anteriores. Nota-se o vetor de crescimento acentuado pela introdução da linha do metrô na direção de Brasília, Guará, Taguatinga, Ceilândia e Samambaia.

O Art. $4^{\circ}$ instituiu o macrozoneamento do DF, cujo território foi divido nas seguintes zonas: 1) Zonas Urbanas - áreas já parceladas regularmente ou que ainda serão nos termos da legislação pertinente, desde que contidas em perímetro urbano; 2) Zonas de Expansão Urbana - destinadas às futuras ocupações para fins urbanos; 3) Zonas Rurais - destinadas às atividades agrícolas, à pecuária, à extração vegetal e mineral ou outros usos complementares compatíveis com estas atividades; 3) Zonas de Interesse Ambiental - destinadas a tratamento 
específico visando à sua preservação, conservação, ou recuperação devido às características físico-ambientais, à fauna e à flora ou aos demais atributos especiais.

Com base no macrozoneamento do PDOT/1992 (Apêndice E), nota-se que há uma preocupação com a Região Administrativa de Brazlândia, local onde se concentra o objeto de pesquisa desta Dissertação. Observa-se que o PDOT apontou uma possível expansão urbana, cujo vetor de crescimento situa-se ao norte e a leste da cidade, às margens das via BR 080 e DF 430, respectivamente. Essas áreas situam-se no território da Sub-bacia do Córrego Chapadinha e deram origem ao Novo Assentamento e às quadras 33 e 34 da Vila São José, obviamente, derivadas de ocupações irregulares.

De acordo com Setti et al (2005), o PDOT/1992, apesar de apresentar objetivos voltados para a promoção do desenvolvimento sustentável, se revelou mais um plano de caráter de ordenamento territorial, restrito ao planejamento do espaço físico.

Tendo em vista a nova realidade político administrativa do DF, em 1995, o Instituto de Planejamento Territorial e Urbano do DF, vinculado à Secretaria de Obras, optou pela elaboração de um novo PDOT. A versão final ocorreu em 1997, após a aprovação pela Câmara Legislativa por meio da edição da Lei Complementar $n^{\circ} 17$. Com o novo plano, confirmaram-se a ocupação prioritária no eixo sudoeste com a intenção de incrementar os investimentos em infraestrutura urbana já existente e o reconhecimento de ser essa área a de menor grau de restrições ambientais (COSTA, 2011).

Segundo Cavalcante et al. (2008), para a definição do macrozoneamento, foram avaliados os aspectos ambientais, a dinâmica demográfica do DF, a disponibilidade de infraestrutura e de equipamentos de uso público, a capacidade dos principais eixos de transportes, a situação fundiária e os problemas de habitação.

Nesse sentido, diferentemente dos planos anteriores, no PDOT/1997, apresentou-se uma maior preocupação com o meio ambiente, principalmente, com os mananciais. Observam-se, no macrozoneamento contido no Apêndice F, que, além da Zona de Conservação Ambiental, foram estabelecidas áreas com características específicas, como as Áreas de Proteção de Mananciais.

O documento as define como sendo aquelas destinadas à conservação, à recuperação $\mathrm{e}$ ao manejo das bacias hidrográficas a montante dos pontos de captação da Companhia de Saneamento Ambiental (CAESB), sem prejuízo das atividades e ações inerentes à competência de captar e de distribuir água de boa qualidade e em quantidade suficiente para o atendimento da população. 
A preservação dos recursos hídricos foi ratificada em outra categoria preconizada no PDOT/1997: as zonas rurais. Essas foram divididas em cinco zonas de uso controlado, entre elas a Zona Rural de Uso Controlado III, que compreende a região do Projeto Integrado de Colonização Alexandre Gusmão, localizado na APA da Bacia do Rio Descoberto; a região do Núcleo Rural do Pipiripau e outras regiões localizadas na Bacia do Lago Paranoá. Essa zona foi caracterizada de maneira a salientar a importância da preservação e da gestão de importantes recursos hídricos do DF: o Lago do Descoberto, o Rio Pipiripau e o Lago Paranoá. Essa preocupação se dá pelo fato de o Descoberto ser o mais importante manancial de abastecimento do DF, de o manancial do Pipiripau ser responsável pelo abastecimento urbano da região de Planaltina e também ser responsável pela irrigação das terras de seu vale com produção agrícola significativa; e de o Lago Paranoá exigir cuidados em termos de saneamento e investimentos em termos de tratamento de esgotos.

O PDOT/1997, em linhas gerais, procurou reforçar as tendências de ocupação do território já consolidadas, enquanto restringia a ocupação de outras, principalmente as consideradas ambientalmente sensíveis, estabelecendo diretrizes especiais de ocupação tendo em vista a sua conservação.

Contudo Veríssimo (2003) critica os planos de ordenamento até então elaborados e as suas relações com o meio ambiente natural, principalmente as unidades de conservação. Para a autora, a divisão do espaço, a partir dos documentos legais, considera apenas as necessidades habitacionais, não analisa e nem avalia às relações existentes entre as demandas urbanas, rurais, sociais, econômicas, políticas e ambientais. Dessa forma, o isolamento das unidades de conservação, não são ações satisfatórias para a preservação ecológica dos ecossistemas terrestres e aquáticos.

Oliveira et. al. (2008) apontam outro aspecto importante: a sobreposição das diretrizes do PDOT, a cargo do GDF, às unidades de conservação federais, que são administradas pelo ICMBio. Conforme os autores, cerca de 93\% do território distrital está coberto por unidades de conservação, especialmente as APAs do São Bartolomeu, do Descoberto e do Planalto Central, todas federais.

Como exemplo emblemático dessa situação, os autores citam a APA do Planalto Central e a falta de articulação entre as diferentes instâncias de governo responsáveis pelo planejamento territorial. Criada em 2002, a APA abrange grande parte do território do DF e as nascentes do rio Maranhão, no Estado de Goiás. Apesar de sua grande extensão, ela ainda não 
conta com plano de manejo, para ser definido o seu próprio zoneamento e estabelecidas as condicionantes ambientais orientadoras do zoneamento do PDOT.

Salienta-se que os planos de manejo das unidades de conservação federais devem ser aprovados por meio de ato normativo do ICMBio. O PDOT, por sua vez, deve ser elaborado pelo Poder Executivo e deve ser submetido a audiências públicas e aprovado por lei complementar do DF. A ausência de diretrizes comuns de planejamento territorial entre os órgãos distritais e o ICMBio, anteriormente à revisão do PDOT, acarreta conflitos futuros entre as instituições e prejuízos à conservação da cobertura vegetal, do solo e dos recursos hídricos em áreas ambientalmente sensíveis do DF (OLIVEIRA et al, 2008).

Em 2012, após cento e sessenta e cinco Audiências Públicas e a flexibilidade no atendimento de demanda dos diversos setores da comunidade, o PDOT sofreu nova revisão por meio da Lei Complementar $n^{\circ} 803 / 2009$ (COSTA, 2011). De acordo com o zoneamento do DF (Apêndice G), o território foi divido em nove zonas. Entre as novidades em relação ao PDOT de 1997, está a inclusão da Zona Urbana do Conjunto Tombado, da Zona Urbana de Expansão e Qualificação e da Zona de Contenção Urbana.

A Zona Urbana do Conjunto Tombado corresponde à área do conjunto urbano construído em decorrência do Plano Piloto de Brasília e às demais áreas incorporadas em função de complementações ao núcleo original, ou seja, visa à proteção do conjunto urbanístico tombado como Patrimônio Histórico Nacional e reconhecido como Patrimônio Cultural da Humanidade pela UNESCO.

A Zona Urbana de Expansão e Qualificação é composta por áreas propensas à ocupação urbana, predominantemente habitacional e possui relação direta com áreas já implantadas, é também integrada por assentamentos informais que necessitam de intervenções visando à sua qualificação. Essa zona reconhece a consolidação de várias ocupações irregulares, entre elas a Sol Nascente e Pôr do Sol na Ceilândia.

De acordo com o Art. 76, a Zona de Contenção Urbana é composta por áreas urbanas localizadas nas fronteiras com as áreas rurais, caracterizada por ocupação habitacional de densidade demográfica muito baixa, de modo a criar uma zona de amortecimento entre o uso urbano mais intenso e a Zona Rural de Uso Controlado. Ela tem por objetivo assegurar a preservação e a manutenção das suas características naturais por meio do estabelecimento de parâmetros de uso e ocupação dos solos restritivos. O $\S 1^{\circ}$ do Art. 77 proíbe o parcelamento em glebas menores que dez hectares. A ocupação dessa zona causou vários debates e quem 
acompanha a história de ocupação do DF reconhece que esses aglomerados com baixa densidade podem ser perfeitamente embriões de futuras áreas urbanas.

Em 2012, a Lei Complementar $n^{\circ} 854$ atualizou novamente PDOT. A atualização do plano foi feita com base em três linhas: a revisão dos itens considerados inconstitucionais no PDOT/2009; a adequação do plano à legislação federal no que se refere à regularização fundiária e alterações que atendem ao interesse público, especialmente no que diz respeito à criação de áreas para habitação. Dessa forma, o plano se mostrou uma verdadeira lei de uso e de ocupação do solo, um plano imobiliário (FLÓSCULO, 2012). O zoneamento proposto no PDOT/2012 revela que foram acatadas as mesmas zonas do plano de 2009, com retiradas apenas dos itens considerados inconstitucionais (Apêndice $\mathbf{H}$ ).

Nesse contexto, à revelia dos planos de ordenamentos territoriais adotados ao longo de mais de cinco décadas, no DF, proliferou-se a ocupação irregular de vastas áreas na forma de loteamentos de uso urbano em áreas públicas e privadas. O crescimento populacional vertiginoso, a demanda por moradias e o preço elevado estimularam a ocupação irregular seja pelas invasões realizadas por comunidades carentes, seja pelos condomínios de classe média.

Em meados da década de 1980, já eram elevados, no DF, os preços de imóveis urbanos e era grande a demanda por moradias para as classes média e de baixa renda. A partir de 1989, foram iniciados os programas de formação de assentamentos urbanos e ampla distribuição de lotes para população de baixa renda. Isso deu origem a diversas cidades como Recanto das Emas, Riacho Fundo, Santa Maria entre outras (SEDUMA apud OLIVEIRA et al, 2008).

Direcionados à classe média, no início da década de 1990, iniciou-se a implantação dos setores habitacionais Sudoeste e Águas Claras, cujos imóveis seriam adquiridos por financiamentos bancários com juros altos. Nessa época, entretanto, já estavam em expansão os condomínios irregulares, os quais avançavam sobre áreas rurais, em terras particulares ou públicas griladas. Os condomínios fixaram principalmente na APA do Rio São Bartolomeu, direcionando a expansão urbana para uma região não prevista nos primeiros planos de ordenamento territorial (SEDUMA apud OLIVEIRA et al, 2008).

Nesse contexto, os planos diretores elaborados no DF com a realidade da ocupação do espaço evidenciam o descompasso entre o planejamento e o crescimento urbano desordenado. De fato, os esforços dos planejadores e gestores não conseguiram evitar o caos urbano que persiste até os dias atuais. 
Duas reportagens do Correio Brasiliense dão destaque a esse caos de forma dramática. A primeira matéria ocorreu nos mês de outubro de 2008. Nela apontou-se que a superfície urbana, no DF, de 1986 até 2008, cresceu 132\%. Até 1986, a taxa de ocupação urbana era de 1087 hectares ao ano, em 2008 já era de 1698 hectares ao ano. De acordo com a referida reportagem, de janeiro a agosto de 2008, foram realizadas 1465 operações para retirada de ocupações ilegais (CORREIO BRASILIENSE apud OLIVEIRA et al, 2008).

A segunda reportagem é mais recente, o jornal publicou, no mês de fevereiro de 2014, uma série de reportagens relacionadas às ocupações irregulares no DF. Conforme retrata a matéria, o Comitê de Combate ao Uso Irregular do Solo fez, em 2013, pelo menos, 958 remoções em várias localidades no DF, o Quadro 05 associa a localidade com a quantidade de remoções.

Quadro 05 - Operações do Comitê de Combate ao Uso Irregular do Solo do DF em Áreas Públicas Rurais, em 2013.

\begin{tabular}{l|r}
\hline \multicolumn{1}{c|}{ Localidade } & Remoções \\
\hline Sol Nascente & 590 \\
\hline 26 de Setembro & 158 \\
\hline Morro da Cruz & 72 \\
\hline Caub & 1 \\
\hline Caub II & 7 \\
\hline Monjolo & 4 \\
\hline N. R. Vargem da Benção & 2 \\
\hline Mestre D’Armas & 100 \\
\hline Água Quente & 13 \\
\hline N. R. Alexandre Gusmão & 7 \\
\hline N. R. Taguatinga & 4 \\
\hline
\end{tabular}

Fonte: Correio Braziliense de 18 de fevereiro de 2014, página 23.

Observa-se que os registros, ao longo do tempo, indicam que essas operações são inócuas. O Quadro 06 expõe essa situação: em 1997, o PDOT identificou 146, dois anos depois, em 1999, já eram 316. Segundo estimativa do Ministério Público do DF, em 2013, estava em torno de seiscentas invasões. 
Quadro 06 - Crescimento das Ocupações Irregulares no DF.

\begin{tabular}{l|rr}
\hline \multicolumn{1}{c|}{ Ano } & Invasões \\
\hline 1997 & 146 \\
\hline 1999 & 316 \\
\hline 2013 & $600^{*}$ \\
\hline
\end{tabular}

Fonte: PDOT (1997) e estimativa do Ministério Público* (apud Correio Braziliense de 18 de fevereiro de 2014, pg 23).

Os quadros revelam que as ocupações irregulares ocorrem frequentemente no DF e têm superado a capacidade do poder público de combatê-las. As ações dos órgãos competentes não acompanham a velocidade com que surgem e crescem as invasões. Segundo a reportagem, o próprio governo admite que algumas áreas de ocupações irregulares já estão consolidadas e a única saída é a regularização.

Pode-se constatar que o problema pode ser ainda mais grave, pois o governo não consegue mensurar com exatidão a quantidade de áreas invadidas e descaracterizadas, mesmo em se tratando de terrenos públicos. Dessa forma, o GDF não consegue inibir a proliferação dos parcelamentos e nem estabelecer um modelo que viabilize o controle e a fiscalização.

Destarte os planejadores não conseguem evitar o caos urbano. Entre as causas principais que levaram à desordenada ocupação do território do $\mathrm{DF}$, principalmente a partir da década de 1990, estão a política pública agressiva de distribuição de lotes para as camadas mais pobres da população, a grilagem de terras para implantação irregular de condomínios para classe média e a especulação imobiliária. Enfatiza-se que a especulação imobiliária, por meio de seus agentes, utiliza-se instrumentos diversos, transforma os territórios segundo os interesses econômicos e revela-se como agentes políticos, influenciando, no crescimento das cidades. Assim, os envolvidos tornam-se agentes da produção do espaço. Observa-se, então, que esses três fatores acarretaram e continuam a acarretar a ocupação do território do Distrito Federal.

A Sub-bacia do Córrego Chapadinha teve seu território moldado parcialmente nas ocupações irregulares estabelecidas no DF e será tratada no capítulo que se segue. 


\section{CAPÍTULO 3}

SUB-BACIA DO CÓRREGO CHAPADINHA: OS CONFLITOS SOCIOAMBIENTAIS E A DINÂMICA DO USO DO TERRITÓRIO. 


\section{SUB-BACIA DO CÓRREGO CHAPADINHA: OS CONFLITOS SOCIOAMBIENTAIS E A DINÂMICA DO USO DO TERRITÓRIO}

Neste capítulo, é apresentada, inicialmente, a caracterização do território da Sub-bacia do Córrego Chapadinha. Na continuidade, há a contextualização histórica com ênfase ao processo de ocupação do território, com a identificação dos principais conflitos socioambientais. Na sequência analisa-se a dinâmica do uso do território. Ademais caracterizam-se os atores e a estruturação dos conflitos.

\subsection{CARACTERIZAÇÃO DO TERRITÓRIO}

O território da Sub-bacia do Córrego Chapadinha localiza-se na Região Administrativa de Brazlândia - RA IV, a noroeste no DF e compõe a bacia do alto curso do rio Descoberto. A área abrange 2338,82 hectares, com altitude que varia de 1.030 a 1.280 metros. O território da bacia é composto por área urbana e rural, como pode ser observado na Figura 04. A área urbana é dividida em setor Tradicional, setor Norte, setor Sul, Vila São José, setor Veredas e Novo Assentamento, representando, aproximadamente, $95 \%$ da cidade de Brazlândia. A cidade está a $45 \mathrm{Km}$ de distância de Brasília (CODEPLAN, 2012). Já a área rural é composta pelo Assentamento Bela Vista, Assentamento Maranata, setor Capãozinho e setor Chapadinha.

Com relação a população, cabe explicar que não há pesquisa que determina a quantidade de habitantes por setores na RA de Brazlândia. O quantitativo geral da RA, em 2010, era de 57.542, sendo 42.353 de população urbana e 15.189 rural (CODEPLAN, 2012). Dessa forma, não há como especificar o número da população atual do objeto de estudo.

A economia conta com o setor terciário na área urbana. $\mathrm{Na}$ área rural, a economia é voltada para a produção de hortifrúti em pequenas propriedades de 2 a 5 hectares. Os principais produtos são alface, cenoura, vargem, jiló, couve, pimentão, beterraba, abóbora, tomate, goiaba, banana, morango entre outros (Empresa de Assistência Técnica e Extensão Rural do DF, 2014). Essa produção é escoada para várias regiões do DF e do Brasil.

O território é protegido legalmente por três unidades de conservação da natureza de uso sustentável: APA da Bacia do Rio Descoberto, Floresta Nacional de Brasília e Parque Ecológico Veredinha. De acordo com Empresa Brasileira de Pesquisa Agropecuária (EMBRAPA, 2013), a vegetação é composta por fitofisionomias do Cerrado como Mata de 
Galeria e Campo Limpo. O solo é representado por Latossolo Vermelho, Latossolo Vermelho-Amarelo e Cambissolo (EMBRAPA, 2013). Dessa forma, tratar da questão ambiental é muito pertinente.

A peculiaridade ambiental fica por conta dos recursos hídricos, pois o córrego Chapadinha deságua no lago Descoberto, manancial destinado ao fornecimento de água para consumo humano em diversas regiões do DF (CAESB, 2013). O Chapadinha tem como afluentes os córregos Pulador, Capãozinho e Veredinha (ICMBio, 2014). Salienta-se que, em 1978, o córrego Veredinha foi represado e deu origem ao lago Veredinha. O lago tem uma área aproximada de 86.400 metros quadrado, destinada, exclusivamente, ao lazer e ao turismo. Dessa forma, o território da Sub-bacia exerce importante papel no desenvolvimento social, econômico e ambiental na região do DF. A Figura 04 evidencia a localização da Subbacia.

Figura 04 - Mapa de Localização do Território da Sub-Bacia do Córrego Chapadinha/Brazlândia/DF.

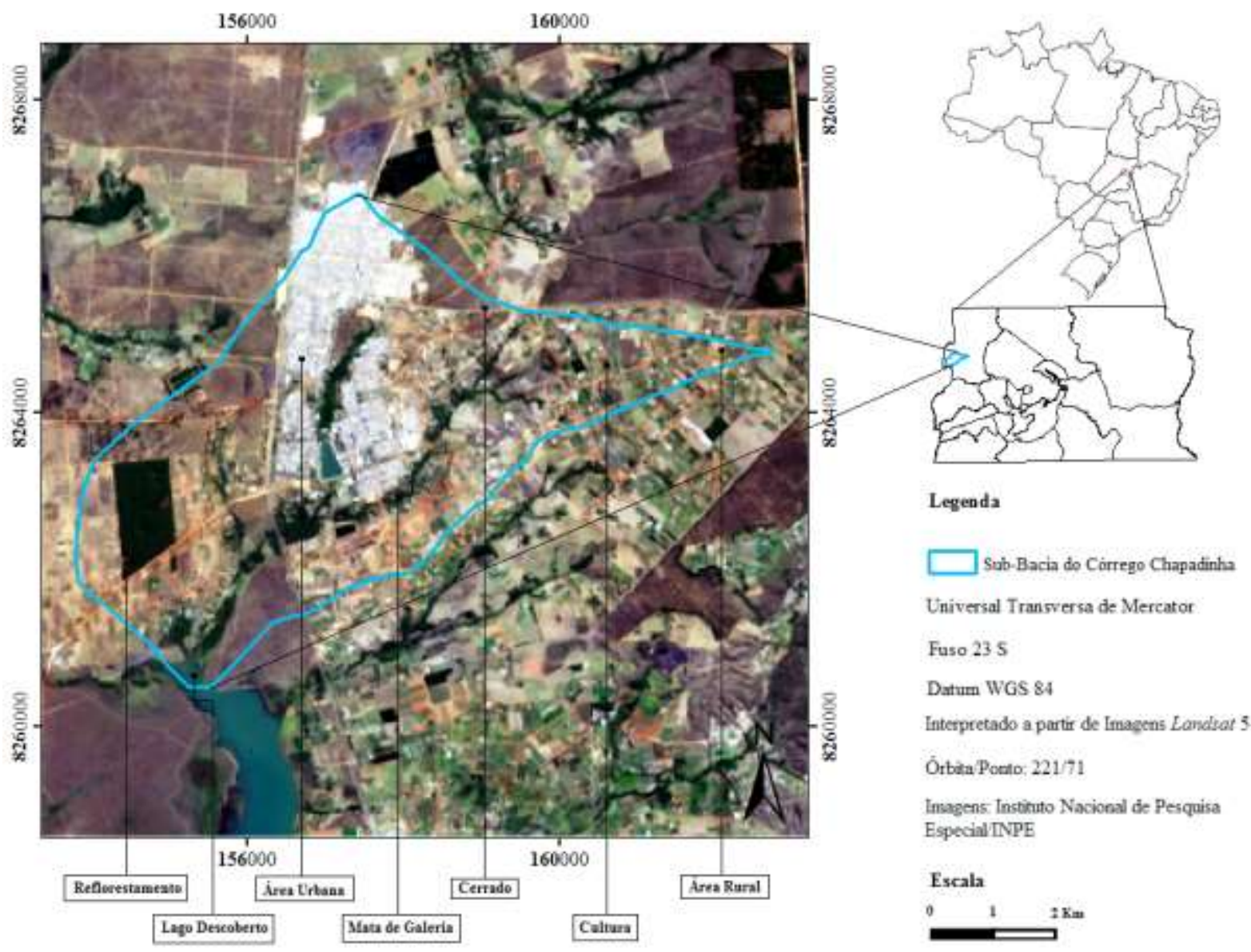

Elaboração: Gilney de Araújo Costa (Programa de Pós-Graduação em Geografia, 2014). 


\subsection{CONTEXTUALIZAÇÃO HISTÓRICA}

O objetivo deste tópico é a contextualização histórica da ocupação da Sub-bacia do Córrego Chapadinha de maneira cronológica, com fatos ocorridos no território da Sub-bacia e outros com ocorrências fora de seu território, mas que influenciam diretamente na formação dos conflitos socioambientais. Além disso, busca-se, ao final, a identificação dos principais conflitos existentes para posteriormente analisá-los.

A história da Sub-bacia do Córrego Chapadinha é a própria história de formação da cidade de Brazlândia, haja vista a cidade ter em torno de 95\% de sua área nesta Sub-bacia, principalmente o setor Tradicional, ponto inicial de formação da cidade.

Conforme as informações coletadas nos arquivos da Administração Regional de Brazlândia - RA IV, os primeiros registros da cidade datam de 1932. Púbio de Souza, o prefeito do município de Santa Luzia, atualmente Luziânia, por meio do Decreto $\mathrm{n}^{\circ} 55$ de 15 de abril de 1932, criou o Distrito de Brazlândia na fazenda Chapadinha, em terras doadas pelos herdeiros de João Braz de Sobrinho, antigo dono da fazenda. A raiz Braz do sobrenome da família, a quem pertencia as terras da região, associada à palavra inglesa "land", aportuguesada, sustentou o topônimo da cidade, devido à relação de respeito que, provavelmente, existiu entre os antigos donos e a comunidade que foi se construindo.

A construção da estrada que ligava a cidade de Anápolis no Estado de Goiás à cidade de Planaltina no DF, passando pelo Distrito de Brazlândia, contribuiu para o surgimento de estabelecimentos comerciais, um grupo escolar composto por 56 alunos, uma pensão, uma capela (São Sebastião), quinze residências com casas de telhas e dezoito residenciais cobertas por palhas ou capim. À época a cidade contava com 113 habitantes.

A cidade foi formada, inicialmente, pelo setor Tradicional em uma área próxima ao córrego Chapadinha e ao córrego Veredinha. As 33 casas e os comércios restringiam-se a área em torno da capela de São Sebastião. Em 05 de junho de 1933, o prefeito de Santa Luzia designou Joaquim Dutra Sobrinho, como o primeiro Subprefeito do distrito (VASCONCELOS, 1988).

De acordo com Vasconcelos (idem), quando o governo do Estado de Goiás começou a intervir na região onde seria Brasília para realizar desapropriações, o engenheiro Joffre Mozart Parada, com o apoio jurídico de Segismundo de Araújo Melo, realizou, a partir de 1956, o levantamento completo das terras de Brazlândia, conhecida como antiga fazenda Chapadinha. 
Em maio de 1958, foram desapropriados mais de mil alqueires num processo de transferência da nova capital do Brasil. Segundo o referido autor, as principais áreas da antiga fazenda Chapadinha foram adquiridas de Benedito Carlos de Oliveira (Bidó), João Braz Pinto, José Braz de Queiroz entre outros. No processo, foram adquiridas mais de $90 \%$ das terras de Brazlândia. Entretanto a área que circundava a sede urbana da cidade não foi transferida pelo proprietário seu Bidó. Tal situação gerou conflitos entre os moradores e o estado (VASCONCELOS, 1988).

Com a mudança da capital, Brazlândia passou a pertencer ao DF. Em 1964, por meio da Lei $\mathrm{n}^{\circ} 4.545$, tornou-se a quarta região administrativa do DF. Em 12 de junho de 1973, por intermédio do Decreto ${ }^{\circ}$ 2.282, assinado pelo então governador, Hélio Prates da Silveira, a sede da região de Brazlândia passou a ser cidade satélite. (Figura 05).

Observa-se que, antes da implantação de Brasília, Brazlândia apresentou taxas de crescimento modestas, características de povoado do interior brasileiro. A área urbana se limitava ao setor Tradicional. Já na área rural as ocupações se restringiam a propriedades situadas às margens do córrego Chapadinha, do Pulador, do Capãozinho e do Veredinha.

A cidade manteve as características de povoado até 1970, quando as terras da região foram incorporadas à NOVACAP. Desde então sua população aumentou consideravelmente, devido à chegada constante de novos migrantes e aos novos loteamentos que abrigaram os moradores transferidos de diversas invasões.

Segundo Chaves (2011), na década 1960, a cidade contava com, aproximadamente, mil habitantes, porém, ao final dessa mesma década o número saltou para mais de 10 mil. Este número está relacionado à implantação de duas mil casas, a fim de assentar moradores provenientes de invasões situadas no Guará, Núcleo Bandeirante e, principalmente da favela do Vietcong localizada entre Brazlândia e Taguatinga. Assim, deu-se origem ao setor Norte e ao setor Sul, com doze novas quadras, sendo nove no setor Norte (1, 2, 3, 4, 5, 6, 8, 10 e 12) e três no setor Sul (1, 2 e 4).

No final da década de 1970, nas porções oeste e sul do território da bacia, 727,37 hectares foram desmatados. Na ocasião, a vegetação nativa foi substituída por pinus ,e eucaliptos. O fato se dá por meio da criação da PROFLORA S.A - Florestamento e Reflorestamento, que tinha como objetivo explorar e estabelecer a política de ocupação de áreas e preservação de encostas e mananciais. O GDF tinha participação no capital social. 
Figura 05 - Localização da Região Administrativa de Brazlândia - RA IV e do Sítio Urbano de Brazlândia.

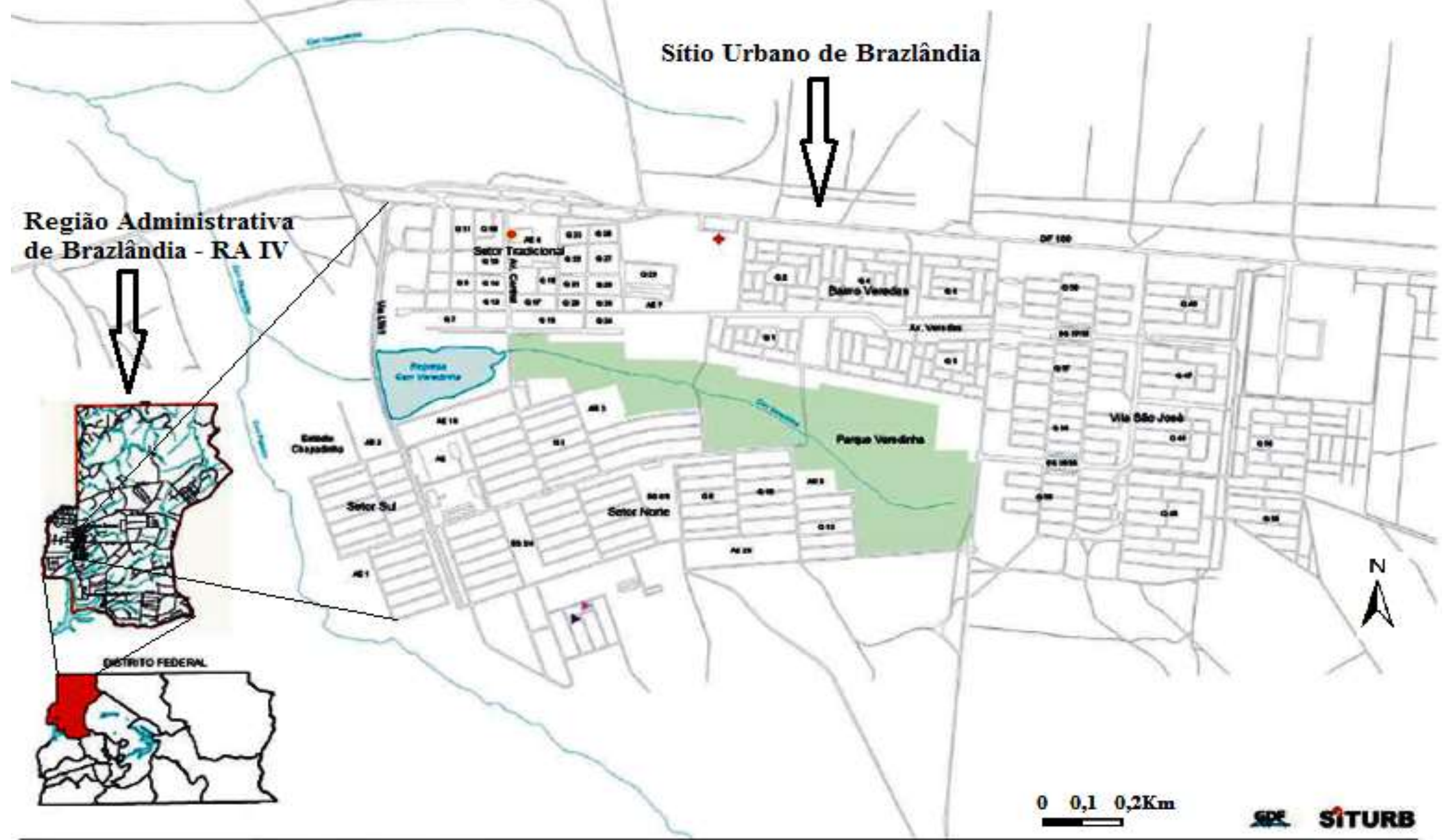

Fonte: COSTA, Graciete Guerra. As regiões Administrativas do Distrito Federal de 1960 a 2011.

Adaptação: Gilney de Araújo Costa (Programa de Pós-Graduação em Geografia, 2014). 
Ainda na década de 1970, uma parte das terras situadas na porção leste do território foi loteada e distribuída mediante Direito de Posse a pequenos produtores rurais pelo Instituto Nacional de Colonização e Reforma Agrária. O loteamento foi denominado setor Chapadinha.

Em meados da década de 1980, a população era de aproximadamente 25 mil, número ligado à construção da Vila São José com quatro quadras 35, 36, 37 e 38. As quadras 35 e 36 foram erguidas em 1982, enquanto que as quadras 37 e 38 foram erguidas em 1984. Todas estabelecidas no governo militar de João Baptista de Oliveira Figueiredo (1979 - 1985).

Em 1983, por intermédio do Decreto Federal nº 88.940, foi criada a Área de Proteção Ambiental da Bacia do Rio Descoberto, com 39100 hectares destinados à proteção das subbacias hidrográficas que compõe a área e principalmente do lago Descoberto. Entre as subbacias, está a Sub-bacia do Córrego Chapadinha (Figura 06).

\section{Figura 06 - Imagem de Localização da APA da Bacia do Rio Descoberto.}

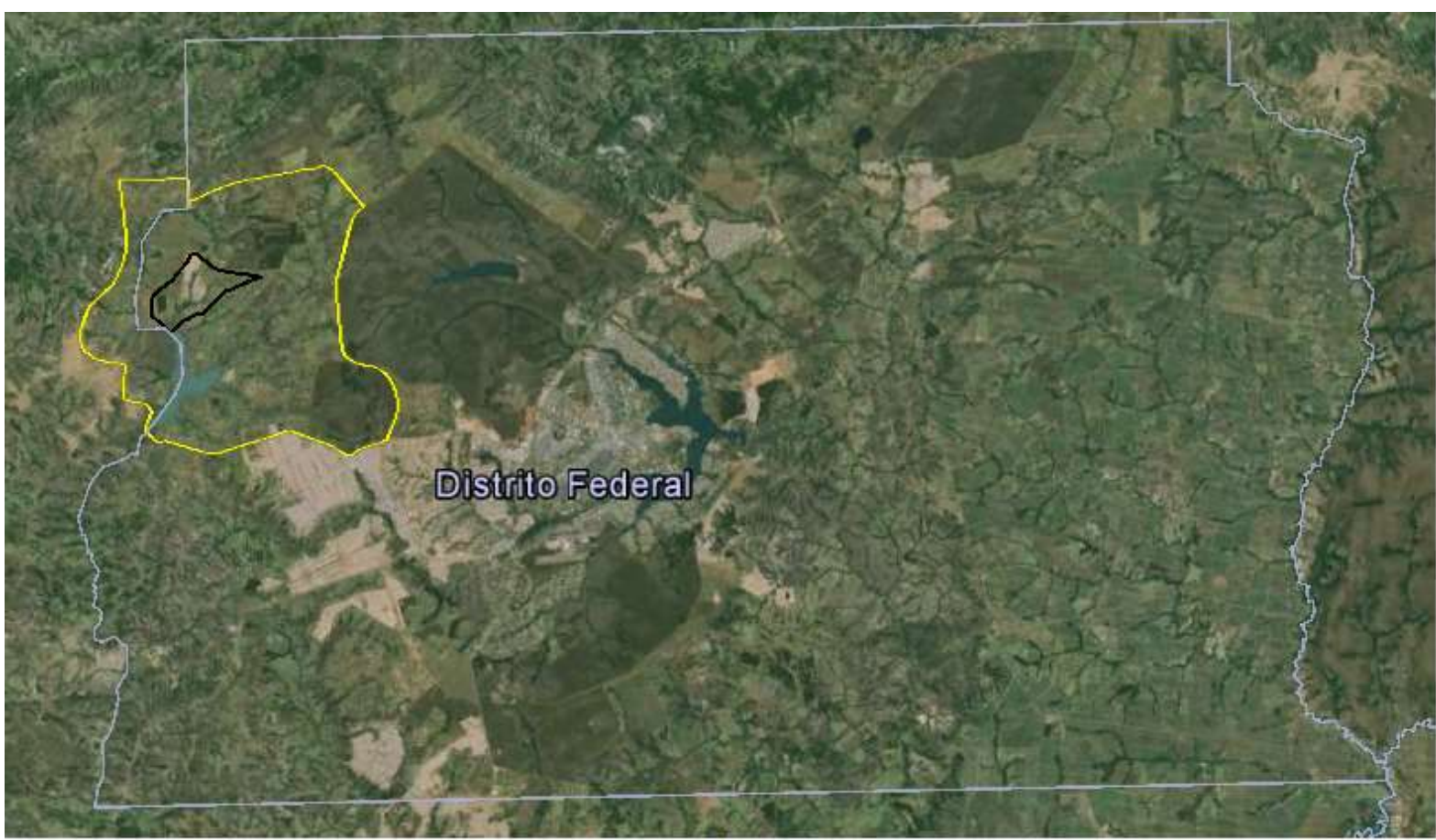

Legenda

Distrito Federal

APA da Bacia do Rio Descoberto Sub-Bacia do Córrego Chapadinha

Fonte: www.icmbio.gov.br/portal/biodiversidade/unidades-de-conservação/biomas-brasileiro/cerrado.html.

Em 1989, a área situada entre o setor Tradicional e a Vila São José foi ocupada por invasores, os quais foram retirados. Nessa época, deu-se o início à distribuição de lotes. Foram contempladas nessa distribuição pessoas cadastradas na extinta Sociedade de 
Habitação de Interesse Social (SHIS) e também funcionários públicos. Inicialmente o setor foi chamado de "Mangue Seco", posteriormente passou a ser denominado de setor Veredas.

Em 1989, o GDF por intermédio da Lei $\mathrm{n}^{\circ} 49$ decidiu extinguir a PROFLORA S.A. Com isso, a TERRACAP assumiu o domínio das terras. Para derrubar os pinus e os eucaliptos, foram contratadas algumas empresas, entre elas Granjas Só Frango LTDA.

Em 1992, a Lei ${ }^{\circ} 302$ autorizou o Poder Executivo a criar e instalar o Parque Ecológico Veredinha. A lei autorizou o Poder Executivo a desapropriar imóveis e benfeitorias particulares existentes na área envolvida pela poligonal delimitadora e a realizar as obras e serviços necessários à implantação do parque.

Nesse sentido, em 1994, em uma área verde situada entre o setor Norte, o setor Veredas, o setor Tradicional e a Vila São José da cidade de Brazlândia, o GDF criou o Parque Ecológico Veredinha (Figura 07), por meio do Decreto $\mathrm{n}^{\circ} 16.052$, o qual regulamentou a Lei

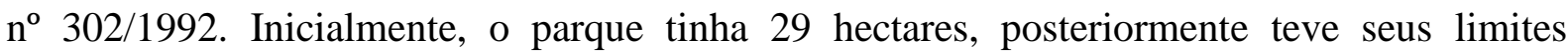
ampliados pela Secretaria de Estado de Administração de Parques e Unidades de Conservação do DF para 57 hectares. A partir de então, deflagrou-se um conflito entre os moradores e o órgão gestor.

\section{Figura 07 - Localização do Parque Ecológico Veredinha/Brazlândia/DF}

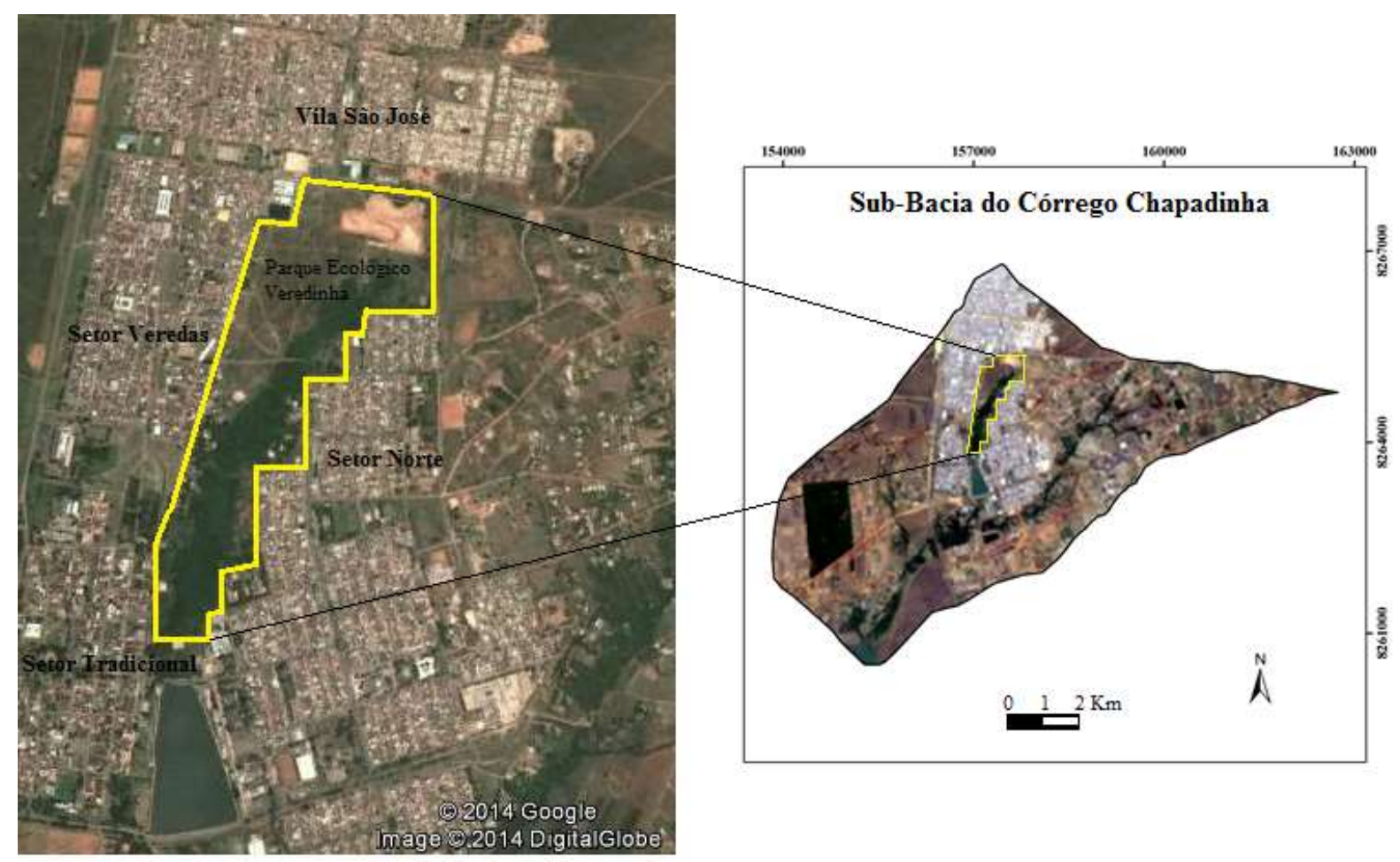

Imagem: Google Earth, 2014.

Elaboração: Gilney de Araújo Costa (Programa de Pós-Graduação em Geografia, 2014). 
Em 1994, a área situada acima da Vila São José ao norte da cidade de Brazlândia foi invadida, dando origem a oito novas quadras $(45,46,47,48,55,56,57$ e 58). Depois da invasão, foi providenciada energia elétrica de modo fraudulento, ou seja, por meio de gambiarras; a água era fornecida por caminhões pipas, que enchiam as caixas d'águas que ficavam em frente aos lotes. Posteriormente, essas quadras foram incorporadas à paisagem urbana, contudo elas carecem de regularização e assim se tornaram mais um caso conflituoso.

Em 1996, nas áreas que foram desmatadas pela PROFLORA S.A no território da bacia surgiram ao mesmo tempo duas invasões (Bela Vista e Maranata), mais tarde denominados de Assentamento Bela Vista e Assentamento Maranata, situados na porção sul e na porção sudoeste, respectivamente.

O Assentamento Bela Vista foi erguido na área conhecida como Cascalheira, cujo nome se referia ao material retirado do solo para ser usado na base de construções e na manutenção de vias não pavimentadas. As casas eram erguidas com lonas e madeiras (Figura 08). Já o Assentamento Maranata foi erguido em uma área às margens da via DF 541 que liga a cidade de Brazlândia a Águas Lindas de Goiás.

\section{Figura 08 - Moradia no Início do Assentamento Bela Vista, em 1996, com Lona e Madeirites.}

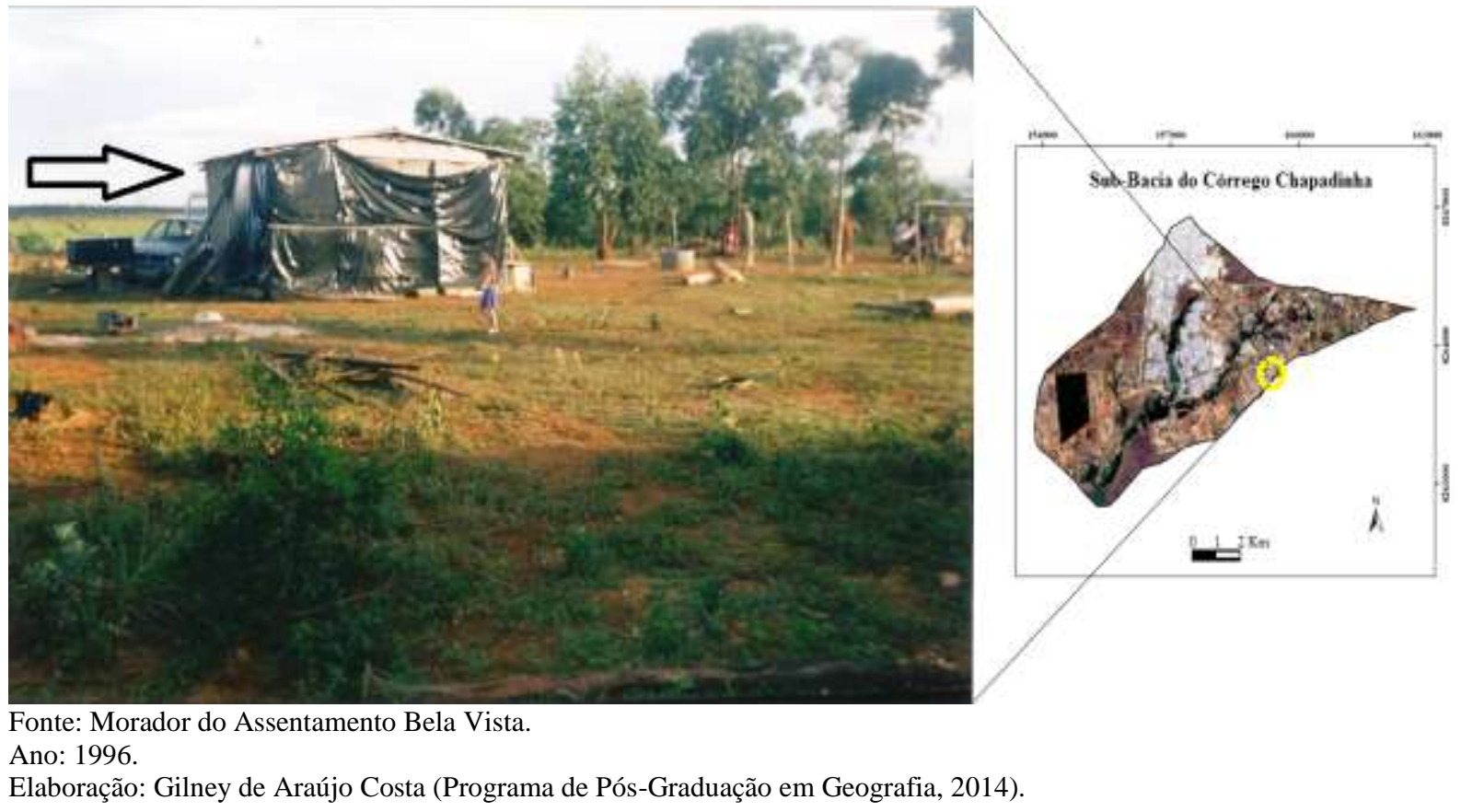


Em 1998, foram realizadas três Audiências Públicas, com a finalidade de discutir com a comunidade em geral da cidade de Brazlândia a desafetação das áreas públicas intersticiais (becos) e a mudança de destinação dos bens públicos de área de uso comum do povo para unidade habitacional. Os becos a serem ocupados estavam localizados no setor Norte, no setor Sul e na Vila São José. Nesse mesmo ano, os becos foram ocupados por servidores das instituições de segurança pública da cidade: Polícia Militar, Corpo de Bombeiro Militar e Polícia Civil.

A ocupação foi uma articulação entre o GDF e a Cooperativa Habitacional dos Servidores de Segurança Pública de Brazlândia (Figura 09). Ao todo foram ocupados 77 becos totalizando 154 lotes: 94 lotes distribuídos aos servidores da Polícia Militar, quarenta lotes distribuídos aos servidores do Corpo de Bombeiros Militar e vinte lotes aos servidores da Polícia Civil. Apesar de terem sido distribuídos com anuência do GDF, esses imóveis ficaram desprovidos de escrituras. Dessa forma, configurou-se um conflito entre os moradores e o GDF.

\section{Figura 09 - Cristovam Buarque e o Presidente da Cooperativa e Construção de Residência em um Beco de Brazlândia.}

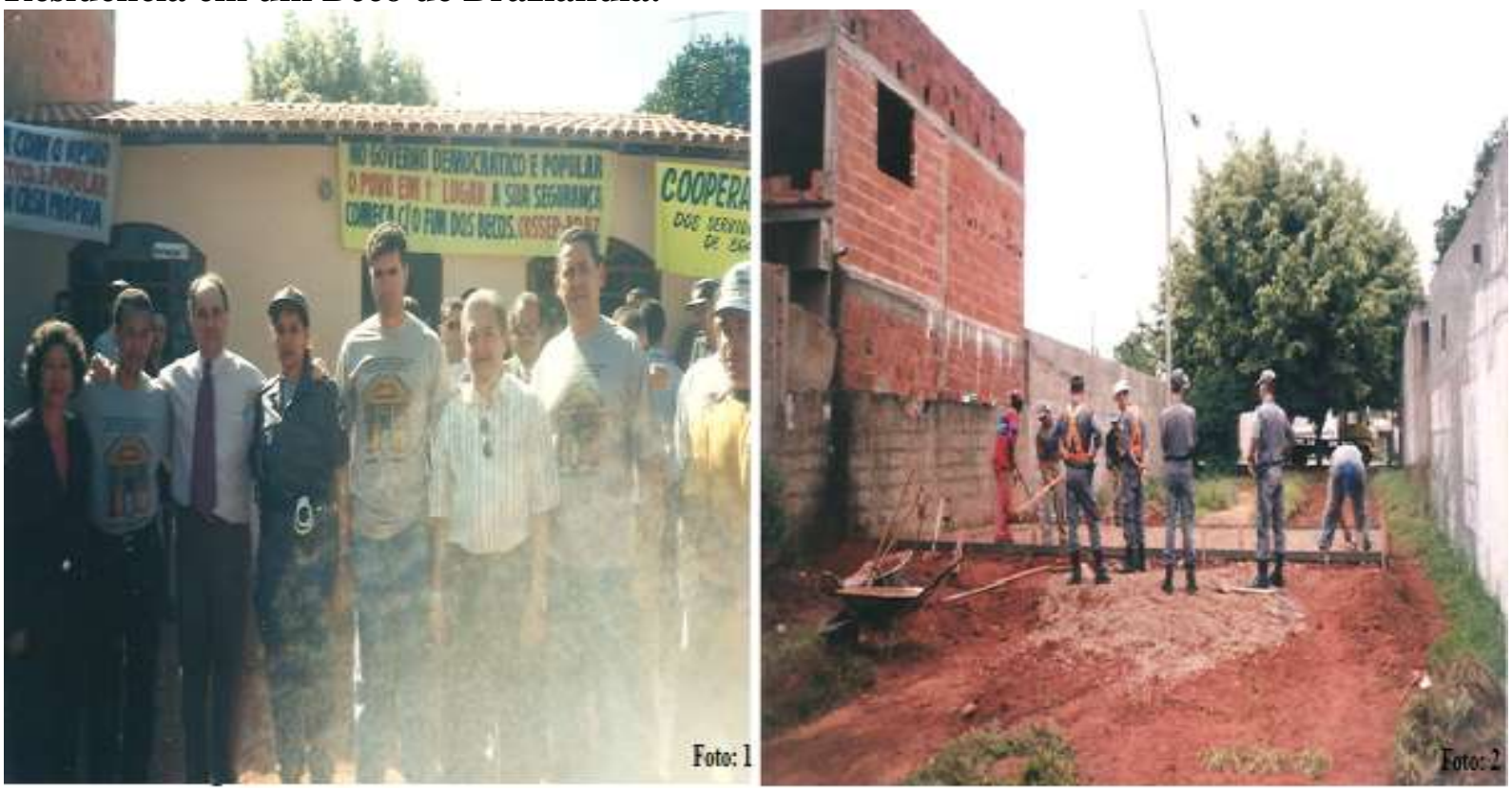

Fonte: Arquivo da Cooperativa Habitacional dos Servidores de Segurança Pública de Brazlândia. Ano: 1998. 
No dia 4 de maio de 1998, foi acordado entre a TERRACAP, a Fundação Zoobotânica do DF e o IBAMA, com participação do Ministério Público Federal e do MPDFT, o Termo de Ajustamento de Conduta, a partir do qual se previa a criação da Floresta Nacional de Brasília. Nesse sentido, em 10 de junho de 1999, foi publicado o decreto presidencial sem número, que criou a Floresta Nacional de Brasília (Figura 10). O decreto dividiu a Floresta em quatro áreas e autorizou a TERRACAP a doar à União a área da unidade.

É necessário mencionar que a criação da Floresta Nacional de Brasília exigiu a desapropriação dos imóveis pertencentes a particulares, mesmo que esses tivessem a posse da terra, mediante escrituração ou outros documentos pertinentes. Nesse sentido, parte da Floresta Nacional de Brasília (FLONA 3) englobou o Assentamento Maranata e o setor Capãozinho. Tal fato causou conflitos entre os moradores e o IBAMA.

\section{Figura 10 - Imagem de Localização da Floresta Nacional de Brasília}

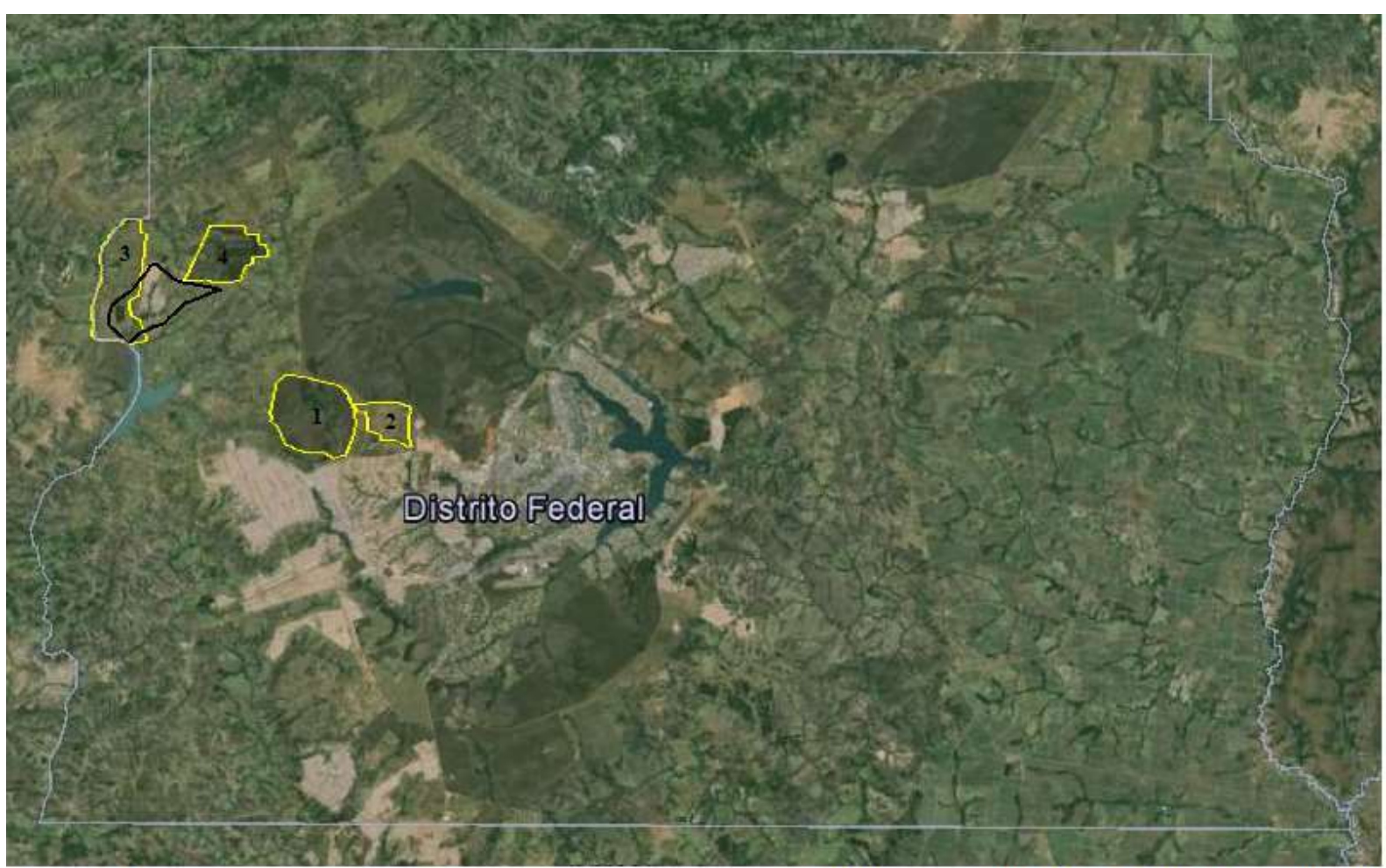

Legenda

Distrito Federal

Floresta Nacional de Brasília
Divisão da Floresta Nacional de Brasília

1 Flona $1 \quad 3$ Flona 3

2 Flona $2 \quad 4$ Flona 4

\section{Sub-Bacia do Córrego Chapadinha}

Fonte: www.icmbio.gov.br/portal/biodiversidade/unidades-de-conservação/biomas-brasileiros/flona-de-brasília.html. 
Figura 11 - Invasão na Quadra 55 no Novo Assentamento, Antes do Incêndio, e depois do Incêndio, e Estruturação das Quadras 33 e 34 da Vila São José Brazlândia/DF.

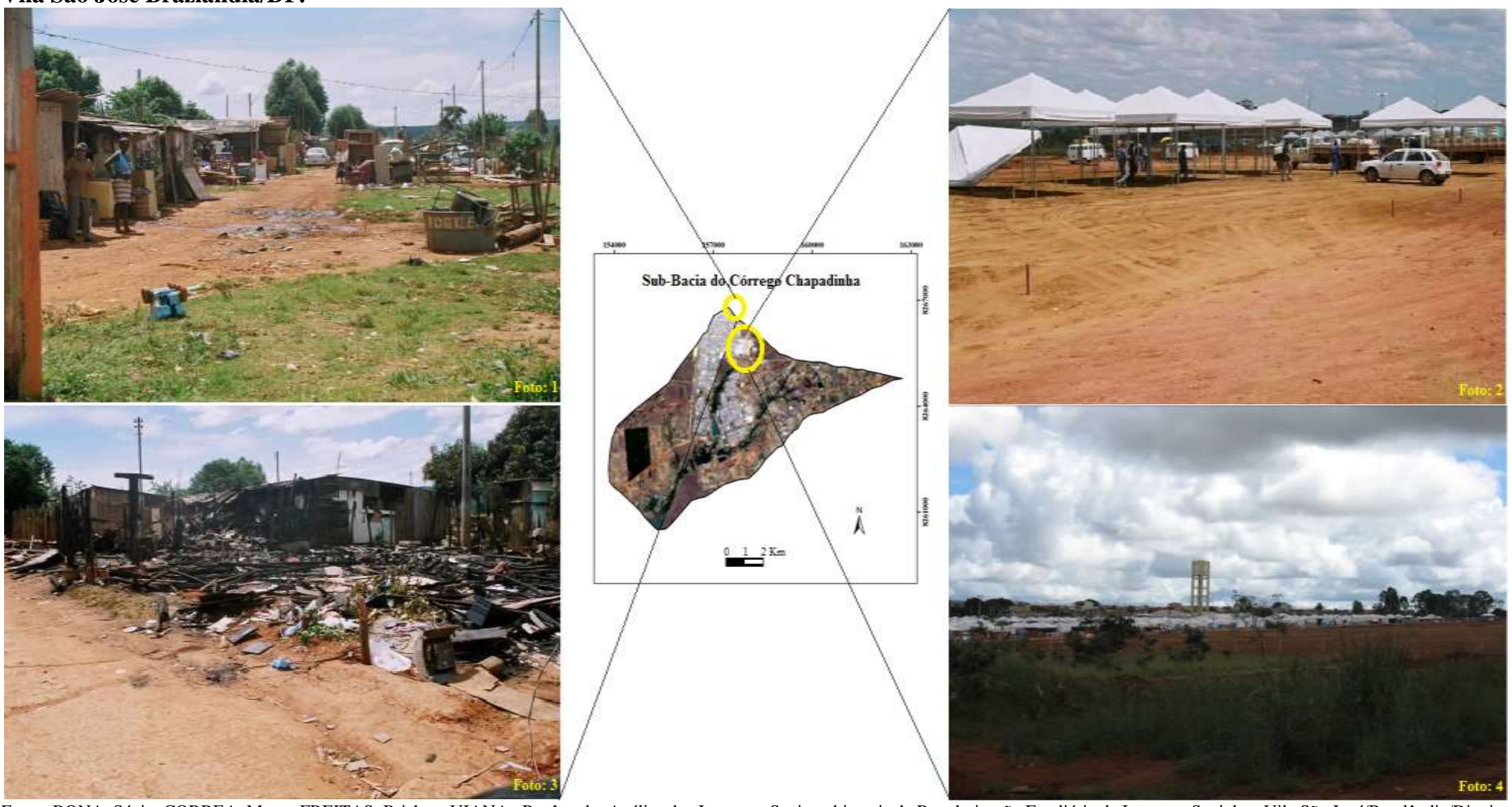

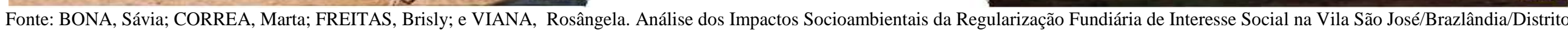
Federal. XVI Encontro Nacional dos Geógrafos Realizado de 25 a 31 de julho de 2010, Porto Alegre - RS.

Elaboração: Gilney de Araújo Costa (Programa de Pós-Graduação em Geografia, 2014). 
Em 2009, foi registrado um dos últimos acontecimentos relacionados a ocupação do território da Sub-bacia do Córrego Chapadinha. Naquele ano, um incêndio devastou uma invasão que ficava próxima a quadra 55 do Novo Assentamento (Fotos 1 e 3 da Figura 11), queimando, praticamente, todos os barracos. Esse fato levou o GDF a estruturar, em caráter de urgência, duas novas quadras (33 e 34), sem levar em consideração os trâmites legais como estudo urbanístico e licenciamento ambiental. As famílias afetadas pelo incêndio foram alojadas em tendas (Fotos 2 e 4 da Figura 11) até a construção de suas moradias. Estas foram construídas por meio de ajuda financeira concedida pelo GDF. Além das famílias afetadas pelo incêndio, foram contempladas outras famílias inscritas em programas de moradia do GDF.

Destarte a contextualização histórica revelou que a ocupação do território da Sub-bacia do Córrego Chapadinha, até a década de 1980, ocorreu de certa forma ordenada, com planejamento de áreas destinadas a comércio, a residência e, em alguns casos, com implantação de infraestruturas antes mesmo da chegada dos futuros moradores. Contudo, a partir da década de 1990, desencadeou-se uma série de ocupações irregulares. Dessa maneira surgiram novos assentamentos, entre eles o Novo Assentamento, em 1994; Assentamento Bela Vista e o Assentamento Maranata, em 1996; as residências nos lotes de becos, em 1998; e as quadras 33 e 34 da Vila São José, em 2009. Salienta-se que, em 1994 e 1999, foram criados o Parque Ecológico Veredinha e a Floresta Nacional de Brasília, respectivamente. A criação dessas áreas demandou a desapropriação dos imóveis. Isso também gerou conflito.

Salienta-se que, para efeito de análise dos conflitos que envolvem a área urbana de Brazlândia - Novo Assentamento, lotes nos antigos becos e as quadras 33 e 34 da Vila São José - foram considerados como um único conflito, pois essas áreas compartilham o mesmo interesse - escrituração dos imóveis - e envolvem basicamente os mesmos atores: moradores e a Companhia de Desenvolvimento Habitacional do Distrito Federal, conforme será visto nos tópicos 3.4 e 3.5.4 desta dissertação. Nesse sentido, foram então identificados quatro casos de conflitos socioambientais, a saber:

1) Parque Ecológico Veredinha;

2) Assentamento Maranata e setor Capãozinho;

3) Assentamento Bela Vista;

4) Novo Assentamento, lotes nos antigos becos e as quadras 33 e 34 da Vila São José.

A seguir a Figura 12 evidencia a localização dos principais conflitos socioambientais identificados. 
Figura 12 - Imagem dos Principais Conflitos Socioambientais no Território da Sub-Bacia do Córrego Chapadinha/Brazlândia/DF.

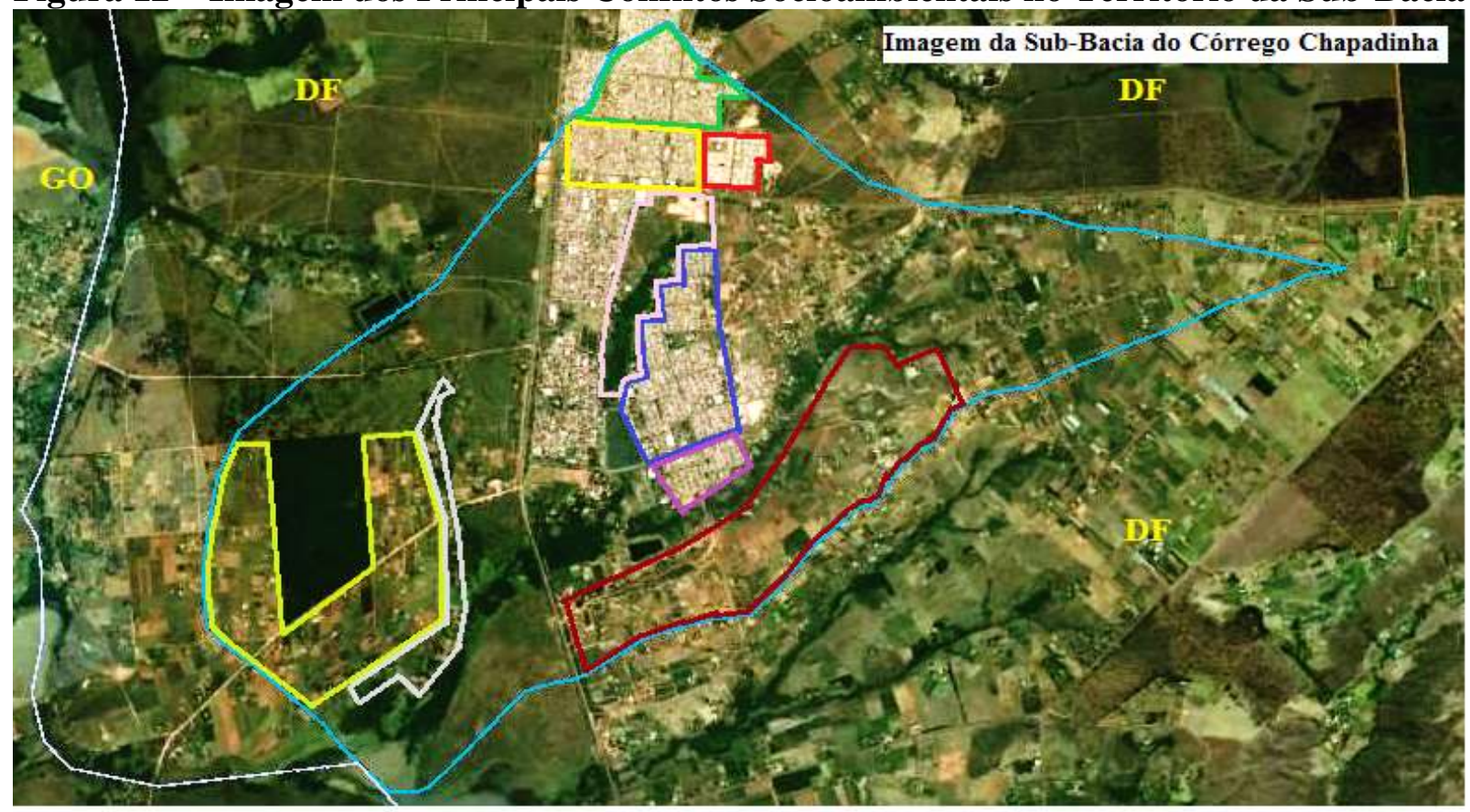

\section{Legenda}

Divisa Entre o Estado de Goiás e o Distrito Federal

Sub-Bacia do Córrego Chapadinha

\section{Áreas Rurais}

Assentamento Maranata

Setor Capãozinho

Assentamento Bela Vista

Parque Ecológico Veredinha

\section{Áreas Urbanas}

Novo Assentamento (quadras 45 a 48 e 55 a 58 )

$\square$ Vila São José (quadra 33 e 34)

Setor Norte (lotes nos antigos becos)

Setor Sul (lotes nos antigos becos)

Vila São José (lotes nos antigos becos, da quadra 35 a 38)

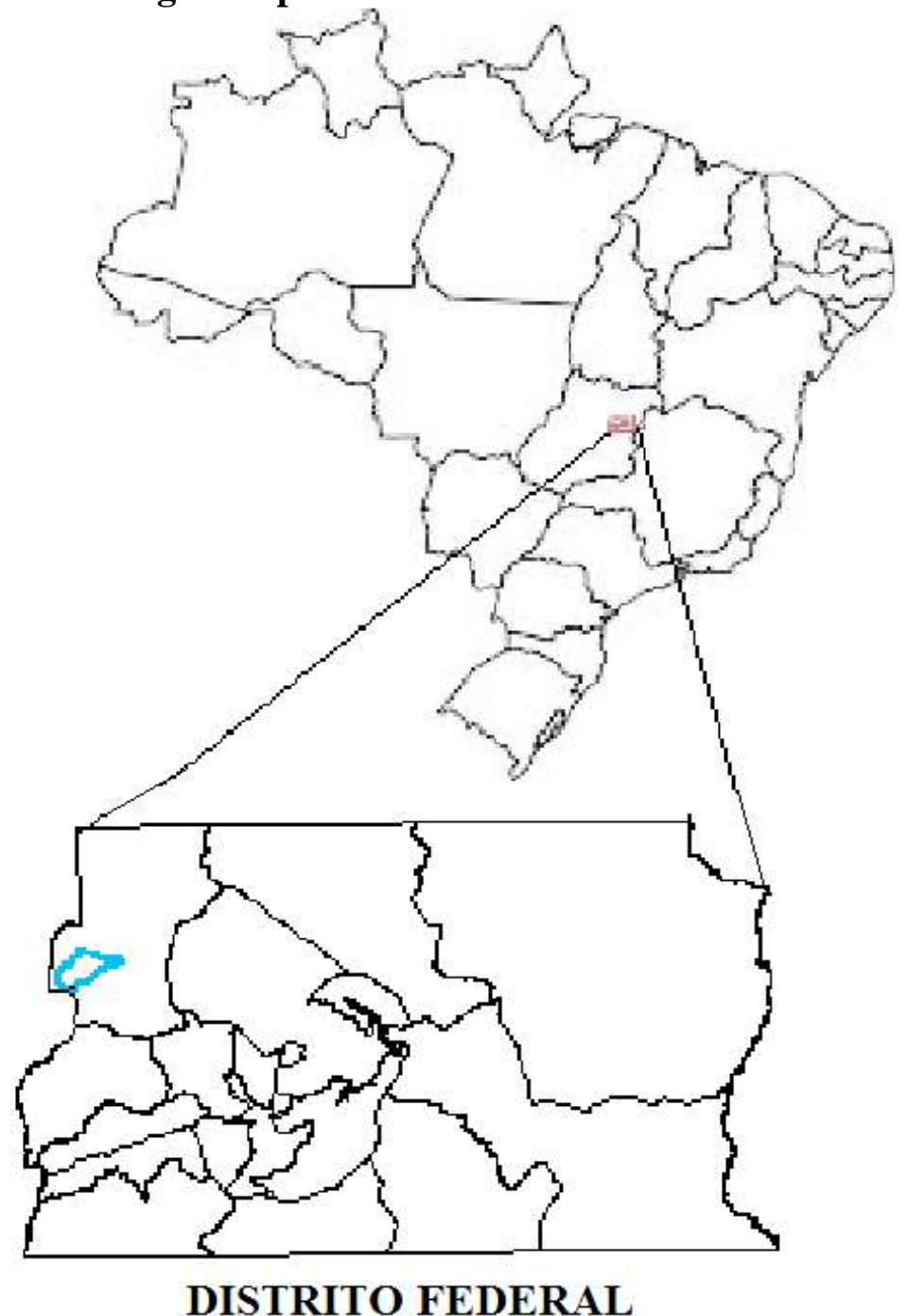

DISTRITO FEDERAL

Imagem: Google Earth, 2014

Elaboração: Gilney de Araújo Costa (Programa de Pós-Graduação em Geografia, 2014). 


\subsection{MAPEAMENTO DA DINÂMICA DO USO DO TERRITÓRIO}

Como critério importante de análise da dinâmica do uso do território da Sub-bacia do Córrego Chapadinha, foi realizado o mapeamento em escala temporal, nos anos de 1984, 1994, 2004 e 2011, tempo que perfaz um recorte temporal de 27 anos. Para tanto, gerou-se a quantificação, demonstrando as transformações das classes propostas no procedimento metodológico tópico 1.5.2 desta dissertação, a saber:

1) Mata de Galeria: caracteriza-se pela formação vegetal que acompanha os rios de pequeno porte e córregos, formando corredores fechados sobre o curso d'água;

2) Reflorestamento: corresponde a área com plantios homogêneos de pinus e eucaliptos;

3) Área Urbana com Alta Densidade: compreende todas as áreas urbanas consolidadas, estruturadas por edificações e sistema viário, onde predominam as superfícies artificiais;

4) Pastagem: compreende as áreas em que a vegetação original teve as suas características alteradas, principalmente com a introdução de plantas exóticas como capim brachiaria;

5) Cerrado: caracteriza-se pela presença de árvores baixas e irregulares, essa formação apresenta algumas espécies com órgãos subterrâneos perenes, que permitem o rebroto após a queima ou corte;

6) Campo Limpo: caracteriza-se pelo tipo de vegetação, predominantemente, herbácea, com raros arbustos e ausência de árvores;

7) Cultura: compreende todas as áreas ocupadas por culturas intensivas, áreas irrigadas, chácaras e setores habitacionais ainda não consolidados caracterizados pela coexistência de atividades agrícolas;

8) Lagos: correspondem aos espelhos d'águas artificiais.

Observa-se que o ano de 1984 foi considerado chave para o início do mapeamento, tendo em vista que o processo de uso do território da Sub-bacia se intensificou a partir da década de 1990. A título de facilitar a compreensão da dinâmica do uso do território, as quantificações encontradas na presente pesquisa foram expressas em hectares e em porcentagem (Tabela 02). Por fim, foi analisada a variação das classes, na tentativa de expressar o que aumentou e o que diminuiu entre os períodos. Frisa-se que a análise sempre buscou as influências dos conflitos socioambientais identificados na dinâmica do uso do território da Sub-bacia do Córrego Chapadinha. 
Figura 13 - Mapas do Uso do Território da Sub-Bacia do Córrego Chapadinha/Brazlândia/DF - 1984, 1994, 2004 e 2011.

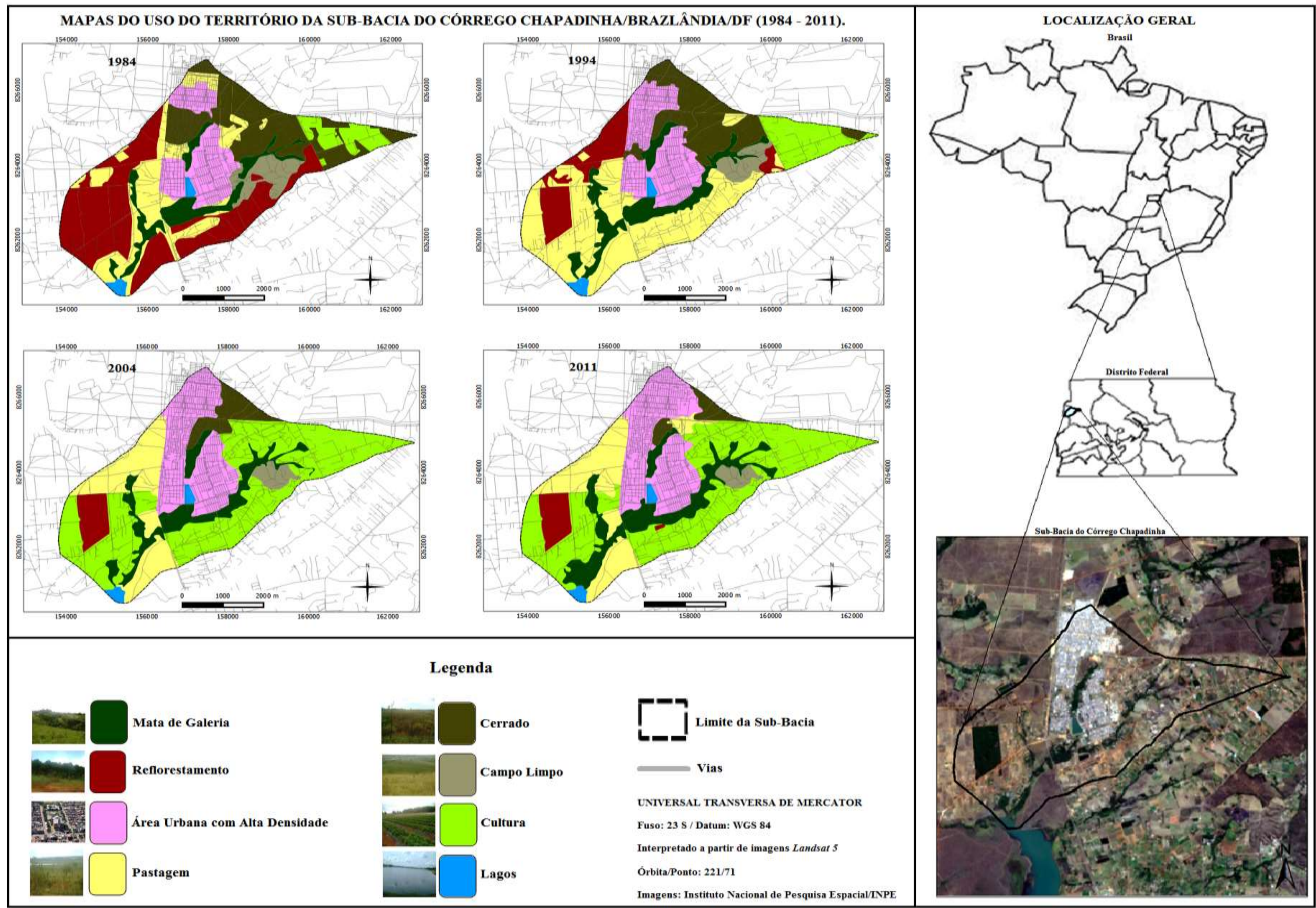


Tabela 02 - Quantificação das Classes do Uso do Território na Sub-Bacia do Córrego Chapadinha (hectares) e (\%) $1984-2011$

\begin{tabular}{|c|c|c|c|c|c|c|c|c|}
\hline \multirow[b]{2}{*}{ Classes } & \multicolumn{2}{|c|}{1984} & \multicolumn{2}{|c|}{1994} & \multicolumn{2}{|c|}{2004} & \multicolumn{2}{|c|}{2011} \\
\hline & (hectares) & $(\%)$ & (hectares) & $(\%)$ & (hectares) & $(\%)$ & (hectares) & $(\%)$ \\
\hline $\begin{array}{l}\text { Mata de Galeria: compreende a formação vegetal que } \\
\text { acompanha os rios de pequeno porte e córregos, } \\
\text { formando corredores fechados sobre o curso d'água; }\end{array}$ & 197,63 & 8,45 & 254,93 & 10,90 & 246,97 & 10,56 & 313,16 & 13,39 \\
\hline $\begin{array}{l}\text { Reflorestamento: corresponde a área com plantios } \\
\text { homogêneos de pinus e eucaliptos; }\end{array}$ & 727,37 & 31,10 & 249,08 & 10,65 & 94,96 & 4,05 & 97,06 & 4,15 \\
\hline $\begin{array}{l}\text { Área Urbana com Alta Densidade: compreende } \\
\text { todas as áreas urbanas consolidadas, estruturadas por } \\
\text { edificações e sistema viário, onde predominam as } \\
\text { superfícies artificiais; }\end{array}$ & 309,66 & 13,24 & 384,73 & 16,45 & 456,77 & 19,53 & 495,83 & 21,20 \\
\hline $\begin{array}{l}\text { Pastagem: compreende as áreas em que a vegetação } \\
\text { original teve as suas características alteradas, } \\
\text { principalmente com a introdução de plantas exóticas } \\
\text { como capim brachiaria; }\end{array}$ & 393,62 & 16,83 & 797,77 & 34,11 & 337,95 & 14,45 & 357,83 & 15,30 \\
\hline $\begin{array}{l}\text { Cerrado: caracteriza-se pela presença de árvores } \\
\text { baixas e irregulares, essa formação apresenta algumas } \\
\text { espécies com órgãos subterrâneos perenes, que } \\
\text { permitem o rebroto após a queima ou corte; }\end{array}$ & 462,85 & 19,79 & 357,63 & 15,29 & 121,38 & 5,19 & 67,12 & 2,87 \\
\hline $\begin{array}{l}\text { Campo Limpo: caracteriza-se pelo tipo de vegetação, } \\
\text { predominantemente, herbácea, com raros arbustos e } \\
\text { ausência de árvores; }\end{array}$ & 108,98 & 4,66 & 75,54 & 3,23 & 52,63 & 2,25 & 45,15 & 1,93 \\
\hline $\begin{array}{l}\text { Cultura: compreende todas as áreas ocupadas por } \\
\text { culturas intensivas, áreas irrigadas, chácaras e setores } \\
\text { habitacionais ainda não consolidados caracterizados } \\
\text { pela coexistência de atividades agrícolas; }\end{array}$ & 113,45 & 4,85 & 192,72 & 8,24 & 1003,83 & 42,92 & 938,82 & 40,14 \\
\hline Lagos: correspondem aos espelhos d'águas artificiais. & 25,26 & 1,08 & 26,42 & 1,13 & 24,33 & 1,04 & 23,85 & 1,02 \\
\hline Total & 2338,82 & 100 & 2338,82 & 100 & $\mathbf{2 3 3 8 , 8 2}$ & 100 & $\mathbf{2 3 3 8 , 8 2}$ & 100 \\
\hline
\end{tabular}




\subsubsection{MATA DE GALERIA}

O mapeamento revelou que, em 1984, a Mata de Galeria ocupava 197,63 hectares da área total do território da Sub-bacia do Córrego Chapadinha. Em 1994, cobria 254,93 hectares e em 2004 caiu para 246,97 hectares. Contudo, em 2011, representou 313,16 hectares (Tabela 02). O Gráfico 02 descreve a variação em hectares. Observa-se que, no período entre 1984 e 1994, foram acrescentados 57,30 hectares. Esse valor está associado à criação do Parque Ecológico Veredinha (Lei $n^{\circ}$ 302/1992 e Decreto $n^{\circ}$ 16.052/1994). No período entre 1994 e 2004, a área diminuiu 7,96 hectares, que está relacionada à expansão urbana no perímetro do Parque Ecológico Veredinha, próximo a quadra 1 do Setor Veredas. Porém, no período entre 2004 a 2011, houve um aumento de 66,19 hectares, principalmente das matas próximas ao lago Descoberto. Nesse período, o ICMBio intensificou a fiscalização por meio das empresas de vigilância Ipanema e Santa Helena. A partir dessa fiscalização, coibiram-se as invasões na Floresta Nacional de Brasília e, consequentemente, o desmatamento.

Gráfico 02 - Variação da Mata de Galeria no Território da Sub-Bacia do Córrego Chapadinha (hectares). 1984-2011.

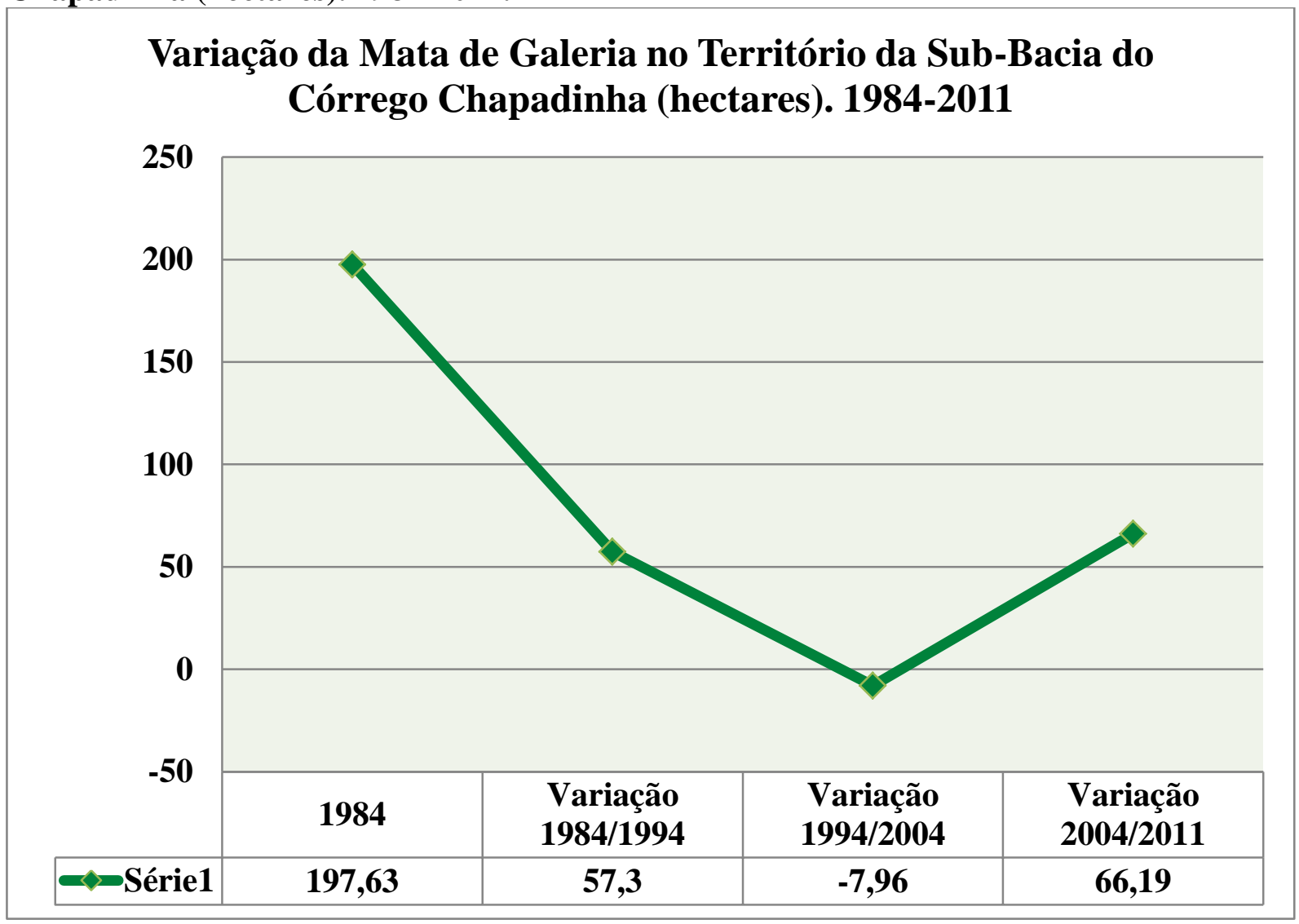




\subsubsection{REFLORESTAMENTO}

A classe de reflorestamento está associada ao plantio de pinus e eucalipto realizado pela PROFLORA S.A, no final da década de 1970 e início da década de 1980. Dessa forma, em 1984 o reflorestamento ocupava 727,37 hectares da área total do território da Sub-bacia em tela, representando 31,10\% (Tabela 02). De 1984 a 2004 segue uma trajetória de redução, em 1994 representava 10,65\% e em 2004, 4,06\%. Em 2011, passou a ocupar 4,15\% da área pesquisada. Salienta-se que a redução, no período entre 1984 a 2004, ocorre em função da extinção da PROFLORA S.A, em 1989, e o desmatamento realizado por empresas como a Granja Só Frango LTDA. Por meio da análise do Gráfico 03, percebe-se que, no período entre 1984 e 1994, a variação foi 478,29 hectares de redução; entre 1994 e 2004, a redução foi de 154,12 hectares, já no período correspondente a 2004 e 2011 a área teve um acréscimo de 2,10 hectares, ocupando, assim 97,06 hectares da área total do território (Tabela 02). Conforme análise realizada na Figura 13, a variação do período de 2004 a 2011 está relacionada ao plantio promovido por particular em uma propriedade situada às margens do córrego Pulador, próximo a via BR 080.

Gráfico 03 - Variação do Reflorestamento no Território da Sub-Bacia do Córrego Chapadinha (hectares). 1984-2011.

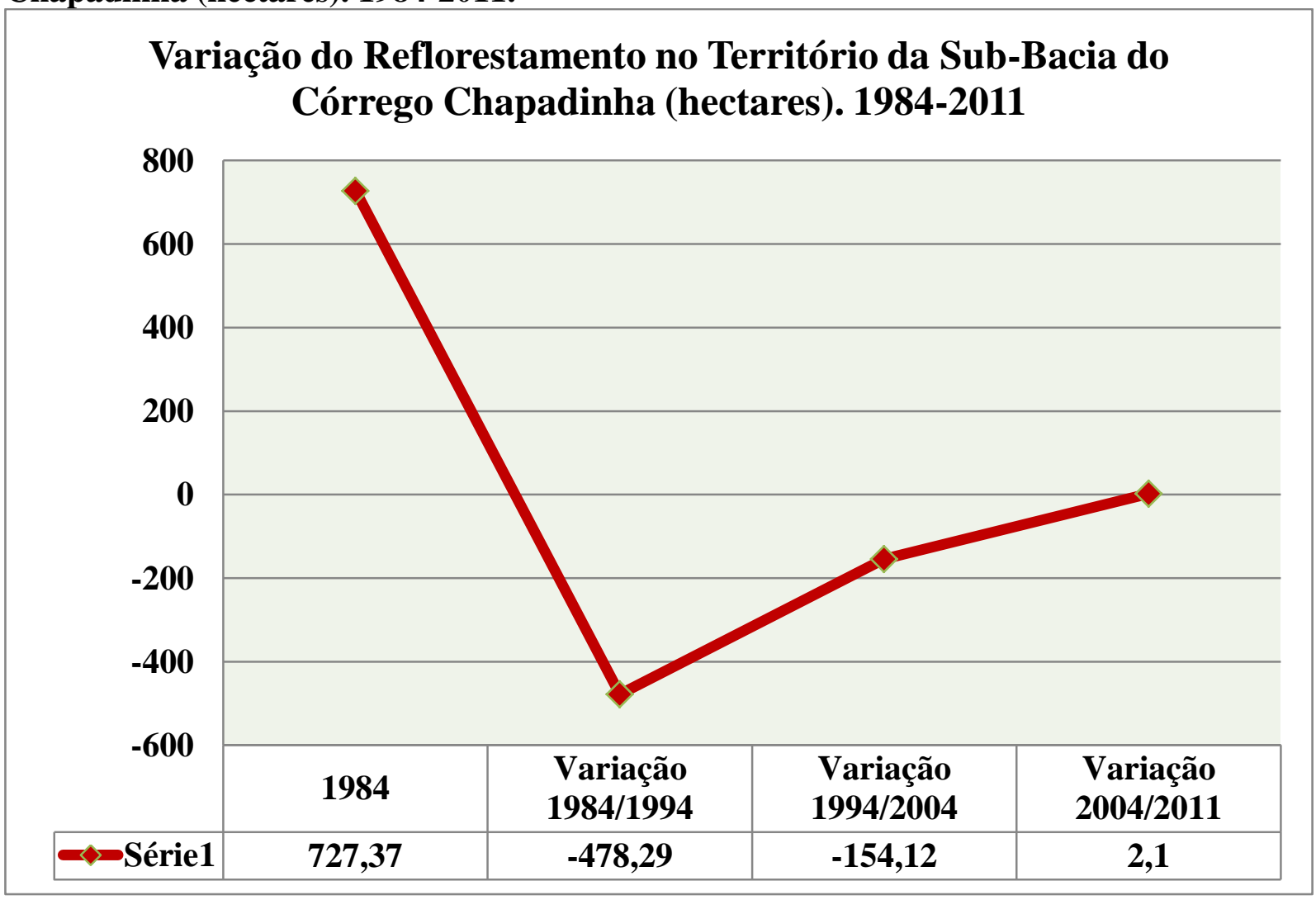




\subsection{3 ÁREA URBANA COM ALTA DENSIDADE}

Com base no mapeamento, ficou claro que, no recorte temporal pesquisado, entre 1984 - 2011, a área urbana com alta densidade teve um acréscimo considerável, que está relacionado às ocupações irregulares, as quais, por sua vez, deram origem ao Novo Assentamento, em 1994, e as quadras 33 e 34 da Vila São José, em 2009. Em 1984, a área era de 309,66 hectares, em 1994 era de 384,73 hectares, em 2004 era de 456,77 hectares e em 2011 495,83 hectares (Tabela 02). Em porcentagem, representava 13,24\% em 1984; 16,45\% em 1994; 19,53\% em 2004 e 21,20\% em 2011 da área total do território da Sub-bacia do Córrego Chapadinha (Tabela 02). No que tange à variação, entre 1984 e 1994, foram 75,07 hectares de acréscimo; de 1994 a 2004, 72,04 hectares e, entre 2004 a 2011, o acréscimo de foi de 39,06 hectares (Gráfico 04).

Gráfico 04 - Variação da Área Urbana com Alta Densidade no Território da Sub-Bacia do Córrego Chapadinha (hectares). 1984-2011.

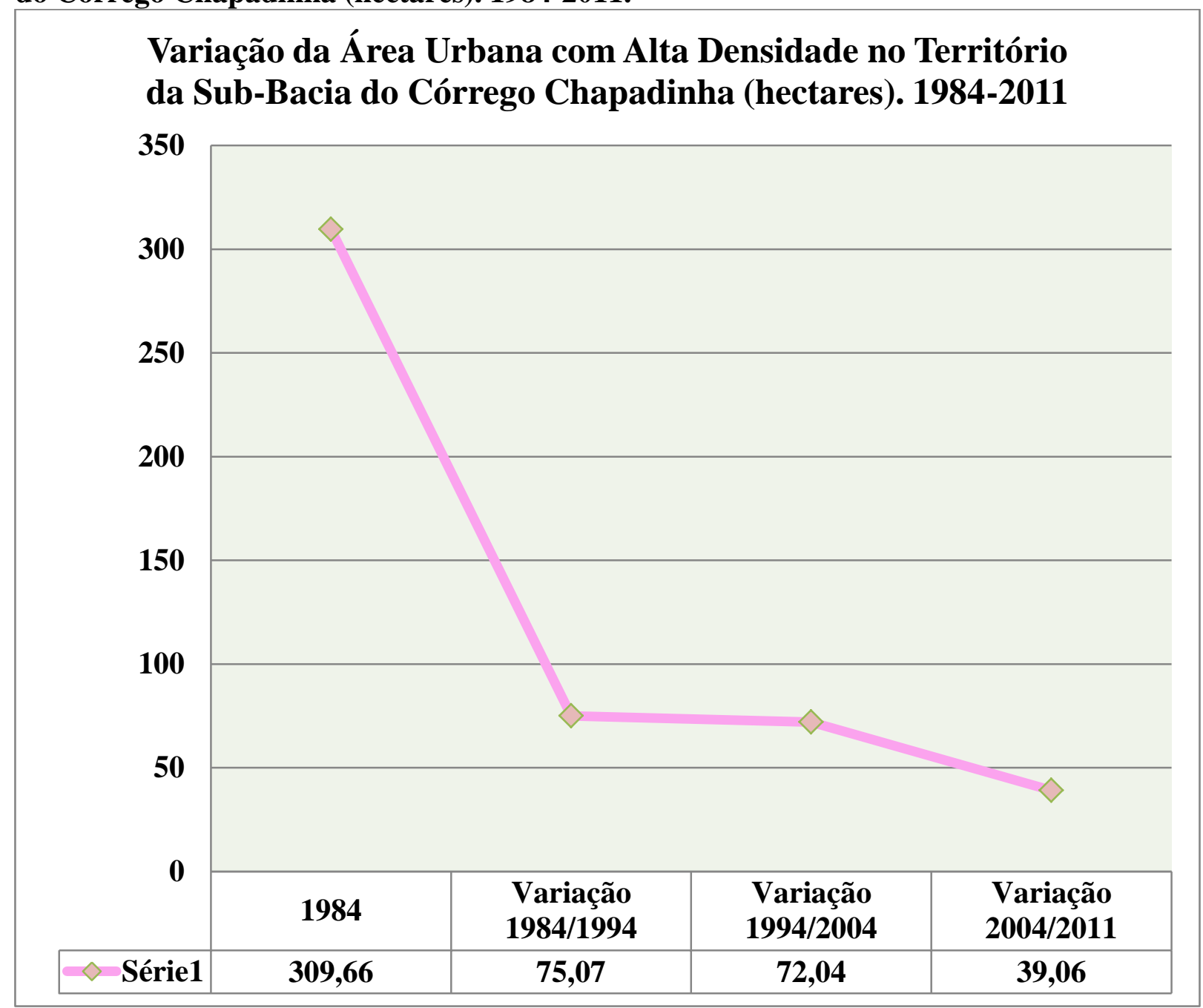




\subsubsection{PASTAGEM}

Em 1984, ano em que iniciou o mapeamento, a pastagem representava 393,62 hectares; em 1994, 797,77 hectares; em 2004, 337,95 hectares; e em 2011 ocupava 357,83 hectares (Tabela 02). Verifica-se, no Gráfico 05, que, no período entre 1984 e 1994, a variação foi de 404,15 hectares. Esse período coincide com o desmatamento da classe de reflorestamento, que depois da retirada das madeiras (pinus e eucaliptos) adquiriu característica de pastagem. Em 2004 e 2011, a variação foi de 459,82 hectares para menos. Nesse período, grande parte dessa classe foi substituída por áreas agrícolas, onde estão localizados o Assentamento Maranata e o Assentamento Bela Vista. As parcelas que ainda restam estão situadas na Floresta Nacional de Brasília, às margens da via BR 080.

Gráfico 05 - Variação da Pastagem no Território da Sub-Bacia do Córrego Chapadinha (hectares). 1984-2011.

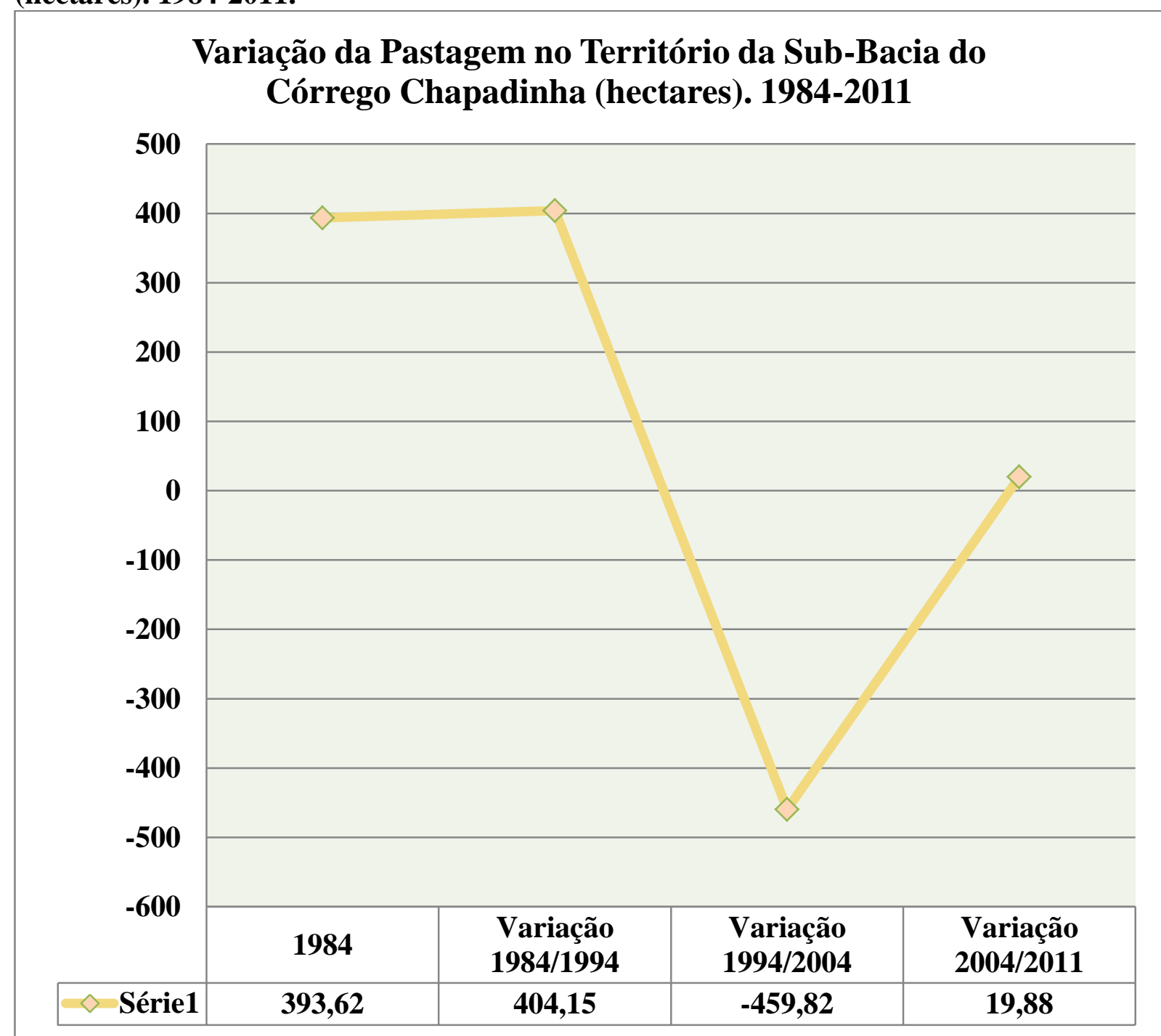




\subsubsection{CERRADO}

O Cerrado sofreu bastante com a intervenção do homem. Com o mapeamento, percebeu-se a redução constante. Conforme a Tabela 02, o Cerrado representava a segunda maior classe em 1984 com 462,85 hectares, equivalente a 19,79\%; em 1994, a sua área foi reduzida para 357,63 hectares; em 2004, caiu para 121,38 hectares e, em 2011, reduziu-se para 67,12 hectares, equivalendo-se a 2,87\% da área total do território da Sub-bacia do Córrego Chapadinha. A redução constante do Cerrado ocorre devido, principalmente, à expansão urbana com a formulação do setor Veredas, do Novo Assentamento e das quadras 33 e 34 da Vila São José. Pelo exposto no Gráfico 06, a variação de 1984 a 1994 foi de 105,22 hectares; entre 2004 e 2011, foi de 7,48 de perda. Uma pequena parcela ainda é conservada no Parque Ecológico Veredinha, próximo a quadra 33 da Vila São José.

Gráfico 06 - Variação do Cerrado no Território da Sub-Bacia do Córrego Chapadinha (hectares). 1984-2011.

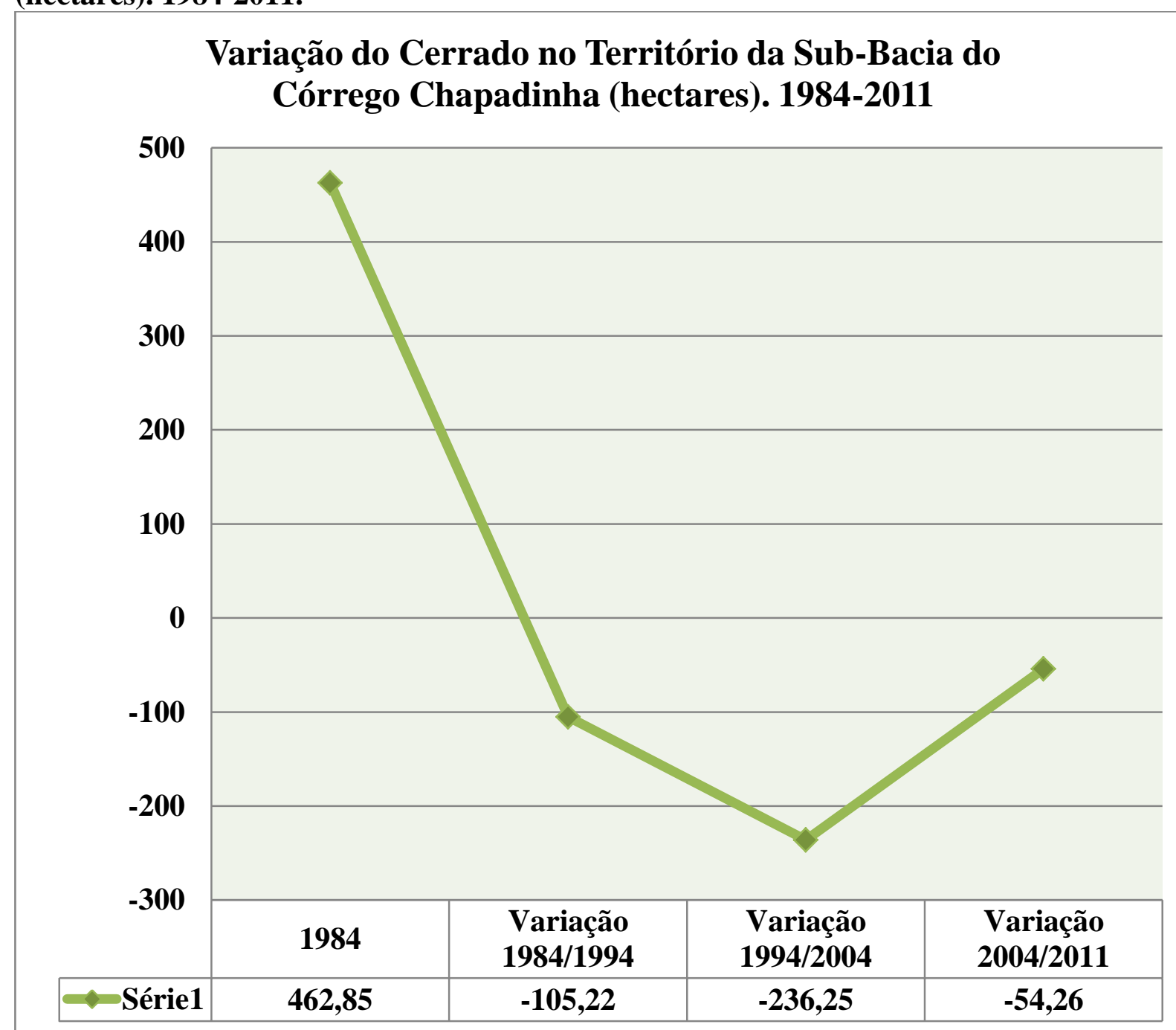




\subsubsection{CAMPO LIMPO}

A classe de campo limpo concentra-se, atualmente, próximo a cabeceira do córrego Pulador. O mapeamento esclareceu que, em 1984, a extensão de campo limpo era de 108,98 hectares, com valor em porcentagem de 4,66\%; em 1994, representava 75,54 hectares, equivalendo-se a 3,23\%; em 2004, ocupava 52,63 hectares, representando 2,25\%; e, em 2011, foi reduzida para 45,15 hectares, correspondendo a 1,93\% da área total do território da Subbacia do Córrego Chapadinha (Tabela 02). A variação dessa classe é ilustrada no Gráfico 07, entre 1984 e 1994 foi de 33,44 hectares para menos; entre 1994 e 2004, reduziu-se para 22,91 hectares; e, em 2011, foi constatada uma redução de 7,47 hectares. A variação para menos em 1994, 2004 e 2011 decorre do avanço das áreas agrícolas do Assentamento Bela Vista.

Gráfico 07 - Variação do Campo Limpo no Território da Sub-Bacia do Córrego Chapadinha (hectares). 1984-2011.

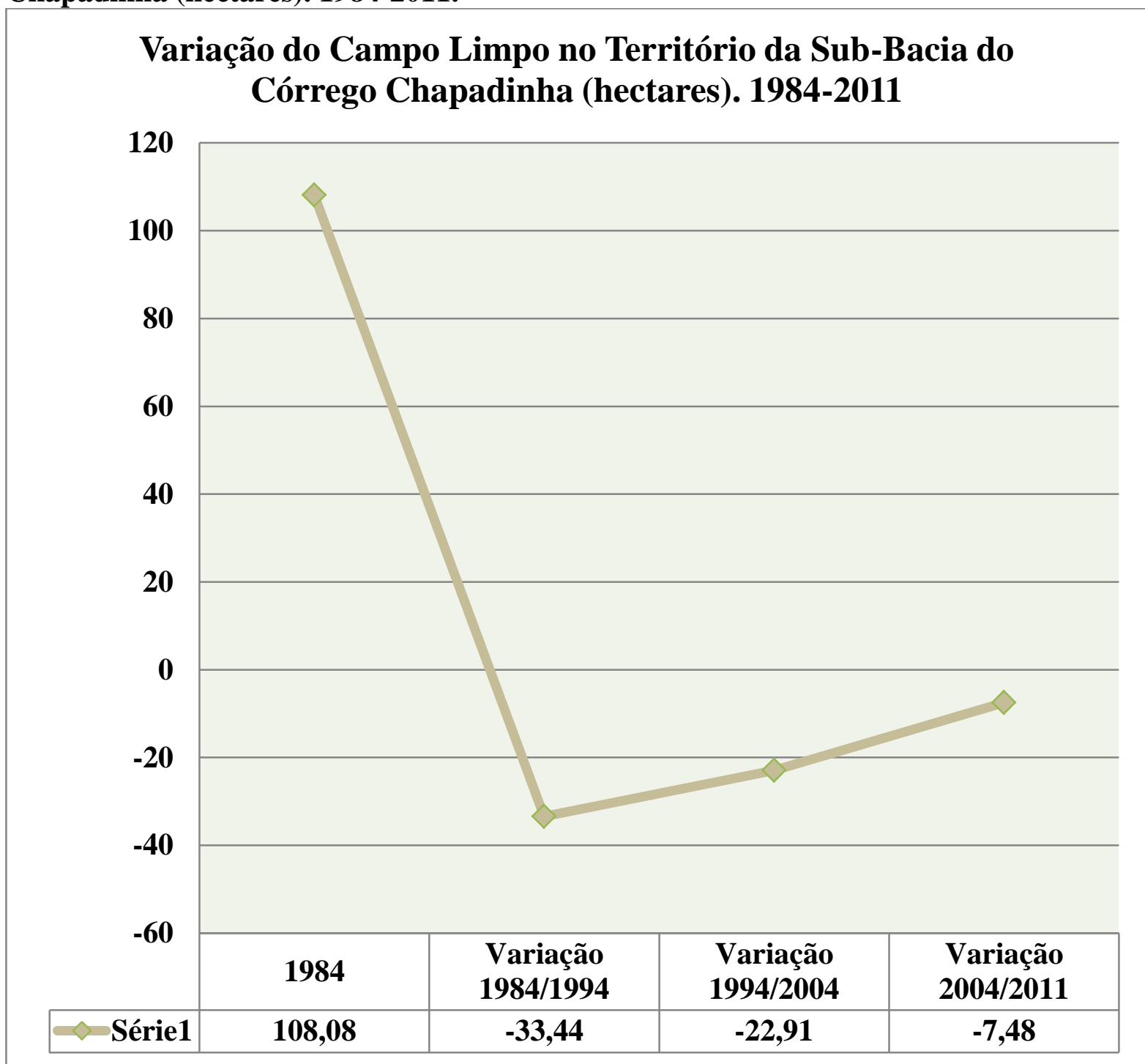




\subsubsection{CULTURA}

Pela análise realizada na Tabela 02, no período entre 1984 e 2004, observa-se um crescimento bastante expressivo na classe de cultura. Em 1984, representava 113,45 hectares (4,85\%); em 1994, 192,72 hectares (8,24\%); em 2004, 1003,83 (42,92\%); e, em 2011, 938,82 hectares $(40,14 \%)$ da área total do território da Sub-bacia. O crescimento da classe cultura está associado à diminuição do Cerrado e da pastagem. O Cerrado perdeu espaço, principalmente nas proximidades da nascente do córrego Pulador. A pastagem cedeu espaço nas áreas que eram de reflorestamento e nessa localidade se encontram os Assentamentos Maranata e Bela Vista. Quanto à variação (Gráfico 08), entre 1994 e 2004, houve maior oscilação: o acréscimo foi de 811,11 hectares, enquanto que, no período de 2004 a 2011, a variação foi de 65,01 hectares para menos. Tal fato está associado ao aumento da Mata de Galeria, próxima ao lago Descoberto.

Gráfico 08 - Variação da Cultura no Território da Sub-Bacia do Córrego Chapadinha (hectares). 1984-2011.

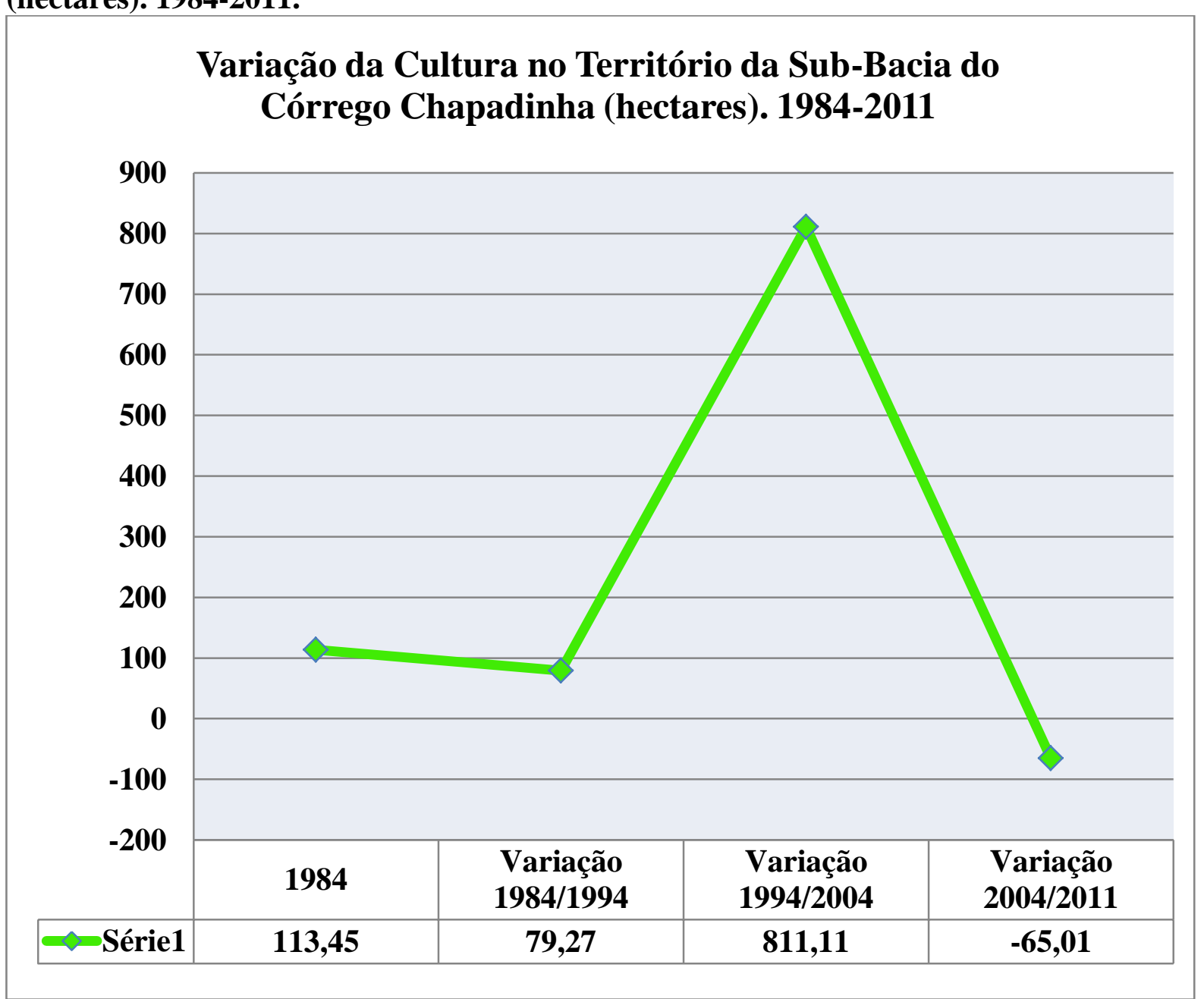




\subsubsection{LAGOS}

Conforme observado na Tabela 02, das classes mapeadas, a área dos lagos foi a que teve a menor alteração. Nota-se que essa classe se manteve praticamente estável. Em 1984, representava $1,08 \%$, equivalente a 25,26 hectares; em 1994, ocupava $1,13 \%$, equivalente a 26,42 hectares; em 2004, era de 1,04\% ou 24,33 hectares; e, em 2011, abrangia 1,02\% representando 23,85 hectares da área total do território da Sub-bacia do Córrego Chapadinha. Quanto à variação, no período entre 1984 e 1994, houve acréscimo de 1,16 hectares; nos períodos de 1994 a 2004 e 2004 a 2011, diminuíram 2,09 hectares e 0,48 hectares, respectivamente (Gráfico 09). Observa-se que a legenda propõe apenas lagos artificiais. Nessa categoria, foram identificados dois: o lago Descoberto e o lago Veredinha, ambos artificiais. Vale lembrar que as suas fundações antecedem o ano de 1984. Esta pequena variação é em decorrência da ocupação rural da APA da Bacia do Rio Descoberto e da intensificação da cultura nessa APA, que provocou o carreamento de sedimentos ao leito do lago Descoberto e como consequência alterou a capacidade em termos de volume. Dessa forma, os meses de junho, julho e agosto, em que foram coletadas as imagens utilizadas para análise, coincidem com o período de seca no DF. Nessas datas, uma parte do leito do lago Descoberto fica exposto, provocando assim, a variação observada.

Gráfico 09 - Variação dos Lagos no Território da Sub-Bacia do Córrego Chapadinha (hectares). 1984-2011.

\section{Variação dos Lagos no Território da Sub-Bacia do Córrego Chapadinha (hectares). 1984-2011}

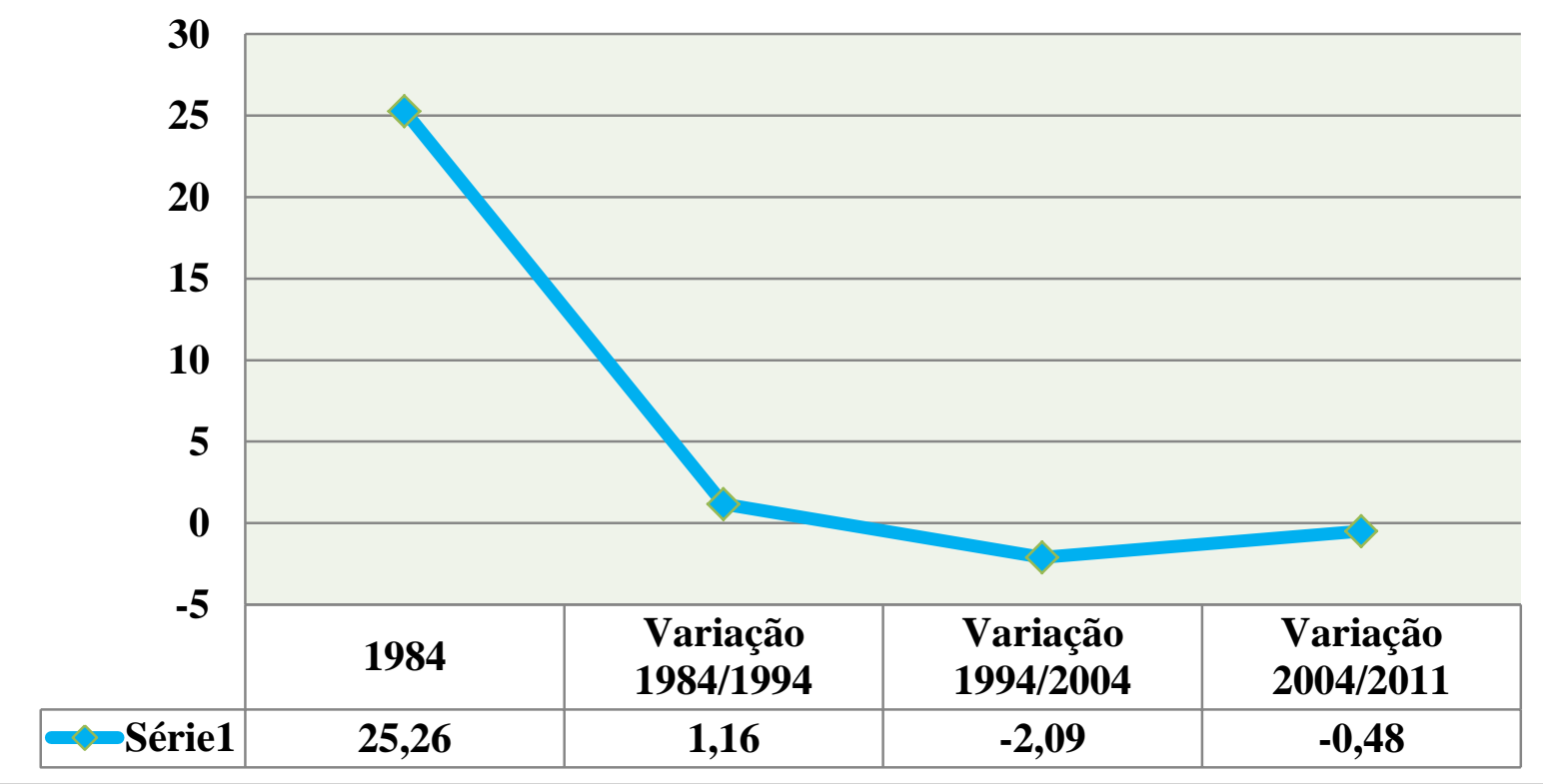




\subsection{CARACTERIZAÇÃO DOS ATORES E DE SEUS INTERESSES.}

Com base na pesquisa de campo foram identificados vários atores, alguns se fazem presentes nos conflitos e outros fizeram parte. Entretanto, todos são importantes para a análise, a ver:

1) Parque Ecológico Veredinha: moradores, Instituto Brasília Ambiental (IBRAM) e MPDFT;

2) Assentamento Maranata e setor Capãozinho: Associação dos Produtores Rurais do Projeto Maranata, Associação dos Pequenos Produtores Rurais do Capãozinho, moradores, político, Instituto Chico Mendes de Conservação da Biodiversidade (ICMBio), MPDFT e mediador;

3) Assentamento Bela Vista: Associação dos Produtores Rurais do Assentamento Bela Vista, moradores, político e Agência de Desenvolvimento do Distrito Federal (TERRACAP);

4) Novo Assentamento, quadras 33 e 34 e lotes nos antigos becos: Cooperativa Habitacional dos Servidores de Segurança Pública de Brazlândia, moradores e Companhia de Desenvolvimento Habitacional do Distrito Federal (CODHAB).

\section{I - PARQUE ECOLÓGICO VEREDINHA}

\section{Moradores}

Esses atores são fiscalizados constantemente pelo órgão ambiental (IBRAM). Alguns residem há mais de cinquenta anos no parque e possuem termo de doação do imóvel registrado em cartório.

Interesse: regularização fundiária com a permanência no parque e conservação ambiental.

\section{Instituicões Públicas}

1) IBRAM

O IBRAM foi criado por meio da Lei $\mathrm{n}^{\circ} 3.984 / 2007$, para ser o órgão executor de políticas públicas ambientais e de recursos hídricos do DF. Foi constituído como uma autarquia vinculada à Secretaria de Estado de Desenvolvimento Urbano e Meio Ambiente do DF.

Interesse: desapropriação dos imóveis e conservação ambiental.

2) MPDFT

O Art. 127 da Carta Magna de 1988 reza que ao MP incumbe a defesa da ordem jurídica, do regime democrático e dos interesses sociais e individuais indisponíveis. Entre as 
funções do MPDFT, destacam-se os itens I e III do Art. 129 da CF de 1988, que é promover a ação penal pública, o inquérito civil e a ação civil pública, para a proteção do patrimônio público e social, do meio ambiente e de outros interesses difusos e coletivos. $\mathrm{O}$ órgão evoca o princípio da legalidade na defesa ambiental.

Interesse: aplicação das normas com desapropriação dos imóveis.

\section{II - ASSENTAMENTO MARANATA E SETOR CAPÃOZINHO}

\section{$\underline{\text { Associacões }}$}

São representações informais do Assentamento Maranata e do setor Capãozinho, não são reconhecidas legalmente. Porém, exercem influência, principalmente, no meio político, promovendo reuniões e eventos para discutir a regularização dos assentamentos.

1) Associação dos Produtores Rurais do Projeto Maranata

Como o assentamento não tem a regularização fundiária, a associação também não é reconhecida legalmente. Dessa forma, não há como angariar infraestrutura e nem recursos como equipamentos, adubos, rações e financiamentos.

Interesse: regularização fundiária com permanência dos moradores e conservação ambiental.

2) Associação dos Pequenos Produtores Rurais do Capãozinho

De acordo com o presidente da associação, a formação da Floresta Nacional de Brasília não se preocupou com os antigos moradores, alguns com mais de setenta anos de residência e com as propriedades escrituradas.

Interesse: regularização fundiária com permanência dos moradores e conservação ambiental.

\section{Moradores}

Estes são representados pelas associações, participam com assiduidade dos eventos políticos e das reuniões. Apesar de serem moradores antes mesmo da criação da Floresta Nacional de Brasília, estão proibidos de construir qualquer tipo de edificação e são constantemente fiscalizados pelo ICMBio. Aqueles que desrespeitam são multados e têm as obras embargadas ou demolidas. Uma das poucas atividades desenvolvidas por eles é o cultivo de hortifrúti tanto para subsistência quanto para o comércio.

Interesse: regularização fundiária com permanência dos moradores e conservação ambiental. 


\section{Político}

Senador do DF, que no dia 17 de março de 2014, presidiu uma audiência pública no Senado Federal para debater os problemas relacionados a Floresta Nacional de Brasília. Interesse: buscar uma solução consensual que atenda a conservação dos recursos hídricos e atenue o conflito; e projeção política.

\section{Instituicões Públicas}

1) ICMBio

O ICMBio é uma autarquia em regime especial, criado por meio da Lei $\mathrm{n}^{\circ}$ 11.516/2007. O instituto é vinculado ao Ministério do Meio Ambiente (MMA) e integra o Sistema Nacional do Meio Ambiente e cabe a ele executar as ações do SNUC, podendo propor, implantar, gerir, proteger e monitorar as unidades de conservação instituídas pela União.

Interesse: desapropriação dos imóveis, transferência da área passando o domínio da TERRACAP para a União e elaboração do Plano de Manejo.

\section{2) MPDFT}

O Ministério Público busca a legalidade dos fatos com aplicação da lei.

Interesse: desapropriação dos imóveis, transferência da área passando o domínio da TERRACAP para a União e elaboração do Plano de Manejo.

\section{Mediador}

Ambientalista

O mediador tenta buscar uma alternativa que concilie moradia com conservação. De acordo com o Ambientalista, o Assentamento Maranata foi construído num remanescente de pinus, cuja área já não exerce o papel para o qual foi criado: da conservação. Destaca-se, ainda, que a área do Capãozinho tem ocupações com mais de setenta anos, com vínculos culturais e títulos de posse.

Interesse: regularização fundiária com permanência dos moradores e participação deles na conservação do meio ambiente, por meio de plantios com técnicas não nocivas; e reconfiguração da área da Floresta Nacional de Brasília. 


\section{III - ASSENTAMENTO BELA VISTA}

\section{$\underline{\text { Associação }}$}

Associação dos Produtores Rurais do Assentamento Bela Vista. Representa os moradores, foi decisiva na formação e efetivação do assentamento, em 1996, inclusive contratando advogados para intermediar a permanência junto a TERRACAP. Atualmente, a associação busca melhorias, principalmente na parte de infraestrutura.

Interesse: regularização fundiária por meio das escrituras dos imóveis.

\section{Moradores}

São os atores principais do conflito e visam à solução do embate, cujo ponto principal está no Contrato de Concessão de Uso Oneroso de Imóvel Rural com a TERRACAP. Alguns enxergam o contrato com ceticismo.

Interesse: regularização fundiária por meio das escrituras dos imóveis.

\section{Político}

Deputado Distrital que exerceu o mandato no período de 1995 a 1998, à época era um político influente com participação no GDF. O político articulou a instalação de energia elétrica junto a Companhia Energética de Brasília (CEB) e promoveu outras ações, porém na entrevista não comentou sobre essas ações. Nos pleitos posteriores a seu mandato não conseguiu se reeleger.

Interesse: projeção política.

\section{Instituicão Pública}

TERRACAP

A TERRACAP foi criada por meio da Lei $\mathrm{n}^{\circ} 5.861 / 1972$, é uma empresa pública do GDF. A partir de 1997, passou a exercer a função de Agência de Desenvolvimento do DF na operacionalização e implementação de programas e projetos com promoção, direta ou indireta, de investimentos em parcelamentos do solo, infraestrutura e edificações. A Companhia administra as áreas onde está localizado o Assentamento Bela Vista. O órgão tenta firmar com os moradores o Contrato de Concessão de Uso Oneroso de Imóvel Rural. Interesse: firmar o contrato com os moradores para manter o controle sobre as terras. 


\section{IV - ÁREA URBANA (NOVO ASSENTAMENTO, OS LOTES DOS ANTIGOS BECOS E AS QUADRAS 33 E 34 DA VILA SÃO JOSÉ)}

\section{Cooperativa}

Cooperativa Habitacional dos Servidores de Segurança Pública de Brazlândia

A cooperativa representa os moradores das residências construídas nos antigos lotes oriundos de becos. De acordo com o presidente da cooperativa, a aquisição de locais para moradia por meio de programas do GDF era uma reivindicação dos servidores de segurança pública de Brazlândia. A solução foi a ocupação legal dos becos, em 1998, que eram usados por usuários de drogas ou pela população como depósitos de lixos.

Interesse: regularização fundiária com entrega das escrituras.

\section{Moradores}

São os atores principais do conflito, exercem papel discreto no conflito. No momento estão aguardando um posicionamento da CODHAB.

Interesse: regularização fundiária com entrega das escrituras.

\section{Instituicão Pública}

CODHAB

A CODHAB foi criada por intermédio da Lei $n^{\circ} 4.020 / 2007$ e tem por finalidade a execução da política de desenvolvimento habitacional do DF, podendo articular-se com políticas e programas que visem ao desenvolvimento das funções econômicas e sociais da população, preferencialmente a de baixa renda, com o intento de assegurar o bem-estar das comunidades, a melhoria da qualidade de vida e a preservação do meio ambiente. Atualmente, é vinculada à Secretaria de Estado de Habitação, Regularização e Desenvolvimento Urbano.

Em 2013, a CODHAB cadastrou os moradores do Novo Assentamento e das quadras 33 e 34, visando à regularização por meio da entrega das escrituras dos imóveis. Para os lotes nos antigos becos, a CODHAB realizou, no mês de janeiro de 2014, duas Audiências Públicas, momento em que foi discutida a regularização das áreas com proposta de formulação de Projeto de Lei Complementar para ser encaminhada a Câmara Legislativa do DF para aprovação.

Interesse: regularização fundiária com entrega das escrituras. 
Com base na caracterização dos atores acima detalhada, foi desenvolvido a matriz síntese de todos os conflitos, conforme quadro abaixo:

Quadro 07 - Matriz Síntese de Caracterização dos Atores dos Principais Conflitos Socioambientais Identificados.

\begin{tabular}{|c|c|}
\hline \multicolumn{2}{|r|}{ Parque Ecológico Veredinha } \\
\hline Atores & Interesse \\
\hline Moradores & $\begin{array}{l}\text { - Regularização fundiária e com a permanência no parque; } \\
\text { - } \quad \text { Conservação ambiental. }\end{array}$ \\
\hline IBRAM & $\begin{array}{l}\text { - Desapropriação dos imóveis; } \\
\text { - Conservação ambiental. }\end{array}$ \\
\hline MPDFT & - Aplicação das normas com desapropriação dos imóveis. \\
\hline \multicolumn{2}{|r|}{ Assentamento Maranata e Setor Capãozinho } \\
\hline Atores & Interesse \\
\hline Associações & $\begin{array}{l}\text { - Regularização fundiária com permanência dos moradores; } \\
\text { - } \quad \text { Conservação ambiental. }\end{array}$ \\
\hline Moradores & $\begin{array}{l}\text { - Regularização fundiária com permanência dos moradores; } \\
\text { - } \quad \text { Conservação ambiental. }\end{array}$ \\
\hline $\begin{array}{l}\text { Político } \\
\text { (Senador) }\end{array}$ & $\begin{array}{l}\text { - Busca de uma solução consensual que atenda a conservação } \\
\text { dos recursos hídricos e atenue o conflito; } \\
\text { - Projeção política. }\end{array}$ \\
\hline ICMBio & $\begin{array}{l}\text { - } \quad \text { Desapropriação dos imóveis; } \\
\text { - Transferência de domínio da TERRACAP à União; } \\
\text { - Elaboração do Plano de Manejo. }\end{array}$ \\
\hline MPDFT & $\begin{array}{l}\text { - } \quad \text { Desapropriação; } \\
\text { - Transferência de domínio da TERRACAP à União; } \\
\text { - Elaboração do Plano de Manejo. }\end{array}$ \\
\hline $\begin{array}{l}\text { Mediador } \\
\text { (Ambientalista) }\end{array}$ & $\begin{array}{l}\text { - Regularização fundiária com permanência dos moradores e } \\
\text { participação dos mesmos na conservação do meio ambiente, } \\
\text { por meio de plantios com técnicas não nocivas; } \\
\text { - Reconfiguração da área da Floresta Nacional de Brasília. }\end{array}$ \\
\hline \multicolumn{2}{|r|}{ Assentamento Bela Vista } \\
\hline Atores & Interesse \\
\hline Associação & - Regularização fundiária por meio das escrituras dos imóveis. \\
\hline Moradores & - Regularização fundiária por meio das escrituras dos imóveis. \\
\hline Político & - Projeção política. \\
\hline TERRACAP & $\begin{array}{l}\text { - Firmação de contrato com os moradores para manter o controle } \\
\text { sobre as terras. }\end{array}$ \\
\hline \multicolumn{2}{|c|}{ Novo Assentamento, Quadras 33 e 34 e Lotes nos Antigos Becos } \\
\hline Atores & Interesse \\
\hline Cooperativa & - Regularização fundiária com entrega das escrituras. \\
\hline Moradores & - Regularização fundiária com entrega das escrituras. \\
\hline CODHAB & - Regularização fundiária com entrega das escrituras. \\
\hline
\end{tabular}




\subsection{ESTRUTURAÇÃO DOS CONFLITOS}

Diante das considerações efetuadas até o momento, constata-se que o território da Sub-bacia do Córrego Chapadinha não se configura como palco de um único conflito. Nesse contexto, nos tópicos que se seguem, é apresentada uma descrição dos principais momentos da estruturação dos conflitos, respeitando a seguinte ordem: Parque Ecológico Veredinha, Assentamento Maranata e setor Capãozinho, Assentamento Bela Vista e por fim o Novo Assentamento, quadras 33 e 34 e os lotes nos antigos becos.

\subsubsection{PARQUE ECOLÓGICO VEREDINHA}

Conforme o Plano de Manejo elaborado, em 2006, pela empresa Geo Lógica Consultoria Ambiental, a proposta de criação do parque teria iniciado a partir de uma solicitação da Divisão Regional de Ensino de Brazlândia. Sugeriu-se um bosque, para assegurar a proteção da principal área verde natural situada no interior da cidade. No Decreto de criação, são consideradas três justificativas básicas, de forma resumida: 1) a preservação da bacia do córrego Veredinha, que é um contribuinte do sistema de abastecimento do lago Descoberto; 2) a importância da presença dentro da paisagem urbana de um curso com suas nascentes e vegetação típica do Cerrado; e 3) o interesse em se prover a comunidade de áreas que favoreçam o esporte, a cultura e o lazer em contato direto com o meio natural. Conforme descrito no tópico 3.2 desta dissertação, a criação foi autorizada em 1992 e concretizada em 1994.

Nesse contexto, a lei $\mathrm{n}^{\mathbf{o}}$ 302/1992 pode ser considerada o marco inicial do conflito no Parque Ecológico Veredinha, pois a desapropriação dos imóveis era uma das recomendações elencadas em seu texto. Contudo o conflito foi ratificado com a criação do parque, que ocorreu por intermédio do Decreto ${ }^{\circ}$ 16.052/1994, documento que confirmou a desocupação da unidade. A partir de então, uma série de acontecimentos vem endossando a concretização do parque, com ausência total de habitantes.

O primeiro ocorreu em 1999, com a sanção da Lei Complementar no 265, que dispõe sobre a criação dos Parques Ecológicos e de Uso Múltiplo no DF. O Art. 22 proibiu o uso residencial, permanente ou temporário, no interior dos Parques Ecológicos. Mas, o $\S 2^{\circ}$ do mesmo art. reza que as ocupações existentes até a data de criação dos parques, serão objeto de lei específica. De acordo com Ganem e Leal (2002), há uma incongruência entre o caput e o § 
$2^{\circ}$, enquanto o primeiro proíbe, o segundo permite as ocupações já existentes. Segundo as autoras, o problema foi decorrente do pouco tempo disponível para negociação entre os representantes do poder executivo e os deputados distritais, pois a matéria foi votada em regime de urgência.

Em 2007, o GDF expediu um novo documento que rezava acerca do parque, por meio do Decreto $\mathrm{n}^{\circ} 28.620$ declarou-se que era de utilidade pública, para fins de desapropriação, a área situada no imóvel Chapadinha, destinada à preservação ambiental. O Decreto, em seu Art. $1^{\circ}$, deixou bem claro a desapropriação do parque. Já em seu Art. $3^{\circ}$ declarou que era de responsabilidade da TERRACAP a indenização pela desapropriação. Não Obstante o GDF expediu, em 2009, o Decreto $\mathrm{n}^{\circ} 30.044$, anulando o Decreto ${ }^{\circ}$ 28.620/2007.

Em 2010, o GDF sancionou a Lei Complementar $n^{\circ}$ 827, instituindo o Sistema Distrital de Unidade de Conservação, que estabelece, atualmente, os critérios e normas para criação, implantação, alteração e gestão das unidades de conservação no território do DF. Nesse sentido, o $\S 1^{\circ}$ do Art. 18 descreve que "O Parque Ecológico é de posse e domínio públicos, sendo que as áreas particulares incluídas em seus limites serão desapropriadas, de acordo com o que dispõe a lei”. Assim, o SDUC reforçou de vez todos os documentos legais anteriores, que determinavam a desapropriação dos imóveis na área do parque.

Por oportuno, é importante frisar que, desde a criação do parque, vários problemas foram apontados pelo MPDFT, os quais se tornaram objetos de processo junto ao Tribunal de Justiça do Distrito Federal e Territórios, como a real implantação do parque, a ineficiência da gestão por parte do órgão competente e a não desapropriação dos imóveis, fatores que têm levado à degradação do parque.

Nesse sentido, em 2010, o MPDFT ingressou com uma ação civil pública contra o GDF, o IBRAM e a TERRACAP. De acordo o MPDFT, desde a criação, até o mês de novembro de 2010, o parque não havia sido efetivamente implantado. Por consequência, os recursos naturais têm sido objeto de contínua degradação, principalmente as nascentes do córrego Veredinha.

No processo, pesaram contra o GDF as ações e as omissões que retardam a implantação do parque; contra o IBRAM, a omissão de gestão, de conservação e de fiscalização. Em desfavor da TERRACAP pesou a omissão que concorreu para a degradação da área, na medida em que a instituição não promoveu a desapropriação das terras privadas integradas ao parque. Salienta-se que, na ação, o MPDFT requereu ainda a anulação definitiva do Decreto n 30.044/2009, a condenação dos réus à obrigação de se fazer consistente em 
cada esfera de atribuição. Em 2010, através da NOVACAP, o GDF cercou com telas todo o perímetro do parque, porém a TERRACAP não removeu os habitantes. Com relação ao trabalho do IBRAM, também, em 2010, o instituto inaugurou as instalações da sede na área do parque.

Durante a elaboração do Plano de Manejo, a empresa Geo Lógica Consultoria Ambiental realizou uma pesquisa de campo para fazer o levantamento da real situação fundiária. $\mathrm{Na}$ ocasião, ficou constatado que a situação fundiária configura-se a partir da distinção entre dois grupos diferenciados: moradores mais recentes estabelecidos nos últimos quinze anos; e moradores mais antigos, que residem há mais de vinte anos. Os habitantes são distribuídos em 21 áreas denominadas chácaras, as quais contam com 56 edificações e 216 ocupantes.

No Quadro 08, os resultados dos levantamentos de campo estão organizados por setores, seguindo o endereçamento adotado pelos ocupantes. Em seguida, os casos foram ordenados por tempo de ocupação. A tabela revela que, aproximadamente, $62 \%$ das ocupações estão a mais de vinte anos no local.

Quadro 08 - Moradores do Parque, Organizados Segundo os Locais e Tempo de Ocupação.

\begin{tabular}{l|l|l|l}
\hline Endereço & Tempo no local & Estado de nascimento & Tempo no DF \\
\hline AE 5 ch 4 & 02 anos & GO & 30 anos \\
\hline AE 5 Qd 1 casa 1 ch 1 & 03 anos & MG & 20 anos \\
\hline AE 5 ch 5 S. Veredas & 09 anos & MG & 34 anos \\
\hline AE 5 ch 5 S. Veredas & 12 anos & MG & 28 anos \\
\hline AE 5 ch 3 & 13 anos & PE & 35 anos \\
\hline AE 5 ch 3 & 20 anos & DF & 20 anos \\
\hline AE 5 ch 4 S.Veredas & 48 anos & GO & 60 anos \\
\hline Qd 10 ch 9 S. Norte & 08 anos & GO & 09 anos \\
\hline Qd 10 ch 12 S. Norte & 10 anos & BA & 34 anos \\
\hline Qd 10 ch 11 S. Norte & 35 anos & MG & 35 anos \\
\hline Qd 10 ch 9 S. Norte & 35 anos & DF & 35 anos \\
\hline Qd 10 ch 11 S. Norte & 35 anos & MG & 35 anos \\
\hline Qd 10 ch 9 S. Norte & 37 anos & MG & 37 anos \\
\hline Qd 5 ch 1 casa 1 S. Norte & 01 ano & SP & 30 anos \\
\hline Qd 5 ch 3 S. Norte & 21 anos & DF & 21 anos \\
\hline Qd 5 ch 3 S. Norte & 27 anos & DF & 27 anos \\
\hline Qd 5 ch 3 S. Norte & 30 anos & DF & 30 anos \\
\hline Ch 13 S. Veredas & 36 anos & GO & 37 anos \\
\hline Qd 1 ch 3 Norte & 37 anos & GO & 53 anos \\
\hline AE 2 ch 2 Qd 5 S. Norte & 40 anos & GO & 47 anos \\
\hline Ch da Proteção 12 S. Norte & 47 anos & GO &
\end{tabular}

Fonte: Plano de Manejo do Parque Ecológico Veredinha, desenvolvido pela empresa Geo Lógica, em 2006. 
Ganem e Leal (2002), com a pesquisa intitulada "Parques do Distrito Federal: desafios à sua implantação", colaboram no entendimento da estruturação do conflito socioambiental no Parque Ecológico Veredinha. Na pesquisa, são relatados os principais problemas relacionados à criação dos parques no DF, sobretudo no que diz respeito à sua organização. De acordo com as autoras, a expansão de áreas de parques no DF ocorreu de forma acelerada e desordenada, sem nenhum estudo prévio. Não havia, até 1999, nenhuma norma legal estabelecendo os objetivos e características dos parques e critérios para sua criação e implantação. O aumento do número de parques ocorreu na década de 1990. Isso, em parte, reflete o envolvimento do Poder Legislativo do DF, surgido em 1991, nesse processo, sobretudo entre 1995 e 1998, que coincide com a segunda legislatura da Câmara Legislativa do DF. Nesse período, dos 23 parques existentes, vinte foram criados por meio de lei e apenas três, por decreto.

O principal problema encontrado pelas pesquisadoras foram as ocupações humanas, principalmente aquelas para fins de moradias. Elas esclarecem que é uma situação comum em muitos parques. Muitas vezes, as leis e os decretos de criação são omissos quanto a esta questão. Quando as leis e os decretos preveem a desocupação, o poder executivo torna-se omisso, não cumprindo a desapropriação ou a desocupação do espaço conservado pelas leis e decretos.

A solução proposta pelas autoras para a questão seria a realocação dos moradores mais recentes em lotes regularizados na área urbana. Aos moradores mais antigos seria garantido o direito de permanência, respeitando os vínculos firmados com o lugar. Assim, o direito de permanência poderia ser um contrato de concessão de uso de área pública, com estabelecimento de condições que garantissem o não desenvolvimento de atividades prejudiciais à conservação da área dos parques e ao seu uso como área de lazer, pela população local. Agregado a solução das autoras, seria viável uma intensificação na fiscalização pelo órgão gestor para averiguação do fiel cumprimento do contrato de concessão de uso. Observa-se que a pesquisa de Ganem e Leal é de 2002, porém ela reflete bem a situação atual do Parque Ecológico Veredinha: já são 21 anos de constantes embates.

A análise do mapa de uso do território elaborado pelo IBRAM, em 2013, revela claramente a quantidade em hectares das áreas antropizadas no parque. As áreas ocupadas por residências equivalem a 3,39 hectares, a agricultura em forma de hortas comunitárias ocupam 2,19 hectares, as outras áreas antropizadas somam juntas 8,15 hectares (Figura 14). 
Figura 14 - Mapa de Uso do Território do Parque Ecológico Veredinha.

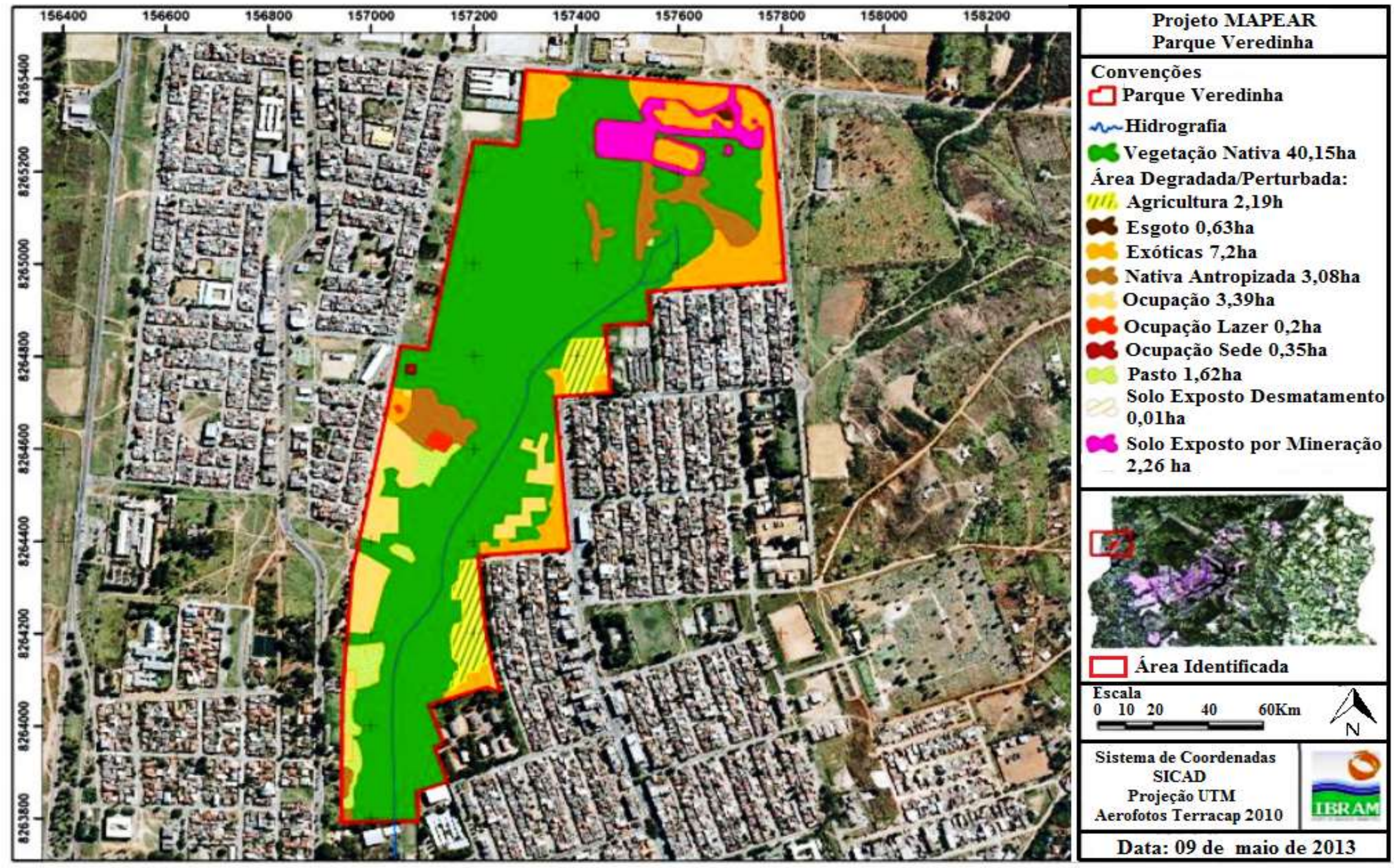

Fonte: Projeto Mapear do IBRAM.

Nota: Entre as classes propostas pelo IBRAM está o solo exposto por mineração. Constata-se um equívoco na definição da legenda, uma vez que o solo exposto está relacionado à construção das bacias de contenção de águas pluviais. 
O que se observou nesse caso é a luta entre uma comunidade que busca o direito de permanência - moradia - e o órgão gestor com a conservação do meio ambiente, com desapropriação total dos imóveis. Nesse sentido, o conflito é de natureza social, ambiental e legal: Primeiro, é social porque busca garantir o direito social à moradia, com pleno desenvolvimento das funções sociais; segundo, é ambiental, porque visa ao uso sustentável da natureza de forma a cumprir as justificativas e os objetivos previstos no Decreto de criação como preservação dos recursos hídricos, promoção da educação ambiental a partir da comunidade e do seu contato direto com o meio natural; e terceiro, é legal, pois visa ao cumprimento do Decreto de criação do parque (Decreto $\left.\mathrm{n}^{\circ} 16.052 / 1994\right)$ e os demais documentos pertinentes a desapropriação, principalmente, o $§ 1$ do Art. 18 do SDUC.

Nesse contexto, cabem algumas considerações. No que tange à natureza social, a pesquisa de campo revelou que as ocupações são constituídas por chácaras, com construções de alvenarias, contam com energia e água potável fornecidas pela CEB e CAESB, respectivamente. Observa-se que essas chácaras não são oriundas de invasões e se integram de forma mais harmoniosa com o meio natural circundante, com plantações de árvores frutíferas e ornamentais.

Há de se reforçar que, nas entrevistas, constatou-se a existência de moradores com mais de cinquenta anos de fixação na área do parque, inclusive com termos de escrituras e/ou termos de doações registrados em cartório. Salienta-se que esses moradores possuem vínculos simbólicos e culturais com o local, pois algumas chácaras foram herdadas de seus antecedentes. Dessa forma, remonta a existência de vida de seus habitantes. Nesse sentido, a transferência dos moradores romperá os vínculos firmados, podendo ter profundo efeito negativo sobre os eles, pois as novas moradias, certamente, não reproduzirão as condições antes vividas.

Quanto ao fator ambiental, é salutar reconhecer a importância de áreas verdes no interior da cidade de Brazlândia, principalmente para resguardar o direito da população local a um meio ambiente saudável com áreas que favoreçam a cultura, a educação ambiental e o lazer em contato direto com o meio natural. O ponto fundamental da conservação é a garantia da qualidade dos recursos hídricos, já que as águas do córrego Veredinha abastecem o lago Descoberto. Este, por sua vez, fornece água potável para várias regiões no DF. No entanto, a política de cercamento do parque e de exclusão dos atuais moradores pode contribuir para o agravamento da degradação ambiental, pois os moradores têm contribuído para a sua conservação, impedindo a ação de atividades impactantes como o desmatamento e o despejo 
de lixo e entulhos. Tais ações, se realizadas, podem causar prejuízos irreversíveis à bacia do córrego Veredinha. Assim, a retirada deles, ao invés de constituir medida de proteção ao parque, poderá torná-lo mais vulnerável, já que o órgão gestor não tem condições efetiva de fiscalização. Na atualidade, o IBRAM conta com dois funcionários e um veículo oficial para as diversas atividades. De acordo com o Técnico de Atividade de Meio Ambiente, representante local do IBRAM, os recursos disponíveis não são suficientes para uma boa gestão, devido à extensão e à localização do parque, no interior da área urbana de Brazlândia.

Destarte, o conflito socioambiental em questão, atualmente, está de certa forma "adormecido", no momento as ações do órgão se reduzem a pequenas restrições, como a proibição de novas edificações ou reforma das residências já existentes. Por fim, esse caso revela simplesmente o descaso das autoridades, principalmente, do governo local, que ignora os fatos e não toma uma decisão em favor de uma parte ou da outra.

\subsubsection{ASSENTAMENTO MARANATA E SETOR CAPÃOZINHO}

Conforme apresentado anteriormente no tópico 3.2 desta dissertação, em 1996, a área situada na porção sudoeste do território da Sub-bacia do Córrego Chapadinha, foi invadida. Tal ato gerou o Assentamento Maranata. Observa-se, também, que, próximo ao Assentamento Maranata está o Córrego Capãozinho e às margens de suas Matas de Galeria situa-se o setor Capãozinho (Figura 15).

Figura 15 - Localização do Assentamento Maranata e do Setor Capãozinho.

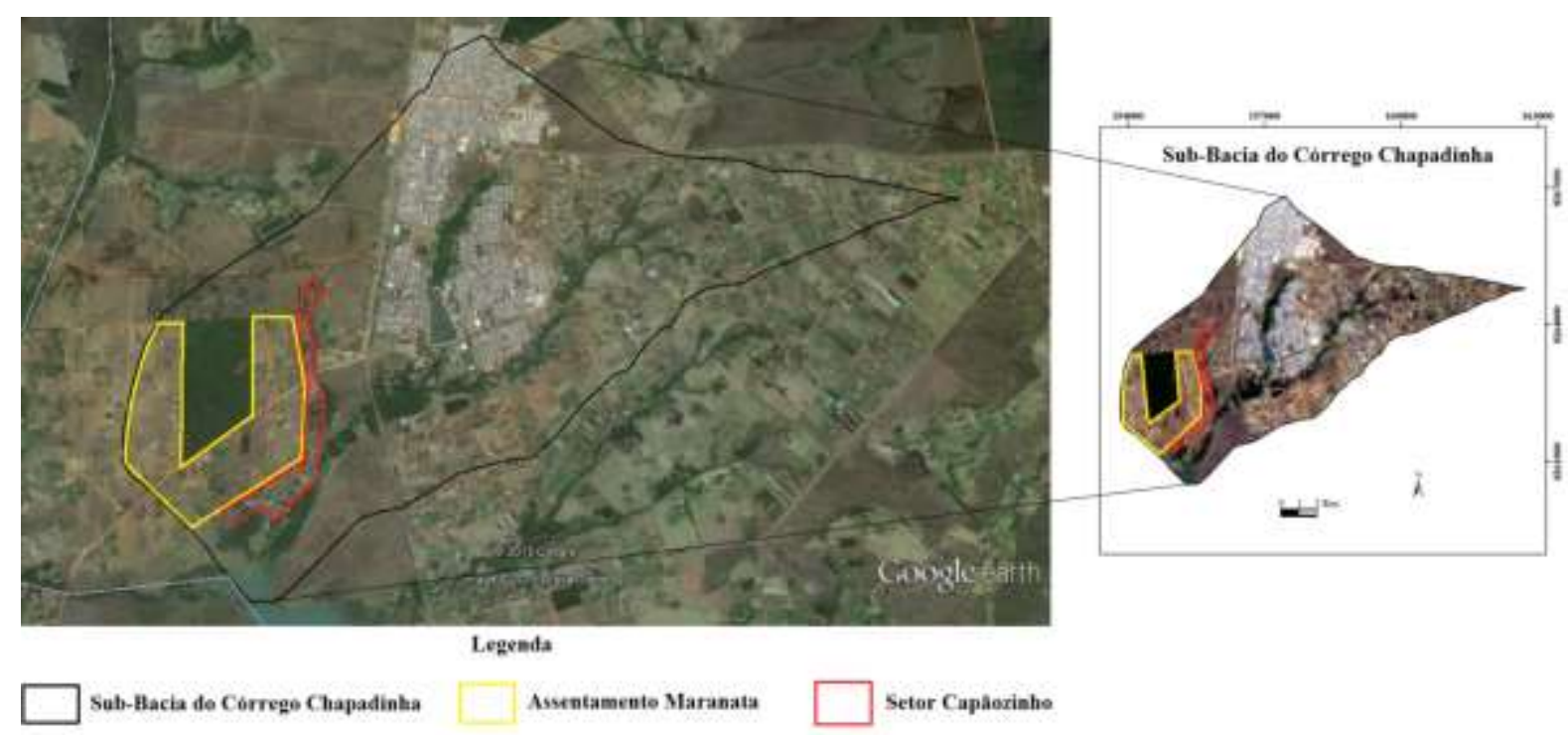

Imagem: Google Earth, 2014.

Elaboração: Gilney de Araújo Costa (Programa de Pós-Graduação em Geografia, 2014). 
Em 1999, essas áreas foram englobadas pela Floresta Nacional de Brasília, que exigiu a desapropriação dos imóveis particulares existentes nela.

De acordo com o Art. 17 do SNUC:

“A Floresta Nacional é uma área com cobertura florestal de espécies predominantemente nativas e tem como objetivo básico o uso múltiplo sustentável dos recursos florestais e a pesquisa científica, com ênfase em métodos para exploração sustentável de florestas nativas".

O SNUC considera que as florestas nacionais são de posse e domínio público, assim as áreas particulares incluídas em seus limites devem ser desapropriadas. Contudo é permitida a permanência de populações tradicionais que habitam a área, antes de sua criação. Ressalta-se que a lei considera que as populações tradicionais contribuem para o movimento de conservação, manejo e sustentabilidade das florestas, porque não há, por parte delas, ações exploratórias; mas, sim, de sobrevivência, as quais contribuem para o equilíbrio da natureza. Cabe instruir que as desapropriações estavam amparadas inicialmente pelo Decreto Federal $n^{\circ}$ 1.298/1994, que, em seu Art. $7^{\circ}$, descreve que é de responsabilidade do IBAMA as desapropriações e as indenizações indispensáveis à regularização das florestas nacionais.

A Floresta Nacional de Brasília foi criada pelo Decreto Federal sem número de 1999. Constitui o grupo das unidades de conservação de Uso Sustentável e ocupa uma área de 9346,2 hectares no DF. A Floresta Nacional de Brasília tem uma particularidade em relação a outras unidades de conservação brasileiras, não é uma área contínua, é divida em quatro áreas, sendo duas na Região Administrativa de Taguatinga - FLONA 1 e 2 - e duas na Região Administrativa de Brazlândia - FLONA 3 e 4, conforme observado na Figura 10.

A FLONA 1 possui 3353,18 hectares, localiza-se entre o córrego Currais, BR 070 e a DF 240. No local ocorre reflorestamento com algumas variedades de pínus e eucaliptos, além de fitofisionomias de Cerrado. È a área mais conservada da unidade. A FLONA 2 tem 996,48 hectares e está localizada entre a via DF 240 e os córregos Cana do Reino, Cabeceira do Valo e Poço D'Água. A área da FLONA 3 tem 3071 hectares e está situada entre a via DF 180, em frente a Brazlândia e o rio Descoberto, por meio do qual faz limite com o Estado de Goiás. É nessa FLONA que se encontra o Assentamento Maranata e o setor Capãozinho. Já a área da FLONA 4 possui 1925,62 hectares e está situada entre as vias DF 435 e DF 415, envolvendo 
os córregos Capão da Onça e Barrocão. Representa a segunda área mais conservada da FLONA de Brasília.

O decreto de criação da Floresta Nacional de Brasília além requerer a desapropriação dos imóveis, prevê em seu Art. $1^{\circ}$, que a TERRACAP deve transferir mediante doação à União as terras da unidade. Contudo, o órgão ignorou e não as transferiu e diante do descaso, levou o MPDFT a emitir a Recomendação n ${ }^{0} 51 / 1999$, a qual adverte a TERRACAP para que realize, com absoluta urgência e prioridade, a doação à União, sem qualquer condição, dos terrenos destinados à constituição da unidade de conservação. Recomendação que até o presente ano, 2015, não fora acatada.

Durante a pesquisa, vislumbrou-se que os acontecimentos de 1999 a 2014, entre os principais atores, se concentraram em pouquíssimos encontros, geralmente de cunho político. Nesse sentido, no dia 17 de março de 2014, ocorreu o principal deles. A Comissão de Meio Ambiente, Defesa do Consumidor e Fiscalização e Controle realizou uma Audiência Pública para debater a conservação da Floresta Nacional de Brasília. A Audiência foi presidida por um Senador do DF e contou com a participação de vários convidados, entre eles um Ambientalista, representante dos moradores; o Presidente do ICMBio e um Promotor de Justiça de Defesa do Meio Ambiente do MPDFT.

$\mathrm{Na}$ abertura da Audiência, o Senador expôs a preocupação com ambos os lados constitutivos do conflito: ICMBio e moradores. Para ele a conservação ambiental é imprescindível, principalmente pela preservação dos mananciais contidos na região utilizados para consumo humano. De acordo com o político, a criação da Floresta Nacional de Brasília foi em decorrência do forte processo de grilagem e de invasões que assolavam o DF, fato que levou o então Presidente da República, Fernando Henrique Cardoso, a criar a unidade de conservação.

O Senador destacou também a preocupação com os moradores, pois eles têm previsto na constituição, o direito social à moradia. A época da instituição da unidade, em algumas partes já existia assentamentos feitos pelo próprio GDF, inclusive o Maranata. Contudo, o GDF não deu continuidade no sentido de implantar infraestrutura necessária para a efetivação do Assentamento Maranata. O político reconhece ainda que há propriedades escrituradas e que são anteriores a criação da Floresta Nacional de Brasília, como é o caso do setor Capãozinho. A preocupação maior do Senador são as grilagens, que continuam presentes no território do DF. Para ele, configura como um problema que deve ser combatido por todos. 
Já o ambientalista em sua oportunidade na audiência relatou que a ocupação intensa de terras públicas no final da década de 1980 e a preocupação de conservar os recursos hídricos, foram criadas normas e unidades de conservação sem considerar populações que já viviam nessas áreas, entre elas está a Floresta Nacional de Brasília. Por isso, o governo deve ficar atento à questão para não cometer uma injustiça social. Na ocasião o representante dos moradores lembrou que a unidade foi constituída em uma área antes ocupada por pínus e eucaliptos, que após a retirada dessas plantações foram instalados diversos assentamentos, alguns com anuência do GDF, caso notório do Assentamento Maranata, onde foram instaladas 180 famílias.

Frisa-se que em seu discurso o ambientalista apresentou uma proposta de reconfiguração da área da Floresta Nacional de Brasília, principalmente, do local onde se situa o conflito em questão. Para ele, a reconfiguração beneficiará tanto os moradores quanto o meio ambiente. Dessa forma, a proposta visa reduzir a unidade em alguns trechos e aumentar em outros. Esclareceu que a Flona 1 é a mais conservada e concentra várias nascentes, assim a sua área pode ser ampliada, beneficiando o meio ambiente. Já a área do lugar conflituoso, ou seja, a Flona 3 que abrange o Assentamento Maranata e o setor Capãozinho pode ser reduzida, beneficiando os moradores.

Na continuação da Audiência, o presidente do ICMbio enfatizou que o espaço urbano do DF está saturado e configura-se uma pressão permanente sobre o que sobrou do meio ambiente, principalmente, dos recursos hídricos. Destacou que a Floresta Nacional de Brasília delimita, justamente, as nascentes dos principais mananciais responsáveis pela formação do reservatório de água (lago Descoberto) que abastece parte da região do DF. De acordo o presidente, o Assentamento Maranata foi criado por ações oficiais do Poder Público e, desde a criação, não houve continuidade para sua regularização fundiária. Quanto ao setor Capãozinho, o representante do ICMBio reconhece que o setor possui propriedades regularizadas.

Para o presidente do ICMBio, o conflito representa uma questão complexa, pois não envolve somente órgão e moradores, envolve todo o DF. É uma responsabilidade pública e não pode ser resolvida única e exclusivamente pelos direitos dos que lutam pela área. Assim, deve ganhar, também, o meio ambiente em termos de conservação das áreas sensíveis, estratégicas, necessárias para preservar os interesses comuns e difusos do DF. Para tanto, o representante do ICMBio citou a proposta de reconfiguração da área da Floresta Nacional de Brasília, pois em determinadas áreas já não se cumpre mais o papel de conservação. 
Em seu discurso o Promotor de Justiça de Defesa do Meio Ambiente e Patrimônio Cultural defendeu o cumprimento do decreto de criação da Floresta Nacional de Brasília e dos artigos pertinentes descritos no SNUC. No que tange ao decreto de criação, esclareceu que o Poder Público fez no papel uma unidade de conservação federal, mas não regularizou a questão de transferência do domínio das terras da TERRACAP à União. Quanto ao SNUC, explanou que a unidade não possui Plano de Manejo, e que o documento é a alma da unidade de conservação, salientou que, sem ele, não existe unidade efetivamente. Na oportunidade, lembrou que a Floresta Nacional de Brasília foi criada por ato infralegal, por meio de decreto. No entanto, qualquer alteração só pode ocorrer por meio de lei. Ou seja, por ser uma unidade de conservação federal, cabe ao Congresso Nacional legislar.

Ao final da Audiência, ficou acordado o estudo de uma proposta de reconfiguração mediante procedimentos técnicos, com participação dos órgãos ambientais e dos moradores e, por fim, quando a proposta estivesse concluída, fosse feita a convocação de uma nova Audiência Pública para debatê-la. Frisa-se que até a conclusão desta dissertação, em abril de 2015, a tal proposta não havia sido elaborada.

Esse conflito traz à superfície o jogo de interesses entre os atores usuários dos recursos naturais - território - e os atores governamentais preocupados com a conservação da natureza e com as dificuldades de se conciliar desenvolvimento e conservação. Desse modo, o estudo revelou que a natureza desse conflito é social, econômica, ambiental, política e legal. É social porque busca, por parte de um dos atores do conflito, garantir o direito social à moradia, previsto na Carta Magna de 1988; é econômica, porque envolve a produção de hortifrúti para subsistência e para o comércio; é ambiental, porque visa à conservação da natureza, principalmente dos recursos hídricos para abastecimento público do DF, envolve tantos os órgãos de gestão, de fiscalização e a própria sociedade que tem interesse na conservação do manancial; é política, porque a situação do conflito favorece a projeção política dos envolvidos; é legal, porque o conflito abarca a efetivação da Floresta Nacional de Brasília com desapropriação dos imóveis e transferência das terras de domínio da TERRACAP à União, conforme prevê o decreto de criação e o SNUC.

Nesse contexto, quatro pontos importantes podem ser questionados: o primeiro ponto está na efetivação da área como, de fato, uma unidade de conservação. De acordo com os presidentes das associações do Assentamento Maranata e do setor Capãozinho, já se passaram 16 anos de criação da unidade e as suas terras ainda "pertencem" a TERRACAP. Tal motivo leva-os a questionarem a legalidade da floresta e, por consequência, a legalidade das ações do 
ICMBio. Segundo os presidentes, o órgão gestor, primeiramente com o IBAMA e a partir de 2007 com ICMBio, tem embargado e, em algumas oportunidades, mediante sentença judicial, demolido obras.

O segundo ponto está na elaboração do Plano de Manejo. O Art. $5^{\circ}$ do decreto de criação estabeleceu um prazo de dois anos contados a partir da data de publicação do decreto, para a elaboração do documento. Conforme o ICMBio (2014), o Plano de Manejo da unidade está em elaboração.

Nesse sentido, o contexto da Floresta Nacional de Brasília confirma a premissa dos parques de papel, ou seja, unidades de conservação que existem apenas nos documentos de criação. Para Pádua (2002), os governos, em seus níveis federal, estadual e municipal, criam unidades de conservação e não se esforçam para realizarem o principal, ou seja, a implementação efetiva das unidades de conservação e o manejo delas adequadamente, conforme os objetivos propostos. Os governos nem sequer se preocupam seriamente em assumir o controle das terras das unidades criadas. Por isso, as unidades de conservação são vulneráveis, pois são entendidas, no geral, como terras de ninguém. À vista disso, o território da Floresta Nacional de Brasília tem se tornado objeto de grilagem por intermédio de pessoas gananciosas.

Quanto à grilagem cabe aqui uma ponderação: é chamada de grilagem de terras a venda de terrenos alheios fracionados ou não por pessoas inescrupulosas que exercem força no processo de transformação territorial. Tal ato é previsto como crime na Lei Federal $\mathrm{n}^{\circ}$ 6.766/1979. Salienta-se que o fracionamento clandestino pode ser promovido tanto pelos moradores do terreno quanto por terceiros. Nesse sentido, durante a pesquisa de campo realizada no Assentamento Maranata, foi possível visualizar várias propriedades com inúmeras casas e delimitações, aparentemente semelhantes. Ficaram evidentes os indícios de grilagem, todavia, a identificação desses atores se torna quase impossível. Como visto, a grilagem é crime e as pessoas que praticam esses atos ilícitos, raramente, produzem provas contra eles mesmos.

O terceiro ponto trata-se da reconfiguração e da conservação dos recursos hídricos. A reconfiguração ou redução dos limites de uma unidade de conservação é prevista no $§ 7$ Art. 22 do SNUC e só poderá ser feita mediante lei específica. A reconfiguração não pode comprometer o fundamento principal da unidade, que é a conservação dos recursos hídricos, considerado pela Carta Magna de 1988 como um bem difuso, de extrema relevância à sociedade. No caso do Assentamento Maranata e do setor Capãozinho, é perfeitamente 
possível conciliar um parcelamento não urbano com atividades produtivas, agroflorestais, com manejo de solo sem comprometer a água. Contudo, é sábio reconhecer que a reconfiguração não atenderá a todos os moradores, assim, o Poder Público haverá de adotar outros instrumentos, como o reassentamento em áreas do Instituto Nacional de Colonização e Reforma Agrária. Agora, não se pode resolver a situação com medidas temporárias, ineficientes e colocar toda culpa pela degradação dos recursos hídricos apenas nas pessoas que residem na Floresta Nacional de Brasília. Observa-se que a unidade ocupa pouco mais de 9000 hectares em um universo de mais de 37000 hectares que circunda o lago Descoberto.

Destaca-se que o lago Descoberto encontra-se na divisa entre o DF e o Estado de Goiás, seu represamento iniciou-se em 1971 e foi inaugurado em 1974, é formado pelo rio Descoberto, principal canal de escoamento, pelos córregos Olaria, Chapadinha, Vendinha, Rocinha e pelos ribeirões Rodeador e das Pedras.

De acordo com Setti et al (2005), o espelho d'água do lago possui uma área de 14,8 $\mathrm{Km}^{2}$ e um volume de 102 milhões de metros cúbicos. Conforme os autores, após a construção do lago, houve a necessidade de estabelecer mecanismos de controle, pois já havia uma indicação de uso e apropriação do solo. Dessa forma, o lago Descoberto foi contemplado pelo Art. $5^{\circ}$, do Decreto $n^{\circ} 88.940 / 1983$, em que as barragens existentes ou futuras, que tenham como finalidade o abastecimento público de água, serão declaradas Áreas de Preservação Permanente. Essas áreas terão uma faixa, preservadas por lei, de 125 metros, contados a partir do espelho d'água máximo. Sendo permitida somente atividade de reflorestamento, com característica de conservação de mananciais.

Ora, constata-se que o comprometimento dos recursos hídricos é histórico, além disso vem se agravando em função do contínuo crescimento das áreas urbanas situadas em torno do lago, como as cidades de Ceilândia, Taguatinga e Brazlândia no DF e Águas Lindas no lado goiano. Segundo a CODEPLAN (2012), a soma dos habitantes dessas localidades ultrapassa os 800 mil e representam individualmente, 402.729, 199.715, 57.542 e 159.378, respectivamente. Então, a autoridade ambiental culpa uma minoria, mas se esquece de que já são 41 anos de intensa ocupação para habitação e para a produção agrícola e, como consequência, tem levado ao assoreamento do lago Descoberto.

Quanto ao assoreamento, Oliveira (2008) esclarece que o lago, em 2007, já tinha perdido boa parte da sua capacidade de armazenamento, caindo de 102 milhões de metros cúbicos para 76 milhões de metros cúbicos. A quantidade perdida, à época, daria para abastecer todas as residências do DF durante um mês. A autora obteve essas informações de 
uma reportagem do Jornal Correio Brasiliense, ocorrida no dia 25 de fevereiro de 2008, concedida pelo então Diretor de Proteção de Recursos Hídricos da CAESB.

O quarto e último ponto está na atuação dos políticos, que se apresentam nesse conflito com o interesse de projeção em suas carreiras. Primeiramente com o GDF, em 1996, que participou ativamente da ocupação do território, mas não deu seguimento no sentido de regularizar o assentamento e muito menos implantar infraestrutura básica. Salienta-se que, à época, o governo era representado por um político do Partido dos Trabalhadores, o qual exerceu o mandato no período de 1995 a 1998. Na eleição de 1998, não foi reeleito. As outras participações envolvendo o jogo de interesse se resumiram a algumas audiências públicas ou reuniões in loco na sede das associações. Como exemplo, há a audiência pública, acima citada, que foi presidida por um Senador do DF, em 2014. Esse político foi eleito governador do DF no pleito do mesmo ano da audiência.

Com relação aos moradores, atualmente, o conflito lhes é desfavorável, pois toda espécie de edificações está proibida pelo ICMBio: as casas são, em sua grande maioria, de madeirites; a energia elétrica é clandestina realizada por meio fraudulentos, ou seja, as famosas gambiarras; a água para consumo é retirada de cisternas e o lixo é depositado em buracos ou queimado pelos moradores; as vias de trânsito são estreitas e sem iluminação (Figura 16). No mesmo processo está o setor Capãozinho, com as mesmas restrições impostas pelo ICMBio aos moradores do Assentamento Maranata. Entretanto, por ser bem antigo, o setor conta com iluminação fornecida pela CEB.

Em algumas propriedades, são exercidas atividades de plantios de hortifrúti tanto para consumo próprio quanto para serem comercializados. No entanto, os produtores têm muita dificuldade para escoarem as suas mercadorias, como a área está num imbróglio, o Departamento de Estradas e Rodagem do DF não tem autorização para fazer a manutenção das estradas. Além de comprometer o transporte dos produtos, a má conservação das estradas tem trazido insegurança à população local, pois a polícia fica, praticamente, impossibilitada de transitar no local, levando assim um tempo acima do normal para atender as ocorrências.

Dessa forma, por ser a parte mais fraca do conflito, os moradores devem permanecer no embate de forma construtiva e colaborativa, de maneira a demonstrar os seus interesses em permanecer na terra. Além do mais, os moradores devem manter firme a figura do mediador, com a proposta de torná-los, cada vez mais, parceiros na conservação do meio ambiente. Para tanto, os moradores também devem propor e utilizar técnicas de plantios não nocivas ao meio 
ambiente, por exemplo, a agricultura orgânica. Assim, eles demonstram o desejo de manejar a terra sem causar lhe danos.

\section{Figura 16 - Construção de Madeirite e Rua sem Iluminação Pública no Assentamento Maranata.}

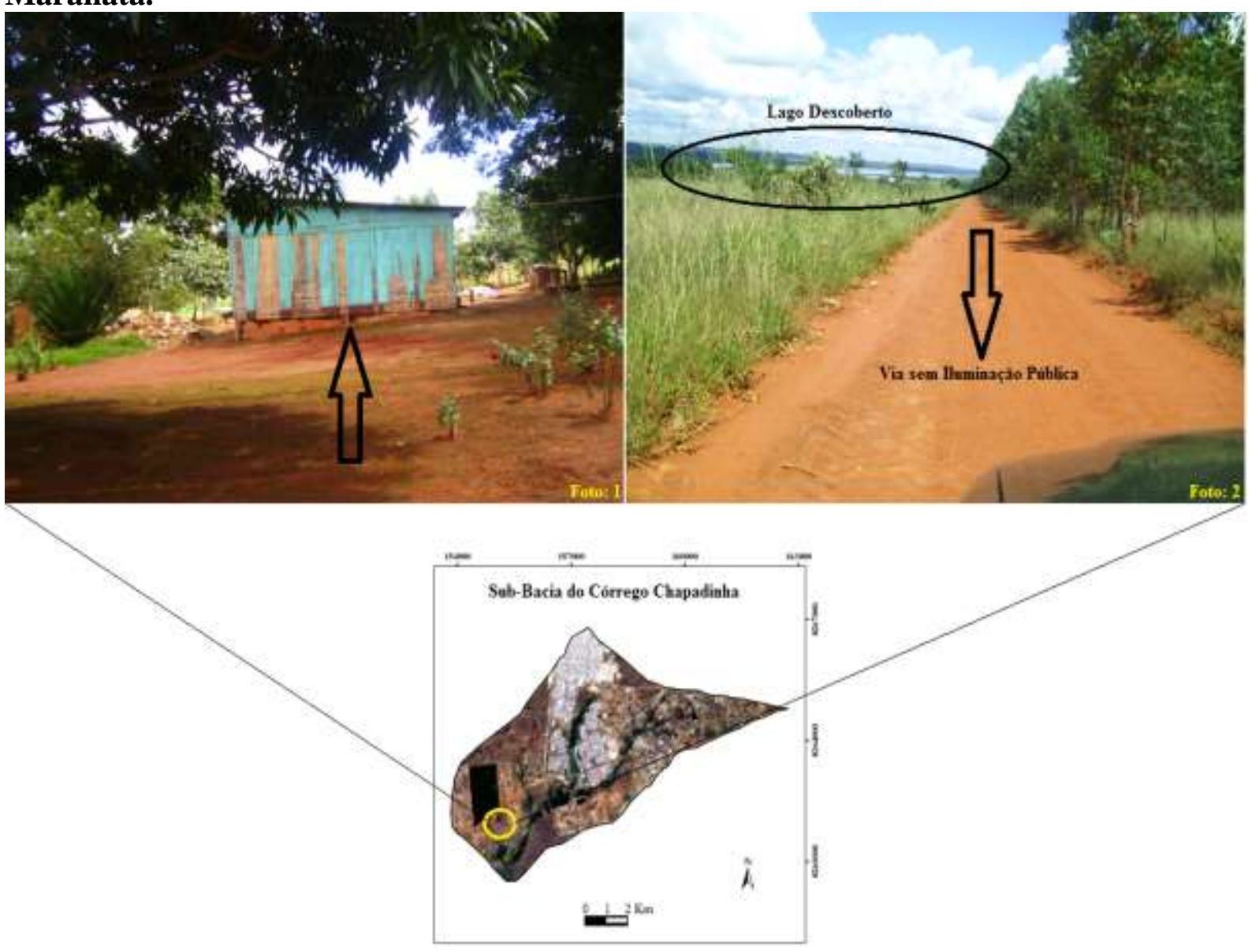

Fotografia: Gilney de Araújo Costa (Programa de Pós-Graduação em Geografia, 2014).

Data: 15 de março de 2014.

Finalmente, embora sejam inegáveis os avanços na legislação ambiental brasileira, especificamente no que diz respeito as unidades de conservação, porém são inegáveis, também, os problemas por elas ainda hoje apresentados. Esses problemas estão relacionados, principalmente, a fatores como: 1) falta de condições para a efetiva implementação das unidades (recursos humanos e financeiros, capacidade administrativa, fiscalização, elaboração e execução dos planos); 2) conflito entre instituições quanto à propriedade das terras e desapropriações (BRITO, 2000). No caso da Floresta Nacional de Brasília, todos os problemas citados estão presentes. 


\subsubsection{ASSENTAMENTO BELA VISTA}

Conforme o tópico 3.2 desta pesquisa, o Assentamento Bela Vista é derivado de uma invasão e foi erguido em uma área conhecida como Cascalheira de propriedade da TERRACAP. Outro quesito importante é que o Assentamento Bela Vista está incluído na chamada Área de Proteção Ambiental da Bacia do Rio Descoberto. Contudo, antes de qualquer coisa, torna-se fundamental, para a compreensão do processo, definir APA e caracterizar, brevemente, a APA da Bacia do Rio Descoberto.

O SNUC em seu Art. 15 define APA como:

“Área de Proteção Ambiental é uma área em geral extensa, com um certo grau de ocupação humana, dotada de atributos abióticos, bióticos, estéticos ou culturais especialmente importantes para a qualidade de vida e o bemestar das populações humanas, e tem como objetivos básicos proteger a diversidade biológica, disciplinar o processo de ocupação e assegurar a sustentabilidade do uso dos recursos naturais".

Para Milaré (2005), APAs são aquelas áreas cujo objetivo básico é compatibilizar a conservação da natureza com o uso sustentável de parcela de seus recursos naturais. Mais explicitamente, visam a conciliar a exploração do ambiente à garantia da perenidade dos recursos ambientais renováveis e dos processos ecológicos, mantendo a biodiversidade e os demais atributos ecológicos, de forma socialmente justa e economicamente viável.

Conforme visto, as APAs são unidades de uso sustentável e permitem a ocupação humana, mas desde que sejam estabelecidas normas e restrições. Salienta-se que o documento que norteia todo funcionamento das APAs é o plano de manejo. Este, sim, estabelece o zoneamento e as normas que devem presidir o uso da área e o manejo dos recursos naturais, inclusive a implantação das estruturas físicas necessárias à gestão da unidade.

Nesse sentido, por meio do Decreto Federal no 88.940/1983, foi criada a APA da Bacia do Rio Descoberto, que compreende 39100 hectares, abrange sua maior parte em áreas do DF e um pequeno trecho do Estado de Goiás. Segundo o ICMBio (2013), a APA é destinada basicamente à proteção da bacia do rio Descoberto e de seu lago, o Descoberto. A unidade abriga 7\% da Região Administrativa de Taguatinga, 67\% da RA de Brazlândia e 10\% da RA de Ceilândia. No lado do Estado de Goiás, abriga 15\% e 5\% dos municípios de Águas Lindas e de Padre Bernardo, respectivamente. No que diz respeito a gestão e a fiscalização, por ser 
uma APA federal, cabe ao ICMBio, que possui uma sede no interior da unidade, às margens da BR 070, Km 3, Taguatinga Norte.

Com relação ao Plano de Manejo da APA da Bacia do Rio Descoberto, só em 2014, 31 anos depois de sua criação, é que ele foi elaborado, a partir da Portaria $\mathrm{n}^{\circ} 133$, de 11 de dezembro. No plano, foram definidas seis zonas, descritas de forma a ordenar as atividades permitidas e não permitidas dentro de seus limites, a saber: 1) Zona de Conservação; 2) Zona de Uso Rural; 3) Zona de Controle do Adensamento Humano; 4) Zona de Contenção Urbana; 5) Zona de Uso Diversificado; e 6) Zona Urbana Consolidada.

Frisa-se que a Zona de Uso Rural é destinada a atividades rurais diversificadas, tais como agricultura, pecuária, agroindústria, turismo rural e ecológico, atividades educacionais, culturais e sociais. Entre os objetivos estão possibilitar o desenvolvimento econômico rural local e regional; reduzir os impactos sobre os mananciais hídricos e sobre a biodiversidade do Cerrado; e promover o desenvolvimento rural sustentável, respeitando os processos de recarga de aquíferos e adotando práticas de conservação do solo.

A Zona de Uso Rural é composta por quatro segmentos que apresentam restrições específicas de acordo com tamanho das propriedades: Segmento Uso Rural 1 - constituído predominantemente de lotes com área entre 2 a 5 hectares; Segmento Uso Rural 2 constituído predominantemente de lotes com área entre 5 a 10 hectares; Segmento Uso Rural 3 - constituído predominantemente de lotes com área maior que 10 hectares; e Segmento de Uso Rural Especial - constituído predominante de propriedades com lotes menores de 2 hectares, porém, são propriedades produtivas com características agrícolas.

Nota-se na Figura 17, que o Assentamento Bela Vista situa-se no Segmento Rural 1, cuja propriedades variam entre 2 a 5 hectares. De acordo com o Plano de Manejo, a regularização das propriedades situadas no Segmento Rural 1 seguirá regras específicas definidas pelo órgão titular da terra com aprovação do ICMBio, ou seja, no caso do Assentamento Bela Vista cabe à TERRACAP as medidas de regularização.

O PDOT-DF/2012 é outro importante documento que regula o uso dos territórios que estão sob a responsabilidade do GDF e da TERRACAP. Em seu Art. 87, classifica a área do Assentamento Bela Vista como Zona Rural de Uso Controlado. As atividades contidas nessa zona estão sujeitas às restrições e condicionantes impostas pela sua sensibilidade ambiental e pela proteção dos recursos hídricos destinados, exclusivamente, ao abastecimento humano. Verifica-se, então, que o PDOT/2012 corrobora com o Plano de Manejo no sentido restringir as atividades, visando à proteção, principalmente, dos mananciais. 


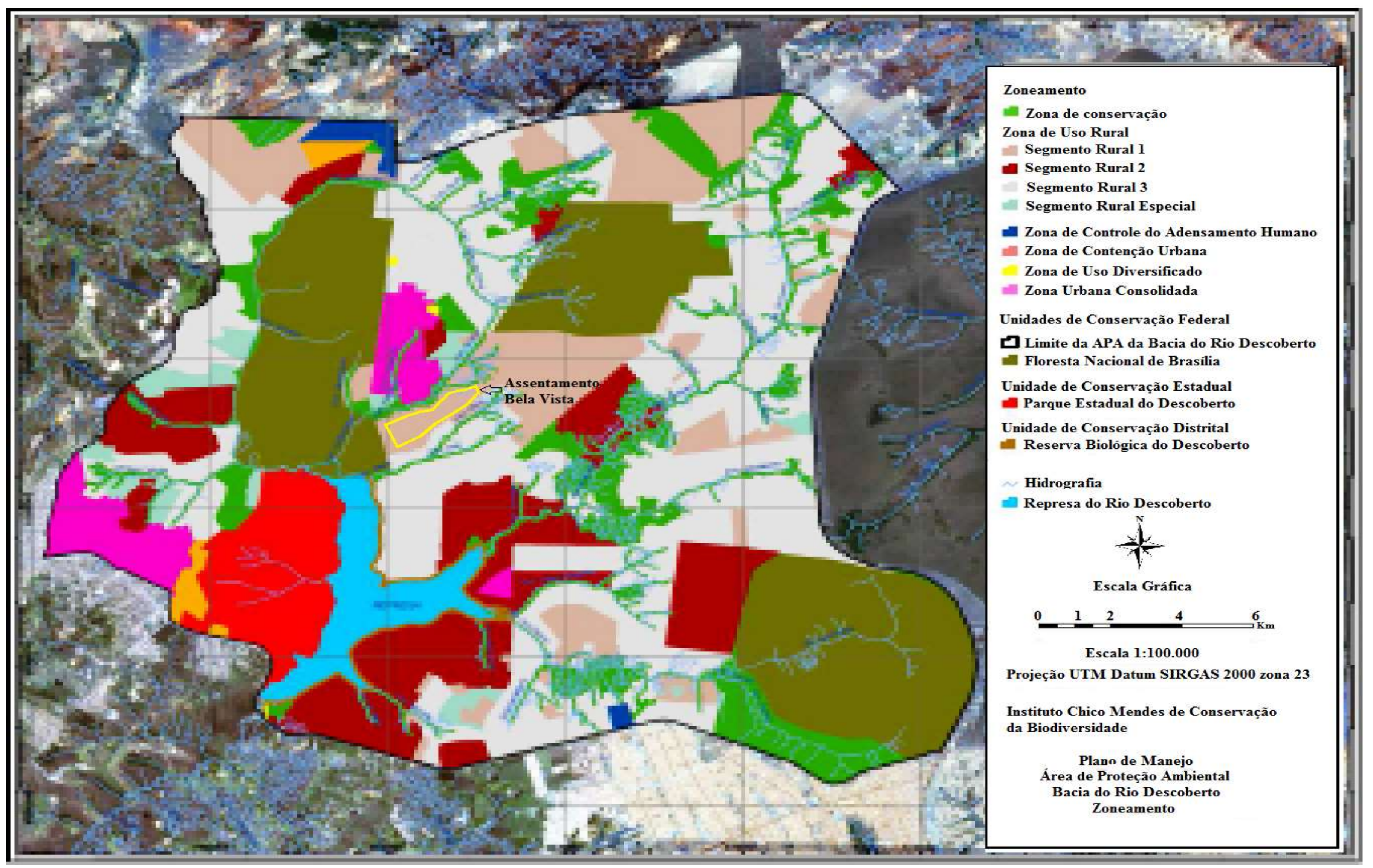

Fonte: Plano de Manejo da APA da Bacia do Rio Descoberto, página 242. 
Antes da elaboração desses documentos, o MPDFT já se mostrava preocupado com as intensas ocupações das áreas rurais do DF. Em 2006, o MPDFT firmou junto a TERRACAP o Termo de Ajustamento de Conduta (TAC) $n^{\circ} 018$ com vistas à regularização da situação das terras públicas rurais de propriedade da TERRACAP no que concerne a aspectos socioambientais e a sua fiscalização. A promotoria fez 48 considerações e, na ocasião, a companhia assumiu a obrigação de se fazer consistente no prazo de até dois anos, de promover a regularização da situação das terras rurais de sua propriedade que se encontravam ocupadas, mediante o contrato concessão de uso de terras públicas rurais.

Contudo, diante dos percalços enfrentados pela companhia para o cumprimento das obrigações ajustadas nos prazos estipulados no TAC n⿳ 18/2006, em 2011, o MPDFT e a TERRACAP firmaram um termo aditivo destinado a consolidar as cláusulas pactuadas no TAC $\mathrm{n}^{\circ}$ 018. Dessa forma, o termo ratificou o compromisso de adotar medidas e executar as ações para a regularização socioambiental das terras públicas rurais do DF, bem como o fornecimento de subsídios a serem utilizados na fiscalização do cumprimento das funções públicas a que se destinam. Entre as alterações, está o prazo estipulado para regularização, que passou de dois para cinco anos, podendo ser prorrogado por mais cinco anos, caso sobrevenham motivos técnicos e/ou jurídicos que justifiquem a prorrogação.

Nesse sentido, a TERRACAP elaborou o Contrato de Concessão de Uso Oneroso de Imóvel Rural. O documento abrange uma série de exigências, possui validade de quinze anos a partir da assinatura, sem opção de compra do imóvel por parte do contratante e impõe o pagamento do Imposto Territorial Rural. No contrato é previsto o Plano de Utilização da Unidade de Produção com a descrição de todas as atividades econômicas exercidas no imóvel, bem como as edificações e demais benfeitorias e uso sustentável. Caso o contratante não o cumpra corretamente é passível de rescisão, por exemplo, não cumprir a destinação rural, fracionar o imóvel a terceiro, impedir o acesso da fiscalização entre outras.

Atualmente, a Agência tenta firmar com os moradores o contrato, contudo, há divergências que levam a três posicionamentos diferentes por parte dos moradores. Alguns acreditam que o contrato seja uma articulação para desocupação futura, pois o documento não permite a transferência do imóvel. Outros não o assinam por não reconhecerem a TERRACAP como a verdadeira proprietária das terras. Por outro lado, diversos moradores estão assinando o contrato, acreditando que não é um documento para desocupação, pois o assentamento está, praticamente, consolidado. 
Diante do que foi exposto, percebe-se que esse conflito expõe o embate entre a comunidade local, que almeja a regularização fundiária permanente e a Agência de Desenvolvimento do DF (TERRACAP), que busca manter o domínio do território por meio do Contrato de Concessão de Uso Oneroso de Imóvel Rural, impondo regras de uso, inclusive, para evitar a degradação do meio ambiente. Assim, com base nesse contexto, na contextualização histórica de ocupação do território da Sub-bacia do Córrego Chapadinha e na caracterização dos atores, pode-se perceber que esse conflito é de natureza social, econômica, política, ambiental e legal. É social porque, em situação semelhante ao conflito anterior, a população procura garantir o direito à moradia; é econômico porque envolve, por parte da população, a produção rural e, por parte do governo, a cobrança do Imposto Territorial Rural; é político, porque vislumbraram-se, durante as negociações, interesses nos processos eleitorais; é ambiental, porque envolve o uso sustentável dos recursos naturais; e é legal, porque abrange o cumprimento dos documentos relacionados às APAs (o SNUC), aos específicos à APA da Bacia do Rio Descoberto (Decreto nº 88.940/1983 e o Plano de Manejo) e ao Contrato de Concessão de Uso Oneroso de Imóvel Rural.

Com relação aos moradores do Assentamento Bela Vista, no processo de luta por seus direitos, algumas lições podem ser extraídas: primeiramente, que a organização do grupo é essencial para a luta. Eles criaram a Associação dos Produtores Rurais do Assentamento Bela Vista, que contratou um escritório de advocacia para intermediar a permanência deles junto ao GDF e a TERRACAP. Segundo, foi a participação política dos moradores que souberam explorá-la e, dessa forma, conquistaram alguns benefícios, por exemplo, a instalação de energia elétrica, evitando assim, as instalações clandestinas. Percebe-se que, se não fosse a organização dos moradores, os avanços não poderiam ter ocorrido. No que concerne ao direito constitucional à moradia, a pesquisa de campo revelou que, diferentemente de 1996, atualmente, as edificações são de alvenarias, as vias são largas e iluminadas, conforme Figura 18. Pode-se inferir, então, a partir da infraestrutura existente, que os moradores, apesar do conflito socioambiental, sentem confiança na regularização fundiária. 
Figura 18 - Construção de Alvenaria e Via com Iluminação Pública no Assentamento Bela Vista.

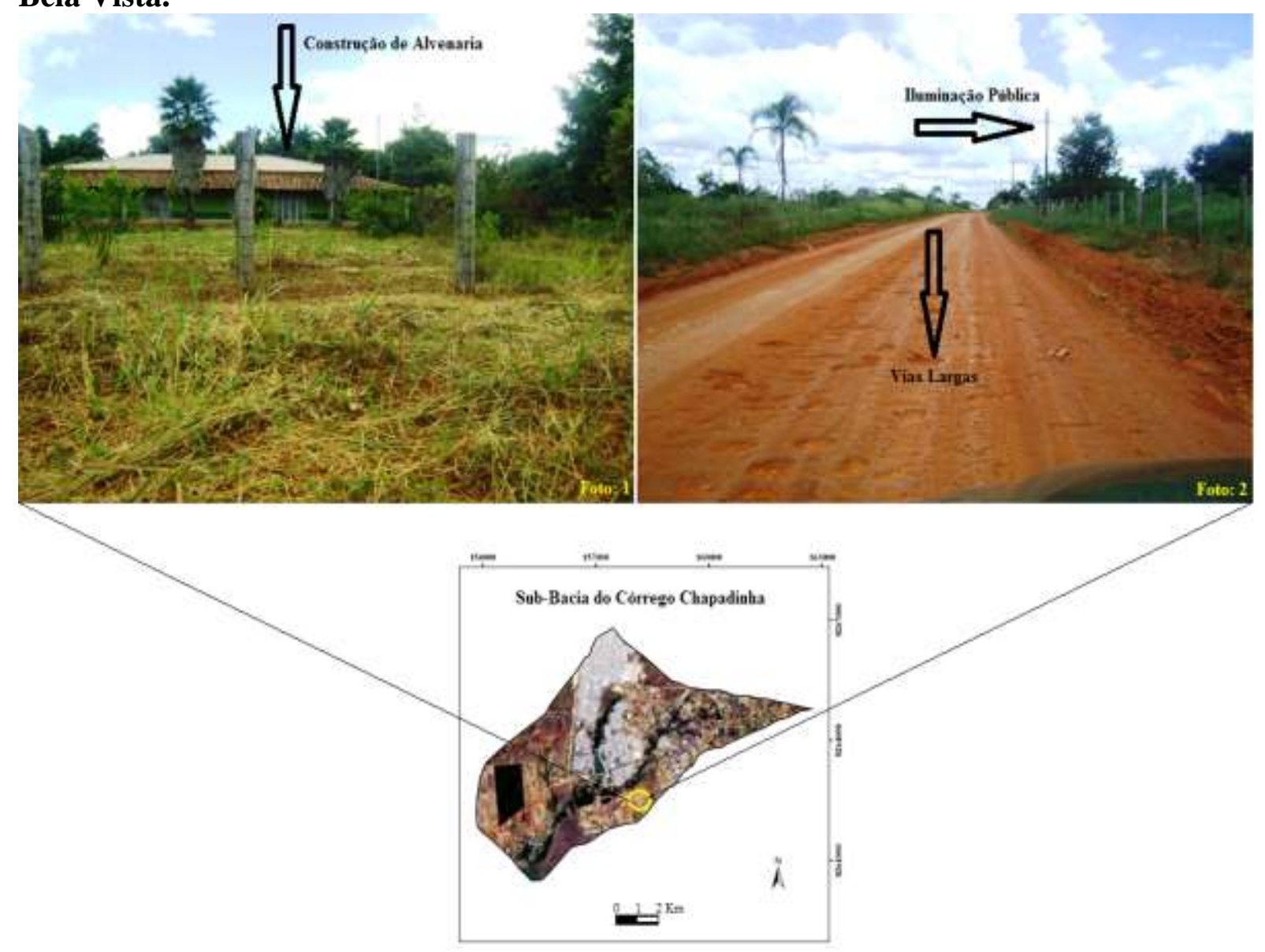

Fotografia: Gilney de Araújo Costa (Programa de Pós-Graduação em Geografia, 2014).

Data: 15 de março de 2014.

No que diz respeito aos documentos legais, faz-se referência ao fiel cumprimento do Contrato de Concessão de Uso Oneroso de Imóvel Rural, principalmente das cláusulas que obrigam o contratante a manejar os recursos ambientais com responsabilidade de maneira a não comprometê-los. Observa-se que as APAs são uma das poucas unidades de conservação que podem ser instituídas em propriedades privadas, portanto a responsabilidade pela visitação pública, pela pesquisa científica e pela efetividade de conservação é do proprietário ou, no caso do Assentamento Bela Vista, do contratante. Quanto a isso, Dourojeanni e Pádua (2007) explanam que a efetividade das APAs pode ser muito baixa ou quase nula; mas, se fossem estabelecidas com zoneamentos claros e a gestão fosse eficaz, com participação dos proprietários de terras inclusas em seus limites, poderiam funcionar adequadamente. Ainda assim, destacam os autores, as APAs, às vezes, podem ser a melhor alternativa para evitar danos ambientais ainda maiores. 
Conforme o Gráfico 10, entre algumas unidades de conservação tanto de proteção integral quanto as de uso sustentável, as APAs têm o menor valor no que se refere à conservação da biodiversidade, 10\% apenas. Para Pádua (1997), essas áreas servem como instrumento de ordenamento territorial e como medidas demagógicas, que só podem funcionar se os donos das terras quiserem exercitar o desenvolvimento sustentável.

Gráfico 10 - Valor Relativo Potencial de Algumas Categorias de Unidades de Conservação Brasileiras com a Finalidade de Preservar a Biodiversidade.
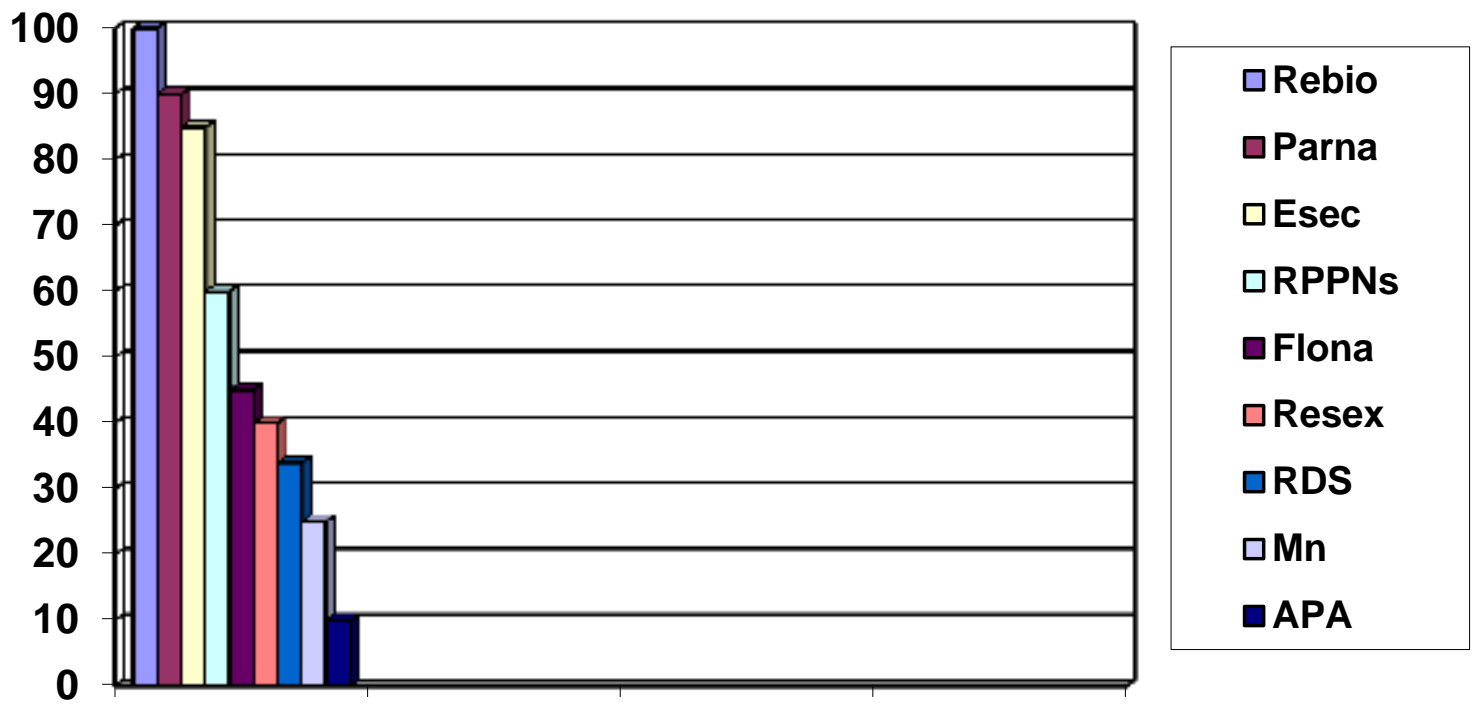

Fonte: TERBORGH E VAN SCHAIK, 1997 apud DOUROJEANNI; PÁDUA, 2007, p. 186.

Rebio - Reservas Biológicas;

Parna - Parques Nacionais;

Esec - Estações Ecológicas;

RPPNs - Reserva Particular de Patrimônio Natural;

Flona - Floresta Nacional;

Resex - Reservas Extrativistas;

RDS - Reserva de Desenvolvimento Sustentável;

Mn - Monumento Natural; e

APA - Área de Proteção Ambiental.

Nesse sentido, apesar de todo aparato legal, o ICMBio tem registrado o aumento da degradação na região da APA da Bacia do Rio Descoberto e cita, como exemplos, o escoamento inadequado de águas pluviais, o desmatamento, o acúmulo de lixo e entulho. A Figura 19 ilustra a degradação no Assentamento Bela Vista, onde o lixo é depositado a céu aberto no chão e recolhido uma vez por semana. No período chuvoso, é carreado para leito do córrego Chapadinha e, consequentemente ao lago Descoberto, gerando mais problemas de ordem ambiental. 


\section{Figura 19 - Local de Depósito de Lixo no Assentamento Bela Vista.}

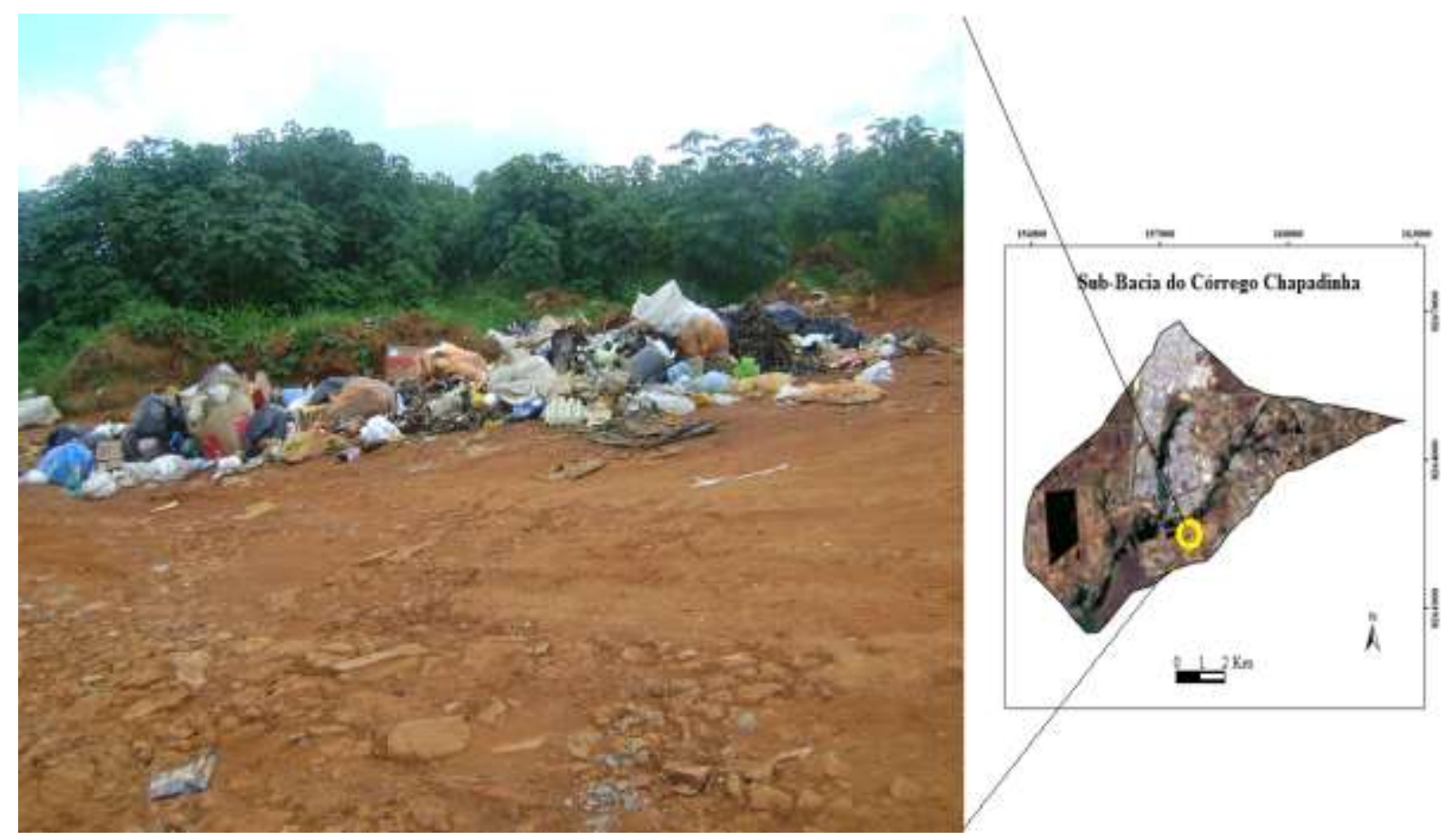

Fotografia: Gilney de Araújo Costa (Programa de Pós-Graduação em Geografia, 2014). Data: 15 de março de 2014.

Enfim, duas situações puderam ser percebidas nesse conflito. O meio ambiente foi considerado, inicialmente, com a criação da APA da Bacia do Rio Descoberto, em 1983, e foi ignorado quando surgiu o Assentamento Bela Vista, oriundo de invasão. Esse conflito deixa clara a dicotomia empregada pelas autoridades no DF: pura demagogia, simplesmente interesseira.

\subsubsection{NOVO ASSENTAMENTO, QUADRAS 33 E 34 E LOTES NOS ANTIGOS BECOS.}

Esse conflito está totalmente inserido na APA da Bacia do Rio Descoberto e desde a sua criação foi se consolidando por meio da implantação de infraestruturas básicas - água, energia e transporte. Entretanto, o Novo Assentamento e as quadras 33 e 34 são as que mais se aproximam da possibilidade de uma solução.

Nesse sentido, o PDOT (2012), por meio do Art. 117, prevê a regularização fundiária de modo a garantir à população o direito à moradia, o pleno desenvolvimento das funções sociais da propriedade urbana e o direito ao meio ambiente ecologicamente equilibrado. Já o Art. 126 trata das Áreas de Regularização de Interesse Social (ARIS). Segundo o PDOT 
(2012), as ARIS equivalem as Zonas Especiais de Interesse Social (ZEIS) nos termos da Lei federal no 10.257/2001 (Estatuto da Cidade) e têm como objetivo a regularização fundiária de assentamentos irregulares ocupados por população de baixa renda.

Segundo Soares (2012), as ZEIS constituem um tipo de zoneamento no qual são aplicadas regras especiais de uso e ocupação do solo em áreas que já foram ocupadas ou que venham a ser ocupadas por população de baixa renda a fim de garantir o direito constitucional à moradia. Elas existem em duas possibilidades: para permitir a regularização da posse de terrenos por comunidades já instaladas, aplicar as condições especiais, legalizar a situação e garantir o direito à moradia, permitindo ao poder público a realização de obras de infraestrutura. Em outros casos, existe para regular o mercado imobiliário, permitindo que populações de baixa renda usufruam das infraestruturas já instaladas em certas regiões.

Esse instrumento visa resolver questões da realidade brasileira, que inclui um processo de urbanização sem controle e apressado, a partir de uma intensa desigualdade social. As características desse processo de urbanização levaram e ainda levam as populações mais pobres a ocupar terras às margens da lei, muitas vezes em locais de conservação ambiental.

A possibilidade legal de se estabelecer um plano próprio, adequado às especificidades locais, reforça a ideia de que as ZEIS compõem um universo diversificado de assentamentos urbanos, passíveis de tratamentos diferenciados. Essa interpretação congrega a referência de qualidade ambiental para a requalificação do espaço habitado das favelas, argumento distinto da antiga postura de homogeneização, baseada rigidamente em índices reguladores.

Nesse contexto, em 2013, o GDF, por intermédio da CODHAB, realizou o recadastramento dos moradores do Novo Assentamento e das quadras 33 e 34 da Vila São José. O procedimento visou beneficiar os cidadãos que nunca possuíram imóveis registrados em seus nomes no DF. Para tanto eles precisavam comprovar que estavam residindo no imóvel há mais de cinco anos. O recadastramento findou em fevereiro de 2014 e, até o presente momento, abril de 2015, nenhum morador recebeu a escritura do imóvel. A Figura 20 e o Apêndice I evidenciam as áreas de regularização de interesse social do DF, entre elas estão o Novo Assentamento e as quadras 33 e 34 da Vila São José. 
Figura 20 - Mapa de Estratégias de Regularização Fundiária e de Ofertas de Áreas Habitacionais no DF.

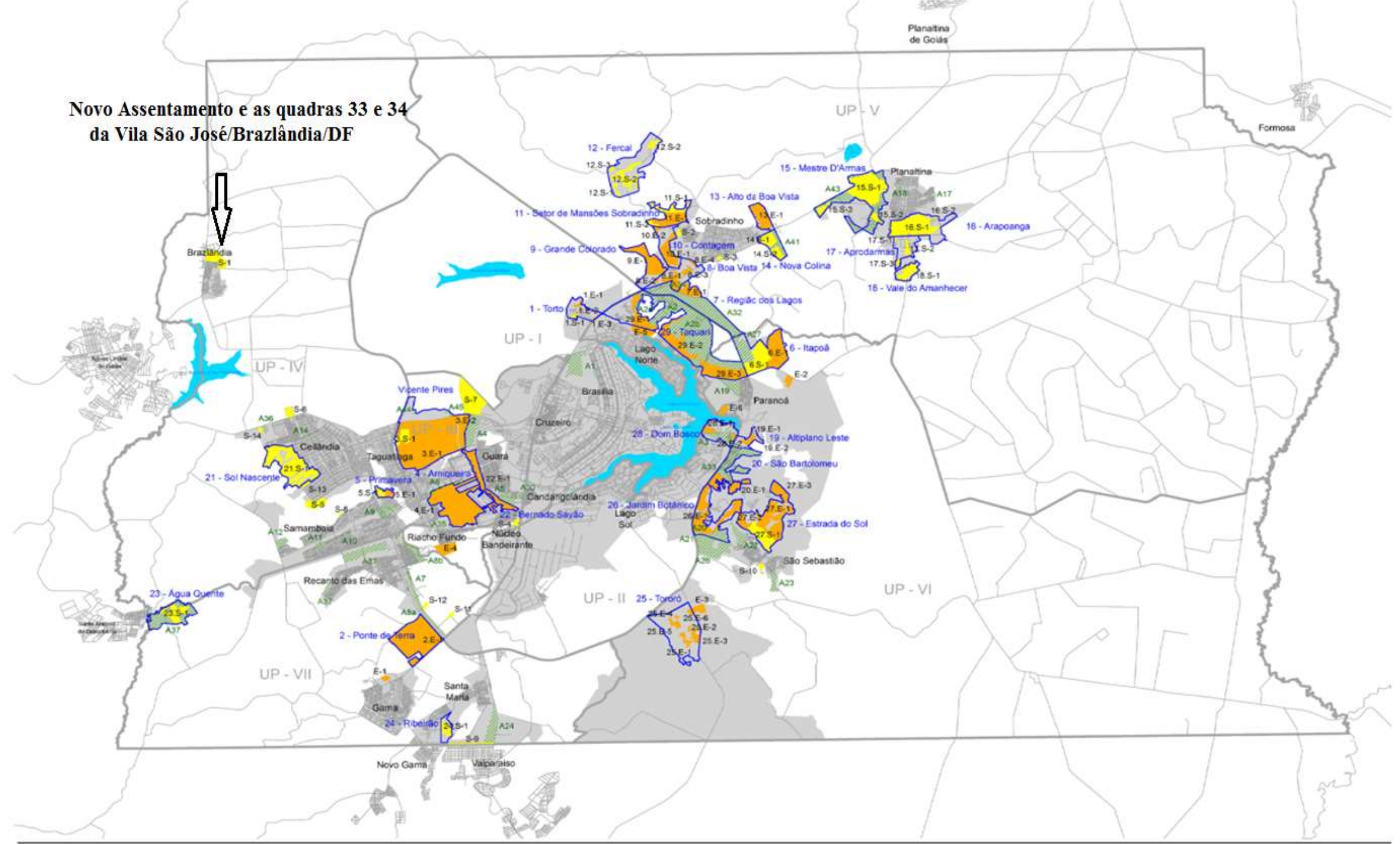

\section{Estratégias}

Oferta de Áreas Habitacionais

\section{Regularização}

$\square$ Setores Habitacionais de Regularização

Área de Regularização de Interesse Social

- Área de Regularização de Interesse Específico

\begin{tabular}{l|l}
$\square$ Unidade de Planejamento Territorial & - Sistema Viário \\
Macrozona Urbana & Lagos
\end{tabular}


Já os lotes dos antigos becos, a situação de regularização é mais complexa e demanda procedimentos específicos. De acordo com a CODHAB, os becos são áreas de uso comum da população, previsto no Plano Urbanístico de Brazlândia. A alteração de destinação para área habitacional só é possível por meio de Lei Complementar, para tanto é preciso cumprir o que determina a Lei Orgânica do DF. O passo importante é a realização de Audiência Pública para que a comunidade interessada seja ouvida. Dessa forma, foram realizadas duas Audiências, em 13 e 28 de janeiro 2014 (Apêndice J e L). Durante a segunda Audiência, o Diretor de Regularização Fundiária da CODHAB deixou claro que, após aprovado do projeto de Lei, o próximo passo deve ser a aprovação de um novo Projeto de Plano Urbanístico de Brazlândia, por meio de Decreto do GDF. Depois o Projeto Urbanístico deve ser registrado em Cartório em nome da TERRACAP e, posteriormente, o órgão deve transferir os lotes para a CODHAB, que, por sua vez, deve doar aos cadastrados. No momento, abril de 2015, o impasse continua; tais providências prometidas ainda não foram cumpridas.

No que tange aos fatores ambientais, o mapeamento, citado anteriormente no tópico 3.3 desta pesquisa, revelou que o Cerrado perdeu espaço para as áreas urbanas. Dessa forma, a construção das quadras 33 e 34, além de diminuir a vegetação, impermeabilizou o solo acima da nascente do córrego Veredinha. Em 2009, no período chuvoso, as fortes enxurradas causaram enormes danos a essas nascentes e a vegetação do Parque Ecológico Veredinha. A solução encontrada para amenizar a degradação na área do parque foi a construção de bacias de contenção para drenar as águas pluviais. Em 2009, a Companhia Urbanizadora da Nova Capital do Brasil (NOVACAP) construiu três bacias, aliás, três grandes buracos que ocupavam, aproximadamente, 2,5 hectares e não dispunham de tubulações necessárias para captação das águas e tampouco a conexão entre elas (Figura 21). Nesse mesmo ano, no período chuvoso, as bacias não suportaram o volume de água e transbordaram causando uma devastação no córrego Veredinha.

Em 2010, o MPDFT impetrou uma Ação Civil Pública contra a NOVACAP exigindo a conclusão da obra. Dois anos depois, em 2012, buscando cumprir as exigências, as obras foram retomadas, mas em 2013, novamente foram paralisadas. Frisa-se que as bacias não foram isoladas de maneira a impedir o acesso de pessoas, não foram plantadas vegetações em seus taludes para impedir a erosão e o rompimento das bacias e nem foram instaladas telas para contenção de lixos. Portanto, o descaso continua. 
Figura 21 - Parque Ecológico Veredinha, Quadras 33 e 34 e Bacias de Contenção.

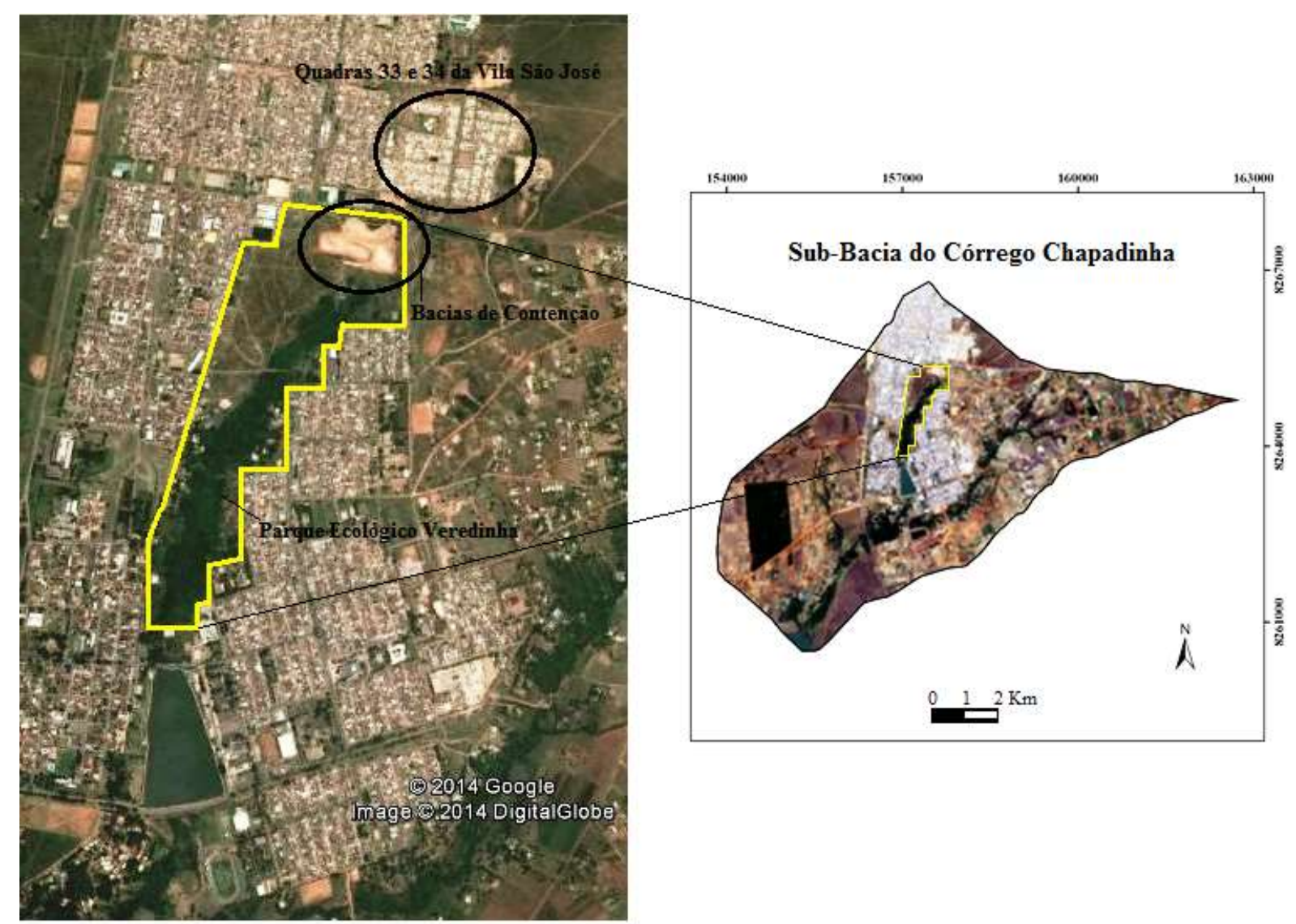

Imagem: Google Earth, 2014

Elaboração: Gilney de Araújo Costa (Programa de Pós-Graduação em Geografia, 2014).

No início deste tópico, afirmamos que as localidades - o Novo Assentamento e as quadras 33 e 34 da Vila São José - são as que mais se aproximam de uma solução. Basta para isso a vontade política, que seja sincera e que rompa de vez com as políticas atuais clientelistas e eleitoreiras. Essas áreas, há muito tempo, dispõem de toda infraestrutura necessária à sobrevivência humana, como água potável e encanada, saneamento, energia elétrica com iluminação pública, asfalto, transporte público, coleta de lixo e rede de telefonia. Cabe explicar que essas ocupações irregulares expõem a estruturação do processo de urbanização, como resultado, de um lado, da ação dos próprios moradores que, pouco a pouco, foram melhorando suas residências e implantando atividades econômicas diversas; de outro lado, advém da ação do GDF, que implantou infraestrutura a partir das necessidades e dos interesses, o que demonstra o quadro atual dessas áreas.

Logo, a efetivação das ARIS nessas localidades pode trazer resultados benéficos, sob vários aspectos: primeiro no aspecto urbanístico, pois integra áreas tradicionalmente marginalizadas e possibilita projetar espaços e equipamentos públicos para as ocupações; 
segundo, no aspecto ambiental, pois regula e diminui a ocorrência de riscos às áreas sensíveis, como os recursos hídricos; terceiro, no aspecto jurídico, pois, com a regularização fundiária, os imóveis podem ser escriturados; no aspecto econômico, fortalece-se o comércio, possibilitando a arrecadação do Imposto Predial e Territorial Urbano; e por último, o mais importante, no aspecto social, pois enfraquece o estigma que existe em relação ao assentamento e fortalece a autoestima da população que ali vive, tornando-a cada vez mais envolvida com as questões ambientais e, dessa forma, produtiva e engajada.

No capítulo que se segue são apresentadas as conclusões e as recomendações, estas estão compostas em três quadros distintos um para cada unidade de conservação - Parque Ecológico Veredinha, Floresta Nacional de Brasília e APA da Bacia do Rio Descoberto. 
CAPÍTULO 4

CONCLUSÕES E RECOMENDAÇÕES 


\section{CONCLUSÕES E RECOMENDAÇÕES}

\subsection{CONCLUSÕES}

Esta Dissertação buscou descortinar os principais conflitos socioambientais no território da Sub-bacia do Córrego Chapadinha, situado na Região Administrativa de Brazlândia. O propósito da pesquisa foi analisar os conflitos socioambientais e suas influências na dinâmica do uso do território.

Para atingir o objetivo, a pesquisa foi baseada nos conceitos de unidade de conservação, de conflitos socioambientais, de território e de uso do território. Os conceitos demarcam a íntima relação entre a questão socioeconômica e a conservação ambiental. Observa-se que, no território, as práticas de apropriação material resultam em conflitos socioambientais que, por sua vez, influenciam diretamente na dinâmica territorial.

A metodologia utilizada foi com base nas propostas de análise de Little e Nascimento. Salienta-se que a proposta possibilitou, satisfatoriamente, a compreensão dos conflitos socioambientais a partir da contextualização geográfica, ambiental e histórica com identificação dos atores, dos interesses, da natureza e chegou-se, por fim, a estruturação dos conflitos com a identificação de suas características e peculiaridades, elencando para cada situação conflitiva a questão social e ambiental em que os atores estão envolvidos. Destacase, ainda, que a pesquisa não se esgota nesta dissertação. Pode-se aprofundar a reflexão considerando cada conflito separadamente, para compreendê-lo em sua essência e realizar propostas de resolução condizentes com cada um, atendendo as especificidades de cada comunidade em que está inserido.

Em relação a hipótese, afirma-se que os conflitos socioambientais foram estruturados pela dificuldade de acesso a terra por meios legais. Tais dificuldades estimulam parte da sociedade a buscar outros mecanismos para satisfazer sua demanda social, econômica e territorial. Essas barreiras aliadas à conivência e à incapacidade de gestão por parte do Poder Público burlam as legislações vigentes - urbanística e ambiental - e fomentam o comprometimento do território da Sub-bacia do Córrego Chapadinha.

No desenvolvimento da pesquisa, percebeu-se que a ocupação irregular da área urbana de Brazlândia ocorreu concomitantemente à ocupação das áreas rurais da Sub-bacia do Córrego Chapadinha, basicamente, no mesmo período, a partir de meados da década de 1990. O detalhe importante que envolve os conflitos na Sub-bacia é o fato de que eles estão 
localizados em áreas ambientais sensíveis, essenciais para algumas atividades primordiais para os seres humanos, por exemplo, os recursos hídricos, que estão em áreas conservadas pela APA da Bacia do Rio Descoberto, pela Floresta Nacional de Brasília e pelo Parque Ecológico Veredinha.

Esta Dissertação tratou também acerca da evolução das ideias de criação das áreas protegidas no mundo. O Brasil, por sua vez, assimilou as tendências mundiais. Observa-se que, no território pesquisado, houve, em um primeiro momento, a criação das unidades de conservação, mas, em um segundo momento, uma tentativa de desapropriação. Dessa forma, torna-se inevitável o choque das estratégias entre os atores. Questões dessa natureza levaram o país a avanços significativos em sua legislação ambiental, pois a partir dos embates, as necessidades de legislação se ampliaram para a resolução dos conflitos.

Nesse sentido, é importante reconhecer a evolução obtida com a instituição do SNUC e com as diversas categorias definidas em seus artigos, inclusive as de uso sustentável. Vale lembrar, entretanto, que a maioria das categorias de uso sustentável demanda, ainda, a desapropriação dos imóveis contidos nelas. Assim, a legislação que foi instituída para ser solução acabou por criar um imbróglio. Tal fato pode ser vislumbrado na Floresta Nacional de Brasília e no Parque Ecológico Veredinha.

Outro ponto importante observado é a assimetria entre conflitos. Nesse sentido, a análise do conflito no Assentamento Bela Vista e no Assentamento Maranata possibilitou aferir que eles assumiram contornos assimétricos em suas estruturações. No Assentamento Bela Vista, a organização, por meio da associação dos moradores, a contratação de advogados e a participação política constante influenciaram na sua consolidação. No assentamento Maranata, por sua vez, houve um desdobramento diferente, pois os moradores contaram com o apoio político, somente, para a ocupação do território. Após a área ser englobada na área da Floresta Nacional de Brasília, a participação política se reduziu a interesse em época de eleição.

Além disso, é importante realçar a necessidade de maior comprometimento por parte do ICMBio. Desde o estabelecimento, em 1999, da Floresta Nacional de Brasília, o órgão gestor não elaborou o Plano de Manejo. A efetivação do Plano de Manejo poderia promover o zoneamento e, com efeito, a redução do conflito. Se o instituto nasceu com a perspectiva de trabalhar pela preservação e conservação do meio ambiente, fica também o questionamento: por que tão lento é o trabalho realizado por esse instituto? 
No que tange ao mapeamento, o método empregado se mostrou eficaz e de extrema relevância para apontar as influências dos conflitos socioambientais na dinâmica do uso do território na Sub-bacia do Córrego Chapadinha. Salienta-se, também, que a estrutura metodológica arquitetada para o desenvolvimento da pesquisa foi capaz de abarcar as diferentes fases e conduzir para o melhor resultado. Assim, elaboramos quatro mapas temáticos baseados na classificação visual das imagens do satélite Landsat 5. Associados aos mapas estão a tabela de quantificação e oito gráficos de variação das classes do uso do território. Com isso revelamos o aumento das classes antropizadas em detrimento das classes de vegetação. Em 1984, ano em que se iniciou o mapeamento, as classes de área Urbana com Alta Densidade e Cultura ocupavam 423,11 hectares, enquanto que as classes de Mata de Galeria, Reflorestamento, Pastagem, Cerrado e Campo Limpo representavam 1890,45 hectares. Em 2011, as classes antropizadas possuíam a extensão de 1434,65 hectares, já as classes com vegetação ocupavam 880,32 hectares. Destaca-se que, de todas as classes identificadas, associamos a variação de sete dessas classes - Reflorestamento, Área Urbana com Alta Densidade, Cultura, Cerrado, Pastagem, Campo Limpo e Mata de Galeria - aos conflitos socioambientais. Ademais, o mapeamento confirmou que o território da Sub-bacia do Córrego Chapadinha foi objeto de intensas invasões que ocorreram a partir da década de 1990.

Outra questão importante, atribuída ao método, é que os dados gerados podem ser utilizados continuadamente, por exemplo, estabelecer, por meio de SIG e SR, um monitoramento sistemático do uso do território para prevenção e gestão dos conflitos socioambientais.

Ao final é possível observar que o processo de uso do território coloca o espaço urbano como resultado de profundas transformações antrópicas sobre o meio físico ao longo do tempo. O caso da Sub-bacia do Córrego Chapadinha constitui mais um, entre outros no DF, que merece destaque tanto pela questão social quanto pela questão ambiental.

\subsection{RECOMENDAÇÕES}

Considerando-se os conflitos socioambientais identificados na Sub-bacia do Córrego Chapadinha, sugerem-se recomendações, as quais são apresentadas na forma dos quadros que se seguem: 


\section{Quadro 09 - Recomendações (Parque Ecológico Veredinha).}

\begin{tabular}{|c|c|c|}
\hline $\mathbf{U C}$ & Atores & RECOMENDAÇÕES \\
\hline \multirow{3}{*}{ 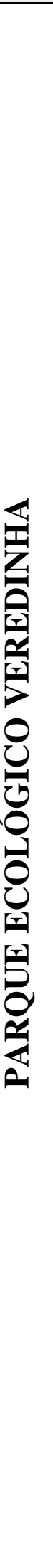 } & MORADORES & $\begin{array}{l}\text { - Aplicação do tratamento diálogo/cooperação, } \\
\text { apresentado por Little (2001) no tópico } 1.3 \text { desta } \\
\text { dissertação. Assim, articular-se com o poder público na } \\
\text { formulação de instrumentos e mecanismos legítimos } \\
\text { para resolução do conflito; } \\
\text { - Os moradores, também, podem cooperar na vigilância e } \\
\text { na fiscalização subsidiando o IBRAM na coibição de } \\
\text { possíveis invasões e degradação da natureza. }\end{array}$ \\
\hline & NOVACAP & $\begin{array}{l}\text { - Realizar a manutenção periódica das bacias de contenção } \\
\text { de águas pluviais, com a instalação de telas nas manilhas } \\
\text { para impedir o acúmulo de lixos e evitar o entupimento } \\
\text { das mesmas; } \\
\text { - Consertar as telas que cercam o parque, principalmente } \\
\text { as que estão perto das bacias e que foram danificadas } \\
\text { pelas chuvas, em 2009; } \\
\text { - Isolar as bacias para conter o fluxo de pessoas que as } \\
\text { usam para banho e outras atividades. }\end{array}$ \\
\hline & IBRAM & $\begin{array}{l}\text { - Intensificar a fiscalização no interior do parque e em } \\
\text { seus arredores no sentido de coibir as degradações e } \\
\text { possíveis invasões; } \\
\text { - Plantar vegetação no talude das bacias de contenção, } \\
\text { para evitar erosões; } \\
\text { - Estabelecer convênio com o IBAMA para soltura de } \\
\text { animais apreendidos, uma vez que o parque está ilhado e } \\
\text { impossibilitado de promover o fluxo de genes de animais } \\
\text { terrestres como pequenos mamíferos, répteis e anfíbios; } \\
\text { - Atualizar o Plano de Manejo que é de } 2006 \text {, levando em } \\
\text { consideração a nova realidade do parque, inclusive a } \\
\text { construção das quadras } 33 \text { e } 34 \text { da Vila São José e das } \\
\text { bacias de contenção, ambas em } 2009 \text {; } \\
\text { Estabelecer por meio de SIG e SR, um sistema de } \\
\text { monitoramento do uso do território para prevenção e } \\
\text { gestão do conflito socioambiental. }\end{array}$ \\
\hline
\end{tabular}


Quadro 10 - Recomendações (Área de Proteção Ambiental da Bacia do Rio Descoberto).

\begin{tabular}{|c|c|c|c|}
\hline $\mathbf{U C}$ & Local & Atores & RECOMENDAÇÕES \\
\hline \multirow{5}{*}{ 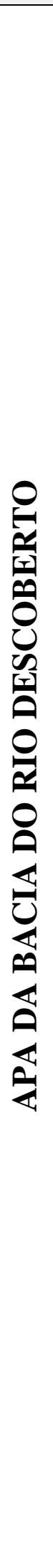 } & \multirow{2}{*}{ 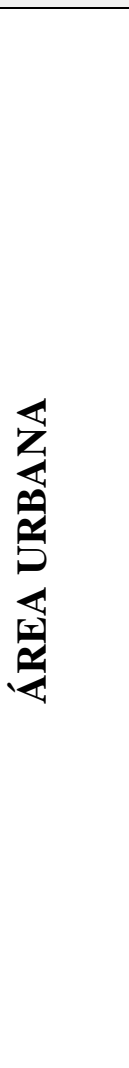 } & CODHAB & $\begin{array}{l}\text { - Regularizar a áreas urbanas consolidadas (Novo } \\
\text { Assentamento e as quadras } 33 \text { e } 34 \text { da Vila São } \\
\text { José) cumprindo o descrito no Art. 126, PDOT } \\
\text { 2012, que trata das Áreas de Regularização de } \\
\text { Interesse Social, por meio de ações prioritárias, de } \\
\text { modo a garantir o direito à moradia, o pleno } \\
\text { desenvolvimento das funções sociais da propriedade } \\
\text { urbana. }\end{array}$ \\
\hline & & GDF & $\begin{array}{l}\text { - Aprovar por meio de decreto um novo Plano } \\
\text { Urbanístico de Brazlândia, alterando a destinação } \\
\text { dos becos de áreas de uso comum do povo, para } \\
\text { área habitacional; } \\
\text { - Propor projeto de lei complementar para } \\
\text { regularização dos lotes nos antigos becos, } \\
\text { destinando-os aos moradores que neles residem; }\end{array}$ \\
\hline & \multirow{2}{*}{ 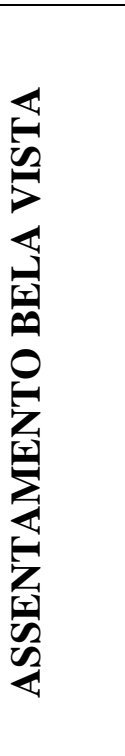 } & MORADORES & $\begin{array}{l}\text { - Firmar com a TERRACAP o Contrato de Concessão de } \\
\text { Uso Oneroso de Imóvel Rural; } \\
\text { - Participar da vigilância e da fiscalização no sentido de } \\
\text { coibir novas invasões e a degradação da natureza; } \\
\text { - Oferecer denúncia caso seja observado indícios de } \\
\text { grilagem. }\end{array}$ \\
\hline & & TERRACAP & $\begin{array}{l}\text { - Promover palestras junto aos usuários dos imóveis } \\
\text { para esclarecimentos das dúvidas relacionadas ao } \\
\text { Contrato de Concessão de Uso Oneroso de Imóvel } \\
\text { Rural; } \\
\text { - Aumentar o prazo de vigência do contrato. }\end{array}$ \\
\hline & & ICMBio & $\begin{array}{l}\text { - Intensificar a fiscalização na APA, bem como em } \\
\text { seus arredores no sentido de coibir invasões, } \\
\text { grilagem e a degradação da natureza; } \\
\text { - Implementar ações para repovoar as áreas de } \\
\text { pastagens com espécies nativas do Cerrado. }\end{array}$ \\
\hline
\end{tabular}




\section{Quadro 11 - Recomendações (Floresta Nacional de Brasília).}

\begin{tabular}{|c|c|c|}
\hline $\mathbf{U C}$ & Atores & RECOMENDAÇÕES \\
\hline \multirow{4}{*}{ 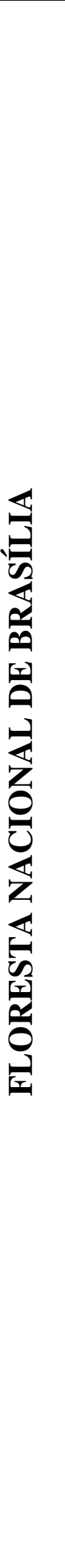 } & MORADORES & 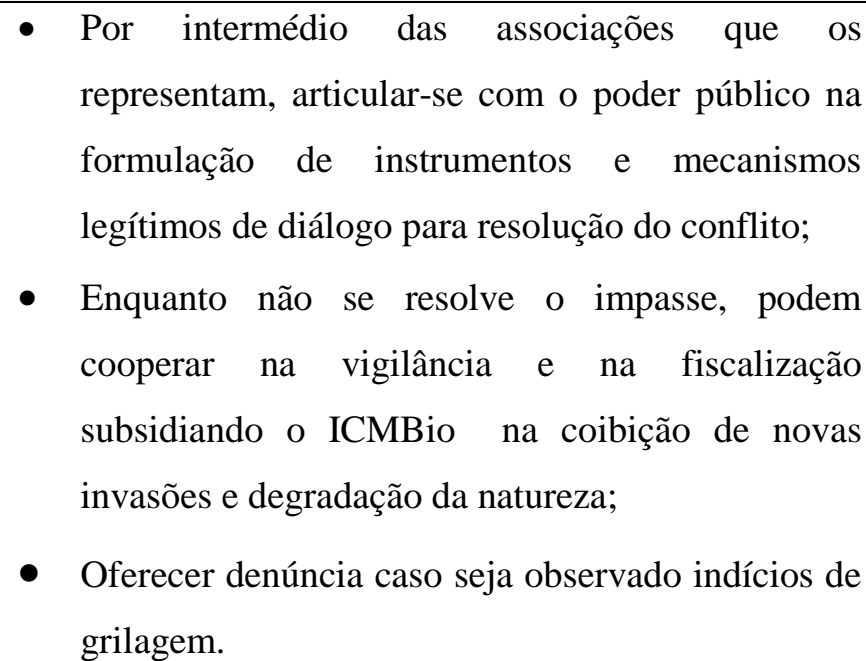 \\
\hline & TERRACAP & $\begin{array}{l}\text { - Cumprir o disposto na Cláusula Sétima do TAC de } \\
04 \text { de maio de 1998, em que a TERRACAP é } \\
\text { obrigada, mediante doação, transferir o domínio } \\
\text { das terras da Floresta Nacional de Brasília à } \\
\text { União. }\end{array}$ \\
\hline & ICMBio & $\begin{array}{l}\text { - Cumprir o Art. } 27 \text { do SNUC e o Art. } 5^{\circ} \text { do decreto } \\
\text { de criação, os quais determinam a elaboração e } \\
\text { implantação do Plano de Manejo. O documento } \\
\text { deve ser pautado com o Roteiro Metodológico } \\
\text { para Elaboração de Plano de Manejo para } \\
\text { Florestas do MMA/IBAMA; } \\
\text { - Implementar ações para repovoar as áreas de } \\
\text { pastagens com espécies nativas do Cerrado; } \\
\text { - Intensificar a fiscalização na interior da unidade } \\
\text { de conservação, bem como em seus arredores no } \\
\text { sentido de coibir novas invasões, grilagem e a } \\
\text { degradação da natureza; } \\
\text { Estabelecer por meio de SIG e SR, um sistema de } \\
\text { monitoramento do uso do território para prevenção } \\
\text { e gestão do conflito socioambiental. }\end{array}$ \\
\hline & $\begin{array}{c}\text { CONGRESSO } \\
\text { NACIONAL }\end{array}$ & $\begin{array}{l}\text { - Continuar servindo como campo para as } \\
\text { discussões que envolvem os embates na área da } \\
\text { Floresta Nacional de Brasília. }\end{array}$ \\
\hline
\end{tabular}




\section{REFERÊNCIAS BIBLIOGRÁFICAS}

ALBAGLI, Sarita. "Território e Territorialidade". In: BRAGA, Christiano; LAGES, Vinícius Nobre; MORELLI, Gustavo (orgs). Territórios em Movimentos: cultura e identidade como estratégia de inserção competitiva. Brasília: Relume Dumará, 2004. p. 23 - 62.

ANJOS, Rafael Sanzio Araújo. Dinâmica Territorial. Cartografia - Monitoramento - Modelagem. Brasília - Distrito Federal - Mapas Editora e Consultoria, 2008 - Brasil.

Monitoramento do Crescimento e Vetores de Expansão de Brasília. PAVIANI, Aldo et al (orgs). Brasília 50 Anos da Capital a Metrópole. Brasília: Editora Universidade de Brasília, 2010. p. $369-395$.

ANJOS, Rafael Sanzio Araújo et al. Mapeamento do Uso da Terra no Distrito Federal - 1964. Revista Espaço \& Geografia, Vol. 5, nº 1 (2002) - Brasília, DF. Departamento de Geografia. p. 233 247.

ARAÚJO, Marcos Antônio Reis. Unidades de Conservação no Brasil - Da República à Gestão de Classe Mundial. Belo Horizonte: Segrac, 2007.

BARRETO, Cristiane Gomes; GIUSTINA, Christian Della. Unidades de Conservação do Distrito Federal. Centro de Desenvolvimento Sustentável da Universidade de Brasília, 2008. 40 Pág.

BATISTA, Roberto Carlos. "Ambiente e Saúde: direitos humanos e fundamentais interdependentes". In: BATISTA, Roberto Carlos; THEODORO, Suzi Huff; ZANETI, Izabel (orgs.). Direito Ambiental e Desenvolvimento Sustentável. Rio de Janeiro: Lúmen Júris, 2008. pp. 19 - 33.

BRAGA, Maria Lúcia de Santana; PIRES, Mauro Oliveira. "Parques Ecológicos e População no Distrito Federal: à procura da "natureza" e do lazer". In: DUARTE, Laura Maria Goulart; THEODORO, Suzi Huff (orgs.). Dilemas do Cerrado: entre o ecologicamente (in)correto e o socialmente (in)justo. Rio de Janeiro: Garamond, 2002. p. 27 - 56.

BRASIL. Constituição (1988). Constituição da República Federativa do Brasil: 1988. In: MEDAUAR, Odete. Coletânea de Legislação Ambiental: Constituição Federal. $7^{\mathrm{a}}$ Ed. São Paulo: Revista dos Tribunais, 2008.

Decreto Federal $\mathbf{n}^{\mathbf{0}} \mathbf{8 8 . 9 4 0}$, de 07 de novembro de 1983, dispõe sobre a criação das Áreas de Proteção Ambiental das Bacias dos Rios São Bartolomeu e Descoberto.

Decreto Federal $\mathbf{n}^{0} \mathbf{1 . 2 9 8}$, de 27 de outubro de 1994, que aprova o regulamento das Florestas Nacionais, e dá outras providências.

Decreto Presidencial s/no $\mathbf{n}^{\mathbf{0}}$ de 10 de junho de 1999, autoriza a União a aceitar doação de imóveis que menciona, cria a Floresta Nacional de Brasília, e dá outras providências.

Lei $\mathbf{n}^{\circ}$ 4.545, de 10 de dezembro de 1964, dispõe sobre a reestruturação administrativa do Distrito Federal, e dá outras providências. 
Lei $\mathbf{n}^{\mathbf{0}}$ 5.861, de 12 de dezembro de 1972, autoriza o desmembramento da Companhia Urbanizadora da Nova capital do Brasil - NOVACAP, mediante alteração de seu objeto e constituição da Companhia Imobiliária de Brasília - TERRACAP, e dá outras providências.

Lei $\mathbf{n}^{0}$ 6.394, de 09 de dezembro de 1976, dispõe sobre a participação do Governo do Distrito Federal no capital da PROFLORA S.A. - Florestamento e Reflorestamento.

Lei $\mathbf{n}^{\circ}$ 49, de 25 de outubro de 1989, altera a administração do Distrito Federal, extingue órgãos, e dá outras providências.

Lei $\mathbf{n}^{\mathbf{0}} \mathbf{6 . 7 6 6}$, de 19 de dezembro de 1979, dispõe sobre o parcelamento do solo urbano e da outras providências.

Lei $\mathbf{n}^{\mathbf{0}} \mathbf{7 . 7 3 5}$, de 22 de fevereiro de 1989, dispõe sobre a extinção de órgão e de entidade autárquica, e cria o Instituto Brasileiro do Meio Ambiente e dos Recursos Naturais Renováveis.

Lei $\mathbf{n}^{\mathbf{0}} \mathbf{9 . 9 8 5}$, de 18 de julho de 2000, dispõe sobre o Sistema Nacional de Unidades de Conservação da Natureza.

Lei $\mathbf{n}^{\mathbf{0}}$ 11.516, de 28 de agosto de 2007, dispõe sobre a criação do Instituto Chico Mendes de Conservação da Biodiversidade.

BRITO, Daguinete Maria Chaves. Conflitos em Unidades de Conservação. PRACS: Revista de Humanidades do Curso de Ciências Sociais UNIFAP. N. 1 dez 2008.

BRITO, Daguinete Maria Chaves et al. Conflitos socioambientais no século XXI. Revista de Humanidades do Curso de Ciências Sociais da UNIFAP Macapá, n. 4, p. 51-58, dez. 2011.

BRITO, Maria Cecília Wey de. Unidades de Conservação: intenções e resultados. São Paulo: Annablume/FAPESP, 2000. pp. 17-111.

BURSZTYN, Marcel. A Difícil Sustentabilidade: Política energética e conflitos ambientais. Rio de Janeiro: Ed. Garamond, 2001. p. 259.

CABRAL, Cláudio Américo. "A Usina Hidrelétrica de Itá e o Movimento dos Atingidos pelas Barragens". In: BURSZTYN, Marcel. (org.). A Difícil Sustentabilidade: Política energética e conflitos ambientais. Rio de Janeiro: Ed. Garamond, 2001. p. 243 - 256.

CÂMARA, Gilberto et al. Anatomia de Sistemas de Informação Geográfica. 1997, v. único.

CAMPOS, Neio. “A Segregação Planejada”. IN PAVIANI, Aldo (org). A Conquista da Cidade: movimentos populares em Brasília. 2 ${ }^{a}$ Ed. Brasília: Editora da Universidade de Brasília, 2010, p. 109 130.

CAVAlCANTE, Shelma Regina et al. Ordenamento Territorial e Plano Diretor: o caso do distrito federal. Cadernos ASLEGIS. 2008. Câmara dos Deputados. P. 78 - 97.

CIDADE, Lúcia C. F.; PELUSO, Marília L. Sociedade Contemporânea e Conflitos Urbanos em Brasília. Espaço \& Geografia, Brasília, vol.15, no 2 (2012), p. 265-282. 
CHAVES, Weber José Neiva. Brazlândia, agricultura e identidade: fragarias da festa do morango e da reificação triunfante da mercadoria ao simulacro e a venda sem charme dos ambulantes. 2011. 134 p. Dissertação (Mestrado em Geografia) - Departamento de Geografia. Universidade de Brasília, DF.

CODEPLAN. Distrito Federal em Síntese - Informações socioeconômicas e geográficas, 2012/ Companhia de Planejamento do Distrito Federal (Codeplan). Brasília: Codeplan, 2012. p. 78.

CORREIO BRAZILIENSE. Invasões Desafiam Fiscais, Terça-feira, 18 fev. 2014. p. 23

COSTA, Gilney de Araújo. A Degradação Ambiental e a Qualidade da Água na Bacia do Rio Descoberto. 2009. 65p. Monografia (Especialização em Desenvolvimento Sustentável e Direito Ambiental) - Centro de Desenvolvimento Sustentável. Universidade de Brasília.

COSTA, Graciete Guerra. As regiões Administrativas do Distrito Federal de 1960 a 2011. 2003. 536 p. Tese (Doutorado em Arquitetura e Urbanismo) - Faculdade de Arquitetura e Urbanismo. Universidade de Brasília, DF.

DAVENPORT, Lisa; RAO, Madhu. "A história da proteção: paradoxos do passado e desafios do futuro". In: TERBORGH, John; SCHAIK, Carel Van; DAVENPORT, Lisa; RAO, Madhu (orgs.). Tomando os parques eficientes: estratégias para a conservação da natureza nos trópicos. Curitiba: UFPR/Fundação O Boticário, 2002. pp. 52-73.

DIEGUES, Antônio Carlos. O Mito Moderno da Natureza Intocada. $3^{\text {a }}$ ed. São Paulo: Hucitec, 2000.

DISTRITO FEDERAL. Decreto $\mathbf{n}^{0}$ 16.052, de 07 de novembro de 1994, o qual regulamentou a Lei $\mathrm{n}^{\circ}$ 302, de 26 de agosto de 1992, que autorizou a criação e instalação do Parque Ecológico Veredinha.

Decreto $\mathbf{n}^{\circ}$ 28.620, de 24 de dezembro 2007, declara de utilidade pública, para fins de desapropriação, área situada no imóvel CHAPADINHA, parte do quinhão 13, destinada a modernização do sistema viário do Distrito Federal e preservação ambiental.

Decreto $\mathbf{n}^{\mathbf{0}}$ 30.044, DE 11 de fevereiro de 2009, anula o Decreto $\mathrm{n}^{\circ} 28.620$, de 24 de dezembro de 2007.

Lei $\mathbf{n}^{\mathbf{0}}$ 302, de 26 de agosto de 1992, autoriza o Poder Executivo a criar, instalar o Parque Ecológico Veredinha, em Brazlândia, e dá outras providências.

Lei $\mathbf{n}^{\mathbf{0}}$ 353, de 18 de novembro de 1992, aprova o Plano Diretor de Ordenamento Territorial do Distrito Federal - PDOT.

Lei Complementar $\mathbf{n}^{\mathbf{0}}$ 17, de 28 de janeiro de 1997, aprova o Plano Diretor de Ordenamento Territorial do Distrito Federal - PDOT.

Lei Complementar $\mathbf{n}^{\mathbf{0}}$ 265, de 14 de dezembro de 1999, dispõe sobre a criação de Parques Ecológicos e de uso múltiplo no Distrito Federal, DF.

Lei Complementar $\mathbf{n}^{\mathbf{0}} \mathbf{8 0 3}$, de 25 de abril de 2009, aprova a revisão do Plano Diretor de Ordenamento Territorial do Distrito Federal - PDOT e dá outras providências. 
Lei Complementar $\mathbf{n}^{\mathbf{0}}$ 827, de 22 de julho de 2010, que institui o Sistema Distrital de Unidade de Conservação da Natureza - SDUC.

. Lei Complementar $\mathbf{n}^{\mathbf{0}} \mathbf{8 5 4}$, de 15 de outubro de 2012, atualiza a Lei Complementar $\mathrm{n}^{\circ} 803$, de 25 de abril de 2009, que aprova a revisão do Plano Diretor de Ordenamento Territorial do Distrito Federal - PDOT e dá outras providências.

DORST, Jean. Antes que a natureza morra. São Paulo: Edgar Blucher. 1973. p. 91-114.

DOUROJEANNI, Marc Jean; PÁDUA, Maria Tereza Jorge. Biodiversidade a Hora decisiva. $2^{\mathrm{a}}$ Ed. Curitiba: UFPR, 2007.

DOYLE, Patrícia Colela. "Comercialização de Habitações Populares em Brasília". IN PAVIANI, Aldo (org). Brasília Moradia e Exclusão. Brasília: Editora Universidade de Brasília, 1996. p. 115 138.

DUARTE, Laura Maria Goulart; LEONARDO, Othon H.; THEODORO, Suzi Huff. "Cerrado: o celeiro saqueado". In: DUARTE, Laura Maria Goulart; THEODORO, Suzi Huff (orgs.). Dilemas do Cerrado: entre o ecologicamente (in)correto e o socialmente (in)justo. Rio de Janeiro: Garamond, 2002. p. $145-173$.

FILHO, Milton da Costa Araújo; MENESE, Paulo Roberto; SANO, Edson Eyji. Sistema de Classificação de Uso e Cobertura da Terra com Base na Análise de Imagens de Satélite. Revista Brasileira de Cartografia n ${ }^{\circ}$ 59/02, p. 171-179, ago. 2007.

FITZ, Paulo Roberto. Geoprocessamento sem Complicação. São Paulo: Oficina de Textos, 2008.

FLORENZANO, Teresa Gallotti. Iniciação em Sensoriamento Remoto. 2a edição, São Paulo: Oficina de Textos, 2007.

FLORES, Pedro Maury et al. Análise Multitemporal da Expansão Agrícola no Município de Barreiras - Bahia (1988 - 2008). Campo-Território: revista de geografia agrária, v. 7, n. 14, p. 1-19, ago. 2012.

FRANCO, José Luiz de Andrade; SCHITTINI, Gilberto de Menezes. "História das Áreas Protegidas: objetivos e justificativas para a proteção da natureza". In: Gercinair Silvério Gandara. (org.). Rios e Cidades. Olhares da História e Meio Ambiente. 1ª ed. Goiânia: PUC Goiás, 2010, v. p. 203 - 227.

GANEM, Roseli Senna; LEAL, Zita de Moura. "Parques do Distrito Federal: desafios à sua implantação". In: DUARTE, Laura Maria Goulart; THEODORO, Suzi Huff (orgs.). Dilemas do Cerrado: entre o ecologicamente (in)correto e o socialmente (in)justo. Rio de Janeiro: Garamond, 2002. p. $57-70$.

GONZALES, Suely Franco Netto. A Gestão Urbanística do Espaço Habitado: o objeto e o método no caso do Distrito Federal. PAVIANI, Aldo et al (orgs). Brasília 50 Anos da Capital a Metrópole. Brasília: Editora Universidade de Brasília, 2010. p. 163 - 193. 
IBIAPINA, Izabel. Conflitos em Áreas Protegidas na Amazônia: o caso do Parque estadual Monte Alegre. 2012. 150 p. Dissertação (Mestrado em Desenvolvimento Sustentável) - Centro de Desenvolvimento Sustentável. Universidade de Brasília, DF.

IBRAM. Plano de Manejo do Parque Ecológico Veredinha. Brazlândia. Distrito Federal.2006.

ISAIAS, Fábio Bakker. A Sustentabilidade da Água: proposta de um índice de sustentabilidade de bacias hidrográficas. 2008. 168 p. Dissertação (Mestrado em Desenvolvimento Sustentável) - Centro de Desenvolvimento Sustentável. Universidade de Brasília.

LITTLE, Paul E. "Os Conflitos Socioambientais: um Campo de Estudo e de Ação Política”. In: BURSZTYN, M. (org.). A Difícil Sustentabilidade: Política energética e conflitos ambientais. Rio de Janeiro: Ed. Garamond, 2001. p. 107-122.

MACHADO, Paulo Affonso Leme. Direito Ambiental Brasileiro. 17 ${ }^{\mathrm{a}}$ ed. São Paulo: Malheiros Editores, 2009.

MATIAS-PEREIRA, José. Manual de Metodologia da Pesquisa Científica. $2^{\text {a }}$ Ed. São Paulo: Atlas, 2010.

MÉLO, Thelma Santos. "Linha de Transmissão Itumbiara/Brasília". (org.) BURSZTYN, M. In: A Difícil Sustentabilidade: Política energética e conflitos ambientais. Rio de Janeiro: Ed. Garamond, 2001. p. 233-242.

MERCADANTE, Maurício. "Uma década de debate e negociação: a história da elaboração do SNUC”. In: Benjamin, Antônio Herman (coord.), Direito ambiental das áreas protegidas: o regime jurídico das unidades de conservação. Rio de Janeiro, Forense Universitária. 2001. pp. 190-231.

MILANO, Miguel Serediuk et al. Unidades de Conservação: atualidades e tendências 2004. Curitiba: Fundação O Boticário de Proteção à Natureza, 2004. 208p.

MILARÉ, Edis. Direito do Ambiente: doutrina, jurisprudência, glossário. 4 ed. São Paulo: Editora Revista dos Tribunais, 2005.

MORSEllo, Carla. Áreas Protegidas Públicas e Privadas: seleção e manejo. São Paulo: Annablume/FAPESP, 2001. pp. 66-200.

NASCIMENTO, Elimar Pinheiro. "Os Conflitos na Sociedade Moderna: uma Introdução Conceitual". In: BURSZTYN, M. (org.). A Difícil Sustentabilidade: Política energética e conflitos ambientais. Rio de Janeiro: Ed. Garamond, 2001. p. 85-105.

OLIVEIRA, Virgênia Maria Bezerra. O Papel da Educação Ambiental na Gestão dos Recursos Hídricos: caso da bacia do lago Descoberto. 140 p. Dissertação (Mestrado em Geografia) Departamento de Geografia. Universidade de Brasília, DF.

PÁDUA, Maria Tereza Jorge. Sistema Nacional de Unidades de Conservação: de onde viemos e para onde vamos? Anais do I Congresso Brasileiro de Unidades de Conservação. Vol. I. Curitiba, IAP; UNILIVRE; Rede Nacional Pró-Unidades de Conservação, 1997. pp. 214-236. 
. "Unidades de Conservação: muito mais do que atos de criação e planos de manejo". In: MILANO, Miguel S. (org.). Unidades de Conservação: atualidades e tendências. Curitiba: Fundação o Boticário de Proteção à Natureza, 2002. pp. 3-13.

REVISTA CORREIO BRAZILIENSE. Brasília em Três Tempos. Terça-feira, 19 abr. 2005.

RICHARDSON, Roberto Jarry. Pesquisa Social Métodos e Técnicas. $3^{\text {a }}$ Ed. São Paulo: Atlas, 2011.

SANTOS, Milton. Metamorfoses do Espaço Habitado. $6^{\text {a }}$ ed. São Paulo: Editora da Universidade de São Paulo, 2008.

SCHAIK, Carel Van; TERBORGH, John. "Por que o Mundo Necessita de Parques". In: TERBORGH, John; SCHAIK, Carel Van; DAVENPORT, Lisa; RAO, Madhu (orgs.). Tomando os parques eficientes: estratégias para a conservação da natureza nos trópicos. Curitiba: UFPR/Fundação $O$ Boticário, 2002. pp. 25-36.

SETTI, Arnaldo Augusto et. al. O Saneamento no Distrito Federal: aspectos culturais e socioeconômicos. $1^{\text {a }}$ ed. Brasília, 2005.

SOUSA, Nilton Goulart. Conflitos Sócio-Ambientais na Micro-Bacia Hidrográfica do Córrego Samambaia, no Distrito Federal. 2009. 122 p. Dissertação (Mestrado em Geografia) - Departamento de Geografia. Universidade de Brasília, DF.

UNESCO. Vegetação do Distrito Federal: tempo e espaço. $2^{\text {a }}$ Ed. Brasília: UNESCO, 2002.

VASCONCELOS, Adirson. As Cidades Satélites de Brasília. Brasília: Centro Gráfico do Senado Federal, 1988.

VEIGA, José Eli; ZATZ, Lia. Desenvolvimento Sustentável: que Bicho é esse? São Paulo: Autores Associados, 2008.

VERÍSSIMO, Mônica. Metodologia de Zoneamento Ambiental Área de Estudo: APA Gama Cabeça-de-Veado. 2003. 339 p. Tese (Doutorado em Geologia) - Instituto de Geociências. Universidade de Brasília, DF.

VIEIRA, Paulo Freire; VIVACQUA, Melissa. Conflitos socioambientais em Unidades de Conservação. Revista Política \& Sociedade, nº 07, outubro de 2005. pp. 139-162.

\section{CONSULTAS ELETRÔNICAS}

BRASIL. SENADO FEDERAL. Audiência Pública: Floresta Nacional de Brasília. Disponível em: $<$ http//www.19senado.gov.br/sdleg-getter//public/getdocument?docverid=c23788b-23eb-4a03-82a1862b0f9f89ff:1.0.html>. Acesso em: 17 de julho de 2014.

BRAZLÂNDIA. Conheça Brazlândia RA-IV. Disponível em: $<$ http//www.brazlandia.df.gov.br/sobre-a-ra-iv/conheça-brazlandia-ra-iv.html>. Acesso em: $27 \mathrm{de}$ novembro de 2013. 
CAESB. APA do Descoberto e o Termo de Cooperação. Disponível em: $<$ http//www.caesb.df.gov.br/component/content/article/11-portal/caesb-ambiental/64-a-apa-dodescoberto.html>. Acesso em: 27 de novembro de 2013.

CODHAB. A Companhia. Disponível em: <http://www.codhab.df.gov.br/Conteudo/pag_int.aspx?codConteudo=2.html>. Acesso em: $20 \mathrm{de}$ novembro de 2013.

EMATER. Informações Agropecuárias do Distrito Federal. Empresa de Assistência Técnica e Extensão Rural/DF (Gerência de Programação e Orçamento/GEPRO) /CPLAN. 2013. Disponível em: <http://www.emater.df.gov.com.html>. Acesso em: 20 de outubro de 2014.

EMBRAPA. Levantamento de Reconhecimento de Solos de Alta Intensidade do Alto Curso do Rio Descoberto, DF/GO, escala 1:100.000. Planaltina: Embrapa Cerrados, 2003. Disponível em: <http://www.cpac.embrapa.br/publicacoes/bolpd.html>. Acesso em: 20 de novembro de 2013.

Relação entre as Classes de Solos e as Principais Fitofisionomias do Alto Curso do Rio Descoberto, Distrito Federal e Goiás. Planaltina: Embrapa Cerrados, 2003. Disponível em: <http://www.cpac.embrapa.br/publicacoes/bolpd.html>. Acesso em: 20 de novembro de 2013.

FLÓSCULO, Frederico. O Terceiro PDOT de 2012: como mudar (para melhor) o futuro de Brasília. Disponível em: http://www.brasil247.com/pt/247/brasilia247/75868/O-terceiro-PDOT-de2012-como-mudar-\%28para-melhor\%29-o-futuro-de-Bras\%C3\%ADlia.html. Acesso em: 20 de novembro de 2013.

GANEM, Roseli Senna; VIANA, Maurício Boratto. Apas Federais no Brasil. Câmara dos Deputados Federais. Consultoria Legislativa. Brasília, 2005. Disponível em: <http://www.camara.leg.br/documentos-e pesquisas/publicações/estnottec/tema14/-consultorialegislativa-999.pdf.html>. Acesso em: 20 de novembro de 2013.

IBAMA. Definições conceituais. Disponível em: <http://www.ibama.gov.br/html>. Acesso em: 27 de novembro de 2013.

IBRAM. Projeto Mapear. Disponível em <http://www.ibram.df.gov.br/component/content/article/256-atas/276-projeto-mapear.html>. Acesso em: 20 de novembro de 2013.

Base Jurídica. Disponível em: <http://www.ibram.df.gov.br/institucional/basejuridica.html>. Acesso em: 20 de novembro de 2013.

ICMBio. APA da Bacia do Rio Descoberto. Disponível em: $<$ http//www.icmbio.gov.br/portal/biodiversidade/unidadesdeconservacao/biomasbrasileiros/cerrado/un idades-de-conservacao-cerrado/2055-apa da-bacia-do-rio-descoberto.html>. Acesso em: 27 de novembro de 2013.

ICMBio. Plano de Manejo da APA da Bacia do Rio Descoberto. Disponível em: $<$ http//www.icmbio.gov.br/portal/biodiversidade/unidadesdeconservacao/biomasbrasileiros/cerrado/un idades-de-conservacao-cerrado/2055-apa da-bacia-do-rio-descoberto.html>. Acesso em: 18 de janeiro de 2015.

O Instituto. Disponível em: <http://www.icmbio.gov.br/portal/quem-somos/oinstituto.html>. Acesso em: 27 de novembro de 2013. 
MPDFT.

Ação

Civil

Pública.

Disponível

em:

http://www.mpdft.mp.br/comunicação/site/arquivos/ACP_Veredinha.PDF. html acesso em 17 de julho de 2014.

Recomendação no 51/1999. Disponível em: http://www.mpdft.mp.br/portal/index.php/mpdftacao/recomendacoes-menu/800-promotoria-de-justica-de-defesa-da-ordem-urbanistica-prourb. $\mathrm{html}$ acesso em 17 de julho de 2014.

NOVACAP. A NOVACAP. Disponível em: <http://www.novacap.df.gov.br/sobre-a-novacap/anovacap.html>. acesso em 19 de março de 2014.

SOARES, Nicolau. Zeis e Direito à Moradia: as leis que alguns escolhem ignorar. <http://www.redebrasilatual.com.br/blogs/desafiosurbanos/2012/02/zeis-e-direito-a-moradia-asleisque-alguns-escolhem-não-ver>. Acesso em: 27 de novembro de 2013.

TERRACAP. A TERRACAP. Disponível em: <http://www.terracap.df.gov.br/portal/institucional/aterracap>. Acesso em: 27 de novembro de 2013. 
APÊNDICES 


\section{APÊNDICE A}

Mapa do Plano Estrutural de Ordenamento Territorial do DF/1978.

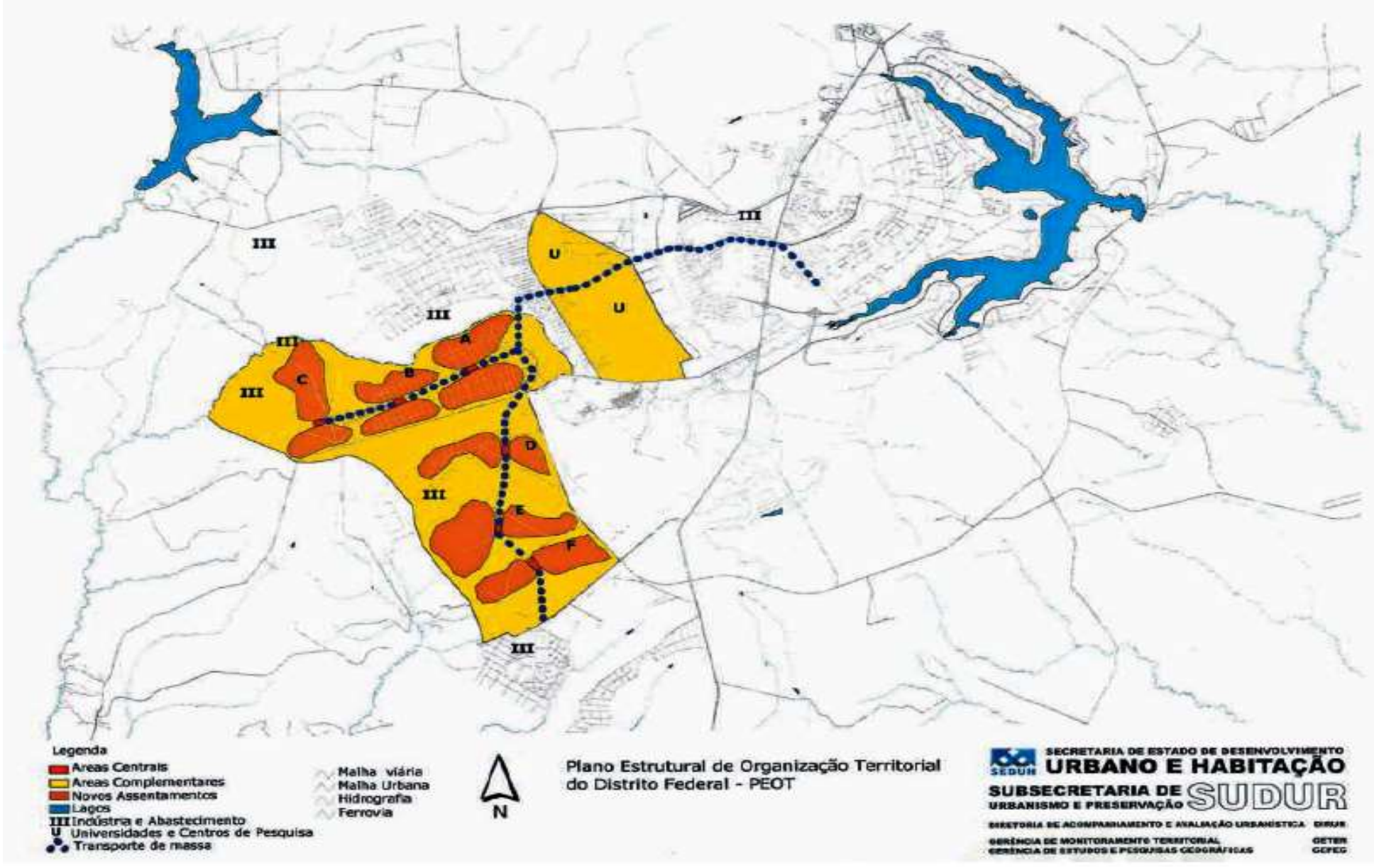

Fonte: COSTA, Graciete Guerra. As regiões Administrativas do Distrito Federal de 1960 a 2011. 


\section{APÊNDICE B}

Mapa do Plano de Ocupação Territorial do DF/1985.

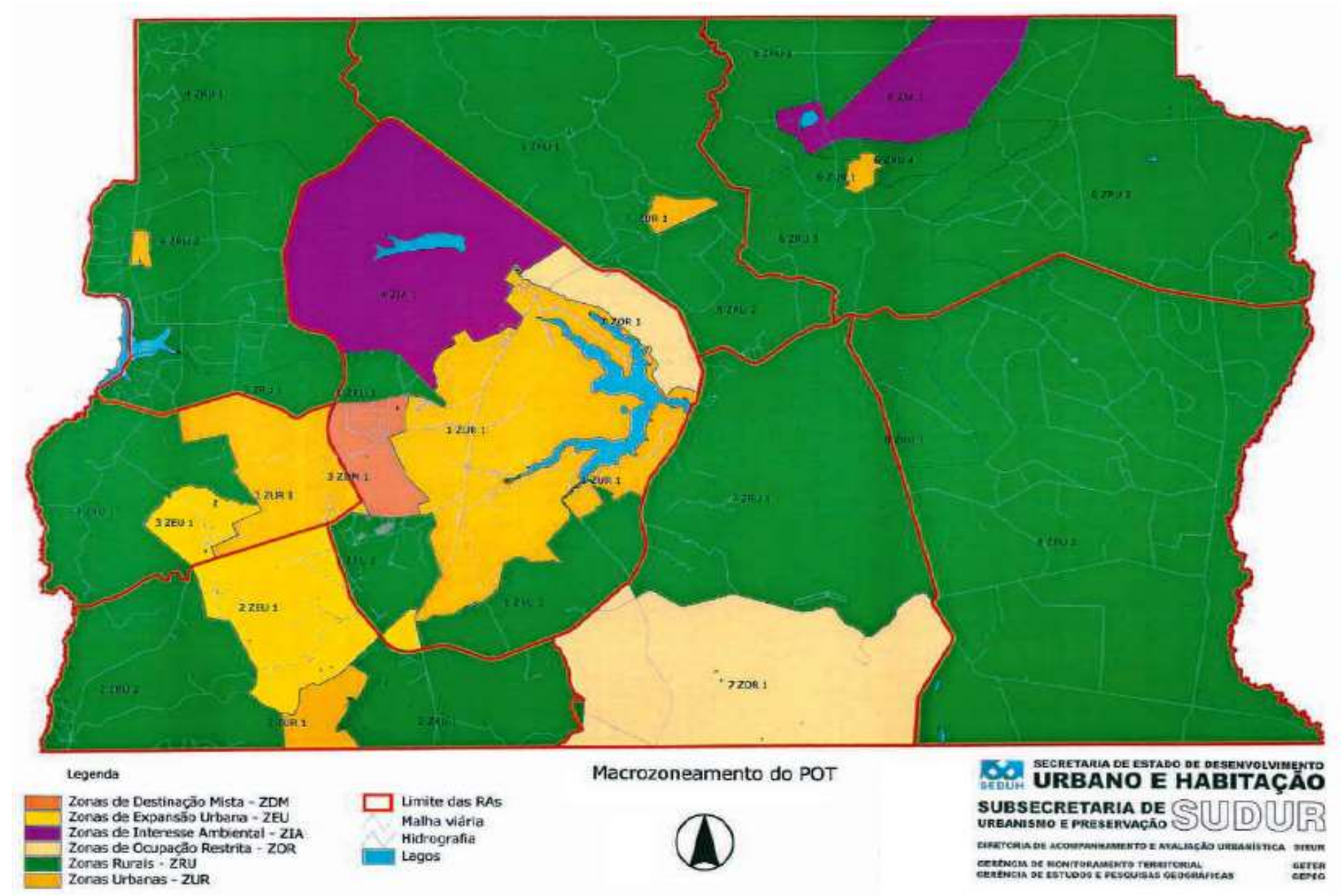

Fonte: COSTA, Graciete Guerra. As regiões Administrativas do Distrito Federal de 1960 a 2011. 


\section{APÊNDICE C}

Proposta Brasília Revisitada - 1985/1987.

PRoposta: BRAsílı ReVistrada

$\square$ Área A-BAIRRO OESTE SUL (SHCSW) Quachras econônicas (piloti +
Centro cho bairro- (2 pav. Sempilotis)

Área B-BAIRRO OESTE HORTE (SHCHW)

$$
\text { Análogo ao B airro Oeste Sul }
$$

área C- QUADRAS PLAHALTo

Quactras menores, pilotis e 4 pav. Vila

Área D-QUADRA DAEPIA (SHEP)

Quactras menores, pilotis +4

Área E- ASA Hova SUL (SHB)

Quactras menores, pilotis $\mathrm{e} 4$
pavimentos.

$\square$ Área F-ASA HOVA HORTE (SHTO)

Quachras econônicas e conjuntos
geminactos (hab. Popular), quadras (jilotis 4 pavimentos) e lotes indivictuais, fixaçăo da atual Vila Paranoá.

MSPW -6 resiclencias por lote

\section{ALTERAÇÕES:}

Quackras Planatto - revogadlas pela
decisăo 111/88 - CAUMA

B airro Oeste Horte - (SHCrm) - Redurido deviclo à criação do Parque Ecológico H orte PqEH

Howas Homenclaturas - URB 89/89

SHCrW - Setor Hab. Coletivas Horoeste

SHEP - Setor Hab. Estracka Parque

SHB - Setor Hab. Buritis

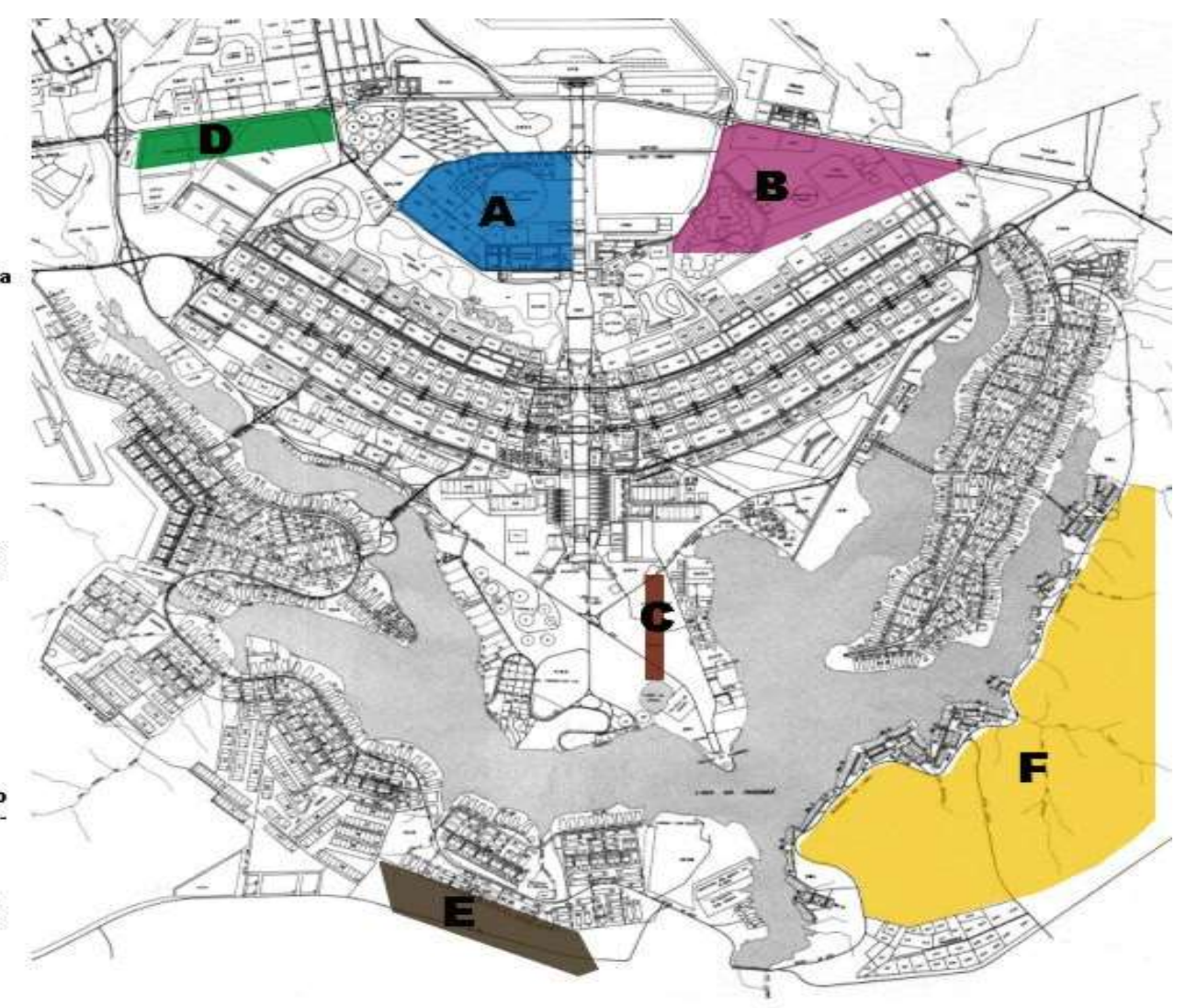

Fonte: Brasília Revisitada 1985/87 (Anexo I do Decreto nº 10.829/1987 - GDF e da Portaria nº 314/1992 - Iphan). 


\section{APÊNDICE D}

Mapa do Plano de Ocupação e Uso do Solo do DF/1990.

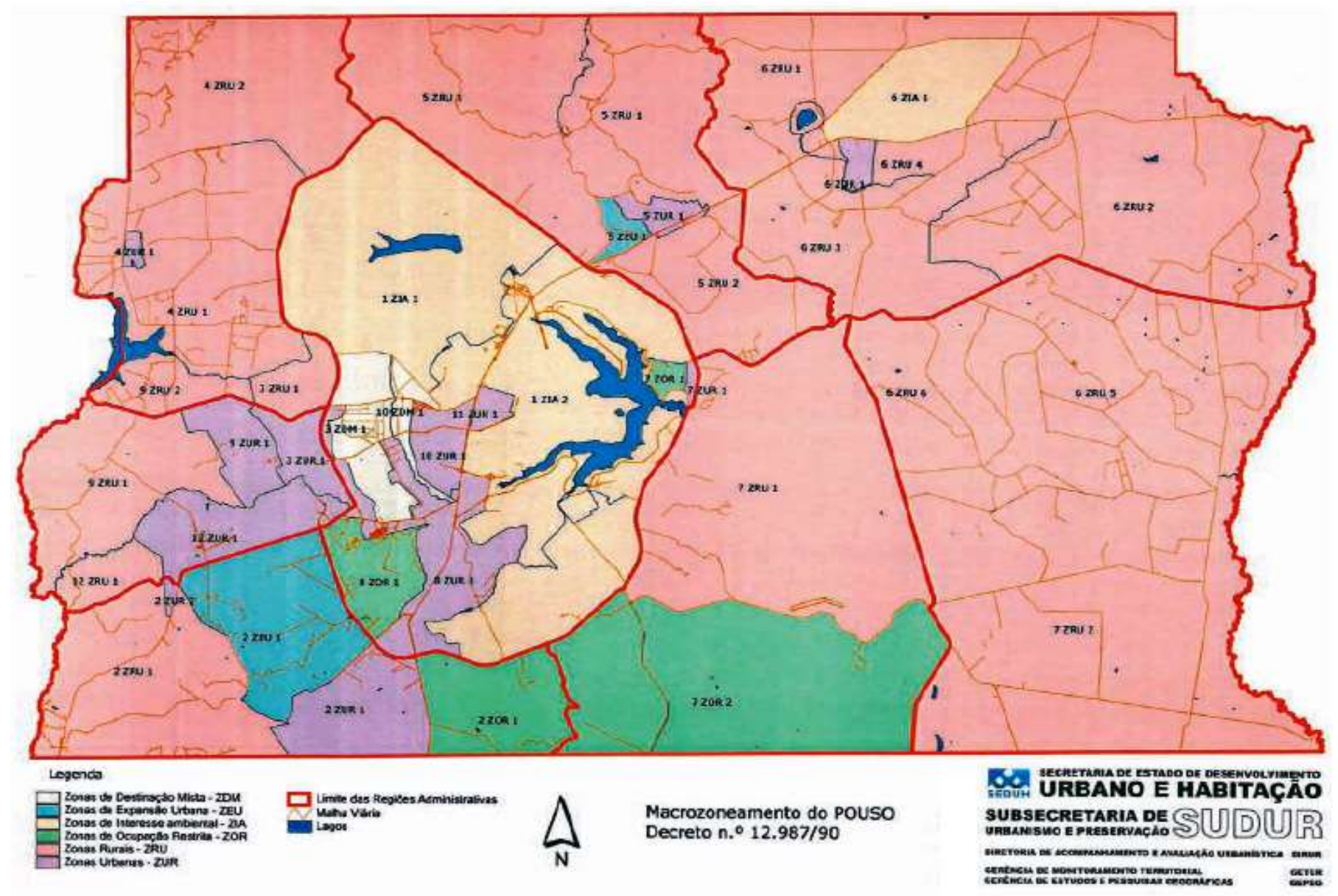

Fonte: COSTA, Graciete Guerra. As regiões Administrativas do Distrito Federal de 1960 a 2011. 


\section{APÊNDICE E}

\section{Mapa do Plano Diretor de Ordenamento Territorial do DF/1992.}

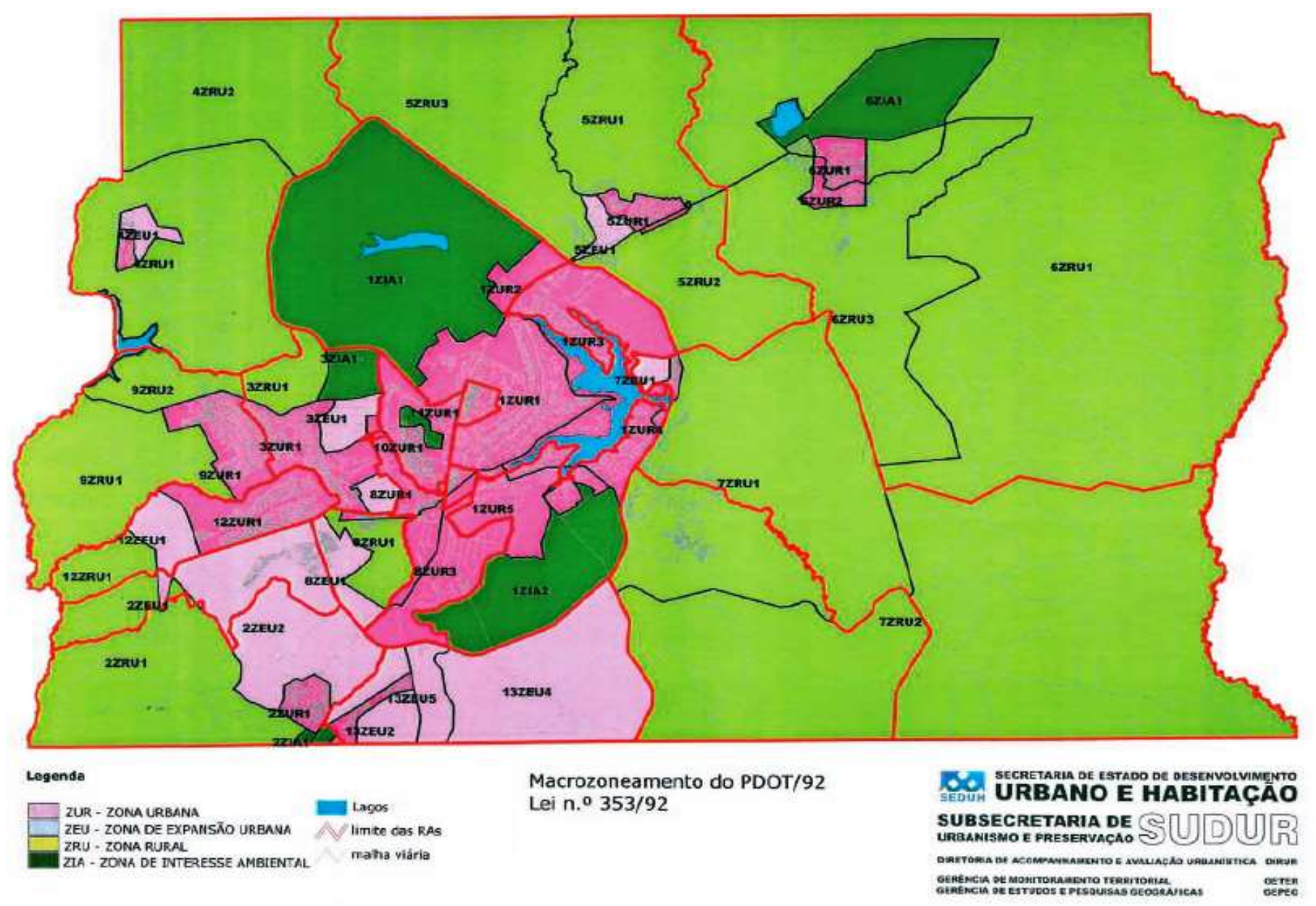

Fonte: COSTA, Graciete Guerra. As regiões Administrativas do Distrito Federal de 1960 a 2011 


\section{APÊNDICE F}

Mapa do Plano Diretor de Ordenamento Territorial do DF/1997.

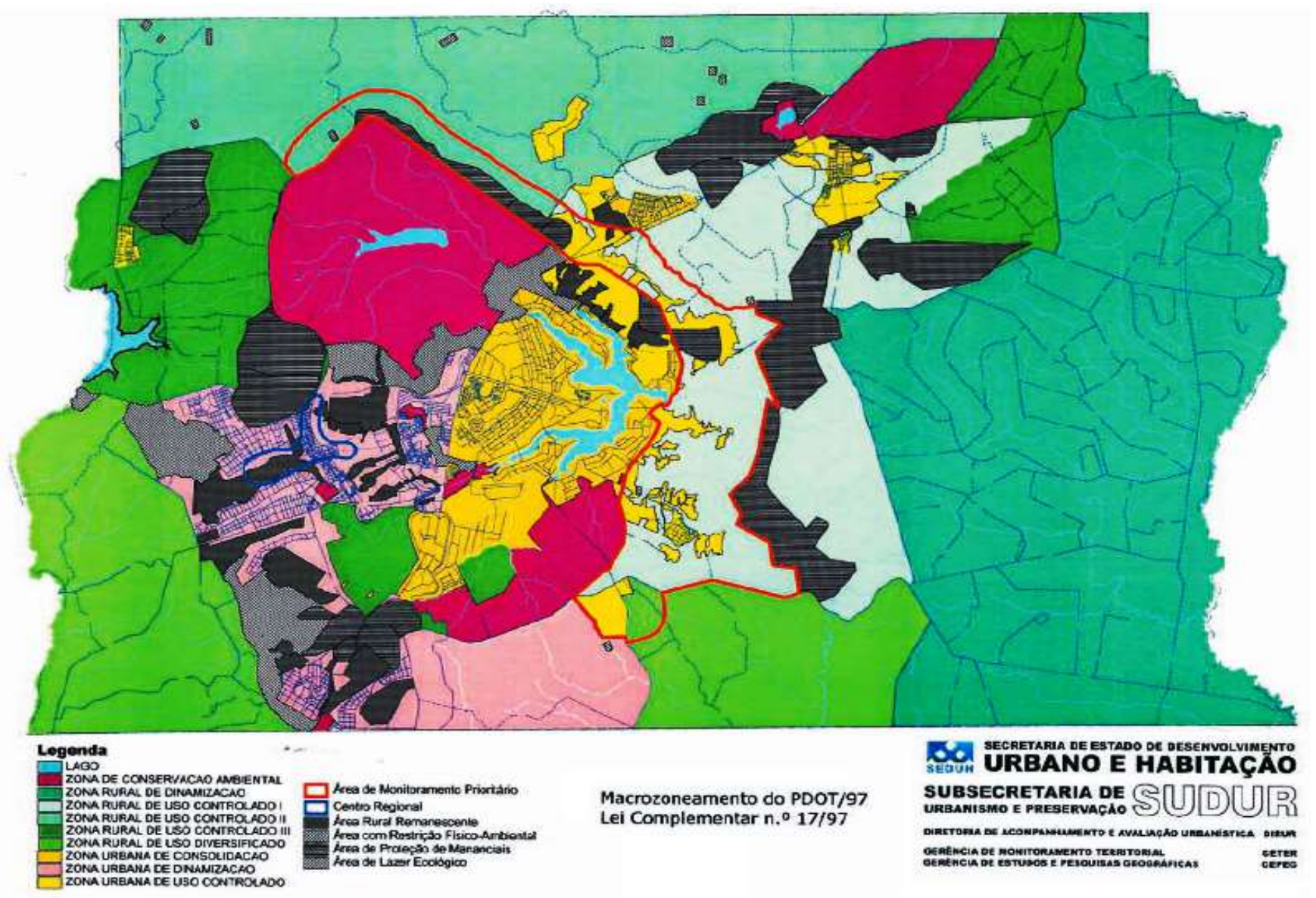

Fonte: COSTA, Graciete Guerra. As regiões Administrativas do Distrito Federal de 1960 a 2011. 


\section{APÊNDICE G}

Mapa do Plano Diretor de Ordenamento Territorial do DF/2009.

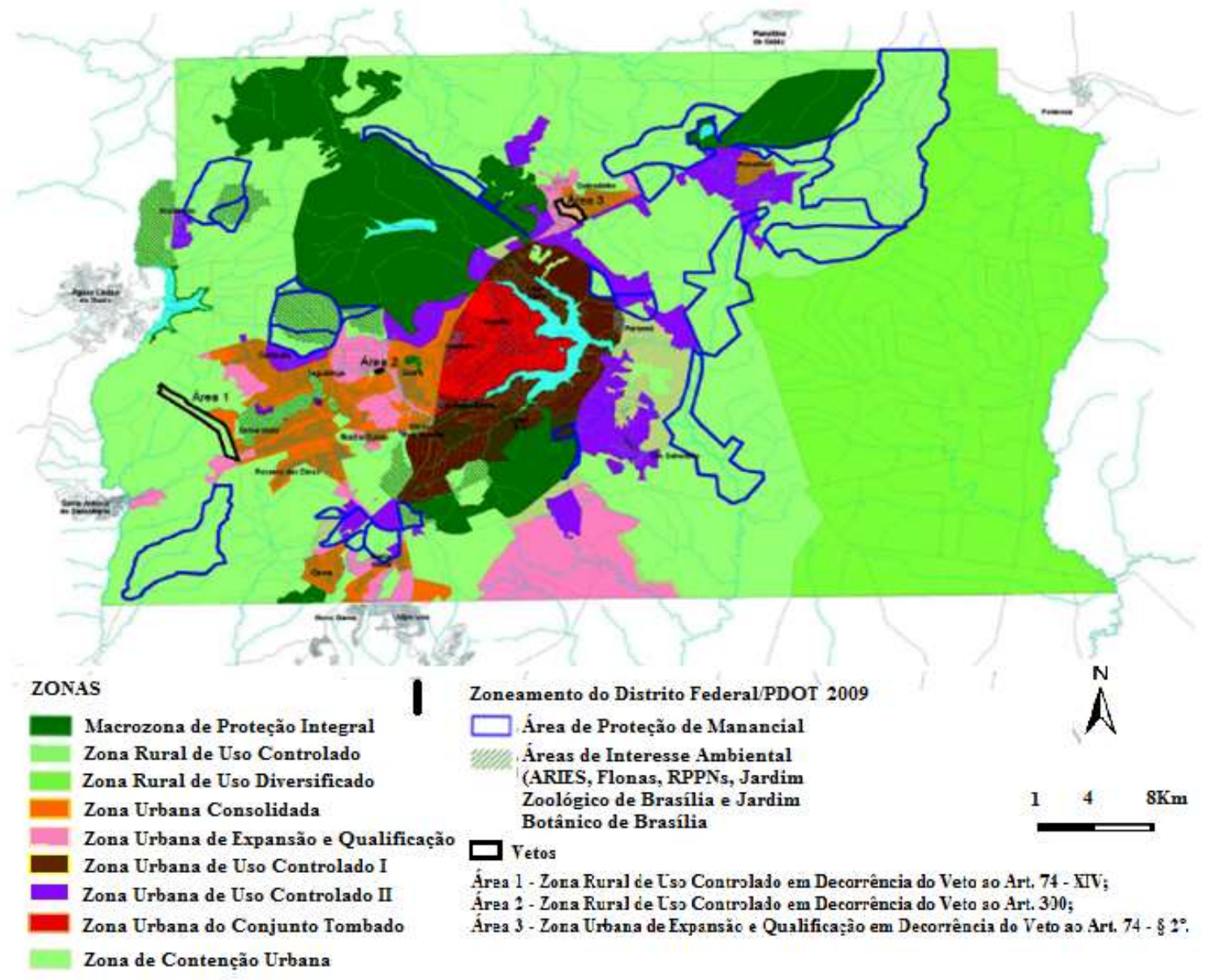

Fonte: Diário Oficial do Distrito Federal - Suplemento A no 80, segunda-feira, 27 de abril de 2009, página 26. Anexo I - Mapa 1A - Zoneamento do Distrito Federal - PDOT/2009.

Adaptado: Gilney de Araújo Costa. 


\section{APÊNDICE H}

Mapa do Plano Diretor de Ordenamento Territorial do DF/2012.

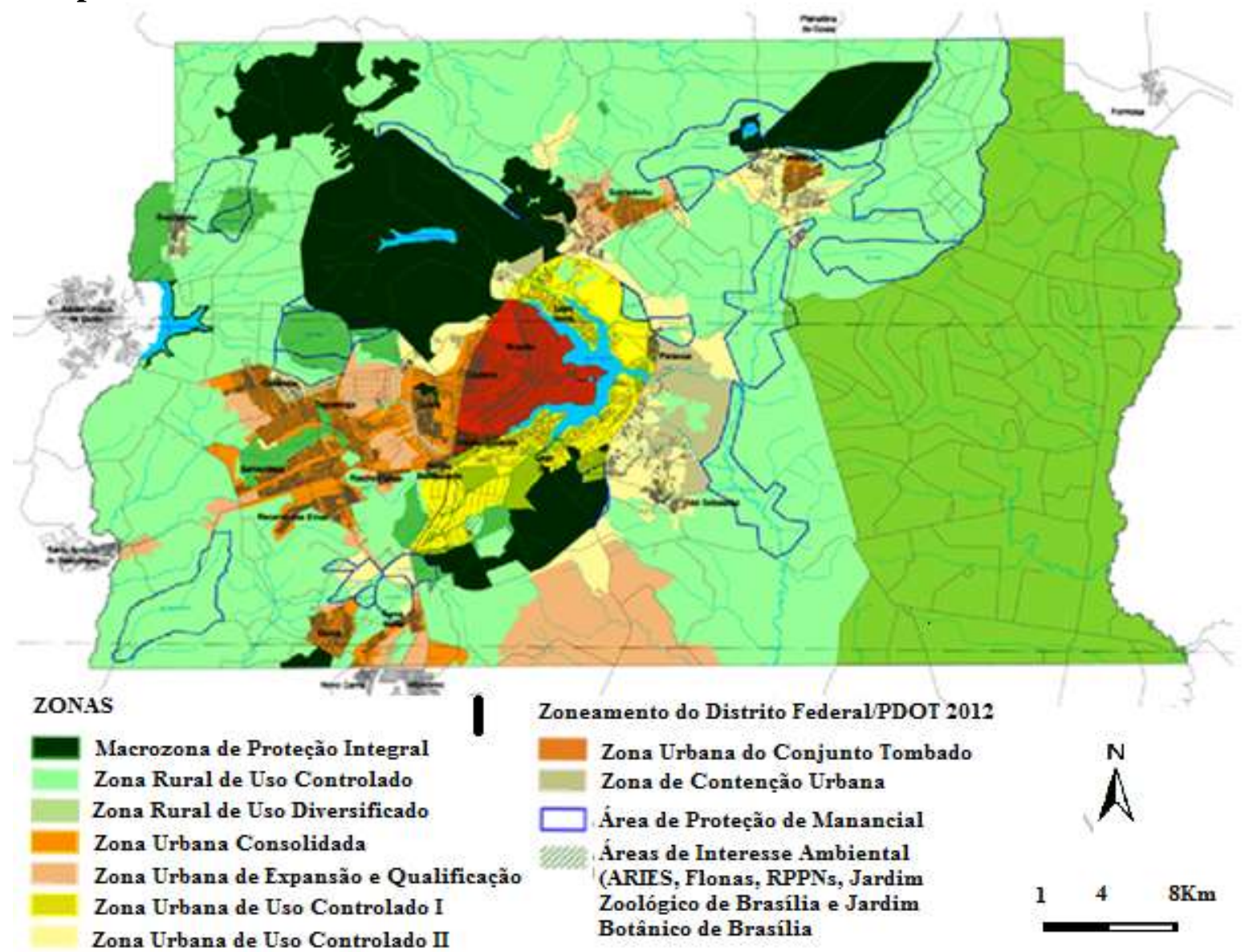

Fonte: Diário Oficial do Distrito Federal nº 211, quarta-feira, 17 de outubro de 2012, página 6 Anexo I -Mapa 1A - Zoneamento do Distrito Federal - PDOT, 2012. Adaptado: Gilney de Araújo Costa. 


\section{APÊNDICE I}

\section{Anexo do Mapa de Estratégias de Regularização Fundiária e de Ofertas de Áreas Habitacionais no DF.}

Àrea de Regularização de Interesse Específico - ARINE em Setor Habitacional

\begin{tabular}{|c|c|}
\hline 1.E-1 & Área de Reg. Interesse Específico - ARINE Torto I. \\
\hline 1.E-2 & Área de Reg. Interesse Específico - ARINE Torto II. \\
\hline 1.E-3 & Área de Reg. Interesse Específico - ARINE Torto III. \\
\hline 2.E-1 & Área de Reg. Interesse Especifico - ARINE Ponte de Terra. \\
\hline 3.E-1 & Área de Reg. Interesse Específico - ARINE Vicente Pires I. \\
\hline 3.E-2 & Área de Reg. Interesse Específico - ARINE Vicente Pires II. \\
\hline 4.E-1 & Área de Reg. Interesse Específico - ARINE Arniqueira. \\
\hline 5.E-1 & Área de Reg. Interesse Específico - ARINE Primavera. \\
\hline 6.E-1 & Área de Reg. Interesse Específico - ARINE Itapoã. \\
\hline 7.E-1 & Área de Reg. Interesse Específico - ARINE Região dos Lagos. \\
\hline 8.E-1 & Área de Reg. Interesse Específico - ARINE Boa Vista I. \\
\hline 8.E-2 & Área de Reg. Interesse Específico - ARINE Boa Vista II. \\
\hline 8.E-3 & Área de Reg. Interesse Específico - ARINE Boa Vista III. \\
\hline 8.E-4 & de Reg. Interesse Específico - ARINE Boa Vista IV. \\
\hline 9.E-1 & Área de Reg. Interesse Específico - ARINE Grande Colorado. \\
\hline 10.E-1 & Área de Reg. Interesse Específico - ARINE Contagem I. \\
\hline 10.E-2 & Área de Reg. Interesse Específico - ARINE Contagem II. \\
\hline 11.E-1 & Área de Reg. Interesse Específico - ARINE Mansões Sobradinho. \\
\hline 13.E-1 & Área de Reg. Interesse Específico - ARINE Alto da Boa Vista. \\
\hline 19.E-1 & Área de Reg. Interesse Específico - ARINE Altiplano Leste I. \\
\hline 19.E-2 & Área de Reg. Interesse Específico - ARINE Altiplano Leste II. \\
\hline 20.E-1 & Área de Reg. Interesse Específico - ARINE São Bartolomeu. \\
\hline 22.E-1 & Área de Reg. Interesse Específico - ARINE Bernardo Sayão. \\
\hline 25.E-1 & Área de Reg. Interesse Específico - ARINE Tororó I. \\
\hline 25.E-2 & Área de Reg. Interesse Específico - ARINE Tororó II. \\
\hline 25.E-3 & Área de Reg. Interesse Específico - ARINE Tororó III. \\
\hline 25.E-4 & Área de Reg. Interesse Específico - ARINE Tororó IV. \\
\hline 25.E-5 & Área de Reg. Interesse Específico - ARINE Tororó V. \\
\hline 25.E-6 & Área de Reg. Interesse Específico - ARINE Tororó VI. \\
\hline 26.E-1 & Área de Reg. Interesse Específico - ARINE Jardim Botânico. \\
\hline 27.E-1 & Área de Reg. Interesse Específico - ARINE Estrada do Sol I. \\
\hline 27.E-2 & Área de Reg. Interesse Específico - ARINE Estrada do Sol II. \\
\hline 27.E-3 & Área de Reg. Interesse Específico - ARINE Estrada do Sol III. \\
\hline 28.E-1 & Área de Reg. Interesse Específico - ARINE Dom Bosco I. \\
\hline 28.E-2 & Área de Reg. Interesse Específico - ARINE Dom Bosco II. \\
\hline 29.E-1 & Área de Reg. Interesse Específico - ARINE Taquari I. \\
\hline 29.E-2 & Área de Reg. Interesse Específico - ARINE Taquari II. \\
\hline 29.E-3 & Área de Reg. Interesse Específico - ARINE Taquari III. \\
\hline \multicolumn{2}{|r|}{ Áreas de Regularização de Interesse Específico fora de Setor Habitacional } \\
\hline $\mathbf{E}-1$ & Área de Reg. Interesse Específico - ARINE Mansões Paraíso. \\
\hline $\mathbf{E}-2$ & Área de Reg. Interesse Específico - ARINE La Font. \\
\hline $\mathbf{E}-\mathbf{3}$ & Área de Reg. Interesse Específico - ARINE Mônaco. \\
\hline E - 4 & Área de Reg. Interesse Específico - ARINE Sucupira. \\
\hline $\mathbf{E}-\mathbf{5}$ & Área de Reg. Interesse Específico - ARINE Privê Lago Norte. \\
\hline E - 6 & Área de Reg. Interesse Específico - ARINE Porto Seguro. \\
\hline
\end{tabular}




\begin{tabular}{|c|c|}
\hline \multicolumn{2}{|c|}{ Área de Regularização de Interesse Social - ARIS em Setor Habitacional } \\
\hline 1.S-1 & Área de Reg. Interesse Social - ARIS Torto. \\
\hline 3.S-1 & Área de Reg. Interesse Social - ARIS Vicente Pires. \\
\hline 5.S-1 & Área de Reg. Interesse Social - ARIS Primavera. \\
\hline 6.S-1 & Área de Reg. Interesse Social - ARIS Itapoã. \\
\hline 11.S-1 & Área de Reg. Interesse Social - ARIS Mansões Sobradinho I. \\
\hline 11.S-2 & Área de Reg. Interesse Social - ARIS Mansões Sobradinho II. \\
\hline 12.S-1 & Área de Reg. Interesse Social - ARIS Fercal I. \\
\hline 12.S-2 & Área de Reg. Interesse Social - ARIS Fercal II. \\
\hline 12.S-3 & Área de Reg. Interesse Social - ARIS Fercal III. \\
\hline 12.S-4 & Área de Reg. Interesse Social - ARIS Fercal IV (Queima Lençol). \\
\hline 14.S-1 & Área de Reg. Interesse Social - ARIS Nova Colina I. \\
\hline 14.S-2 & Área de Reg. Interesse Social - ARIS Nova Colina II. \\
\hline 15.S-1 & Área de Reg. Interesse Social - ARIS Mestre D’Armas I. \\
\hline 15.S-2 & Área de Reg. Interesse Social - ARIS Mestre D’Armas II. \\
\hline 15.S-3 & Área de Reg. Interesse Social - ARIS Mestre D’Armas III. \\
\hline 16.S-1 & Área de Reg. Interesse Social - ARIS Arapoanga I. \\
\hline 16.S-2 & Área de Reg. Interesse Social - ARIS Arapoanga II. \\
\hline 17.S-1 & Área de Reg. Interesse Social - ARIS Aprodarmas I. \\
\hline 17.S-2 & Área de Reg. Interesse Social - ARIS Aprodarmas II. \\
\hline 17.S-3 & Área de Reg. Interesse Social - ARIS Aprodarmas III. \\
\hline 18.S-1 & Área de Reg. Interesse Social - ARIS Vale do Amanhecer. \\
\hline 21.S-1 & Área de Reg. Interesse Social - ARIS Sol Nascente. \\
\hline 23.S-1 & Área de Reg. Interesse Social - ARIS Água Quente. \\
\hline 24.S-1 & Área de Reg. Interesse Social - ARIS Ribeirão. \\
\hline 27.S-1 & Área de Reg. Interesse Social - ARIS Estrada do Sol. \\
\hline \multicolumn{2}{|c|}{ Áreas de Regularização de Interesse Social - ARIS fora de Setor Habitacional } \\
\hline S-1 & Área de Reg. Interesse Social - ARIS Expansão Vila São José. \\
\hline S - 2 & Área de Reg. Interesse Social - ARIS Buritis. \\
\hline S - 3 & Área de Reg. Interesse Social - ARIS DNOCS. \\
\hline S-4 & Área de Reg. Interesse Social - ARIS Vila Cauhy. \\
\hline S - 5 & Área de Reg. Interesse Social - ARIS Pôr do Sol. \\
\hline S- 6 & Área de Reg. Interesse Social - ARIS Privê Ceilândia. \\
\hline S - 7 & Área de Reg. Interesse Social - ARIS Estrutural. \\
\hline S - 8 & Área de Reg. Interesse Social - ARIS Vida Nova. \\
\hline S - 9 & Área de Reg. Interesse Social - ARIS Céu Azul. \\
\hline S - 10 & Área de Reg. Interesse Social - ARIS Morro da Cruz. \\
\hline S - 11 & Área de Reg. Interesse Social - ARIS CAUB I. \\
\hline S - 12 & Área de Reg. Interesse Social - ARIS CAUB II. \\
\hline S - 13 & Área de Reg. Interesse Social - ARIS QNP 22 e 24 Ceilândia. \\
\hline S - 14 & Área de Reg. Interesse Social - ARIS QNR 05 Ceilândia. \\
\hline
\end{tabular}




\section{APÊNDICE J}

\section{$1^{\text {a }}$ Audiência Pública sobre os Becos de Brazlândia.}

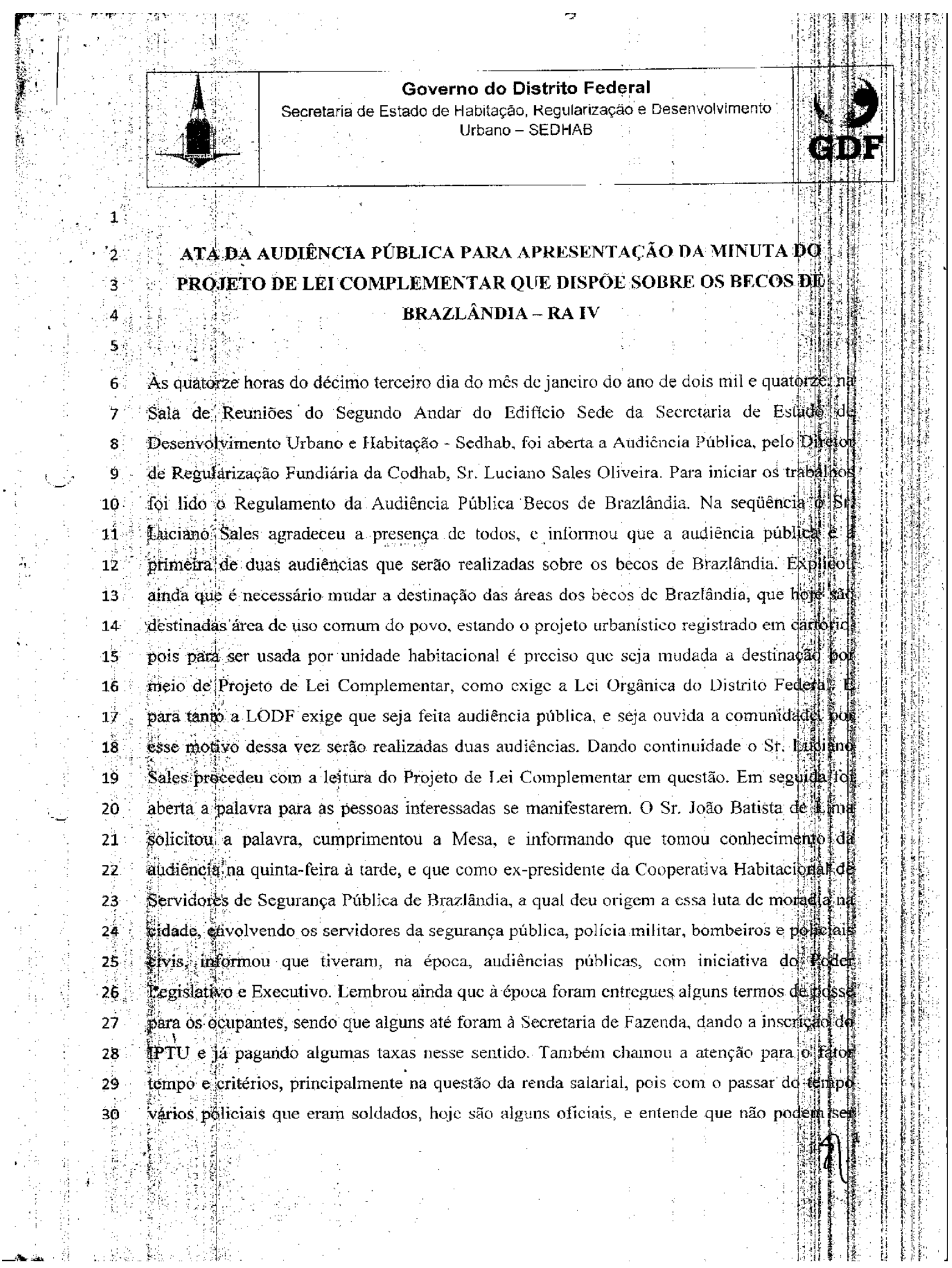




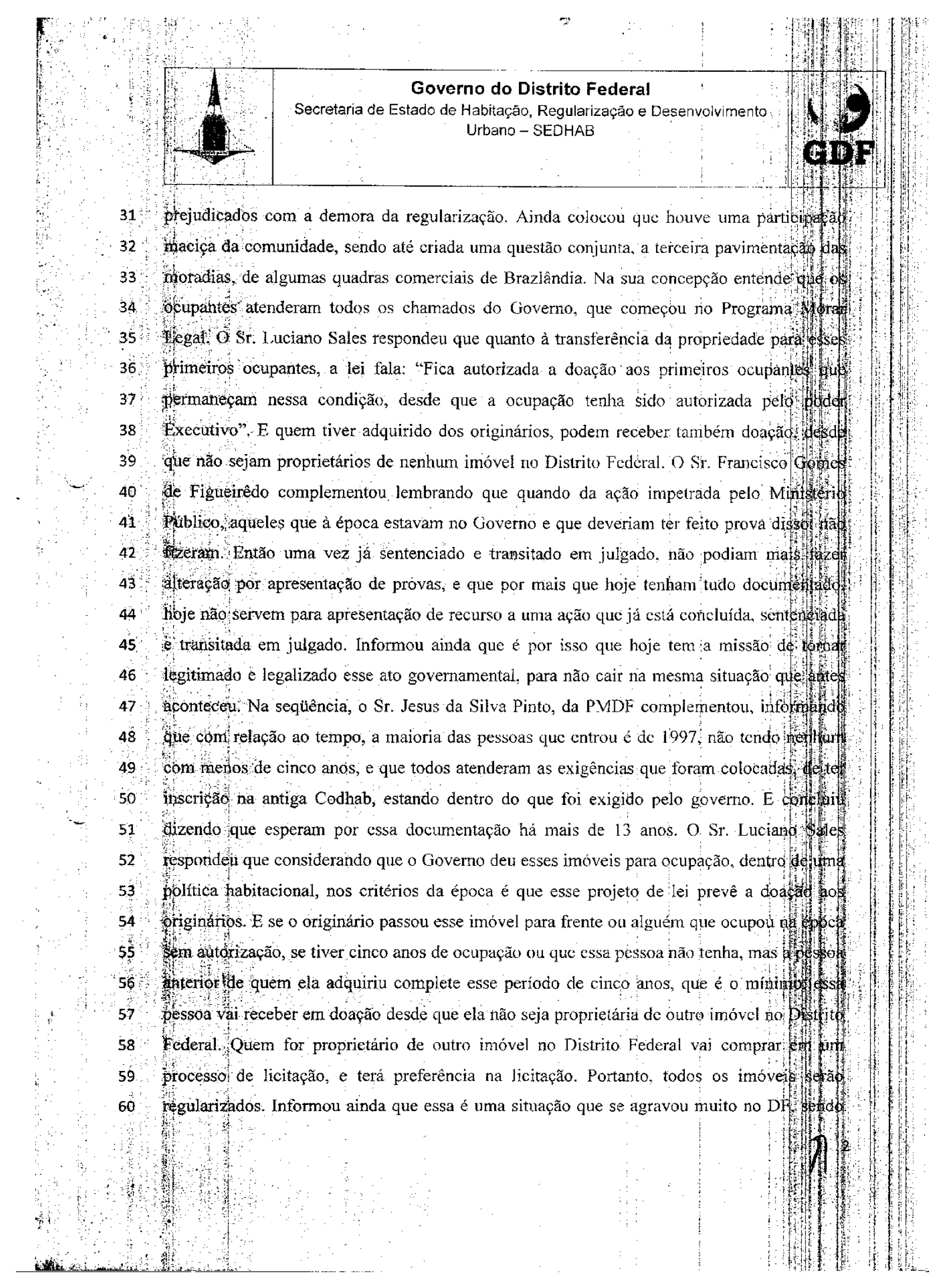




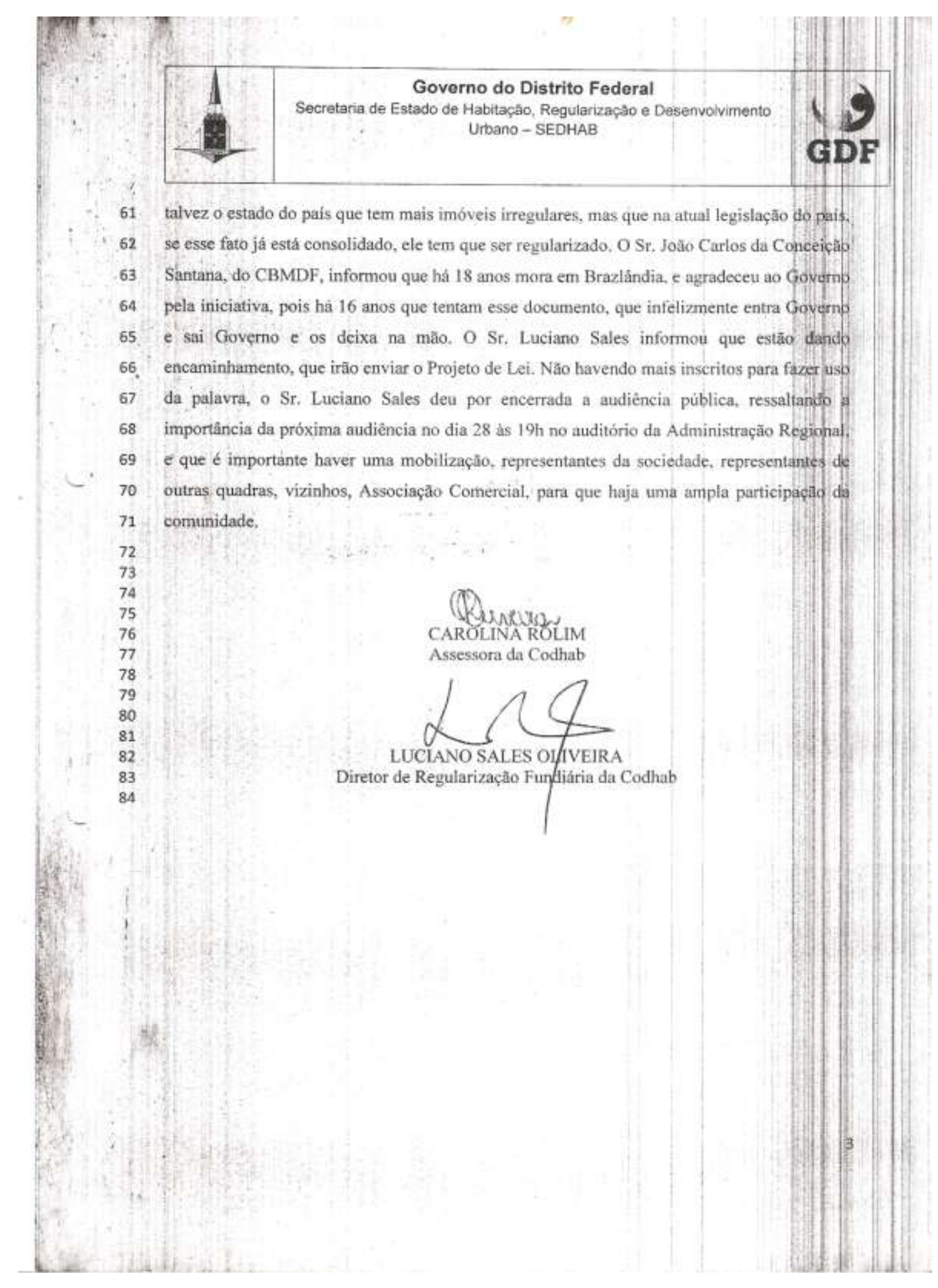




\section{APÊNDICE L}

\section{$2^{a}$ Audiência Pública sobre os Becos de Brazlândia.}

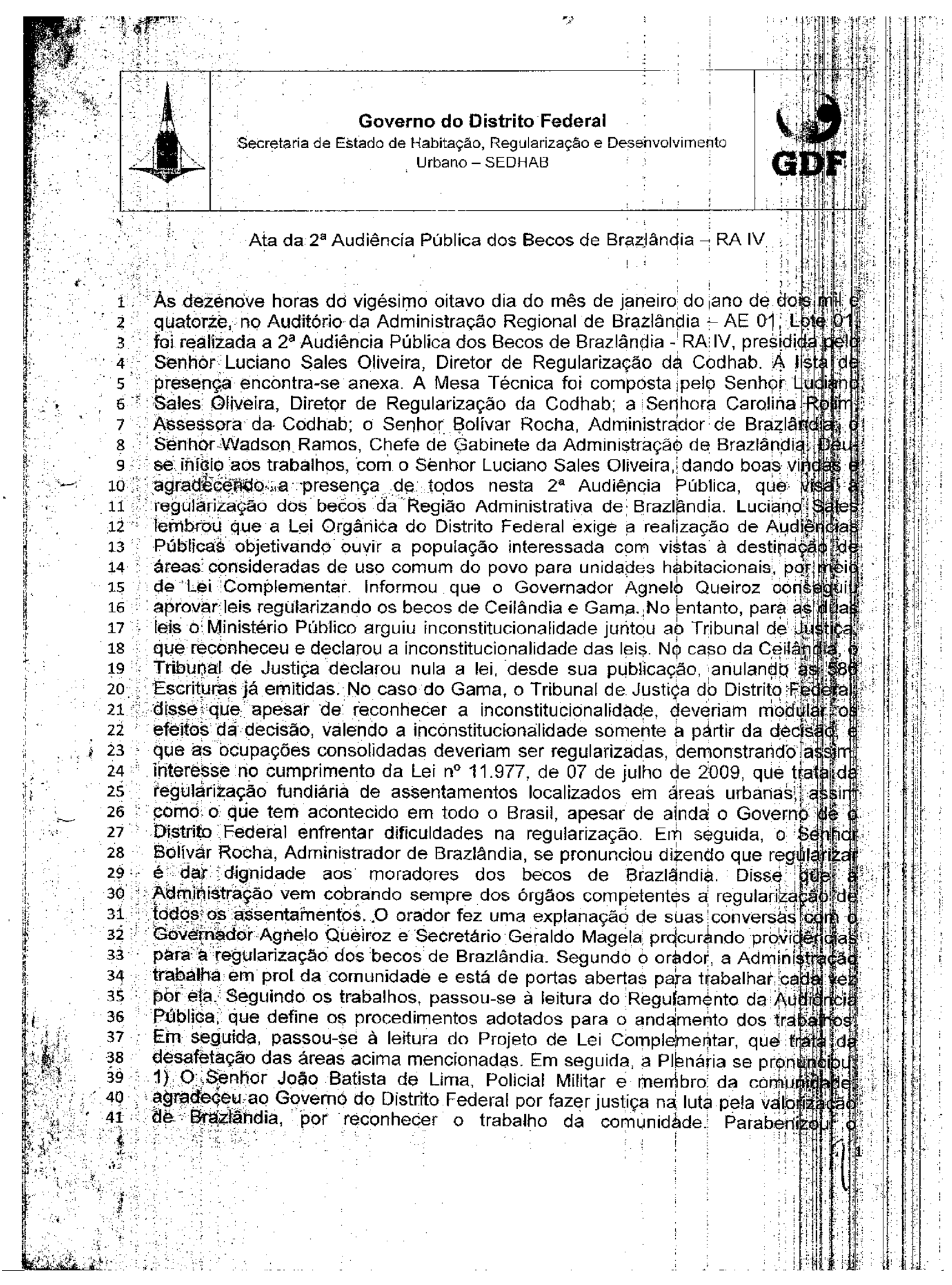




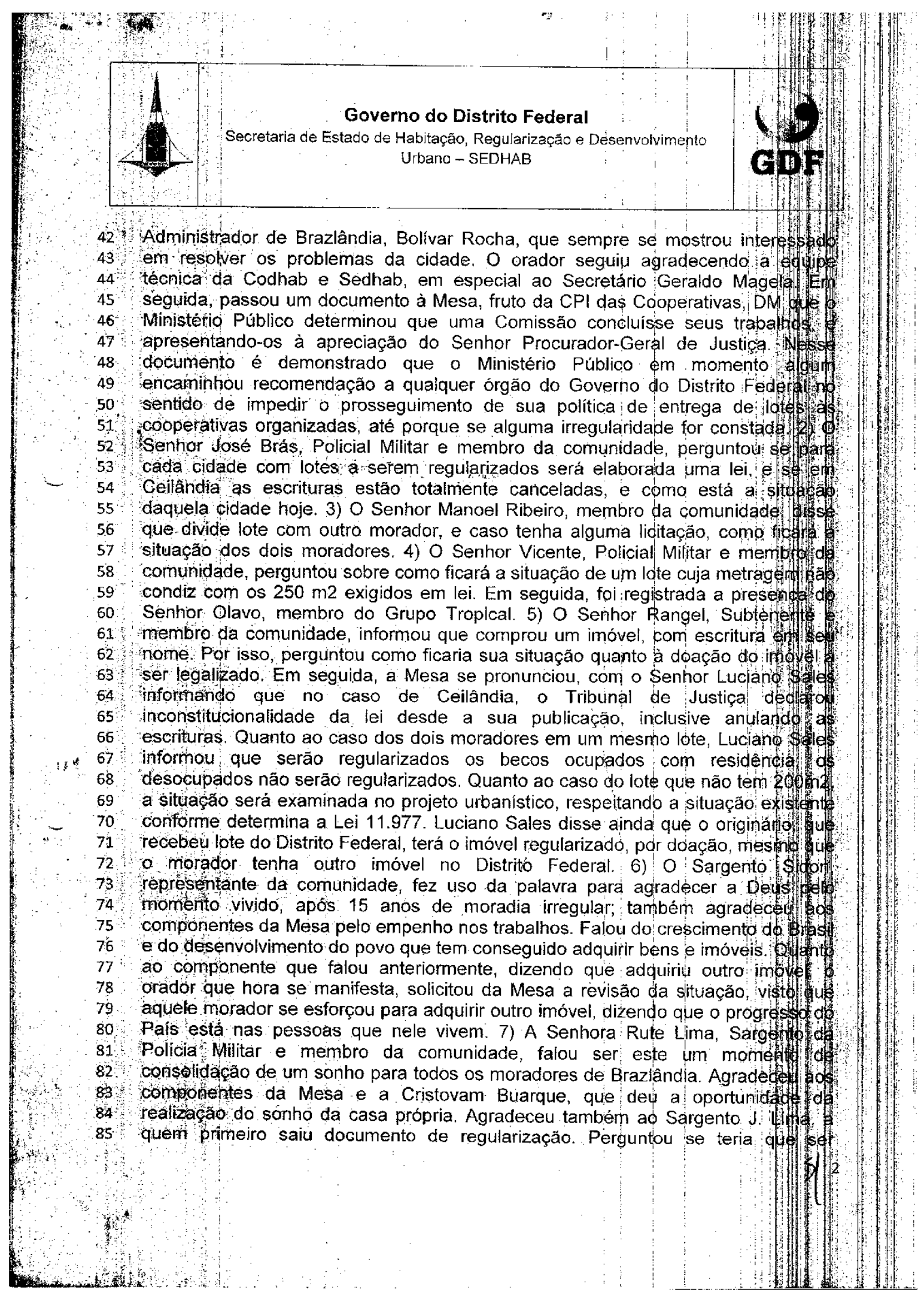




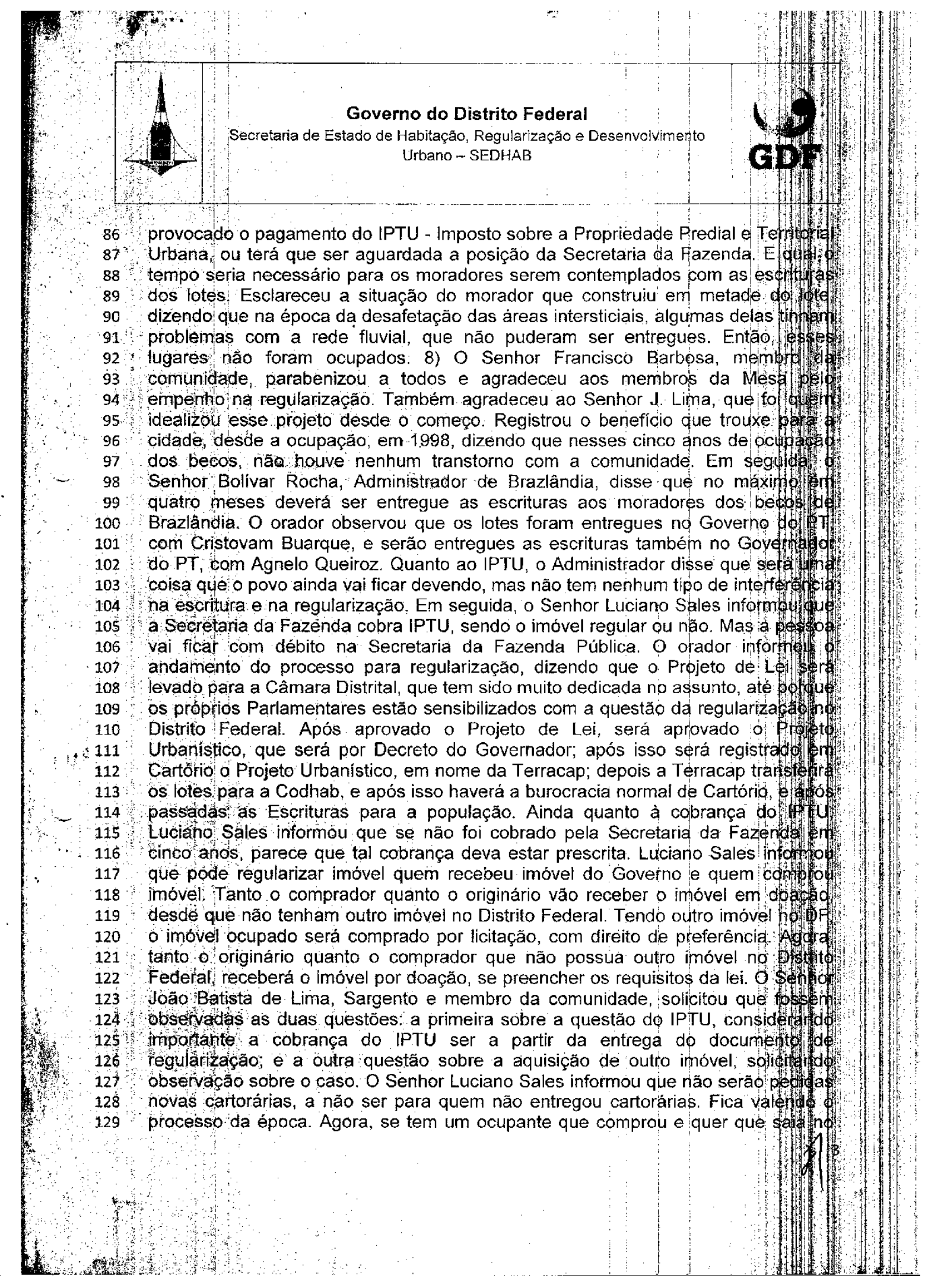




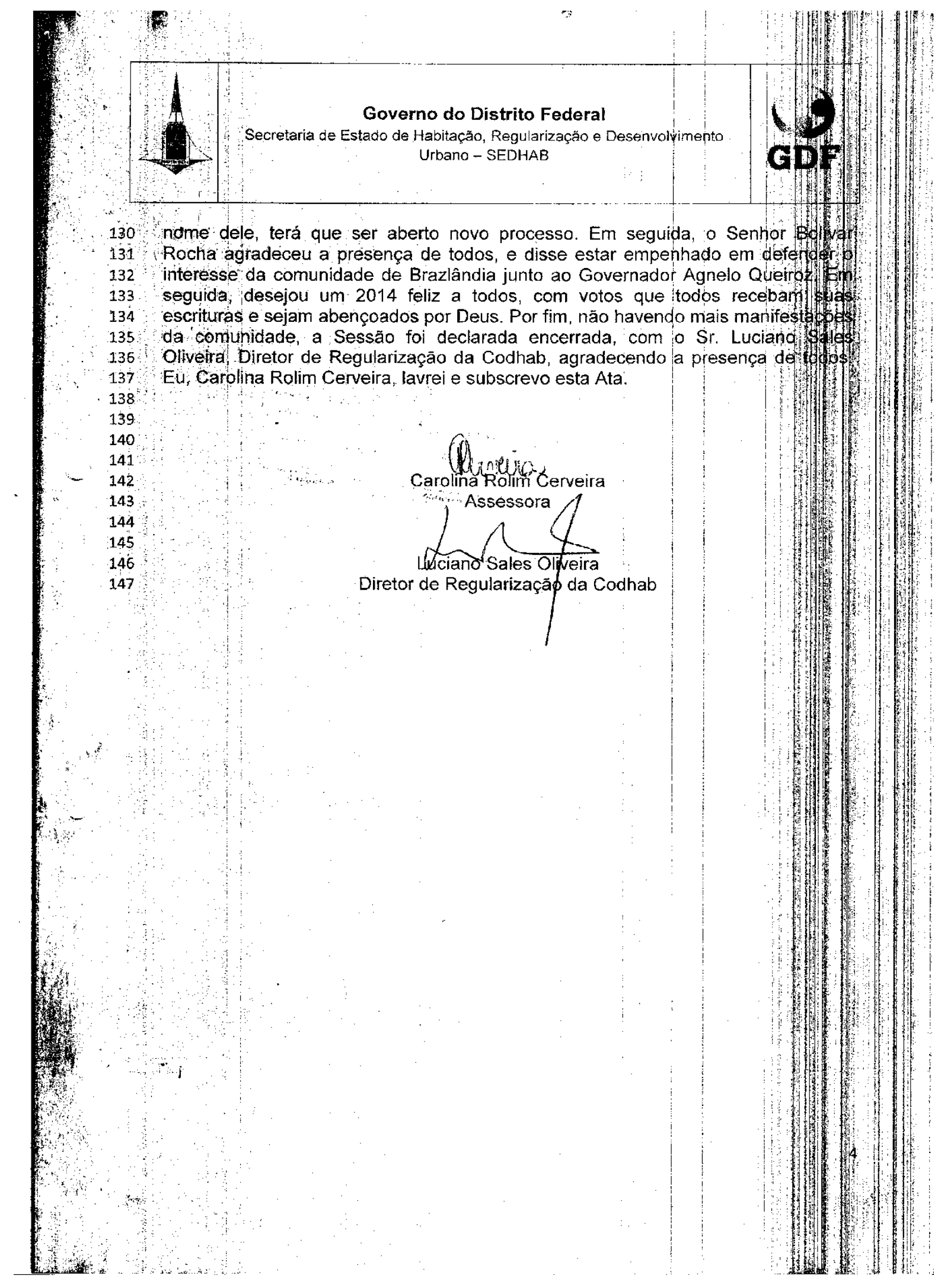

